Sheila Fernandes Pimenta e Oliveira

Vânia de Fátima Martino

Genaro Alvarenga Fonseca

Maria Madalena Gracioli (org.)

\title{
Inclusão e Diversidade: múltiplos olhares
}

Coleção Educação e Educandos
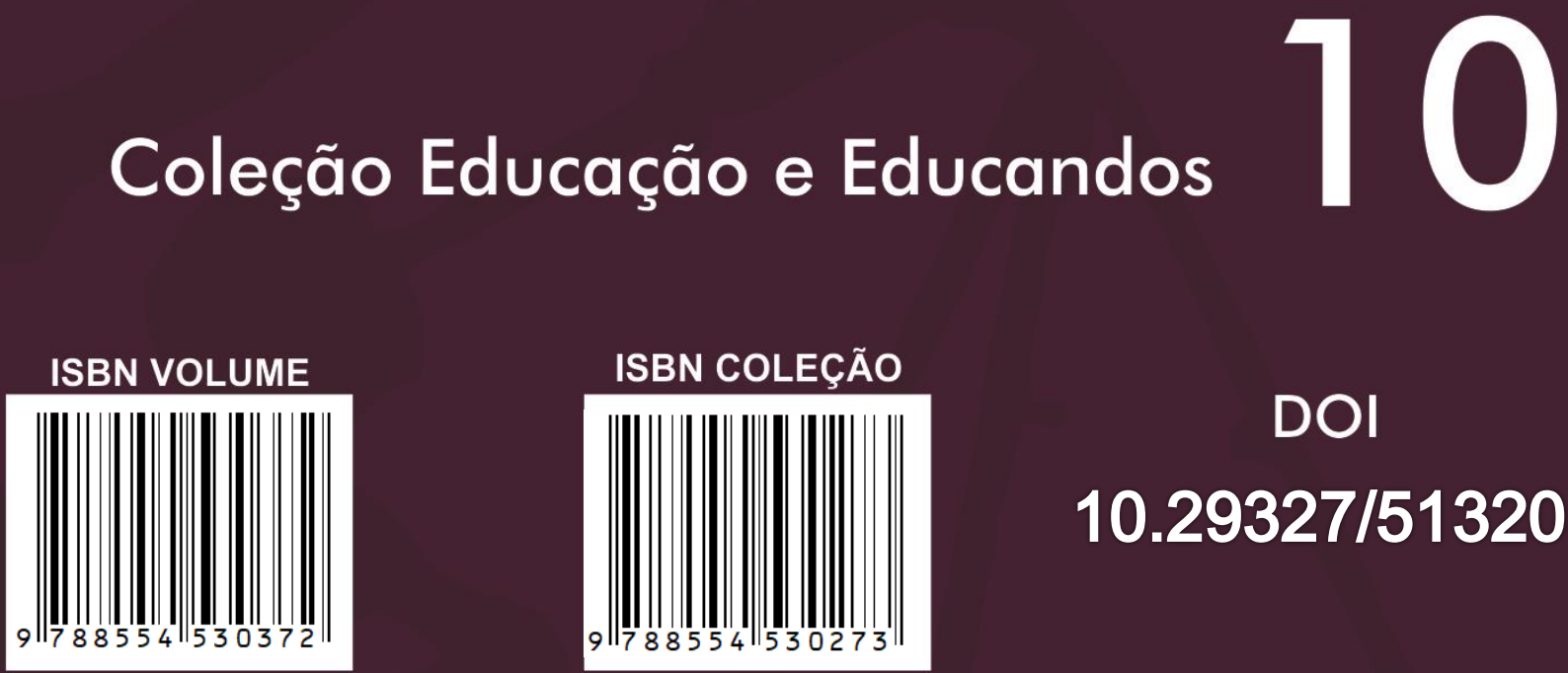

DOI

$10.29327 / 513205$ 


\section{INCLUSÃO E DIVERSIDADE: múltiplos olhares}


Sheila Fernandes Pimenta e Oliveira

Vânia de Fátima Martino Genaro Alvarenga Fonseca

Tatiana Noronha de Souza (org.)

INCLUSÃO E DIVERSIDADE: múltiplos olhares

ISBN 978-85-5453-037-2

FRANCA

Uni-FACEF/UNESP

2019 


\section{Comissão Científica}

Alessandra David (Centro Universitário Moura Lacerda)

Ana Lúcia Furquim Campos-Toscano (Uni-FACEF)

Célia Maria David (UNESP)

Fernando Silva Ribeiro (Universidade Estadual de Goiás)

Genaro Alvarenga Fonseca (UNESP)

Hilda Maria Gonçalves da Silva (UNESP)

Joana Correa Goulart (Universidade Estadual de Goiás)

Karina de Melo Conte (Centro Universitário Claretiano)

Karina Elizabeth Serrazes (Centro Universitário Claretiano)

Lucinda de Fátima Maria Coelho Rodrigues (Uni-FACEF)

Lucimary Bernabé Pedrosa de Andrade (FFCL)

Márcia Pereira da Silva (UNESP)

Maria Eloísa de Souza Ivan (Uni-FACEF)

Maria Madalena Graciloi (FFCL)

Maria Sílvia Pereira Rodrigues Alves Barbosa ((Uni-FACEF)

Pricila Bertanha (Centro Universitário Claretiano)

Sheila Fernandes Pimenta e Oliveira (Uni-FACEF)

Sílvia Regina Viel (Uni-FACEF)

Sílvio Carvalho Neto (Uni-FACEF)

Vânia de Fátima Martino (UNESP)

Tatiana Noronha de Souza (UNESP)

Welton Roberto Silva (Uni-FACEF)

\section{Conselho Editorial}

Ana Cláudia da Silva (UnB)

Antônio Carlos Petean (UFU)

Daniela Melaré Vieira Barros - Universidade Aberta / Portugal

Danilo Seithi Kato (UFTM)

Genaro Alvarenga Fonseca (UNESP)

Sheila Fernandes Pimenta e Oliveira ((Uni-FACEF)

Sílvio Carvalho Neto (Uni-FACEF)

Teise de Oliveira Guaranha Garcia - FFCLRP / USP

Vânia de Fátima Martino (UNESP) 
(C) 2019 dos autores

Direitos de publicação Uni-FACEF

www.unifacef.com.br

Coleção: Educação e Educandos, v.10. 


\begin{tabular}{|c|c|c|c|}
\hline \multirow[t]{4}{*}{ O51i } & \multicolumn{3}{|c|}{$\begin{array}{l}\text { Oliveira, Sheila Fernandes Pimenta e (Org.) } \\
\text { Inclusão e diversidade: múltiplos olhares. / Sheila Fernandes Pimenta e } \\
\text { Oliveira; Vânia de Fátima Martino; Genaro Alvarenga Fonseca; Maria } \\
\text { Madalena Gracioli (Org.). - Franca: Uni-FACEF; Unesp/Franca; } 2019 . \\
\text { (Coleção: Educação e educandos, v.10) } \\
\text { 172p.; il. }\end{array}$} \\
\hline & \multicolumn{3}{|c|}{$\begin{array}{l}\text { ISBN Coleção: 978-85-5453-027-3 } \\
\text { ISBN Volume: 978-85-5453-037-2 } \\
\text { DOI 10.29327/513205 }\end{array}$} \\
\hline & \multirow[t]{2}{*}{$\begin{array}{cc}\text { 1.Educação } & \text { - Pesquisa. } \\
\text { diversidade. } & \text { I.T. }\end{array}$} & 2. Inclusão escolar. & 3.Educação e \\
\hline & & & CDD 370 \\
\hline
\end{tabular}

TODOS OS DIREITOS RESERVADOS.

É proibida a reprodução total ou parcial, de qualquer forma ou por qualquer meio. A violação dos direitos de autor (lei no. 9.610/98) é crime estabelecido pelo artigo 184 do código Penal. Todo o conteúdo apresentado neste livro é de responsabilidade exclusiva de seus autores.

Editora Uni-FACEF Centro Universitário Municipal de Franca Associada à ABEC - Associação Brasileira de Editores Científicos 


\section{PREFÁCIO}

Este livro, que é parte da coleção Educação e Educandos, está organizado em 15 capítulos, que tecem importantes reflexões sobre a inclusão e a diversidade na escola e na sociedade. Os capítulos resultam das pesquisas apresentadas no VII Simpósio de Educação e IV Encontro Internacional de Políticas Públicas em Educação, discutem a necessidade, a viabilidade, a operacionalidade da inclusão e debatem sobre a diversidade em suas diferentes esferas e nuances.

Atualmente, é imperativo refletir e dialogar a respeito de práticas segregacionistas e preconceituosas, que estão presentes nos espaços educacionais, em ambientes de trabalho, assim como em espaços sociais e virtuais, compreender que o termo diversidade assume um aspecto positivo como luta em favor dos direitos de pessoas e/ou setores excluídos ou marginalizados socialmente devido à sua condição socioeconômica, de gênero, de raça, de idade, pelo não domínio de tecnologias, por possuir alguma deficiência ou síndrome, pela aparência física, ou simplesmente por não se encaixar aos padrões culturalmente tidos como normais.

A vida em sociedade pressupõe o reconhecimento da diversidade, das multiculturas, a aceitação das diferenças como recursos e não como problemas, a reestruturação das culturas, das políticas públicas e das práticas cotidianas de modo a responder à diversidade, acreditar que a inclusão e o respeito à diversidade na escola é uma parte importante da inclusão na sociedade, e considerar que uma sociedade justa se faz com equidade.

É, nesse sentido, que os textos que compõem este volume trazem a público o resultado de profícuas reflexões e análises em torno de estudos realizados pelos autores acerca da temática da inclusão e da diversidade, na certeza de que o conhecimento só se amplia quando divulgado, e só é legitimado quando compartilhado. Por sua vez, o Uni-FACEF e a UNESP - Franca - cumprem o compromisso com a sociedade ao divulgar e partilhar conhecimento publicando esta importante coleção.

A seriedade no tratamento das pesquisas e a multiplicidade de pontos de vistas proporcionadas pelos diferentes estudos garantem a utilidade desta obra a todos que têm interesse pelas questões da inclusão e da diversidade. Convido, 
assim, o leitor a mergulhar nas páginas seguintes com aguçado espírito de curiosidade e a conhecer na pluralidade temática os importantes aportes teóricometodológicos e empíricos, e a sensibilidade das contribuições dos autores com suas profundas reflexões que buscam quebrar o paradigma da inclusão e da diferenciação como exceção, mas sim, como princípio transformador que desvela a premência de uma sociedade mais tolerante, inclusiva, menos preconceituosa e mais justa.

Prof ${ }^{a}$. Dra ${ }^{\mathrm{a}}$. Maria Madalena Gracioli 


\section{SUMÁRIO}

A EDUCAÇÃO PARA PESSOAS COM DEFICIÊNCIA VISUAL NO BRASIL 9

A HISTÓRIA DA EDUCAÇÃO: A relevância da Educação Especial - APAEs na atual conjuntura Social.

AS DIFICULDADES DE INSERÇÃO DO ADOLESCENTE AUTOR DE ATO INFRACIONAL NA POLÍTICA DA EDUCAÇÃO: Obstáculos cotidianos.

DIVERSIDADE, DEFICIÊNCIA E ESCOLA: A educação inclusiva como questão de direitos humanos e cidadania

GERONTECNOLOGIA: O uso da tecnologia e a qualidade de vida de pessoas idosas.....

HISTÓRIA DA EDUCAÇÃO ESPECIAL NO BRASIL .......................................67

IDOSO E PALHAÇO UMA RELAÇÃO DE EMPODERAMENTO

INTERPRETAÇÕES ACERCA DA ESCRAVIDÃO NO BRASIL E SEUS DESDOBRAMENTOS CONTEMPORÂNEOS NA EDUCAÇÃO.

O DESAFIO DA EDUCAÇÃO INCLUSIVA NA ADOLESCÊNCIA.

O ENSINO DO DIREITO COMO MÉTODO DE PROMOÇÃO DA CULTURA DA

PAZ

OS ARGUMENTOS JURÍDICOS A FAVOR DO DEBATE SOBRE GÊNERO NAS ESCOLAS

PERCEPÇÕES DE ALUNOS UNIVERSITÁRIOS SOBRE DIVERSIDADE DE GÊNERO E INTOLERÂNCIA DENTRO DO CAMPUS 123

POLÍTICA DE ACESSO E PERMANÊNCIA DE PESSOAS COM DEFICIÊNCIA VISUAL NA UNIVERSIDADE

POVOS INDÍGENAS E O ENSINO DE HISTÓRIA: Prática pedagógica em uma sala do $6^{\circ}$ ano do Ensino Fundamental.

PRINCIPAIS POLÍTICAS PÚBLICAS NACIONAIS VOLTADAS PARA A INCLUSÃO EDUCACIONAL DO DEFICIENTE MENTAL NO BRASIL: Uma revisão. 156

ÍNDICE 172 


\title{
A EDUCAÇÃO PARA PESSOAS COM DEFICIÊNCIA VISUAL NO BRASIL
}

\author{
CAETANO, Jaqueline Silva \\ Graduada em Geografia - UEMG \\ jaquelinecaetanotrab@gmail.com \\ GIMENES, Priscila Alvarenga Cardoso \\ Doutora em Educação Especial - UEMG \\ priscilagimenes1@gmail.com
}

\section{INTRODUÇÃO}

A inclusão de alunos com deficiências nas escolas regulares tem se efetivado no país desde os anos 2000, entretanto, diversas as ações destinadas estes alunos são foram desenvolvidas no Brasil ao longo do século passado.

Com enfoque na deficiência visual, o presente trabalho, faz parte das ações do Projeto de Extensão da UEMG PAEx/UEMG, com o tema: Cartografia tátil: recurso pedagógico para o ensino de Geografia às pessoas com deficiência visual teve como objetivo discutir sobre os principais marcos que balizaram 0 desenvolvimento de práticas educativas e recursos específicos para o aluno com deficiência e os principais desafios enfrentados pela escola atualmente para a inclusão de alunos com deficiência intelectual. Para tanto, foi empreendida uma pesquisa bibliográfica, contando com a contribuição de Mendes (2010), Jannuzzi (2004), Mazzotta (2001), entre outros.

Refletindo sobre um pretérito não muito distante, permeando entre as esferas da educação e da legislação brasileira, introduzimos o histórico e a evolução das diretrizes sobre a pessoa com deficiência visual no que diz respeito a seu processo de escolarização, tendo atrelado a essa discussão o histórico e desenvolvimento da educação especial e inclusiva, sendo componente crucial para a integração das pessoas com deficiência na escola regular, como também na sociedade.

\section{ASPECTOS HISTÓRICOS DO PROCESSO DE INCLUSÃO SOCIAL E EDUCACIONAL DA PESSOA COM DEFICIÊNCIA VISUAL}




\subsection{Brasil Colônia}

A educação especial começa a ser esboçada em uma época estruturada em pré-conceitos, onde médicos e pedagogos enxergavam novas possibilidades para as pessoas com deficiência, mas "Apesar de algumas escassas experiências inovadoras desde o século XVI, o cuidado foi meramente custodial, e a institucionalização em asilos e manicômios foi a principal resposta social para tratamento dos considerados desviantes" (MENDES, 2006, p.387).

Neste período acreditava-se que pessoas consideradas diferentes seriam melhor amparadas em instituições. "Foi uma fase de segregação, justificada pela crença de que a pessoa diferente seria mais bem cuidada e protegida se confinada em ambiente separado, também para proteger a sociedade dos “anormais" (MENDES, 2006, p.387). De fato, uma concepção errônea e puramente sentenciosa, pois enclausurar indivíduos considerados diferentes não legítima o verdadeiro significado de cuidar e proteger.

Nesse sentido, historicamente o Brasil expressou soluções pouco adequadas para as pessoas com deficiência, a desatenção não sucedeu apenas no campo assistencial e médico, mas também no educacional, o que evidência um desamparo integralizado. Referente a escolarização, "analisando o período colonial [...], prevaleceu neste período o descaso do poder público, não apenas em relação à educação de indivíduos com deficiências, mas também quanto à educação popular de modo geral." (MENDES, 2010, p.94).

Visando o desenvolvimento do histórico educacional no Brasil que se inicia no ano de 1835, no período Regencial, a governança do Brasil estava sob a regência do político conservador e padre Diego Antônio Feijó, no qual fazia parte do chamado Partido Moderado. Feijó foi o responsável em mandar arquivar o projeto de lei do Deputado Cornélio Ferreira França, o primeiro projeto em que objetivava-se oferecer ensino para cegos e surdos, na capital do Império e nas capitais das províncias (MELLO e MACHADO, 2017).

A segunda tentativa de se instituir ensino para pessoas com deficiência visual no Brasil sucedeu pelo jovem José Alvares de Azevedo, no qual fora direcionado a estudar em Paris, no Instituto Imperial dos Jovens Cegos. Após retornar da França, vinculou-se ao movimento pela educação no Brasil, assim escrevendo artigos em jornais e ministrando aulas particulares. Foi pelo encargo de professor que Azevedo se tornou conhecido do médico da Imperial Câmera, o Dr. José Francisco Xavier Sigaud, que logo ficou empolgado com as ideias do jovem para criação de uma instituição para cegos (INSTITUTO BENJAMIN CONSTANT, 1995).

Assim, o Dr. Sigaud apresentou Azevedo ao Barão de Rio Bonito e solicitou que levasse o jovem à presença do Imperador D. Pedro II, que ao vê-lo redigindo em Braille, teria dito: "A cegueira não é mais uma desgraça", palavras a que, aliás, o Dr. Sigaud mencionaria em seu discurso na ocasião da instalação do 
Instituto (INSTITUTO BENJAMIN CONSTANT, 1995). Dessa maneira, os primeiros indícios de uma atenção voltada à educação para pessoas com deficiência visual, segundo Masini (1993, p.62):

A primeira preocupação, no Brasil, com a educação de deficientes, apareceu a 12 de setembro de 1854. O imperador Pedro II baixou o Decreto Imperial $\mathrm{n}^{\circ}$, 1.428, criando o Imperial Instituto de Meninos Cegos - marco inicial da educação de deficientes visuais no Brasil e América Latina.

Com a instauração do decreto pelo Imperador Pedro II se inicia a educação para cegos no Brasil, porém de forma não tão bem planejada, e até mesmo improvisada, pois mesmo com o decreto para constituição do instituto sancionado pelo Imperador, a câmera dos deputados negou o montante orçamentário para seu funcionamento. Com a verba negada para o instituto, apenas, em 1855, autoriza-se o montante do orçamento em um período de dois anos (1855-1856), por meio do decreto ํㅜ 1.683, de 28 de novembro de 1855" (MELLO e MACHADO, 2017).

Com a liberação da verba os indícios de uma reestruturação educacional surgem em meio aos transtornos da época. Logo no final do século XIX a educação no país apresentava-se de forma desoladora e miserável, pois havia uma escassez relacionada a quantidade de escolas para a população carente, resultando em índices cada vez maiores de analfabetismo, onde a problemática em questão também dificultava o ensino para as pessoas com deficiência (CORRÊA, 2010).

\subsection{Século $X X$}

Com a proclamação da república do Brasil que se sucedeu em 1889, não houve mudanças significativas na educação. conforme mencionam Xavier et al. (1994 apud Effting, 2008, p.17):

A constituição republicana (1891) extinguiu o critério de renda para o voto, mas nem dessa forma houve interesse do poder público em expandir o sistema de ensino. Outro desinteresse pela educação foi a continuação da descentralização do sistema escolar elementar. Novamente foi afirmado na Constituição de 1891, o discurso de manter o federalismo, com responsabilidade na educação superior e a autonomia dos Estados na Educação do ensino secundário. Ficou evidente dessa forma, a precária condição da escola primária nas diversas regiões do pais durante o período Imperial.

Após este período, já "durante as duas primeiras décadas do século XX o país vivenciava uma fase de estruturação da república e emergiram discrepâncias regionais mais acentuadas, além de uma série de transformações político-sociais" 
MENDES (2010, p.95). O Brasil passava pelo processo de urbanização, registrando altas taxas de crescimento e do PIB - Produto Interno Bruto. Essas mudanças impulsionaram o pais e resultaram em mudanças no panorama da educação.

Nesse sentido, e esfera educacional ainda se desenvolvia e "o acesso à educação para portadores de deficiências vai sendo muito lentamente conquistado, na medida em que se ampliaram as oportunidades educacionais para a população em geral" (MENDES, 2006, p.95). Ainda faltava recursos para a educação e a população em sua grande maioria não estudava.

Era necessário implantar soluções educacionais quando o analfabetismo já encontrava em torno dos $80 \%$, assim a escola primária pública surge entre as décadas de vinte e trinta (ARANHA, 1989). A direção que a educação tomava estivera naquele momento em pauta para a discussão dos vários setores organizados da sociedade, "entretanto, tanto as classes quanto as escolas especiais somente iriam proliferar como modalidade alternativa às instituições residenciais depois das duas guerras mundiais" (MENDES, 2006, p.95).

Já entre a década de 1930 a 1940, algumas modificações ocorreram nas diretrizes da educação nacional, podendo ser citados: a evolução do ensino primário e secundário, a constituição do ministério da educação e saúde, a criação da Universidade de São Paulo, aumento das escolas técnicas e a reestruturação de algumas escolas de magistério (MENDES, 2010). As alterações ocorridas entre essas duas décadas evidenciam reformas formais e substanciais na educação escolar do Brasil, junto a Constituição de 1934, que estabeleceu a premência de um plano nacional de educação.

Porém, no desenvolver da década de 1950, a falta de serviços e a falta de atenção do poder público fizeram surgir movimentos comunitários que resultaram na constituição de redes de escolas especiais filantrópicas, privadas e sem fim lucrativo para aqueles que sempre permaneceram excluídos das escolas comuns (JANNUZZI, 2004). Nessa etapa do desenvolvimento o governo disponibilizava de ambientes especializados, não incorporando à escola regular as pessoas com deficiências e em relação as fundações conforme Mello e Machado, (2017, p.34):

Na década de 1950, em São Paulo, surge a Fundação para o Livro do Cego no Brasil, mais tarde denominada fundação Dorina Nowill, que através de muita luta política consegue do Governo Vargas, pela Lei 2.268, de 14 de julho 1954, a isenção de impostos e taxas federais para referida instituição, que passa editar livros em Braille.

Conseguinte dessa iniciativa, Dorina Nowill se estabelece adjacente ao Instituto Benjamin Constant, dando abertura a outro caminho para a produção de materiais e livros, assim também favorecendo e auxiliando para o desenvolvimento da alfabetização de pessoas com deficiência visual no Brasil.

Outro acontecimento muito importante nesse período foi a criação da primeira escola especial da Associação de Pais e Amigos dos Excepcionais (APAE), 
em 1954 localizada no Rio de Janeiro, devido a influência do casal de norteamericanos Beatrice Bemis e George Bemis. O casal Bemis influenciaram, pois eram integrantes da National Association for Retarded Children e da atual National Association for Retarded Citizens (NARCH), que de passagem ao Brasil buscavam incentivar a formação de associações deste gênero (MENDES, 2010).

Passados dois anos, em 1956 foi fundada a Campanha Nacional de Educação e Reabilitação dos Deficientes Visuais, que passou a ser chamada na década de 1960 de Campanha Nacional de Educação dos Cegos - C.N.E.C (FRANCO e DIAS, 2007), que passou a oferecer maiores oportunidades de atendimento educacional as pessoas com deficiência visual.

Assim, de acordo com Art. 1ํㅡㄹ instituído pelo Decreto no 48.252, a Campanha Nacional de Educação dos Cegos (C.N.E.C.) passou a ser diretamente subordinada ao Ministro de Estado da Educação e Cultura (BRASIL, 1960). Essa campanha desenvolvia atividades para treinamento e especialização de docentes e técnicos na área da educação e também para a reabilitação de pessoas com deficiência visual. Incentivava também a elaboração e manutenção de recursos educacionais, como: livros, equipamentos, material para escrita, entre outros (MAZZOTTA, 2001).

Durante as décadas de 1960 e 1970 se sucedeu maior avanço em relação aos serviços destinados à reabilitação, em função do maior incentivo e apoio governamental (FRANCO e DIAS, 2007). Tendo em vista o amparo do governo, a Lei 4.024 de Diretrizes e Bases, promulgada em 20 de dezembro de 1961, gerou o Conselho Federal de Educação, apresentando nela a expressão "educação de excepcionais" presente em dois artigos, o art.88 que visa a integração de classes especiais e o art.89 que impulsiona a criação de instituições filantrópicas (como as APAES, entre outras (MENDES, 2010).

Com a lei 4.024 de Diretrizes e Bases o atendimento educacional ás pessoas com deficiência passou a ser firmado pela LDB da Educação Nacional, Lei $n^{\circ}$. 74.024/61, que determina o direito dos "excepcionais" à educação, preferencialmente dentro do sistema geral de ensino, a escola regular (MENDES, 2010). Passados três anos, já em 1964, houve a instauração do regime militar, período em que, segundo Mendes (2010, p.100):

\footnotetext{
[...] instaurou a ditadura, no qual foram acentuados o processo de desnacionalização da economia, a concentração de renda, a repressão das manifestações políticas, o êxodo rural, os problemas urbanos e o empobrecimento da população. As reformas educacionais deste período atingiram o ensino superior resultando na perda da autonomia da universidade, sem, entretanto, eliminar o dualismo escolar. Neste período ocorreu um processo até então sem precedentes de privatização do ensino, agora já sob a mentalidade empresarial.
}

Com a ditadura, como corrobora a citação a cima, houve reformas educacionais em todas as esferas do ensino. Direcionando para a educação básica, 
- Estado reduziu a verba voltada para educação, e a quantia que ainda era repassada fora insuficiente, interferindo nas estruturas físicas das escolas e nos profissionais que nela trabalhavam. Além de professores sem formação, os salários junto às condições de trabalho dos docentes passaram pelo processo de deterioração (ASSIS, 2012).

Assim, o Decreto no 63.258, de 19 de setembro de 1968, possui efetividade sobre o projeto especial prioritário do programa de planejamento estratégico para o desenvolvimento, denominado "Operação-Escola", onde agora há obrigatoriedade dos estudos dos 7 aos 14 anos (BRASIL, 1968). A também a Coordenação de Estudos Legislativos - CEDI em 1969, que delibera:

\begin{abstract}
Dispõe sobre o tratamento excepcional para os alunos portadores das afecções que indica. Os ministros da marinha de guerra, do exército e da aeronáutica, militar, usando das atribuições que lhes confere 0 artigo $3^{\circ}$ do ato institucional $\mathrm{n}^{\circ}$ 16, de 14 de outubro de 1969 , combinado com o $\S 1^{\circ}$. do artigo $2^{\circ}$ do ato institucional $\mathrm{n}^{\circ}$ 5, de 13 de dezembro de 1968, e considerando que a constituição assegura a todos o direito à educação; considerando que condições de saúde nem sempre permitem frequência do educando à escola, na proporção mínima exigida em lei, embora se encontrando o aluno em condições de aprendizagem; considerando que a legislação admite, de um lado, o regime excepcional de classes especiais, de outro, o da equivalência de cursos e estudos, bem como o da educação peculiar dos excepcionais;
\end{abstract}

É interessante observar que o decreto descrito acima foi redigido por ministros militares, que dão ênfase a educação e que ela é para todos, assim ratificando pela primeira vez, por meio de decreto o direito em exercício às classes especiais no Brasil e de sua equidade. Mensura-se que a educação especial surge em meio ao regime autoritário (MELLO e MACHADO, 2017).

Nessas circunstancias, permeamos na década de 70, período onde sucederam muitos avanços, esse relacionado a quantidade de números de serviços de assistência. Assim, "a rede de serviços era basicamente composta por classes especiais nas escolas regulares (74\%), a maioria delas em escolas estaduais $(71 \%)$ " (MENDES, 2010, p.100). Ainda trabalhando com dados, a autora citada acima menciona que (80\%) ainda era composto por instituições especializadas, assim sendo um quarto dos serviços e ainda hegemonicamente de natureza privada.

Na legislação também se observa uma reestruturação nos parâmetros da educação, onde se reafirma no Art. 9 da Lei de Diretrizes e Bases para o Ensino de $1^{\circ}$ e $2^{\circ}$ graus - de 1971 - Lei 5692/71, Brasil (1971):

Os alunos que apresentem deficiências físicas ou mentais, os que se encontrem em atraso considerável quanto à idade regular de matrícula e os superdotados deverão receber tratamento especial, de acordo com as normas fixadas pelos competentes Conselhos de Educação. 
Com essa lei, passou-se a oferecer tratamento especial à alunos com as devidas necessidades, matriculados no ensino entre as fases de $1^{\circ}$ e $2^{\circ}$ grau. Assim pode se notar que Nunes e Ferreira, (1994) apud Mendes (2010, p.100) citam as mudanças devido a reafirmação da lei de diretrizes e base de 1971:

[...] pode-se observar na década de setenta a necessidade de definir as
bases legais e técnico-administrativas para o desenvolvimento da educação
especial no país. Em termos de legislação a necessidade deste tipo de
serviço já constara da Lei 4.024 de 1961 , Artigo 88 , e foi reafirmada na Lei
5.602 de 1971 , a segunda Lei de Diretrizes e Bases da Educação Nacional
de 1971 , feita no contexto de ditadura e de interesses econômicos
mundiais, que alterou a estrutura do ensino criando novos níveis, entre eles
o ensino de $1^{\circ}$ grau (8 séries anuais e obrigatório dos 7 os 14 anos) e
ensino de $2^{\circ}$ grau (duração mínima de 3 anos e de técnica obrigatória). A
regulamentação da matéria com pareceres do Conselho Federal de
Educação foi feita entre 1972 e 1974 , muito embora o atendimento
preconizado nestes documentos evidenciem uma abordagem mais
terapêutica do que educacional.

Assim, no ano de 1976 podemos constatar a criação do Sistema Nacional de Previdência e Assistência Social (Sinpas) e seu aparato de cunho financeiro denominado Fundo de Previdência e Assistência Social (FPAS), que juntou e centralizou as várias instituições encarregadas pelos programas de assistência social, inserindo dentre elas a Legião Brasileira de Assistência (LBA), que era encarregada pelo financiamento das instituições filantrópicas privadas (MENDES, 2010).

No ano seguinte, em 1977 foi instituído o Ministério da Previdência e Assistência Social, em seguida iriam aparecer as portarias interministeriais (educação, previdência e ação social), normatizando as diretrizes para atuação no campo do atendimento às pessoas com deficiência proporcionando um atendimento integrado, incorporado por ações complementares de médica-psico-sociais e de educação especial, determinando e definindo sua clientela, obtendo sobre o diagnóstico o encaminhamento, a supervisão e o controle, aumentando o enfoque assistencialista sobrepondo-o ao educacional do atendimento (MENDES, 2010).

Já no fim da década de 70 são instituídos os primeiros cursos para a formação de professores no ramo da educação especial em nível de terceiro grau e os primeiros programas de pós-graduação a empregarem na área de educação especial (MENDES, 2010).

De acordo com Santos (1995, p. 24), "até os anos 80 a integração desenvolveu-se dentro de um contexto histórico em que pesaram questões como igualdade e direito de oportunidades". Os anos 80 foram marcados pelo I Encontro Nacional de Entidades de Pessoas Deficientes, fortalecendo e consolidando muitas entidades que representavam as categorias de pessoas com deficiências (MENDES, 2010). 
No ano de 1981 foi instituído pela Organização das Nações Unidas (ONU) o Ano e a Década da Pessoa Portadora de Deficiência, assim ampliando os horizontes, no que diz respeito aos meios de comunicação, para uma maior conscientização da sociedade (SILVA, 1986, CANZIANI,1994, SANTOS, 1995) apud FRANCO E DIAS, (2005). Os instrumentos designados para difusão de informação passavam a ter uma nova concepção, eles também tinham como finalidade a conscientização sobre a pessoa com deficiência na sociedade.

No ano de 1985 o Cenesp é condicionado a Secretaria de Educação Especial e é fundado um comitê nacional para delinear política de ação conjunta, designada a aperfeiçoar educação especial, assim integrando na sociedade pessoas com deficiências, problemas de conduta e superdotados (MENDES, 2010). No ano seguinte, "[...] é lançado o "Plano Nacional de Ação Conjunta" e instituída, a Coordenadoria para a Integração da Pessoa Portadora de Deficiência (Corde), dispondo sobre a atuação da Administração Federal, no que concerne às pessoas com deficiência" (MENDES, 2010, p.101).

Segundo o Ministério da Educação Secretaria de Educação Especial (2010), dos marcos político-legais da educação especial na perspectiva da educação inclusiva no Brasil, teve em 1988 um aparato legal importantíssimo para as diretrizes da educação: A Constituição Federal de 1988, que estabelece:

\begin{abstract}
A Constituição Federal de 1988 traz como um dos seus objetivos fundamentais "promover o bem de todos, sem preconceitos de origem, raça, sexo, cor, idade e quaisquer outras formas de discriminação" (art. $3^{\circ}$, inciso IV). Define, no artigo 205, a educação como um direito de todos, garantindo o pleno desenvolvimento da pessoa, o exercício da cidadania e a qualificação para o trabalho. No seu artigo 206, inciso I, estabelece a "igualdade de condições de acesso e permanência na escola" como um dos princípios para o ensino e garante, como dever do Estado, a oferta do atendimento educacional especializado, preferencialmente na rede regular de ensino (art. 208).
\end{abstract}

Assim, a Constituição Federal de 1988 reafirma de forma mais reformulada e ampla os marcos político-legais da educação especial direcionados a educação inclusiva, garantindo a igualdade entre todos e os direitos das pessoas com deficiência na escola regular, assegurando seu acesso e permanência, certificando assim 0 atendimento especializado nas redes de ensino regulares públicos.

"A década de 90 sinalizou mudanças consideráveis na política educacional brasileira, resultando em novas perspectivas para a política de Educação Especial" (JÚNIOR e TOSTA, 2012, p.5). Esse período foi marcado por um conjunto de leis publicados no Brasil para serem aplicados no âmbito educacional, e ainda houve a realização de conferências e declarações internacionais, que redimensionaram a formulação de políticas públicas relacionadas à educação da pessoa com deficiência no país (JÚNIOR e TOSTA, 2012). 
O Ministério da Educação em parceira com a Secretaria De Educação Continuada, Alfabetização, Diversidade e Inclusão - SECADI, redigiu a Política Nacional de Educação Especial na Perspectiva da Educação Inclusiva, que menciona (BRASIL, 2008, s.p):

O Estatuto da Criança e do Adolescente - ECA, Lei no 8.069/90, no artigo 55 , reforça os dispositivos legais supracitados ao determinar que "os pais ou responsáveis têm a obrigação de matricular seus filhos ou pupilos na rede regular de ensino". Também nessa década, documentos como a Declaração Mundial de Educação para Todos (1990) e a Declaração de Salamanca (1994) passam a influenciar a formulação das políticas públicas da educação inclusiva.

O estatuto citado acima passa a determinar que os responsáveis têm o dever de inscrever crianças e jovens no ensino regular e menciona também documentos como a Declaração Mundial de Educação para Todos (1990) e a Declaração de Salamanca (1994) que influenciaram novas políticas públicas associadas a educação inclusiva. Esses documentos, respectivamente, na Conferência de Jomtien, em 1990, realizou o plano de ação para satisfazer as necessidades básicas de aprendizagem, assim como em 1994, que estabeleceu sobre os princípios, políticas e práticas na área das necessidades educativas especiais.

De acordo com Sassaki (1998, p.09), "a sociedade inclusiva começou a ser construída a partir de algumas experiências de inserção social de pessoas com deficiência, ainda na década de oitenta". O autor citado (1998, p.42) ainda complementa que "a inclusão social, portanto, é um processo que contribui para a construção de um novo tipo de sociedade através de transformações, pequenas e grandes, nos ambientes físicos e na mentalidade de todas as pessoas [...]".

Desse modo, a inclusão social coadjuva na estruturação de uma nova sociedade, por meio de modificações em espaços físicos e na concepção dos indivíduos, que introduz o progresso dos moldes do corpo social estabelecidos. A Política Nacional de Educação Especial publicada em 1994 (BRASIL, 1994, p.17) descreve a educação especial como:

[...] um processo que visa promover o desenvolvimento das potencialidades de pessoas portadoras de deficiências, condutas típicas ou de altas habilidades, e que abrange os diferentes níveis e graus do sistema de ensino. Fundamenta-se em referenciais teóricos e práticos compatíveis com as necessidades específicas de seu alunado. O processo deve ser integral, fluindo desde a estimulação essencial até os graus superiores de ensino.

Com a Declaração de Salamanca e Linha de Ação sobre Necessidades Educativas Especiais, é proclamando que as escolas regulares devem elaborar meios e concepções mais eficientes para se eliminar atitudes discriminatórias de todos as naturezas, no qual destaca o trecho (BRASIL, 1997, p. 17 e 18): 
O princípio fundamental desta Linha de Ação é de que as escolas devem acolher todas as crianças, independentemente de suas condições físicas, intelectuais, sociais, emocionais, linguísticas ou outras. Devem acolher crianças com deficiência e crianças bem dotadas; crianças que vivem nas ruas e que trabalham; crianças de populações distantes ou nômades; crianças de minorias linguísticas, étnicos ou culturais e crianças de outros grupos e zonas desfavorecidos ou marginalizados.

É o princípio de educação para todos, onde a escola regular deve recepcionar de forma indiscriminatória crianças e adolescentes. Desse modo, segundo o Ministério da Educação Secretaria de Educação Especial (2010), dos marcos político-legais da educação especial na perspectiva da educação inclusiva no Brasil, em 1999 houve outro Decreto de nํ.298, que regulamenta a Lei no 7.853/89 que menciona sobre a Política Nacional para a Integração da Pessoa Portadora de Deficiência que "define a educação especial como uma modalidade transversal a todos os níveis e modalidades de ensino, enfatizando a atuação complementar da educação especial ao ensino regular" (BRASIL, 2010, p.13).

\subsection{Século XXI}

Já no século XXI, mais especificamente em 15 de agosto de 2001, foi sancionada a resolução do Conselho Nacional de Educação (CNE) que estabelece as Diretrizes Nacionais para a Educação Especial na Educação Básica. A dimensão da implantação dessas Diretrizes é que, a partir de sua homologação, a Educação Especial começa a fazer parte do Sistema Geral de Educação, percorrendo todos os níveis e modalidades de ensino (CORRÊA, 2010). O direito do aluno com necessidades educativas especiais passa ser um direito constitucional.

Ainda, Corrêa (2010) evidência que a mudança expande o papel da Educação Especial e ressalta a inclusão de alunos especiais, expondo que se objetiva com esse documento elaborar meios e determinar aparatos legais para assegurar a inclusão de alunos com deficiência em toda a rede ensino básica. Para tal, os mecanismos de ensino e as escolas necessitam se regular em distintos aspectos, desde sua estrutura física até os currículos.

Para alunos com deficiência visual é significativo que seus docentes sejam capacitados e que a estes sejam certificados a adaptação dos meios de comunicação e dos materiais essenciais para seu aprendizado e desenvolvimento. A utilização desses recursos deve resultar na melhoria e na facilidade da aprendizagem dos alunos com deficiência visual, assim os motivando e estimulando seu interesse (SILVA; OLIVEIRA, 2012). 
Assim, Corrêa (2010) já mencionou que antes, na política de integração, era o aluno que devia se adaptar à escola, e agora com a homologação de diretrizes para a Educação Especial na Educação Básica, é o mecanismo de ensino que deve se regular e se estruturar para recepcionar os alunos com deficiência. Em 2008, nota-se uma redefinição no conceito de educação especial, conforme (BRASIL, 2008):

A educação especial é uma modalidade de ensino que perpassa todos os níveis, etapas e modalidades, realiza 0 atendimento educacional especializado, disponibiliza os recursos e serviços e orienta quanto a sua utilização no processo de ensino e aprendizagem nas turmas comuns do ensino regular.

Outra deliberação importante e homologada no ano de 2008 é o Decreto Presidencial $n^{\circ}$ 6.571, de 17 de setembro de 2008, conforme (BRASIL, 2008):

[...] trata do atendimento educacional especializado e tem a finalidade de ampliar a oferta do atendimento educacional especializado aos alunos com deficiência, transtornos globais do desenvolvimento e altas habilidades ou superdotação, matriculados na rede pública de ensino regular

O Atendimento Educacional Especializado - AEE pode ser definido como "conjunto de atividades, recursos de acessibilidade e pedagógicos organizados institucionalmente, prestado de forma complementar ou suplementar à formação dos alunos no ensino regular" (BRASIL, 2008). De acordo também com a Resolução CNE/CEB 4/2009 Art. 5o, estabeleceu como o AEE deve ser realizado, assim preferencialmente em uma sala especifica, com recursos multifuncionais da própria escola ou em outra localidade, desde que seja uma escola de ensino regular, em horário distinto da escolarização do aluno e não podendo ser substituído às classes comuns (BRASIL, 2009).

Desse modo, pode se suceder, também, em centro de Atendimento Educacional Especializado do sistema público ou de entidades comunitárias, confessionais ou filantrópicas (sem fins lucrativos), associadas com a Secretaria de Educação ou órgão análogo dos Estados, Distrito Federal ou dos Municípios (BRASIL, 2009). Assim, tendo como finalidade ampliar não somente 0 atendimento educacional, mas estabelecer parâmetros que ele possa ser ofertado com qualidade.

Em meio aos períodos de 2003 a 2010, muitas políticas relacionadas a educação especial receberam novas formas, que de acordo com Garcia e Michels, (2011, s.p.):

Ao longo do governo de Luís Inácio Lula da Silva (2003-2010), a Política Nacional de Educação Especial ganhou novos contornos mediante três programas de governo, dois voltados para a Educação Básica e um para a Educação Superior: 1) Programa de Implantação de Salas de Recursos Multifuncionais; 2) Programa Educação Inclusiva: direito a diversidade; 3) 
Programa Incluir. Tais programas contribuíram sobremaneira para a expansão dos fundamentos inclusivos na política de Educação Especial no Brasil na última década.

Atualmente, a educação inclusiva contempla a escola como um lugar para todos, no qual os discentes unificam seus conhecimentos e os constroem de acordo com suas capacidades. Assim, em escolas inclusivas não há conformidade com padrões que distinguem os alunos como especiais e normais, nesses ambientes todos se homogeneízam pelas suas diferenças.

\section{CONSIDERAÇÕES FINAIS}

A escola regular passou por significativas modificações ao longo dos anos, sendo estruturada por inúmeras diretrizes que possibilitaram a constituição de um ambiente integralizado. Para o aluno com deficiência visual novas abordagens e recursos de ensino-aprendizagem são utilizados para auxiliar no seu desenvolvimento educacional e social, assim o estimulando sempre no sentido de atingir seu potencial máximo.

Embora as propostas da educação inclusiva ainda não sejam praticadas em todas as escolas do país, muitas ações interessantes têm sido realizadas, o que sugere uma mudança nas ações e concepções de alguns educadores que cientes de seu papel social possibilitam que alunos com deficiência visual tenham acesso a escola e possam desenvolver todas as suas potencialidades. Que em um futuro breve, esta seja a regra praticada em todas as escolas e para todos os alunos.

\section{REFERÊNCIAS}

ARANHA, Maria Lúcia Arruda. História da Educação. São Paulo: Moderna, 1989.

ASSIS, Renata Machado de. A educação brasileira durante o período militar: a escolarização dos 7 aos 14 anos. In: _. Educação em Perspectiva, Viçosa, v. 3, n. 2, p. 320- 339, jul./dez. 2012.

BAPTISTA, Claudio Roberto et al. Colóquio: Política Nacional de Educação Especial na Perspectiva da Educação Inclusiva. Inclusão, Brasília, v. 18, n. 1, p. 18-32, jan./jun. 2008. 
BRASIL. Constituição (1988). Constituição da República Federal do Brasil. Brasília, DF: Senado Federal, 1988

BRASIL. Declaração de Salamanca e linha de ação sobre necessidades educativas especiais. Brasília: UNESCO, 1994.

BRASIL. Decreto n. 48.252, de 31 de mai. de 1960. Altera dispositivos do Decreto $\mathrm{n}^{\circ}$ 44.236, de 1 de agosto de 1958, Brasília, DF,1960.

BRASIL. Decreto no 1.044, de 21 de out. de 1969. Dispõe sobre tratamento excepcional para os alunos portadores das afecções que indica, Brasília, DF, 1969.

BRASIL. Decreto o 5.692, de 11 de ago. de 1971. Fixa Diretrizes e Bases para o ensino de $1^{\circ}$ e $2^{\circ}$ graus, e dá outras providências, Brasília, DF,1971.

BRASIL. Decreto o 6.571 , de 17 de set. de 2008. Dispõe sobre o atendimento educacional especializado, regulamenta o parágrafo único do art. 60 da Lei no 9.394, de 20 de dezembro de 1996, e acrescenta dispositivo ao Decreto no 6.253, de 13 de novembro de 2007, Brasília, DF, 2008.

BRASIL. Decreto no 63.258, de 19 de set. de 1968. Dispõe sobre o projeto especial prioritário do Programa Estratégico para o Desenvolvimento, denominado "Operação-Escola", Brasília, DF,1968.

BRASIL. Ministério da Educação. Secretaria de Educação Especial. Marcos político-legais da educação especial na perspectiva da educação inclusiva / Secretaria de Educação Especial. - Brasília: Secretaria de Educação Especial, 2010.

BRASIL. Resolução № 4, de 2 de out. de 2009. Institui Diretrizes Operacionais para o Atendimento Educacional Especializado na Educação Básica, modalidade Educação Especial, Brasilía, DF, 2009.

CORRÊA, Maria Angela Monteiro. Educação especial, v.1, - 5.a reimp. Rio de Janeiro: Fundação CECIERJ, 2010.

EFFTING, Juliana Hickmann. O serviço social nas instituições escolares: Um espaço em construção, 2008. Trabalho de conclusão de curso (bacharel em Serviço Social) - Centro de Ciências Sociais Aplicadas da Universidade Estadual do Oeste do Paraná. Paraná, p. 6-62.

FRANCO, João Roberto; DIAS, Tárcia Regina da Silveira. A educação de pessoas cegas no Brasil. Revista Avesso do Avesso, 2007; 5(5):74-82. 
FRANCO, João Roberto; DIAS, Tárcia Regina da Silveira. A pessoa cega no processo histórico: um breve percurso. Revista Benjamin Constant, Rio de Janeiro: DDI, n.30, p.1-9, abr./jul. 2005

GARCIA, R. M. C.; MICHELS, M. H. A política de educação especial no Brasil (1991) - (2011): uma análise da produção do GT15 - Educação Especial da ANPED. Revista Brasileira de Educação Especial, Marília, v. 17, p. 105-124, mai./ago. 2011. Edição especial.

INSTITUTO BENJAMIN CONSTANT. Uma História Centenária. Disponível em: http://www.ibc.gov.br/images/conteudo/revistas/benjamin_constant/1995/edicao-01setembro/Nossos_Meios_RBC_RevSet1995_Artigo1.doc. Acesso em: 16 de julho de 2018.

JANNUZZI, Gilberta. Algumas concepções de educação do deficiente. Revista Bras. Cienc. Esporte, Campinas, v. 25, n. 3, p. 9-25, maio 2004.

JÚNIOR, Edson Mendes; TOSTA, Estela Inês Leite. 50 anos de políticas de educação especial no Brasil: Movimentos, avanços e retrocessos. Seminário de pesquisa em educação da região Sul. 2012.

MASINI, Elcie F. Salzano. A educação do portador de deficiência visual - As perspectivas do vidente e do não vidente. Revista Em Aberto, Brasília, ano 13, n.60, p. 61-76,1993.

MAZZOTTA, Marcos José. Inclusão e integração ou chaves da vida humana. São Paulo: 2001. Disponível em: <www.educacaoonline.pro.br>. Acesso em: 16 de jun. 2018.

MELLO, Humberto de; MACHADO, Sídio. 1ํ seminário luso-brasileiro de educação inclusiva: o ensino e aprendizagem em discussão, ㄲo1, 2017, rio grande do sul. A formação histórica da educação para cegos no Brasil: uma análise contextualizada das leis do Império à República. Pontifícia Universidade Católica do Rio Grande do Sul, 26-40, 2017.

MENDES, Enicéia Gonçalves. A radicalização do debate sobre inclusão escolar no Brasil. Revista Brasileira de Educação, v. 11, n. 33, p. 387-405, 2006.

MENDES, Enicéia Gonçalves. Breve histórico da educação especial no Brasil. Revista Educación y Pedagogía, vol. 22, núm. 57, maio-agosto, 2010

SANTOS, Mônica Pereira dos. Perspectiva histórica do movimento integracionista na Europa. Revista Brasileira de Educação Especial, (3), p. 21-29. Piracicaba: UNIMEP, 1995. 
SASSAKI, ROMEU KAZUMI. Inclusão, o paradigma da década. Mensagem, Brasília, v.34, n.83, p.29, 1998.

SILVA, Natalí Sala da; OLIVEIRA, Thereza Cristina Bastos Costa de . Convivendo com a diferença: A inclusão escolar de alunos com deficiência visual. In: Seminário sobre Inclusão no Ensino Superior, 2012, Londrina. III SIES, 2012. 


\title{
A HISTÓRIA DA EDUCAÇÃO: A relevância da Educação Especial - APAEs na atual conjuntura Social
}

\author{
SILVA, Aline Lima da \\ Bacharel em Serviço Social - UNESP/Franca \\ CATANANTE, Flávia \\ Mestranda - Universidade Nacional da Rosária \\ REIS, Graziela Donizetti dos \\ Mestranda - UNESP/Franca
}

\section{INTRODUÇÃO}

\begin{abstract}
A historia não nos ensina nada, já que somos nos que, aprendendo com ela, ensinamos a nos mesmos. A historicidade, a historia, somos nos. Somos nos os professores e os discípulos nesta escola que e o nosso planeta (HELLER, 1982, p. 9)
\end{abstract}

Procuramos discutir e refletir sobre os avanços e desafios atuais da educação especial no Brasil seja no modelo escola de educação especial ou no modelo escola comum inclusiva. Iniciamos com a história da fundação da primeira Escola Especial na APAE, que durante muitos anos foi a única possibilidade de estudo oferecida ao aluno com deficiência, descrevemos como o processo de inclusão escolar tem sido construído, desconstruído e ressignificado frente às novas exigências sociais do mundo contemporâneo.

A pesquisa foi realizada através de um aprofundamento bibliográfico, com o objetivo de subsidiar 0 trabalho do pesquisador, atualizando seus conhecimentos na área em que já atua, apontando novos caminhos para reflexão e orientação de ações.

Buscamos na legislação brasileira, em documentos de apoio publicados por órgãos governamentais e da sociedade civil e em autores da área, os aspectos inclusivos do processo e que contribuem para a nossa reflexão com relação à situação atual, com discussões atualizadas da inclusão, extrapolando aspectos educacionais, invadindo aspectos sociais e contextos reais que demonstram todo o trabalho de conscientização que ainda está por ser feito.

\subsection{Breve trajetória da Política de Educação Especial no Brasil}

“Não há saber mais ou saber menos, há saberes diferentes.

Paulo Freire" 
A Educação Especial em seu processo histórico de efetivação perpassou por diversas transformações, indagações frente à inclusão das pessoas com deficiência, na denominada rede regular de ensino, o que nos estudos realizados para construção do presente artigo, verificamos que muito se avançou para que essas crianças, jovens e adultos, antes (in)visíveis na sociedade, tivessem seu direito garantido.

Para compreender essa trajetória de luta é imprescindível uma leitura da conjuntura social, política e econômica do Brasil, e como a educação especial no país se configurou. Segundo Mazzotta (2005, p.12), no Brasil definia-se a educação especial, sendo aquela que possibilitava assistência aos alunos com deficiência, e não tinha uma finalidade educativa, ou seja, o processo educativo era pautado, na visão de muitos, como inviável e até mesmo impossível. Tendo somente um atendimento clínico para esses educandas/os.

Sobre o prisma de Corrêa (2004, p.48),

A educação especial, após 1950, foi marcada por inúmeras estruturas administrativas. Se, em um primeiro momento, o serviço responsável pela Educação Especial era uma coordenação, logo a seguir passa a ser um centro e depois um departamento, até se tornar uma secretaria. Em cada mudança, há implicações funcionais, financeiras e de competências educacionais.

Contudo, observamos que é somente com a Constituição Federal de 1988 que a educação especial tem sua fundamentação, em seu Capítulo II a "competência comum da União, dos Estados, do Distrito Federal e dos Municípios: em cuidar da saúde e da assistência pública, da proteção e garantia dos direitos das pessoas com deficiência". Assim, também podemos verificar no Art. 205:

A educação, direito de todos e dever do Estado e da família, será promovida e incentivada com a colaboração da sociedade, visando ao pleno desenvolvimento da pessoa, seu preparo para o exercício da cidadania e sua qualificação para o trabalho. [...].

Art.208. O dever do Estado com a educação será efetivado mediante à garantia de: [...] III. atendimento educacional especializado aos portadores de deficiência ${ }^{1}$, preferencialmente na rede regular de ensino.

A promulgação da Constituição Federal foi um grande marco de mobilização social em prol de direitos, conquista esta, que contribuiu para fundamentações futuras de normativas que garantem os direitos das pessoas com deficiência.

Em 1994 a promulgação da Declaração de Salamanca vem reforçar e preconizar a metodologia de trabalho e o atendimento educacional

\footnotetext{
${ }^{1}$ É oportuno destacar que com a Lei Brasileira de Inclusão no 13.146 de 2015, o termo portador de deficiência deixou de ser usado, passando para o termo pessoa com deficiência, o que foi um grande avanço frente a nomenclatura.
} 
de forma gratuito as/os educandas/os com deficiência, de preferência na rede regular de ensino. Observamos que mesmo com as promulgações das legislações ainda não havia e há, na rede regular de ensino, um ensino que trabalhava de fato as potencialidades das/os educandas/os por meio do Currículo Funcional - leitura da realidade-, contudo, há um avanço quando nos reportamos às promulgações de legislações que enfatizam a inclusão educacional no país.

Assim, comungando com Paulo Freire (1981, p.18), "aos esfarrapados do mundo e aos que neles se descobrem e, assim, descobrindose, com eles sofre, mas, sobretudo, como eles lutam.", destarte, foram por meio de lutas para a visibilidade das pessoas com deficiência na sociedade que em 2001 foi aprovada as Diretrizes Nacionais da Educação Especial na Educação Básica, que enfatizava a formatação das escolas inclusivas na rede pública de ensino, sinalando ainda que a educação especial deveria acontecer nas escolas públicas como nas escolas privadas de ensino da rede regular.

Com a Lei de Diretrizes Básicas - LDB no 9.394 de 1996, a normativa vem estabelecer em seu Artigo 58 que a educação especial deverá ser oferecida, preferencialmente na rede regular de ensino, para educando com deficiência. Já em seu $\S 1^{\circ}$ a legislação enfatiza que "haverá, quando necessário, serviços de apoio especializado na escola regular, para atender às peculiaridades das/os educandas/os de educação especial".

Assim, antes havia a inexistência de normativas que ressaltavam de fato a importância do apoio do Sistema de Ensino para o processo educacional das crianças, jovens e adultos com deficiência. Entretanto, é válido destacar que este apoio e metodologia de ensino diferenciado havia nas instituições especializadas, a exemplo das APAEs.

Essa metodologia de trabalho, por meio da leitura de mundo2, observada no Artigo 59 da LDB que assegura o atendimento aos educandas/os com deficiência, através de "currículos, métodos, técnicas, recursos educativos e organização específica." Assim, este trabalho metodológico deve considerar a realidade de cada educanda/o, ter flexibilidade frente ao currículo geral, enfatizando ainda a especificidade de cada educanda/o.

Destarte, verificamos nos estudos de Paulo Freire (1981, p. 94) que "não basta saber ler mecanicamente que 'Eva viu a uva'. É imprescindível compreender qual a posição que Eva ocupa no contexto social, quem trabalha para produzir as uvas e quem lucra com esse trabalho". É esta leitura de mundo, de se reconhecer pertencente a uma determinada sociedade enquanto sujeito de direitos, que o trabalho desenvolvido por meio do Currículo Funcional

\footnotetext{
${ }^{2}$ Quando nós reportamos a leitura de mundo, fundamentamos em Paulo Freire em sua obra "Pedagogia do Oprimido", leitura esta, relevante para compreensão do ensino especial.
} 
é importante no desenvolvimento da autonomia e protagonismo desses educandas/os.

Desse modo, Mantoan ressalta que:

A inclusão é um conceito que emerge da complexidade, dado que a interação entre as diferenças humanas, 0 contato e 0 compartilhamento dessas singularidades compõem a sua idéia matriz. [...] (MANTOAN, 2002, p.86).

Assim, o trabalho metodológico diferenciado nas instituições deve possuir profissionais capacitados para auxiliar as/os educanda/os nesta leitura de mundo, independe de suas limitações, pois somente dessa maneira que realmente será possível concretizar de fato o processo de inclusão, não meramente uma inclusão educacional, mas uma inclusão social que efetivará com êxito o ensino e a aprendizagem.

\subsection{A Luta para Defesa e Garantia de Direitos das pessoas com deficiência no Estado de São Paulo: escolas das APAEs}

"A inclusão acontece quando... Se aprende com as diferenças e não com as igualdades - Paulo Freire"

A primeira Escola de Educação Especial do Brasil nasceu com a Associação de Pais e Amigos dos Excepcionais - APAEs, que iniciou seu atendimento para vinte (20) crianças, em duas classes de aula, permanecendo durante muitos anos como o único espaço para o desenvolvimento acadêmico da pessoa com deficiência. (APAE Brasil, 2019).

A Associação de Pais e Amigos dos Excepcionais - APAE, surgiu em onze de dezembro de mil novecentos e cinquenta e quatro (11/12/1954), fruto da motivação plantada pela Sra Beatrice Bemis a pais, professores, médicos e amigos de pessoas com deficiência, quando procurava uma escola para a sua filha diagnosticada com Síndrome de Down.

Segundo Oliveira (2017, p. 45):

A demanda das Escolas Especiais das APAEs cresceu e 0 movimento se especializou, atendendo hoje desde a Educação Infantil, a partir do nascimento, até à Educação Profissional e colocação no mercado de trabalho, sem limites de idade, perpassando pelo Ensino Fundamental Ciclo I, na modalidade regular e Educação de Jovens e Adultos - EJA, com uma metodologia diferenciada. Cada Escola que compõe a rede da APAE tem liberdade para definir, junto à comunidade na qual está inserida, o segmento etário e o nível de ensino a ser oferecido, de acordo com as peculiaridades locais.

O que não muda, são os princípios e valores compartilhados por toda a Rede Apaeana, baseados na Convenção dos Direitos das Pessoas com 
Deficiência (2009), que ressalta a "equidade e igualdade de direitos, respeito pela dignidade humana e direito à escolha, plena participação e inclusão social, respeito à diversidade humana, respeito pelas capacidades em desenvolvimento, expressos através da metodologia do Plano de Ensino Individualizado - PEl." (Pletsch e Glat, 2013, p. 60).

O PEI permite o desenvolvimento das capacidades da/o alun/o com respeito ao seu ritmo de aprendizagem. Utilizado como estratégia pedagógica diferenciada, o documento é elaborado a partir do estudo de caso realizado pela equipe multiprofissional, propondo um currículo único, individualizado, permitindo ao aluno percorrer um caminho subjetivo da própria aprendizagem, com a mediação da/o professor. (Pletsch e Glat, 2013, p. 98)

A Educação Especial passa a ser contemplada na Lei de Diretrizes e Bases da Educação somente em 1961, LDB n 4024/61, "a fim de integrá-los à comunidade" (Artigo 88) e já com o reconhecimento que o poder público, sozinho, não daria conta, regulamentando subvenções (Artigo 99).

Na LDB 5692/71, o termo "tratamento" é utilizado à educação da/o aluna/o com deficiência. Somente em 1973 o MEC cria o CENESP, Centro Nacional de Educação Especial, com normatizações para o atendimento dos alunos com deficiência, ainda sob um aspecto integracionista, assistencialista e isolado.

Desde o Decreto no 1216, de 27/04/1904, que isentava do processo de escolarização as pessoas com deficiência até a Lei Brasileira de Inclusão - LBI que defende a educação inclusiva e ao longo da vida, um caminho de grandes lutas foi e continua sendo traçado.

Segundo Sassaki (1997), o movimento de inclusão começou na metade dos anos 80 nos países mais desenvolvidos, na década de 90 em países em desenvolvimento e vai envolver todos os países nas primeiras décadas do século XXI, momento esse que estamos vivendo. Refletir sobre a forma como a educação inclusiva vem acontecendo é tarefa constante, com objetivo de aperfeiçoar os passos dados até então.

As opiniões se dividem entre os inclusivistas e inclusivistas radicais, segundo Mendes (2006, p. 45):

Os inclusivistas reconhecem os limites da escola quanto ao atendimento pleno ao aluno, em todas as suas necessidades de apoio, e os objetivos reduzidos de apenas transmitir conhecimentos e desenvolver habilidades para a vida. Os inclusivistas radicais sugerem a necessidade da reinvenção da escola, com a abertura de possibilidades de socialização, formação de amizades, interação social, oportunidade de mudanças nos pensamentos estereotipados e preconceituosos.

Matos e Mendes (2014, p.41) afirmam que "educar alunas/os com seus pares é importante para o seu desenvolvimento pleno, e não apenas para 
promover a socialização", além de ressaltar que para a educação inclusiva eficiente há necessidade de formação contínua de professores, convivência com a diversidade e relação família-escola.

O atendimento conjunto da/o educanda/o com a sua família é outro grande diferencial da Rede APAE. A escolarização da pessoa com deficiência é ampliada com o atendimento socioemocional da sua família por parte da equipe multidisciplinar. Acolher, orientar e acompanhar é tarefa de cada Unidade Apaeana, o que faz toda a diferença para o sucesso do processo de escolarização.

A Declaração de Salamanca (1994) abriu os olhos do mundo para aqueles que estavam escondidos e o número de alunos com deficiência no ensino comum vem crescendo e os esforços para acesso, permanência e ensino de qualidade para todos é percebidos nos documentos e publicados por todas as instâncias governamentais (Brasil, 2010). Na concepção de Salamanca, o conceito de escola inclusiva diz respeito ao desenvolvimento de uma pedagogia centrada na/o aluna/o, buscando meios de educar eficientemente a todos, independente das necessidades especiais de apoio que traz consigo, da qual todos as/os alunas/os matriculadas/os e frequentes possam se beneficiar.

Ao mesmo tempo em que a Declaração de Salamanca orienta para políticas públicas que oportunizam o acesso de todas as pessoas à educação, sugerindo ações que congreguem todas as esferas governamentais e a sociedade civil, oferece esclarecimentos para o processo que se estabeleceu e continua fluindo até os dias de hoje. Não basta instalar alterações arquitetônicas em prédios escolares, se a filosofia da escola não se atualizar. O processo de inclusão é muito maior do que transformações visíveis é transformação interna em cada cidadão, projetos políticos pedagógicos, filosofias institucionais. Incluir todas as pessoas no processo escolar significa lançar um olhar diferenciado e, sobre o currículo nacional, construir caminhos para o acesso ao conhecimento comum.

O próprio governo percebe as limitações da escola comum ao publicar, nas Diretrizes Nacionais para a Educação Especial na Educação Básica (Res. CBE/CNE nํ02/2001):

Art. 10. Os alunos que apresentem necessidades educacionais especiais e requeiram atenção individualizada nas atividades da vida autônoma e social, recursos, ajudas e apoios intensos e contínuos, bem como adaptações curriculares tão significativas que a escola comum não consiga prover, podem ser atendidos, em caráter extraordinário, em escolas especiais, públicas ou privadas, atendimento esse complementado, sempre que necessário e de maneira articulada, por serviços das áreas de Saúde, Trabalho e Assistência Social. 
Amparados por essa e outras publicações, o movimento apaeano se fortalece como defesa de direitos e atendimento escolar diferenciado oferecendo, além dos profissionais docentes, de apoio técnico e administrativo, suporte de profissionais da área médica e da assistência social. (Oliveira, 2017)

Há que se operar uma revisão do que tem sido feito na escola até agora, considerando os educandos como não estigmatizados, mas singularizados por sua história pessoal, materializando novos rumos para a educação geral.

Mesmo após a inclusão da Educação Especial como modalidade de ensino na Lei oㅜ 5692/71, as universidades não a incluíram em seus currículos de graduação, ocasionando em professores despreparados que sentem-se isolados quando deparam com conflitos em salas de educação inclusiva sem saber a quem recorrer, sem falar da carência ou despreparo do pessoal técnico, docente e administrativo da escola para acompanhar e apoiar o trabalho inclusivo, que nem sempre compreendem sua responsabilidade frente às atividades escolares.

Queiroz (2002, p. 76) verifica a desinformação, o desinteresse e o descompromisso da escola quanto à ação que se desenvolve na sala de aula inclusiva, como consequência atual deste processo.

A LDB no 9394/96 define a educação especial como modalidade de atendimento, orientando ações a serem implementadas para assegurar 0 processo inclusivo. O currículo adaptado, diferentes técnicas e métodos de ensino, o uso de tecnologias assistivas e formação docente adequada são requisitos mínimos a serem implementados.

O fato é que ainda hoje a formação universitária, de todas as áreas, ainda não incluiu de forma efetiva, estudos relacionados às necessidades especiais de alunas/os, deixando uma lacuna que por vezes a formação continuada não consegue suprir.

Diante do exposto, a escola especial da rede apaeana continua avançando em superação, capacitando não somente os seus colaboradores, mas todos os profissionais interessados em incluir e garantir os direitos das pessoas com deficiência e sua família.

Assim, o trabalho multidisciplinar desenvolvido pelas/os profissionais das APAEs do Estado de São Paulo, visa um olhar para além do imposto na atual Política Educacional, haja vista que ao considerar as peculiaridades e história de vida de cada um, através de um processo educacional vem impactando diretamente na vida desses usuários e de suas famílias. 


\section{CONSIDERAÇÕES FINAIS}

Uma educação de qualidade para todos é o grande objetivo da Educação na perspectiva inclusiva que defende a heterogeneidade como um aspecto positivo para o crescimento intelectual, social e cultural de todos os indivíduos.

O que se observa de avanços na educação em geral é a acessibilidade do portador de deficiências tanto na rede pública como privada, pela compreensão das famílias e dos educadores que a escola não se constitui apenas um espaço terapêutico, mas também um ambiente para interação e de aprendizagem.

Numa sociedade onde se privilegia a cultura do belo, do rico, do talentoso, do bem-sucedido, a entrada da pessoa portadora de deficiência ou de necessidades especiais representa o início de uma quebra de paradigmas ortodoxos, para dar lugar ao reconhecimento dos direitos para que todos os indivíduos possam ser aceitos e seus direitos praticados, principalmente a educação de qualidade para todos. A educação inclusiva é um avanço irreversível, segundo Queiróz (2002) e se completará quando a escola alcançar a plenitude da sua missão: um espaço aberto para todos os indivíduos, com um atendimento que promova a aprendizagem respeitando as características de cada pessoa, o ritmo e a forma de aprender, oportunizando crescimento interno rumo à verdadeira cidadania com habilidades para refletir sobre seu cotidiano, desenvolver atitudes e habilidades básicas, de gestão e específicas, que contribuam para a tomada de decisões que definam os rumos da sua vida. Ao educador cabe buscar os recursos e as novas teorias na prática do dia-a-dia, à sociedade conhecer os direitos, as causas e respeitar a pessoa portadora de deficiência, quebrando barreiras culturais e arquitetônicas.

\section{REFERÊNCIAS}

BRASIL. Decreto n.1.216, de 27 de abril de 1904. Approva e manda observar o Regimento Interno dos Grupos Escholares e das Escholas Modelo.

.Constituição Federal, 1988. Disponível

em:<http://www.planalto.gov.br/ccivil 03/constituicao/constituicao.htm CF 88>. Acesso em: 03/04/2019. 
Decreto 6949/2009.Promulga a Convenção Internacional sobre os Direitos das Pessoas com Deficiência e seu Protocolo Facultativo, assinados em Nova York, em 30 de março de 2007.

- Instituto Nacional de Estudos e Pesquisas educacionaisAnísio Teixeira (INEP). Censo Escolar 2010. Resumo Técnico.Disponível em: $<$ http://portal.mec.gov.br/index.php?option=com_content\&view=article\&id=1617 9>.

. Lei 9394/96. Estabelece as diretrizes e bases da educação nacional.

. Lei 13146/2015. Institui a Lei Brasileira de Inclusão da Pessoa com Deficiência (Estatuto da Pessoa com Deficiência).

- Ministério da Educação. Ministério da Educação. Secretaria de Educação Especial. Marcos Político-Legais da Educação Especial na Perspectiva da Educação Inclusiva. Brasília, SEE, 2010.

.RESOLUÇÃO CNE/CEB № 2, DE 11 DE SETEMBRO DE 2001.(*) Institui Diretrizes Nacionais para a Educação Especial na Educação Básica.

CONFERÊNCIA MUNDIAL SOBRE NECESSIDADES EDUCATIVAS ESPECIAIS: ACESSO E QUALIDADE Salamanca, Espanha, 7-10 de Junho de 1994.

CORRÊA, Maria Ângela Monteiro. Educação Especial. Rio de Janeiro: Fundação CECIERJ,2004.

FREIRE, Paulo. Pedagogia do Oprimido. $9^{a}$ ed. Rio de Janeiro, Paz e Terra, 1981.

GLAT, R.; Pletsch, M. D. Estratégias educacionais diferenciadas para alunos com necessidades especiais. Rio de Janeiro, EdUERJ, 2013.

HELLER, A. Teoría de la historia. Barcelona: Fontamara. 1982.

MANTOAN, Maria Teresa Eglér. Inclusão escolar: O que é? Por quê? Como fazer? São Paulo:Moderna, 2003.

MATOS, S.N.; MENDES, E.G.A proposta de inclusão escolar no contexto nacional de implementação das políticas educacionais.Práxis Educacional, Vol. 10, No $16,2014$.

MAZZOTTA, M. J. S. Educação Especial no Brasil: histórias e políticas. São Paulo:Cortez, 2005. 
OLIVEIRA, F. M. das G. S. (Orgs.) Documento norteador: educação e ação pedagógica Brasília, 2017.

QUEIROZ, P. Educação Inclusiva e Gestão Escolar. Gestão em rede, p. 1620, out/2002.

SASSAKI, R K. Inclusão - Construindo uma sociedade para todos. Rio de Janeiro: WVA, 1997. 


\title{
AS DIFICULDADES DE INSERÇÃO DO ADOLESCENTE AUTOR DE ATO INFRACIONAL NA POLÍTICA DA EDUCAÇÃO: Obstáculos cotidianos
}

\author{
GOMES, Eddara Santos \\ Graduanda em Serviço Social - UNESP Franca \\ gomesdara251@gmail.com \\ PIANA, Maria Cristina \\ Professora do Curso de Serviço Social- UNESP Franca \\ crispiana@uol.com.br
}

\section{INTRODUÇÃO}

O presente artigo busca compreender as dificuldades de inserção e permanência dos adolescentes autores de ato infracional na política de educação, dando ênfase nos obstáculos a serem enfrentados cotidianamente. Para tanto, é imprescindível construir uma breve contextualização da história da educação de crianças e adolescente, visto que o direito à educação só foi instaurado de fato, a partir da Constituição Federal de 1988.

Um dos primeiros contatos que as crianças nativas tiveram com a educação, foi a partir do método dos jesuítas que implementaram ensinamentos, com o intuito que, posteriormente, repassassem para os mais velhos. Estes ensinamentos eram pautados em uma forte disciplina, com o intuito de adotar "bons costumes", assim, a educação das crianças "era um dos instrumentos de civilização influenciando nas organizações comunitárias, nas relações de poder entre adultos e crianças, e no processo de construção das infâncias brasileiras" (AZEVEDO; SARAT, 2019, p.22)

Além desta forma de educação, a imagem constituída da criança brasileira pela Companhia de Jesus no Brasil, era de uma criança santa, inocente, bondosa, imitando e seguindo os passos de Jesus. A primeira escola no Brasil foi criada pelos jesuítas, na qual:

Tais escolas estavam voltadas para atividades como leitura, escrita, matemática e ainda aprendizagem de canto e música utilizada para facilitar a catequização. A escola tornouse, para os jesuítas, um mecanismo de atração às crianças: utilizavam métodos pedagógicos centrados na disciplinalização do corpo e da alma, no intuito de fazêlos se desprender dos velhos costumes considerados bárbaros, rudes e selvagens, e adquirir a "civilização dos modos. (AZEVEDO; SARAT, 2019, p.23) 
Contudo, a implantação desta forma de educação, resultou diversos conflitos e resistências. Já nesta época, o acesso à educação era fragmentado por classes sociais e principalmente, pela questão étnico-racial, dado ao fato que havia uma diversidade de grupos, desde crianças nativas, escravas, até filhas de senhores de engenho. Quanto ao acesso ao conhecimento, "as educação da criança escrava era inexistente" (FARIAS, 2005), enquanto que, as crianças brancas, eram educadas dentro da casagrande ou nas escolas jesuítas, através de pessoas contratadas pela família, denominadas de "preceptores".

Contudo, apesar da forte entrada da educação pelos jesuítas, outras formas de ensino foram realizadas no Brasil. A Santa Casa de Misericórdia, por exemplo, era destinada a acolher órfãos, pobres e expostos era atribuída a responsabilidade da educação daqueles que, de acordo com a legislação vigente eram "encontrados em estado de abandono, onde quer que seja.” (BRASIL, 1927).

No século $\mathrm{XV}$, as crianças eram tratadas como "adulto em miniatura" desconsiderando totalmente suas particularidades e seu desenvolvimento. Assim, quando apresentassem condições físicas, eram inseridas para trabalhar conjuntamente com suas famílias, auxiliando nas plantações, na produção de alimentos, na pesca, na caça, entre outras tarefas. A educação também era voltada para práticas no campo, e transferidas pelas próprias famílias, a partir de suas experiências cotidianas. Segundo, Del Priore (2013, p.10) "o ensino público só foi instalado, e mesmo assim de forma precária, durante o governo do marquês de Pombal, na segunda metade do século XVIII" dispondo mais uma vez, de uma grande fragmentação do acesso ao ensino.

Para assegurar o direito à educação formal, pública e universal, foi preciso quase um século com reivindicações e lutas por diferentes áreas da sociedade, unindo seus esforços para que o direito seja assegurado.

[...) no Brasil, a educação será pensada, no início do século XIX, como fator civilizador capaz de garantir, mediante extensão da educação moral e instrução elementar à população livre, condições de governabilidade. [...] O debate em torno da educação no Brasil e sua importância deu-se no diálogo com o contexto europeu, no qual Estados-nação investiam na educação como fator promotor da coesão nacional (GOUVÊA, 2008, p. 202)

Foi somente a partir da década de XX, mais especificamente com a Carta Constitucional de 1988, que o ensino passa a ser "direito de todos e dever do Estado e da família" (BRASIL, 1988). Dois anos após a aprovação da Constituição Federal de 1988, foi implantado o Estatuto da Criança e do Adolescente que também dispunha em seu artigo 53 do direito à educação, 
como responsabilidade do Estado, dos pais e da sociedade civil, gozando de todos os direitos fundamentais inerentes a pessoa humana em pleno desenvolvimento, assegurado de proteção integral. É importante ressaltar também que, no dia 20 de Dezembro de 1996, foi promulgada a primeira Lei de Diretrizes de Bases da Educação Nacional-FHC, pelo ex-presidente Henrique Fernando Cardoso, que regulamenta o sistema de ensino público, gratuito e obrigatório a partir dos quatro anos de idade.

[...] A responsabilidade de organização da educação é compartilhada pelos governos Federal, Estadual e Municipal: o primeiro é responsável, primordialmente, pelas instituições de ensino superior, o segundo, pelas instituições de ensino fundamental e médio, e o terceiro, pelos estabelecimentos de educação infantil e fundamental. (FINETTE, GOMES; 2018, p.1)

Apesar da responsabilização dos governos, o Brasil ainda enfrenta grandes dificuldades na implementação dos direitos sociais. Embora tenha avançado nos direitos constitucionais, ainda há uma grande falha na plena efetivação dos mesmos. O Estado, muitas vezes, transfere sua obrigação para a família ou para instituições filantrópicas, reforçando o caráter caritativo e moralizador existente nas décadas passadas. Oferta serviços fragmentados que deixam as classes subalternas descobertas de seus direitos essenciais, rompendo com a lógica de proteção social e reforçando a punição. Muito mais que assegurar o direito em lei, é preciso que o Estado oferte condições objetivas para sua efetivação.

Dados de um estudo realizado pela UNICEF no ano de 2015 mostram que:

No Brasil, 2,8 milhões de meninas e meninos de 4 a 17 anos estavam fora da escola em 2015. Desse total, quase 1,6 milhão tinham entre 15 e 17 anos, haviam passado pela escola, mas evadiram, e outros 820 mil estavam fora da educação infantil, podendo ter esse direito perdido para sempre. (...)

Por vez, os adolescentes autores de ato infracional aqui estudados, são um dos que mais sofrem com a fragmentação dos direitos assegurados em lei, ao fato que, ao cometerem ato infracional - e entende este como resultante do processo de acumulação capitalista-, já estão descobertos da proteção social. Outro estudo realizado pela UNICEF no ano de 2018 afirma:

[...] a exclusão escolar afeta principalmente meninos e meninas das camadas mais vulneráveis da população, já sem outros direitos constitucionais. Do total fora da escola, $53 \%$ vivem em domicílios com renda per capita de até $1 \frac{1}{2}$ salario mínimo. 
É por esse e tantos outros motivos que serão apresentados neste artigo, que os adolescentes encontram dificuldades de permanecerem no ambiente escolar.

\section{O ESTATUTO DA CRIANÇA E DO ADOLESCENTE E A ESCOLA.}

De acordo com o art. 103 do Estatuto da Criança e do Adolescente "considera-se ato infracional a conduta descrita como crime ou contravenção penal", (BRASIL, 1990) assim comprovada a prática do ato infracional poderão ser aplicadas as medidas socioeducativas previstas no art 112: "I- advertência; II-obrigação de reparar o dano; III-prestação de serviços à comunidade; IV- liberdade assistida; V-inserção em regime de semiliberdade; VI-internação em estabelecimento educacional; VII-qualquer uma das previstas do art. 101, I a VI." (BRASIL, 1990)

Com exceção das medidas I e II, todas as outras são acompanhadas de instruções que incluem a inserção em estabelecimentos educacionais. A Liberdade Assistida é exercida em caráter aberto, na qual, o adolescente é acompanhado por um orientador social contratado, de acordo com a Lei 12.594/2012 que dispõe do Sistema Nacional de Atendimento Socioeducativo. De acordo com o art 119 ao orientador, é atribuído a responsabilidade de "supervisionar a frequência e o aproveitamento escolar do adolescente, promovendo, inclusive, sua matrícula." (BRASIL 1990). Já na Semiliberdade que consiste em uma medida que "implica restrição de liberdade" durante a semana e aos finais de semana, retornam para suas casas, no período em que estão cumprindo a medida, o "adolescente deverá participar de atividades externas, com a obrigação de inserir-se na escola". Por fim, no regime de internação, por mais que seja uma medida restritiva de liberdade, o ensino dentro do Centro de Atendimento Socioeducativo ao Adolescente (Fundação Casa) é responsabilidade da União, dos Estados e dos Munícipios, pautados à Secretaria Estadual da Educação por meio da SEE n'109 de 13 de Dezembro de 2003 e no Estatuto da Criança e do Adolescente:

Art. 124. São direitos do adolescente privado de liberdade, entre outros, os seguintes:

(...)

$\mathrm{XI}$ - receber escolarização e profissionalização;

(BRASIL. 1990)

Por fim, embora todas as legislações caminhem para a inserção do adolescente autor de ato infracional na política de educação, sabe-se que "a relação entre os adolescentes em conflito com a lei e a escola nem sempre é tão harmônica como prescrita pelos documentos que regem sua inserção no sistema educacional formal (ARROYO, 2007; DIAS; 2011; FERREIRA, 2011)". Há grandes dificuldades de inserção e permanência nesses ambientes e são 
diversos os fatores que contribuem para que o processo de ensino seja mais laborioso e desafiador.

\subsection{Fatores econômicos significativos}

É de extrema importância situarmos o contexto econômico dos adolescentes autores de ato infracional na escolarização Ao fato que, a prática do ato infracional hoje, está relacionada à ausência de políticas públicas na sociedade contemporânea. Por sua vez, ao se depararem privados de direitos essenciais, encontram grandes obstáculos para encontrar sentido na escolarização. Uma vez que, das poucas alternativas que the são ofertados, disputar espaço com o tráfico de drogas é uma tarefa extremamente difícil, pois além deste ofertar um retorno econômico instantâneo, também ganham um "status" dentro das suas relações sociais. Segundo dados: "em 2002, um total de $51 \%$ dos adolescentes com medida de internação estavam fora da escola no momento da apreensão e $6 \%$ não eram alfabetizados (ASSIS; CONSTANTINO, 2005)".

Além da ressignificação da escolarização, outro fator de extrema importância e que muitas vezes, contribui para a evasão escolar, é o fato dos pais/responsáveis não darem suporte aos estudos. Este fato está muito relacionado com a realidade dos adolescentes, ao fato que os pais/responsáveis são parte da classe trabalhadora que estão entrelaçados nesse sistema que utiliza da máxima força de trabalho do sujeito, devolvendo o mísero para sua sobrevivência. Muitos não obtiveram oportunidade de estudos ou nunca nem sequer chegaram a frequentar uma escola, pois começaram a trabalhar desde muito cedo.

[...] dados constam que $33,3 \%$ dos pais dos adolescente são autônomos e não têm uma profissão nem uma renda fixa durante 0 mês, vivendo de pequenos bicos (...). Dessas famílias $61 \%$ são beneficiarias do programa Bolsa Família, auxilio que se torna um complemento na renda familiar. Ainda conforme levantamento de dados o grau de escolaridade dos pais desses adolescentes, $5,8 \%$ estão cursando ou têm curso superior, $9,80 \%$ concluíram o ensino médio, 9,80\% apresentam ensino fundamental incompleto, o que também dificulta a esses chefes de família conseguirem se inserir em ocupações com salários mais elevados, que proporcionem melhores condições de vida a seus membros (SALES, FIGUEIREDO; 2016).

Assim, grande parte dos adolescentes ao se depararem sob estas condições econômicas sente-se responsáveis pela manutenção da casa, optando por atividades licitas ou ilícitas que deem retorno econômico, de forma a ajudar na manutenção da sua subsistência. Segundo Martins et at (2005), a população que vive com baixa renda e enfrenta grandes dificuldades financeiras, em vulnerabilidade social, acaba estando mais sujeita a desistir da 
escola, reproduzindo a escolaridade apresentada pela família, e também a pobreza, em situações que o expõem a marginalização.

\subsection{Outros fatores a serem considerados}

Conjuntamente com esses fatores econômico, uma questão de extrema importância é a questão do pertencimento no ambiente escolar. Os motivos apontados pelos adolescentes autores de ato infracional, em pesquisas realizadas, acerca das causas da evasão escolar, resultam em: desinteresse, envolvimento com entorpecentes, conflito com docentes e alunos, reprovação, dificuldade em conciliar trabalho e escola, entre outros. Percebe-se que, uma causa está totalmente ligada às outras. Quando um adolescente não se identifica com o ambiente escolar, a probabilidade dele não ter um rendimento satisfatório aumenta muito. Segundo Patterson, DeBaryshe e Ramsey (1989) (...) sentindo o fracasso, tanto acadêmico como relacional, o adolescente abandona a escola em busca de grupos com história similares.

Os adolescentes por sua vez, enfrentam uma série de fatores no ambiente externo e ainda, o ambiente escolar não oferece possibilidade de inclusão. A escola por vez, não está preparada para receber o aluno que cometeu ato infracional, por mais que identificam a necessidade da (re)inserção da escolarização, enfrentam a pressão dos pais e dos alunos. Como resposta à essas pressões, rejeitam a matrícula do aluno, verbalizando não haver vagas ou não possuírem capacitação pedagógica para acolhê-lo.

[...] geralmente no contato com as escolas é apontado a falta de vagas nas escolas (...) as hipóteses levantadas são que, ou de fato as escolas não possuem essas vagas (...) ou ainda ser fruto de preconceito sobre 0 adolescente ser egresso da medida socioeducativa.

(LUCIANO, 2015)

Apontam também, a exclusão do adolescente por não se encaixar nos padrões impostos pela sociedade, identificando-os como um perigo para os demais alunos.

[...] esse aluno [LA] é um perigo. Eu o visualizo como a fruta podre dentro de um cesto de frutas saudáveis. Porque se ele é um bandido e está sendo inserido dentro da escola, é o lobo que vai pegar suas ovelhas, certo? Ele é inserido na comunidade escolar, onde existem seres humanos em formação.

(ABRAMOVAYM 2009, p.183)

Os profissionais entendem a importância do adolescente se inserir no ambiente escolar, pois é requisito para sua formação, o estudo tanto do Estatuto da Criança e do Adolescent como da Lei de Diretrizes e Bases da Educação, mas ainda sentem muita dificuldade no acompanhamento desses 
alunos. Por sua vez, essa dificuldade está relacionada ao modelo de instituição escolar existente.

O que vemos hoje são salas lotadas e professores cada vez mais sobrecarregados no processo de ensino, o que contribui para que o processo educativo seja feito nos moldes, segundo Paulo Freire, de uma "educação bancária", que consiste no depósito de conteúdos nos alunos, sem que eles tenham a oportunidade de questionar sobre aquilo que está aprendendo ou da relevância daquilo para suas vidas.

Este processo contribui para o desinteresse dos adolescentes, enxergando a escola como algo "chato" e sem relevância. Por mais que entendem a necessidade dos estudos e isto por sua vez, "diminui as chances de se conseguir empregos mais bem remunerados e aumenta a de viver na pobreza e depender economicamente de benefícios sociais (ZHANG et al, 2010)" acabam optando por abandonarem os estudos, até completarem idade para se matricularem no EJA (Educação de Jovens e Adultos), CEEJA (Centro Estadual de Educação de Jovens e Adultos) ou outros programas que ofertam oportunidades de concluírem o ensino médio de forma que, não tenha que passar por toda humilhação, segregação que o ambiente escolar proporciona e que seja um processo rápido e sem burocracias.

Tamo vendo um colégio aí lá na Messejana, o CIES, que a pessoa vai lá só pegar as provas. Estuda é em casa. Aí eu vou fazer esse mermo. A gente quer estudar e neguinho já recebe com sete pedra na mão.

(CRUZ, 2010, p.236)

Fazendo um paralelo com o livro do pedagogo Dermeval Saviani em seu livro "Escola e Democracia", este analisa como a escola pode ser tanto um fator de emancipação, quanto de marginalização. A emancipação por sua vez, busca a integração entre todos os membros de forma a superar as fragmentações e buscar uma sociedade igualitária. Já na marginalização, uma vez que é "entendida como um fenômeno inerente à própria estrutura da sociedade" esta ao dividir a sociedade em classes acaba "cumprindo aí a função de reforçar a dominação e legitimar a marginalização". Neste contexto, a escola para os adolescentes autores de ato infracional, pode ser um ambiente de marginalização, uma vez que não cumpre com a função de aproximar os seus membros, mas de segregar aquilo que é posto como "diferente". O adolescente quando não se apropriam dos meios materiais, são envoltos por uma força discriminatória e segregadora:

[...] marginalizados são os grupos ou classes dominados. Marginalizados socialmente porque não possuem força material (capital econômico) e marginalizados culturalmente, porque não possuem força simbólica (capital cultural). E a educação, longe de ser um fator de superação da marginalidade, constitui um elemento reforçador da mesma (SAVIANI, 1999). 
É importante compreender que esse sistema é fruto da sociedade capitalista contemporânea que se apropria dos meios de produção e tem uma forte acumulação do capital. Esta, por sua vez, segrega as suas classes, deixando que os jovens não consigam potencializar seus sonhos e seus desejos, pois enxergam o seu fracasso, como algo natural, pois onde seria 0 ambiente que possibilitaria emancipação, acaba tornando-se um ambiente de marginalização. Ainda segundo Saviani (1999):

A escola é determinada socialmente; a sociedade em que vivemos, fundada no modo de produção capitalista, é dividida em classes com interesses opostos; portanto, a escola sofre a determinação do conflito de interesses que caracteriza a sociedade (SAVIANI, 1999).

Quando os adolescentes retornam para a instituição escolar do bairro de origem, faz com que alguns alunos que já conhecem e sabem da trajetória do adolescente, o estigmatizam como algo "ruim", "perigoso", "bandido", etc. Por vez, a escola não sabendo lidar com o adolescente egresso do sistema socioeducativo, acaba reforçando esta segregação, que resultará em uma evasão escolar. Fala-se tanto em inclusão na escola, mas esquecem que não é somente a inclusão mas também a permanência do adolescente que é de extrema importância, pois esta se mostra muito mais desafiadora do que a própria (re)inserção.

[...] os adolescentes infratores não são bem vistos pelos demais colegas e até mesmo pelos professores, à medida que fugiram do que é considerado normal frente às regras sociais, dificultando ainda mais sua reinserção no meio social e escolar.

(MARTINS et al, 2005)

É preciso que a escola ofereça capacitação para toda a equipe escolar, de modo a compreender a (re)inserção do adolescente autor de ato infracional como um direito e que este, não deve ser violado. Ao fato que, a escolarização é parte fundamental da vida de um individuo, possibilitando desenvolver capacidades críticas, desenvolvimento psicossocial, além de oferecer uma emancipação social, econômica e intelectual.

\section{CONSIDERAÇÕES FINAIS}

O desenvolvimento deste presente estudo, possibilitou compreender como a (re)inserção do adolescente autor de ato infracional na política de educação ainda é um trabalho muito árduo. Ao analisarmos as elevadas taxas de evasão escolar, podemos compreender o quanto o ambiente 
escolar precisa ser trabalhado na perspectiva de assegurar a permanência do aluno na escola.

A falta de políticas públicas voltadas para a educação, é um fator de extrema relevância para contribuir que o ambiente escolar seja cada vez mais desafiador. A busca de estratégias inclui uma boa capacitação para todos os docentes, um ambiente aconchegante, uma boa infraestrutura, locais que os adolescentes consigam estudar mas também consigam ter um momento de recreação. É difícil dizer um modelo ideal de escola hoje, mas a ausência de atividades laborais e pedagógicas acaba tornando o ambiente muito mais difícil de garantir a continuidade dos estudos.

Por fim, é preciso que entenda as condições sociais, culturais e econômicas que levam o adolescente a entrar na criminalidade. E a escola, precisa ser um ambiente que busca a emancipação destes jovens:

[...] a educação será um instrumento de correção da marginalidade na medida em que contribuir para a constituição de uma sociedade cujos membros, não importam as diferenças de quaisquer tipos, se aceitem mutuamente e se respeitem na sua individualidade específica (SAVIANNI, 1999).

Deste modo, é preciso romper com toda segregação, marginalização e exclusão, pois a escola pode ser um forte potencializador das capacidades destes jovens, rompendo com todo contexto que contribui para o seu envolvimento com o ato infracional e com práticas violentas.

\section{REFERÊNCIAS}

ASSIS, S. G.; CONSTANTINO, P. Perspectivas de prevenção da infração juvenil masculina. Ciência e Saúde Coletiva, Rio de Janeiro, v. 10, n. 1, p. 8190, 2005. http://dx.doi.org/10.1590/ S1413-81232005000100014

AZEVEDO, Gislaine; SARAT, Magda. HISTÓRIA DA INFÂNCIA NO BRASIL: CONTRIBUIÇÕES DO PROCESSO CIVILIZADOR.Educação e Fronteiras On-line, Dourados/ms, v. 5, n. 13, p.19-33, jan./abr. 2015.

BRASIL. Código de Menores. Decreto n 17.943 A, de 12 de outubro de 1927.

Lei 9.394: Lei de Diretrizes e Bases da Educação Nacional. DF, Brasília: MEC, 1994.

Estatuto da Criança e do Adolescente. Lei 8.069/90. São Paulo: Ministério da Justiça, 1990. 
Nacional,1988.

Constituição da República Federativa Brasil. DF, Brasília: Congresso . Lei $n^{\circ}$ 6.697/79. Estabelece o Código de Menores. Brasília: Senado, 1979.

CRUZ, Ana V. H. O adolescente em conflito com a lei e a escola: criminalização e inclusão perversa. Universidade Federal do Rio Grande do Norte. Natal, 2010.

FARIAS, Mabel. Infância e educação no Brasil nascente. In: VASCONCELLOS, Vera Maria Ramos de. Educação da infância: história e política. Rio de Janeiro: Editora DPA, 2005

FINETTE, Carolina Rodrigues; GOMES, Eddara Santos. O papel da gestão escolar na reinserção educacional do adolescente autor de ato infracional. Franca, 2019

GOUVÊA, Maria Cristina Soares. A escolarização da "meninice" nas Minas oitocentistas: a individualização do aluno. In: VEIGA, Cynthia Greive; FONSECA, Thais Nivia de Lima e. História e historiografia da educação no Brasil. Belo Horizonte: Autêntica, 2008.

LUCIANO, Isabel Cristina Santos Martins A INCLUSÃO ESCOLAR DE ADOLESCENTES EGRESSOS DA MEDIDA SOCIOEDUCATIVA DE INTERNAÇÃO. 2015. 41 f. Monografia (Especialização) - Curso de Psicologia Escolar e do Desenvolvimento Humano, Universidade de Brasília, Brasília, 2015.

ORTEGAL, Leonardo Rodrigues de Oliveira. A medida socioeducativa de liberdade assistida: fundamentos e contexto atual. 2011. 145 f. Dissertação (Mestrado) - Curso de Serviço Social, Universidade de Brasília, Brasília, 2011.17, jan. 2016.

PATTERSON, G. R.; DEBARYSHE, B. D.; RAMSEY, E. A developmental perspective on antisocial behaviour. American Psychologist, Washington, v. 44, p. 329-335, 1989. http:// dx.doi.org/10.1037/0003-066X.44.2.329

PRIORE, Mary Del (Org.). História das crianças no Brasil. 7. ed., $1^{a}$ reimpressão. São Paulo: Contexto, 2013.

Mary Del (Org.). O papel branco, a infância e os jesuítas na colônia. In: PRIORE, Mary Del (Org.). História da criança no Brasil. 4. ed. São Paulo: Contexto, 1996.

SALES, Marialva dos Santos; FIGUEIREDO, Vanessa Catherina Neumann. A (RE) INSERÇÃO DO ADOLESCENTE EM CONFLITO COM A LEI NA ESCOLA REGULAR. Curso de EspecializaÇÃo EducaÇÃo, Pobreza e Desigualdade Social, Mato Grosso do Sul, v. -, n. -, p.1- 
SAVIANI, Demerval. Escola e Democracia. Edição Comemorativa. Campinas: Autores Associados, 2008. 112p. UNICEF. Cenário da exclusão escolar no Brasil. Brasil: UNICEF, 2018. 16p. Disponível em: http://www.crianca.mppr.mp.br/arquivos/File/publi/unicef/cenario_exclusao_esc olar_brasil.pdf Acesso em: 4 jun. 2019. 


\title{
DIVERSIDADE, DEFICIÊNCIA E ESCOLA: A educação inclusiva como questão de direitos humanos e cidadania
}

\author{
SPINIELI, André Luiz Pereira \\ Mestrando em Direito - UNESP \\ spinieliandre@gmail.com
}

\section{INTRODUÇÃO}

Os direitos humanos são fontes de significativas lutas sociais travadas ao longo da história ocidental da humanidade, aparecendo como parte substancial da natureza humana, vez que hoje já não mais são produtos que dependem completamente do reconhecimento jurídico formal ou mesmo de qualquer consciência social que tenha por finalidade aceitá-los, porquanto suas existências se encontram baseadas em uma perspectiva que foge às balizas puramente jurídicas, atingindo um plano verdadeiramente metajurídico.

No contexto de reconhecimento dos direitos considerados tipicamente fundamentais à vida humana, as declarações internacionais despontam como as principais referências jurídicas e sociais para a enunciação dos direitos humanos, dentre as quais, diante do objeto de estudo deste escrito, se destaca a Convenção Internacional sobre os Direitos das Pessoas com Deficiência, promulgada no ano de 2008, responsável por inaugurar outra perspectiva de enfrentamento à efetivação dos direitos fundamentais desse grupo, rotulado internacionalmente pelos aspectos de patente vulnerabilidade social, com maior autonomia e independência.

Não obstante a existência de outros direitos positivados no documento, a educação para pessoas com deficiência em geral ainda é reputada como um dos principais objetos de discussão no âmbito jurídico doméstico e internacional, sobretudo no que tange à implementação de uma educação propriamente inclusiva e capaz de transmitir os direitos de cidadania e de ensinar na cidadania. Certo é que a importância dos direitos educacionais para pessoas com deficiência não se esgota na mera realização do processo de promoção da diversidade social, com a participação de pessoas que possuem histórico de exclusão no campo dos projetos coletivos, mas também atingem esses indivíduos, na condição de atores do próprio movimento de inclusão social, em relação ao protagonismo de lutas que visam ao reconhecimento de uma situação de sujeito de direitos.

O reconhecimento aludido pode ser simplificado a partir da seguinte equação: sendo as pessoas com deficiência pessoas humanas, certamente gozam dos mesmos direitos que as pessoas que não possuem 
quaisquer deficiências, ainda mais no campo educacional, como observância ao princípio da equidade. Tem-se que a inclusão social das pessoas com deficiência no âmbito escolar - que não se limita a uma ou outra modalidade de ensino, mas engloba todas, da pré-escola ao ensino superior -, é elemento indispensável à construção de uma cidadania ativa, vez que a manutenção de uma escolarização nos moldes constitucionalmente pretendidos sugere a aderência dos alunos sem deficiência à inclusão do aluno com deficiência, sendo também essencial ao seu processo de conscientização sobre as diferenças.

Dessa forma, o objetivo deste trabalho é apresentar uma reflexão sobre a inclusão escolar da pessoa com deficiência em geral sob uma perspectiva dos direitos humanos, partindo-se do princípio de que a educação, associada aos procedimentos de inclusão social, é mecanismo central, senão suficiente, à provisão de uma cidadania nos moldes constitucional e convencionalmente pretendidos. Para a realização do trabalho, adota-se o método bibliográfico de abordagem, mediante revisão da literatura nacional e internacional, com tônica na produção acadêmica latino-americana, que tem fornecido significativas contribuições para se pensar as questões e os desafios que envolvem o direito à educação inclusiva.

\section{TUTELA JURÍDICA DO DIREITO À EDUCAÇÃO INCLUSIVA PARA PESSOAS COM DEFICIÊNCIA}

A reformulação dos meandros do sistema constitucional brasileiro a partir do final da década de oitenta representou a promessa à população de ampliação dos direitos fundamentais, a ponto de fazerem parte de uma sociedade que, revigorada com o término do regime ditatorial da história nacional e em franco período de transição no campo das filosofias sociais, prezasse pelos valores democráticos e carregasse consigo a bandeira da inclusão social e da promoção da diversidade, para introdução de grupos histórica e socialmente marginalizados nos projetos sociais.

O afastamento de um passado no qual a condição humana foi reduzida a um estado de miséria dos direitos humanos e fundamentais é marca de um novo ciclo que tem por escopo a tutela dos direitos das minorias e dos grupos vulneráveis. Embora pudesse simplesmente deixar a cargo do legislador infraconstitucional a nomeação desses grupos minoritários e vulneráveis, o constituinte preferiu ir além de mera enunciação de quem poderia ser considerado nesse aspecto de vulnerabilidade e trouxe normas específicas que visam a proteger integralmente as pessoas dos citados grupos, 
dentre as quais se destacam as pessoas com deficiência, conjunto de pessoas de reconhecida exclusão social histórica.

Essa perspectiva de concretização formal dos direitos das pessoas com deficiência, não deixando de lado as significativas contribuições que antecedem o período de promulgação da Constituição Federal brasileira, em 1988, teve sua principal projeção no campo do direito internacional na construção da Convenção Internacional sobre os Direitos das Pessoas com Deficiência. $O$ documento teve suas cláusulas normativas discutidas na cidade de Nova lorque, durante o ano de 2007, ao final sendo assinada pelo Estado brasileiro ainda no início do ano de promulgação.

No caso brasileiro em específico, o documento internacional protetivo dos direitos fundamentais das pessoas com deficiência representa verdadeira marca do novo constitucionalismo instaurado a partir da reformulação das bases constitucionais, vez que ganhou destaque no direito brasileiro após ser o primeiro tratado de direitos humanos aprovado sob o procedimento especial de internalização dos tratados e convenções internacionais que versem sobre direitos humanos. Cumpre-nos lembrar de que tal mecanismo foi instituído em 2004 pela emenda constitucional que reformou drasticamente as normas pertinentes ao Poder Judiciário, desde então tornando as normas convencionais equivalentes ao trazido pela Constituição Federal, sob a forma de emenda constitucional.

A principal contribuição da Convenção está em trazer uma perspectiva ampla e universal da tutela dos direitos das pessoas com deficiência, haja vista que não se limita a enunciar um ou alguns direitos, mas todos, da mesma forma que não se restringe a espécies específicas de deficiência, abarcando todas elas sob uma mesma filosofia protetiva. Com efeito, sua proposta de reconhecer direitos humanos de um grupo compreendido como vulneráveis e que esteve à frente de problemas sociais por décadas da história humana tem por finalidade ascender o grupo a ponto de possibilitar sua inclusão social.

Mais do que simplesmente arrolar direitos fundamentais das pessoas com deficiência, sob o aspecto da normatização, a Convenção "unifica em um documento internacional um feixe de direitos humanos reconhecidos a um grupo credor de direitos, as pessoas com deficiência" (MARTEL, 2011, p. 91). A partir de então, reafirma-se o caráter universalista dos direitos humanos mediante 0 reconhecimento das necessidades atinentes a direitos fundamentais individuais e sociais, de cunho majoritariamente coletivo, por que passam as pessoas com deficiência em sua tentativa de exercer os seus direitos em isonomia com os outros membros da sociedade.

No âmbito da legislação internacional, as deficiências assumem o caráter de "experiência de desigualdade compartilhada por pessoas com diferentes tipos de impedimentos" (MARTEL, 2011, p. 91), o que não deixa de 
fora os aspectos de transformação ocorridos no direito à educação, que ultrapassa a marca da educação integracionista para atingir o âmbito inclusivo, em que são respeitadas as diferenças de cada um e adaptando os serviços escolares às necessidades individuais, como medida de acessibilidade cultural e educacional propriamente dita para pessoas com deficiência em geral.

A ausência de professores e intérpretes capacitados para realização de atendimento individual e especializado ao aluno com deficiência nos espaços escolares brasileiros representa a negligência estatal frente às necessidades distintas dessas pessoas. Além disso, é patente a indiferença dos entes governamentais frente à necessidade de provimento de espaços que respeitem, ou seja, que estejam de acordo com os parâmetros normativos de acessibilidade arquitetônica para tais espaços, o que é regulamentado no direito brasileiro pelo Estatuto da Pessoa com Deficiência, de 2015, e antes pelas Leis n. 7.853/89 e 10.098/00, associadas à Norma Técnica ABNT NBR 9050/2004.

Segundo Romeu Sassaki (2008, p. 84-86), ainda se verificam falhas comunicacionais entre os sujeitos ativos e passivos do processo de ensino, além da recorrência de práticas discriminatórias negativas praticadas por outros alunos, com o revestimento das peculiaridades da intimidação sistemática (bullying), ou mesmo por profissionais pertencentes aos estabelecimentos de ensino. Tratam-se de barreiras sociais e técnicas que dificultam a inclusão desses alunos com deficiência no âmbito escolar comum.

Nesse sentido, aduz o professor:

A inclusão escolar é o processo de adequação da escola para que
todos os alunos possam receber uma educação de qualidade, cada
um a partir da realidade com que ele chega à escola,
independentemente de raça, etnia, gênero, situação socioeconômica,
deficiências etc. É a escola que deve ser capaz de acolher todo tipo
de aluno e de lhe oferecer uma educação de qualidade, ou seja,
respostas educativas compatíveis com as suas habilidades,
necessidades e expectativas (SASSAKI, 2008, p. 84).

Embora o senso comum recaia em erro terminológico e material, não se deve confundir os processos de integração e inclusão social, pois, enquanto o primeiro trata especificamente da adequação dos alunos com deficiência às estruturações físicas, curriculares e pedagógicas, administrativas, políticas e relacionais, o segundo requer um duplo esforço, que parte dos próprios alunos com deficiência, como atores de seu desenvolvimento social, e dos responsáveis pela colocação desses alunos em condições de igualdade para com os demais.

A respeito dessa diferenciação, explica o professor:

A integração trabalha com o pressuposto de que todos os alunos precisam ser capazes de aprender no nível pré-estabelecido pelo sistema de ensino. No caso de alunos com deficiência (intelectual, 
auditiva, visual, física ou múltipla), a escola comum condicionava a matrícula a uma certa prontidão que somente as escolas especiais (e, em alguns casos, as classes especiais) conseguiriam produzir (SASSAKI, 2008, p. 84).

Nos termos da Convenção, vê-se que é possível falar em uma plena inclusão social a partir do instante em que as barreiras sociais, arquitetônicas, comunicacionais e outras forem superadas com 0 desenvolvimento e a implementação de um plano de acessibilidade. A proposta deve levar em conta todos os aspectos da vida cotidiana desses indivíduos, para que sejam postos em evidência, pautados nos princípios de maior autonomia e independência das pessoas com deficiência, mesmo no âmbito escolar, perfazendo-se em uma questão típica de tutela dos direitos humanos das pessoas vulneráveis.

Por outro lado, a tutela dos direitos sociais fundamentais das pessoas com deficiência no sistema jurídico e político brasileiro foi reformulada a partir da entrada em vigor do Estatuto da Pessoa com Deficiência, a Lei $\mathrm{n}^{\circ}$. 13.146/15, que assevera ser a educação um direito dessas pessoas, sobretudo na forma de uma sistema educacional inclusivo que abranja todos os níveis de aprendizado. Ainda segundo a norma em vigor contemporaneamente, a finalidade da educação inclusiva é justamente possibilitar à pessoa com deficiência o desenvolvimento, no máximo grau possível, das habilidades e dos interesses pessoais desses indivíduos.

Ademais, tem-se que a efetivação do direito à educação inclusiva não é uma responsabilidade exclusiva do Estado, mas também abrange a família, a sociedade em geral - cuja atuação se traduz, em grande medida, na promoção dos direitos sociais pela sociedade civil organizada - e a própria comunidade escolar, que deve velar pelo processo de inclusão do aluno com deficiência em menor tempo e na maior qualidade possível. Especificamente ao Estado compete assegurar, desenvolver e acompanhar o sistema educacional inclusivo como um todo, nos muitos níveis e modalidades, tal como buscar aprimorar o projeto pedagógico que institucionalize 0 atendimento educacional especializado (BRASIL, 2015).

De fato, não se pode retirar a importância do movimento de normatização dos direitos sociais fundamentais das pessoas com deficiência, especialmente o direito à educação inclusiva. Todavia, ainda não se assiste uma esperada onda de efetividade no que tange a tais direitos, levando àquilo que dizia Norberto Bobbio (1992, p. 10):

A linguagem dos direitos tem indubitavelmente uma grande função prática, que é empresas uma força particular às reivindicações dos movimentos que demandam para si e para os outros a satisfação de novos carecimentos, materiais ou morais; mas ela se torna enganadora se obscurecer ou ocultar a diferença entre o direito reivindicado e o direito reconhecido e protegido. 
Significa dizer que, embora haja reconhecimento desses direitos por meio da positivação na ordem internacional e também doméstica, fato é que ainda se observam inúmeros desafios à sua efetivação. A partir de tais análises, resta claro e se torna possível dizer que o conteúdo jurídico básico dos direitos das pessoas com deficiência, mesmo a educação inclusiva, nada mais é senão a colocação em prática do princípio constitucional da igualdade, que preceitua a não introdução dessas pessoas em situações de discriminação, mas sim colocados em situação privilegiada frente às demais, como medida de inclusão social.

No campo do direito educacional inclusivo, especifica Vera Lúcia Flor Sénéchal de Godoffredo (1999, p. 45-46):

[...] o movimento pela sociedade inclusiva é internacional, e o Brasil está engajado nele, o que é no mínimo apropriado, já que temos cerca de 15 milhões de deficientes segundo a Organização das Nações Unidas (ONU), cuja grande maioria está, provavelmente, aguardando a oportunidade de participar da vida em sociedade, como é seu direito. Assim, necessitamos de uma nova escola que aprenda a refletir criticamente e a pesquisar. Uma escola que não tenha medo de se arriscar, com coragem suficiente para criar e questionar o que está estabelecido, em busca de rumos inovadores, e em resposta às necessidades de inclusão.

Dessa forma, traçam-se as primeiras linhas de uma educação inclusiva que se reveste de direito propriamente humano, como mecanismo de inclusão social e, consequentemente, de desenvolvimento humano das pessoas com deficiência. Além do mais, a educação inclusiva também é essencial para a construção de uma noção de cidadania, nos moldes constitucionalmente pensados, vez que possibilita a participação das pessoas com deficiência em importante aspecto da vida civil, essencial para a formação humana, que segue em tímidos passos, embora as manifestações dessa efetivação sejam notórias.

\section{DIREITOS HUMANOS E CIDADANIA: EDUCAÇÃO ESPECIAL E INCLUSÃO EM DEBATE}

Os direitos humanos devem ser compreendidos como aspectos essenciais à vivência humana e que acompanham cada indivíduo a partir do instante de seu nascimento, sem prejuízo de, em alguns casos, essa tutela humanística ocorrer antes mesmo da vinda ao mundo. A compreensão dos direitos humanos está intimamente relacionada à noção de condição humana, vez que o ser humano é o verdadeiro sujeito de tais direitos. A compreensão atual do conceito de direitos humanos se vincula à dinâmica empregada pelo constitucionalismo transnacional, que relaciona os direitos domésticos com os 
direitos internacionais (TEIXEIRA; KÖCHE, 2003). Nessa mesma perspectiva, os direitos da cidadania implicam fundamentalmente a ideia de que um indivíduo se encontra em relação com um sistema de regras universais. Conforme preleciona o sociólogo Roberto DaMatta (1997), a noção de cidadania constitui uma forma específica de pertencimento do indivíduo a uma dada totalidade social, de modo que atualmente as discussões sobre 0 conceito de cidadania têm se firmado nas dimensões política, jurídica, moral e sociológica.

Ao se apresentar a confluência dos temas de direitos humanos e direitos da cidadania, apresenta-se desde logo a questão da universalização do acesso à educação, tendo por enfoque as pessoas com deficiência, cuja proposta é justamente deixar o viés puramente heterogêneo e alcançar uma perspectiva de educação inclusiva e também participativa, de protagonismo da pessoa com deficiência. A questão da inclusão escolar não deve ser tratada como mera pretensão utópica do grupo vulnerável das pessoas com deficiência e de outros setores da sociedade que militam em prol dessas pessoas, mas sim uma construção que exige um processo coletivo, como engajamento da sociedade, da família, do ente estatal e, ainda mais, da comunidade escolar.

A educação em direitos humanos deve ser parte da formação de indivíduos que tenham dentre as características basilares o respeito à diversidade e carreguem consigo a proposta de inclusão social de alunos com as mais variadas deficiências. A propósito, "educar com princípios inclusivos também é característica de uma escola cidadã e preparada para receber qualquer tipo de aluno, ou seja, uma pessoa com ou sem deficiência" (MANICA; CALIMAN, 2015, p. 56), o que vale dizer que constitui verdadeiro direito-dever da escola contemporânea trazer em seu bojo aspectos de inclusão para as pessoas com deficiência, independentemente do grau que reveste a deficiência ou mesmo das dificuldades específicas de cada aluno.

Não se pode olvidar que a necessidade de uma educação inclusiva parte da adoção do modelo social de enfrentamento às questões das pessoas com deficiência ainda nos anos oitenta, sobretudo no âmbito do direito internacional, como meio de desafiar a normalidade presente no âmbito educacional. Inovando, a professora Agustina Palacios (2008, p. 382) tem defendido que a problemática da educação inclusiva beneficia todos os alunos, independentemente das limitações funcionais presentes nas pessoas com deficiência, vez que as necessidades especiais são observáveis em todo e qualquer aluno. A diferença existente em relação às pessoas com deficiência é que historicamente não se deu a devida atenção aos problemas e necessidades enfrentadas por tais pessoas no sistema educacional comum.

Foi a partir do modelo social que as necessidades educacionais das pessoas com deficiência foram levadas em consideração, sobretudo pelo fato de que, a partir de então, operou-se uma mudança no conceito de pessoa 
com deficiência e na própria efetivação de seus direitos fundamentais, que agora passam a ser não mais uma obrigação exclusiva dessas pessoas, mas sim de toda a sociedade, dotada do ônus de se adequar às exigências sociais do grupo em questão. Ou seja, trata-se de dizer que a mudança conceitual implicou o entendimento segundo qual nenhum aluno ou aluna deve ser forçado a se adaptar ao método educacional proposto, mas sim o oposto, a educação é o objeto que deve ser adaptado para atender às necessidades individuais e buscar o melhor interesse da pessoa com deficiência.

As pesquisas em direitos fundamentais das pessoas com deficiência têm demonstrado que os conceitos de inclusão e exclusão social são mutuamente incompatíveis, motivo pelo qual enquanto existir a segregação, a educação, definitivamente, não pode ser considerada inclusiva. Isso porque, atualmente se assiste a uma quase unanimidade de opiniões no âmbito acadêmico no que tange à construção de escolas específicas para pessoas com deficiência, que seriam denominadas "escolas de educação especial". Na verdade, a criação de ambientes escolares específicos para alunos com deficiência vai à contramão dos direitos humanos e da construção da cidadania para tais pessoas, vez que permite a marginalização de estudantes que possuem tais características, colocando-os à margem do ensino regular e asseverando a exclusão social. Até mesmo a Convenção Internacional sobre os Direitos das Pessoas com Deficiência busca extirpar essa percepção social, trazendo a pessoa com deficiência para o âmbito da escola comum, para que o aluno com deficiência possa se desenvolver junto a outros indivíduos.

Conforme posto pelo professor Luiz Alberto David Araújo (2015, p. 510), a educação inclusiva possui dupla faceta, pois a convivência com a diferença não é de fato direito apenas daqueles considerados diferentes, como as pessoas com deficiência, incluindo nesse aspecto um direito voltado propriamente à maioria, que se vê possibilitada de conviver com a minoria, de aprender sobre a tolerância e o humanismo como princípio de desenvolvimento social, e de promover a inclusão social e escolar dessas pessoas. Não por acaso hoje se assiste a um gradual crescimento no número de alunos com deficiência, que recebem a educação em todos os níveis de ensino na companhia de colegas de sala que não possuem qualquer tipo de deficiência.

Atualmente já se demonstra que ambientes educacionais que tenham por princípio a inclusão da pessoa com deficiência são deveras benéficos para a consolidação dos direitos humanos dos integrantes desse grupo e também para a reprodução do reconhecimento na sociedade contemporânea, caracterizada pela complexidade e pelas relações multifacetadas e diversificadas. Os alunos com deficiência que se encontram em espaços educacionalmente inclusivos estão mais propensos a desenvolver "habilidades em leitura e matemática, além de terem baixas ou nulas taxas de 
ausência da sala de aula e menores propensões a problemas comportamentais" (SPINIELI, 2018, p. 527). Além disso, também são beneficiários da educação inclusiva os próprios professores e administradores escolares, que se tornam aptos a pensar e desenvolver capacidades humanas úteis à superação de quaisquer preconceitos contra pessoas com deficiência que porventura ainda possam existir, enfatizando a ideia de recepção às diferenças.

Eis o acerto na afirmação segundo a qual a educação inclusiva é uma questão pertinente aos direitos humanos e aos direitos da cidadania, que servem de repositórios para o pensamento jurídico, social e político dessas reivindicações das minorias e grupos vulneráveis, além de funcionarem também como bases teóricas para promover a prática inclusiva das pessoas com deficiência. A função da escola é justamente servir de espaço para a edificação de conhecimentos sobre os direitos humanos e da cidadania, ao que não lhe é permitido escolher seus alunos ou mesmo assegurar a discriminação negativa em todas suas formas, mas sim ensinar na cidadania e na inclusão, promovendo o debate sobre a diversidade na convivência e que tenha por caminho a estruturação da sociedade livre, justa e solidária perquirida pelo constitucionalismo contemporâneo.

\section{CONSIDERAÇÕES FINAIS}

A formulação dos direitos humanos e dos direitos de cidadania nas últimas décadas encontra importantes precedentes no ordenamento jurídico pátrio, notadamente pela fixação da garantia de igualdade de condições para o acesso e permanência de todo e qualquer indivíduo no ambiente escolar, ao que desponta como notório instituto a educação inclusiva, conforme trabalhada pela Convenção Internacional sobre os Direitos das Pessoas com Deficiência, de 2008.

A inclusão social das pessoas com deficiência no âmbito escolar é elemento indispensável à construção de uma cidadania ativa, vez que a escolarização inadequada representa a manutenção do consolidado estado de violação sistemática dos direitos fundamentais desses indivíduos, tal como uma negação à dignidade humana e às normativas nacionais e internacionais. A ausência de uma educação inclusiva legitima distinções pessoais que se afiguram incompatíveis com a essência democrática e inclusiva adotada pela ordem constitucional brasileira e pelos documentos internacionais na matéria.

Dessa forma, conclui-se que a educação inclusiva objetiva contribuir para a extinção das violações de direitos humanos das pessoas componentes desse grupo e atingir o estado de cidadania constitucional. 


\section{REFERÊNCIAS}

ARAÚJO, Luiz Alberto David. Painel sobre a proteção das pessoas com deficiência no Brasil: a aparente insuficiência da Constituição e uma tentativa de diagnóstico. In: ROMBOLI, Roberto; ARAÚJO, Marcelo Labanca Corrêa de. (Orgs.). Justiça constitucional e tutela jurisdicional dos direitos fundamentais. Belo Horizonte: Arraes, 2015.

BOBBIO, Norberto. A era dos direitos. Rio de Janeiro: Campus, 1992.

BRASIL. Lei no. 13.146, de 6 de julho de 2015. Institui a Lei Brasileira de Inclusão da Pessoa com Deficiência (Estatuto da Pessoa com Deficiência). Disponível em: http://www.planalto.gov.br/ccivil_03/_ato20152018/2015/lei/l13146.htm. Acesso em 25 ago. 2019.

DAMATTA, Roberto. A casa e a rua: espaço, cidadania, mulher e morte no Brasil. 5. ed. Rio de Janeiro: Guanabara, 1997.

GODOFFREDO, Vera Lúcia Flor Sénéchal de. Educação: direito de todos os brasileiros. In: BRASIL. Ministério da Educação e Cultura. Salto para o futuro: educação especial. Brasília: Educação à distância, 1999.

MANICA, Loni Elisete; CALIMAN, Geraldo. A educação profissional para pessoas com deficiência: um novo jeito de ser docente. Brasília: Liber Livro, 2015.

MARTEL, Letícia de Campos Velho. Adaptação razoável: o novo conceito sob as lentes de uma gramática constitucional inclusiva. SUR Revista Internacional de Direitos Humanos, v. 8, n. 14, jun. 2011, p. 89-113.

PALACIOS, Agustina. El modelo social de discapacidad: orígenes, caracterización y plasmación en la Convención Internacional sobre los Derechos de las Personas con Discapacidad. Madrid: Grupo Editorial CINCA, 2008.

SASSAKI, Romeu Kazumi. Artigo 24 - Educação. In: RESENDE, Ana Paula C. de; VITAL, Flávia Maria de Paiva (Orgs.). A Convenção sobre os Direitos das Pessoas com Deficiência comentada. Brasília: CORDE, 2008. 
SPINIELI, André Luiz Pereira. A pessoa com deficiência e o direito constitucional à educação inclusiva. In: SGARBOSSA, Luís Fernando; IENSUE, Geziela (Orgs.). Direitos humanos e fundamentais. Campo Grande: Instituto Brasileiro de Pesquisa Jurídica, 2018, p. 509-532.

TEIXEIRA, Anderson Vichinkeski; KÖCHE, Rafael. Um direito sem Estado? Direitos humanos e a formação de um novo quadro normativo global. Revista de Direito Internacional, Brasília, v. 10, n. 2, p. 87-100, 2013. 


\title{
GERONTECNOLOGIA: O uso da tecnologia e a qualidade de vida de pessoas idosas
}

\author{
BULGO, Danilo Cândido \\ Mestrando - UNIFRAN \\ Docente - Educação à Distância da Universidade de Franca. \\ danilobulgo@gmail.com
}

GONÇALVES, Cristian Ribeiro Mestrando - Universidade de Franca cristianribeiro edfisica@hotmail.com

NASCIMENTO, Lilian Cristina Gomes do Docente - Universidade de Franca lilian.nascimento@unifran.edu.br

\section{INTRODUÇÃO}

O envelhecimento se consiste em um processo progressivo, dinâmico e irreversível, podendo ser entendido em múltiplas dimensões, o qual sofre influências de diversos fatores, tais como, estilo de vida, condições referente a aspectos biopsicossociais e espirituais (FECHINE; TROMPIERI, 2015).

De acordo com a Organização Mundial de Saúde (OMS) a terceira idade é a etapa do ciclo vital que se inicia aos 60 anos nos países em desenvolvimento, e aos 65 anos nos países desenvolvidos, sendo caracterizada por mudanças físicas que ocorrem no organismo, modificando funções e trazendo alterações no comportamento, percepção, sentimento, pensamento, ações e reações. Existe também alterações dos papéis sociais de cada indivíduo que derivam nas mudanças biopsicológicas relacionadas ao avançar da idade (OMS, 2005). Nesse contexto, as alterações morfológicas e funcionais relacionadas ao envelhecimento compõem uma das grandes preocupações para os profissionais da área da saúde, sobretudo no que se refere à melhora na qualidade de vida $(\mathrm{QV})$ e na prevenção de doenças $\mathrm{e}$ exclusão social (ROBERGS; ROBERTS, 2002).

No Brasil, dados do IBGE (2018) apontam que em 2050 serão mais de sessenta e seis milhões de pessoas idosas na população brasileira, ou seja, com aumento da longevidade e a diminuição da taxa de fecundidade, o Brasil passará a ter uma expressiva população idosa (BRASIL, 2018). Assim, diante do crescimento do número de indivíduos da população idosa, e do aumento da expectativa de vida, surgiu a necessidade de garantir maiores 
direitos a este público. Em acordo com os direitos previstos na Constituição Federal Brasileira de 1988, no ano de 1994 foi promulgada a Política Nacional do Idoso (PNI), Lei 8.842/94, a qual garante os direitos sociais à Pessoa Idosa, subsidiando condições para promover sua autonomia, integração e participação efetiva na sociedade

Com o avanço das tecnologias digitais e a utilização dos novos recursos advindos deste processo, torna-se cada vez mais presente na vida dos indivíduos os acessos aos meios digitais, tornando-se uma necessidade a inserção do idoso nesse novo paradigma social, pois os estimula a busca por novos conhecimentos e saberes sem deixar de lado os seus hábitos e costumes, além de ser uma ferramenta que pode empoderar a prática por novas habilidades a serem aprendidas, proporcionando assim inserção no mundo globalizado e na Era Digital. O desenvolvimento das tecnologias e do mundo da informação digital é uma constante nas sociedades modernas (TREDINNICK, 2008).

Ao abordar questões relacionadas entre o envelhecimento e o uso das novas tecnologias digitais, como computadores, celulares e internet, a literatura aponta que a terceira idade é a parcela da população que menos utiliza tais tecnologias. Entretanto, ao abordar o processo de envelhecimento, esse perfil populacional é considerado um grupo etário que muito se beneficiaria da sua utilização, quando se pensa nos potenciais compensatórios dos recursos tecnológicos frente aos efeitos deletério do avançar da idade e das diversas possibilidades de otimização do potencial de crescimento e aprendizado na terceira idade (KACHAR, 2010).

A tecnologia está cada vez mais presente, direta e indiretamente, na vida cotidiana dos idosos, sendo utilizada e explorada como instrumento de trabalho, de lazer, de busca ou fornecimento de informações, contribuindo para o advento de uma maneira inovadora de apropriar-se, adquirir e comunicar a informação (SANTOS, et. al, 2018).

Segundo Santos e Oliveira (2017) "não ter acesso e ser capaz de usar a tecnologia cada vez mais colocará os idosos em desvantagem em termos de sua capacidade de viver e funcionar independentemente".

A tecnologia e o acesso no universo digital também representam um mecanismo para o alcance de metas estabelecidas na Agenda 2030, documento que tem como escopo principal a composição de 17 Objetivos de Desenvolvimento Sustentável (ODS). O ODS 9 visa em sua essência "construir infraestruturas resilientes, promover a industrialização inclusiva e sustentável e fomentar a inovação" destacando no item 9.c "Aumentar significativamente o acesso às tecnologias de informação e comunicação e se empenhar para procurar ao máximo oferecer acesso universal e a preços acessíveis à internet nos países menos desenvolvidos, até 2020" (ONU, 2015). 
$\mathrm{Na}$ atualidade, as tecnologias digitais têm trazido várias transformações no que diz respeito a inserção dos indivíduos na sociedade moderna, sendo possível até mesmo o aumento da socialização entre as pessoas por meio de dispositivos de informação e comunicação, como o computador, o celular e a internet (RECUERO, 2009).

Esse progresso referente aos recursos de comunicação aconteceu de maneira rápida, se comparado a outros dispositivos como o rádio ou televisão, e com a chegada dos sites possibilitou-se a comunicação e conexão rápida entre os diferentes grupos populacionais, porém como um meio paradoxal reforçou mais essa realidade de interação a distância que envolve nossa sociedade (MATA, 2012).

Esses novos meios comunicacionais se tornam então a evolução de um conceito humano chamado de redes sociais, e sua modernização se tornou responsável por grandes transformações advindas no contexto sócio comunicativo que permeia a sociedade. Redes sociais podem ser descritas como qualquer lugar onde dois ou mais indivíduos mantêm uma inter relação entre si. Esta terminologia é utilizada para indicar plataformas virtuais e páginas online que por meio do uso de tecnologias conectadas à Internet, seus usuários criam grupos de conversas onde trocam mensagens, fotos, áudios, vídeo chamadas e compartilham ideias e informações (CRUZ et al., 2017).

Nessa perspectiva destaca-se o conceito de promoção de saúde (PS), que surge como um conjunto de estratégias e formas de produzir saúde, tanto no âmbito individual como no coletivo, tendo como objetivo de atender às necessidades sociais de saúde e garantir a melhoria da qualidade de vida da população (MALTA, 2016).

Assim, ao abordar os conceitos de PS, desenvolveu-se um novo modelo de saúde, no qual o indivíduo participa ativamente no processo de PS, por meio da adoção de comportamentos e atitudes que a promovam, sendo essa também responsabilidade dos indivíduos, atores essenciais para transformação de hábitos e estilos de vida pouco saudáveis para atingir melhores níveis em saúde (FELIPE, 2011).

Consoante ao exposto, o presente trabalho tem por objetivo, verificar o uso de tecnologia e a auto percepção de qualidade de vida de pessoas idosas.

\section{METODOLOGIA}

Trata-se de um trabalho de cunho quantitativo, observacional e de corte transversal. A seleção da amostra foi realizada por meio da amostragem não-probabilística por acessibilidade. Participaram do presente estudo 290 idosos que atenderam aos seguintes critérios de inclusão: ter 60 anos de idade 
ou mais, ambos os sexos, residentes em uma cidade específica do interior do estado de São Paulo, que aceitaram responder todo questionário após assinar o Termo de Consentimento Livre e Esclarecido (TCLE). Foram excluídos do estudo: pessoas idosas com algum tipo de comprometimento físico e/ou cognitivo que o impossibilitaria em responder os questionários, que se recusaram a assinar o TCLE, que estavam de passagem na cidade (visitando familiares ou a passeio), residentes na zona rural da cidade, institucionalizados e/ou hospitalizados.

Quanto aos aspectos éticos, conforme Resolução № 466/2012, do Conselho Nacional de Saúde em Pesquisa, envolvendo seres humanos, este projeto foi encaminhado para apreciação do Comitê de Ética em Pesquisa da Universidade de Franca (UNIFRAN) e aprovado sob CAAE no 00688218.0.0000.5495. Para a coleta de dados, foi aplicado um questionário com perguntas abertas de cunho sociodemográfico o qual objetiva conhecer o perfil e descrever as características acerca da amostra do estudo como, sexo, idade, estado civil, nível de escolaridade, condições da moradia; uma pergunta sobre a sua saúde e sobre sua qualidade de vida; e ainda perguntas sobre 0 uso da tecnologia Faz uso de tecnologias? Tem medo de utilizar tecnologias? Possui Rede Social? Qual rede social utiliza?

\section{RESULTADOS E DISCUSSÃO}

Participaram do presente estudo 290 idosos, com idade entre $60 \mathrm{e}$ 99 anos. Na Tabela 1, encontra-se descrito as variáveis sociodemográficas dos participantes.

Tabela 1 - Perfil Sócio demográfico

\begin{tabular}{llcc}
\hline \multicolumn{1}{c}{ Variações } & \multicolumn{1}{c}{ Categorias } & F & $\%$ \\
\hline Número de participantes & \multicolumn{1}{c}{. } & 290 & 100 \\
\hline \multirow{2}{*}{ Sexo } & Feminino & 151 & 52,07 \\
& Masculino & 139 & 47,93 \\
\hline \multirow{5}{*}{ Idade } & 60 anos & 44 & 15,2 \\
& Entre 61 e 69 anos & 131 & 45,2 \\
& Entre 70 e 79 anos & 77 & 26,6 \\
& Entre 80 e 89 anos & 35 & 12 \\
& Entre 90 e 99 anos & 3 & 1 \\
& & & \\
\hline \multirow{5}{*}{ Estado civil } & Solteiro(a) & 16 & 5,5 \\
& Vive com o(a) & 19 & 6,6 \\
& Companheiro(a) & 164 & 56,5 \\
& Casado(a) & 53 & 18,3 \\
\hline
\end{tabular}




\begin{tabular}{llcc} 
& Separado(a) & 7 & 2,4 \\
& Divorciado(a) & 26 & 9 \\
Namorando & 5 & 1,7 \\
& & & \\
\hline \multirow{5}{*}{ Escolaridade } & Analfabeto & 5 & 1,7 \\
& Fundamental Incompleto & 68 & 23,5 \\
& Fundamental Completo & 54 & 18,6 \\
& Médio Incompleto & 21 & 7,2 \\
& Médio Completo & 43 & 14,9 \\
& Técnico & 16 & 5,5 \\
& Superior Incompleto & 12 & 4,1 \\
Moradia & Superior Completo & 42 & 14,5 \\
& Pós-graduação Completa & 26 & 9 \\
& Mestrado & 3 & 1 \\
& & & \\
\hline & Própria & 245 & 84,5 \\
& Alugada & 32 & 11 \\
& Cedida & 13 & 4,5 \\
& & &
\end{tabular}

Fonte: dados da pesquisa. $\mathrm{F}$ = frequência; $\%=$ percentual

O fato da proporção de participantes do sexo feminino ser maior do que do sexo masculino era esperado. Assim como se aponta no trabalho de Freitas et al. (2017), que avaliaram a relação da qualidade de vida com o estado nutricional de idosos e cuja amostra foi composta na sua maioria por mulheres $(65,6 \%)$. Tal preponderância é apontada pelo censo do Instituto Brasileiro de Geografia e Estatística (IBGE, 2011) tanto para o estado de São Paulo, quanto para o município onde foi realizada a pesquisa.

Com relação a análise do estado de saúde, qualidade de vida e estado emocional foram aplicadas questões utilizando a escala Likert, a fim de promover a resposta pelos participantes. Dessa forma, a maioria classifica seu estado de saúde como predominante bom, a qualidade de vida como boa e se considera uma pessoa muito feliz (Tabela 2).

Tabela 2 - Análise do estado de saúde, qualidade de vida e estado emocional.

\begin{tabular}{llcc}
\hline \multicolumn{1}{c}{ Variações } & \multicolumn{1}{c}{ Categorias } & F & $\%$ \\
\hline & Muito ruim & 1 & 0,3 \\
& Ruim & 8 & 2,8 \\
Saúde & Nem boa nem ruim & 54 & 18,6 \\
& Boa & 166 & 57,3 \\
& Muito boa & 61 & 21 \\
\hline \multirow{2}{*}{ Qualidade de Vida } & Muito ruim & 1 & 0,3 \\
& Ruim & 5 & 1,7 \\
\hline
\end{tabular}




$\begin{array}{lcc}\text { Nem boa nem ruim } & 48 & 16,6 \\ \text { Boa } & 166 & 57,3 \\ \text { Muito boa } & 70 & 24,1\end{array}$

$\mathrm{F}=$ frequência; \% = percentual

A OMS conceitua qualidade de vida (QV) como sendo a "percepção do indivíduo sobre a sua posição na vida, dentro do contexto de sistemas de cultura e valores nos quais está inserido e em relação aos seus objetivos, expetativas, padrões e preocupações" (WHO, 1997, p.1).

O conceito de QV está relacionado à autoestima e ao bem-estar individual ampliando a conceituação para diversos aspetos como a capacidade funcional, o nível socioeconômico, estado emocional, interação social, atividade intelectual, autocuidado, suporte familiar, o próprio estado de saúde, os valores culturais, éticos e a religiosidade, o estilo de vida, a satisfação com emprego e/ou com atividades diárias e o ambiente em que se vive (VECCHIA et al., 2005).

Tal afirmação vai ao encontro com as informações obtidas com os participantes do presente capítulo, pois ao serem questionados sobre sua QV, 166 idosos $(57,3 \%)$ relataram ter uma boa QV, seguido de "muito boa" $(24,1 \%)$. Sobre aspectos de felicidade 109 idosos $(37,6 \%)$ se consideram "muito feliz", seguindo de 100 idosos (34,5\%) apontando se sentirem "bastante feliz".

A avaliação da qualidade de vida para o Whoqol Group é subjetiva que une o contexto cultural social e ambiental. Assim, e por multidimensional, não abarca exclusivamente a saúde física do indivíduo, mas também o seu estado psicológico, o seu nível de dependência, as suas relações sociais estabelecidas, bem como as suas relações afetivas e o ambiente em que vive (CANAVARRO, 2010).

À medida que o indivíduo envelhece, a sua $Q V$ é determinada não só pela capacidade de manter autonomia, mas também pela capacidade de manter sua independência, pois, a autonomia motiva a habilidade que 0 indivíduo tem para controlar, lidar e tomar decisões sobre como deve viver diariamente, de acordo com as suas regras e preferências; enquanto a independência se refere à capacidade que pessoa tem para efetuar funções relacionadas com a vida diária (DALSENTER; MATOS, 2009).

$\mathrm{Na}$ avaliação da qualidade de vida do idoso é importante ressaltar a complexidade da tarefa e a adoção de múltiplos critérios de natureza biológica, psicológica e sociocultural, vários elementos são considerados como determinantes ou indicadores de bem-estar na velhice: longevidade, saúde biológica, saúde mental, satisfação, controle cognitivo, competência social, produtividade, atividade, eficácia cognitiva, "status" social, renda, continuidade 
de papéis familiares, ocupacionais e continuidade de relações informais com amigos (NERI, 1993).

Com o crescimento do número de idosos no cenário brasileiro, o país vive um momento de transformação onde a realidade da pessoa idosa no país tende a se tornar cada vez mais o foco frente as transformações sofridas por este grupo ao longo dos anos. Segundo dados do IBGE (2018), por meio da Pesquisa Nacional por Amostras de Domicílios Continua (PNAD), em 2012 o número de idosos era de $12,8 \%$ da população total de indivíduos do Brasil, um número que aumentou para $14,6 \%$ no ano de 2017 , apontando que o país ganhou mais 4,8 milhões de idosos em apenas 5 anos (DELLARMELIN; BALBINOT; FROEMMING, 2017).

Já em relação à tecnologia e redes sociais, Kenski (2008, p.15), as tecnologias são tão antigas quanto a espécie humana. Na verdade, foi a engenhosidade humana, em todos os tempos, que deu origem às mais diferenciadas tecnologias. Segundo os estudos de Páscoa e Gil (2015), a terceira idade tem usado o Facebook por ser uma ferramenta facilitadora de socialização e auxílio na redução da sensação de abandono, promovendo a comunicação com familiares, especialmente os netos, onde o diálogo efetuado por meio desse mecanismo ajuda o idoso a manter uma conversa com seu familiar. Na tabela 3, pode-se verificar se os participantes faziam uso de tecnologia, se sentem medo de utilizar tecnologia e se possuíam rede social.

Tabela 3 - Utilização da tecnologia e rede social

\begin{tabular}{|c|c|c|c|}
\hline Variações & Categorias & $\mathbf{F}$ & $\%$ \\
\hline Número de participantes & & 290 & 100 \\
\hline \multirow{2}{*}{ Uso de tecnologias } & Sim & 234 & 80,7 \\
\hline & Não & 56 & 19,3 \\
\hline \multirow{3}{*}{ Medo de utilizar tecnologias } & Sim & 150 & 51,7 \\
\hline & Não & 140 & 48,3 \\
\hline & Sim & 163 & 56,2 \\
\hline Possui Rede Social & Não possuo & 127 & 43,8 \\
\hline
\end{tabular}

\begin{tabular}{llcc}
\hline & Facebook & 159 & 97,5 \\
& Instagram & 75 & 46 \\
& Skype & 24 & 14,7 \\
& Twitter & 12 & 7,4 \\
Rede Social que utiliza & Linkedin & 8 & 4,9 \\
& Salas de bate papo/ & 7 & 4,3 \\
& aplicativos de paquera & & 14,1 \\
\hline
\end{tabular}


$f=$ frequência; $\%$ = percentual

Essa procura pelo universo virtual pode ser notada nos resultados de uma pesquisa realizada pelo Serviço de Proteção ao Crédito (SPC Brasil) e a Confederação Nacional de Dirigentes Lojistas (CNDL), onde apontou posteriormente que a grande parte dos idosos entrevistados são motivados a utilizarem as redes sociais digitais para manter contato com seus amigos (76,5\%) e familiares $(75,6 \%)$.

Ainda conforme apresentado na Tabela 3 , quanto à utilização de redes sociais o número de idosos que possuem acesso a essas ferramentas se mostram parcialmente alto, apontando que 163 idosos (56,2\%) relataram acessar redes sociais. Porém, mesmo essa alta taxa de crescimento sendo um fator positivo de um ponto de vista referente a qualidade de vida humana, é inerente destacar que 0 rápido desenvolvimento dos recursos tecnológicos trouxe também dificuldades para a realidade do idoso: a exclusão digital. Acostumados a uma tecnologia integralmente analógica, a passagem histórica que marcou a mudança das tecnologias para a digital forçou o idoso a construir novas habilidades para lidar com essas ferramentas.

Conforme pode ser identificado na Tabela 3 , os participantes desta pesquisa evidenciaram usar tecnologia 234 idosos $(80,7 \%)$, porém corroborando com as pesquisas 150 idosos $(51,7 \%)$ relataram ter medo de usar meios advindos da tecnologia no seu dia a dia, dado preocupante, pois isso pode acontecer, devido à modernização da sociedade, visto que em muitos casos suas experiências tornaram-se ineficazes ao lidarem com as tecnologias digitais atuais, que vão desde aparelhos celulares com funções acionadas por toques autoatendimento bancário. Então mais do que adaptar-se a uma nova realidade, os idosos precisam reaprender a utilizar os novos mecanismos para conseguirem manuseá-los (FARIAS et al., 2015).

Essa dificuldade não é a única enfrentada por esse grupo, mais do que reaprender, eles ainda enfrentam o medo, o preconceito, e a diminuição das capacidades sensoriais e motoras. Essa realidade tira da população idosa muitas oportunidades, visto que as novas tecnologias da informação e comunicação trouxeram muitos benefícios ao cotidiano das pessoas, como a melhora na realização das atividades dos indivíduos, a simplificação de problemas e o aumento na expectativa de vida (BOTELHO, 2013).

Essa característica de aproximar o idoso das pessoas de quem ele sente afeto, os assegura mais do que a possibilidade de interação, Ihes proporciona uma melhora na qualidade de vida, e atualmente isto está se tornando possível graças as redes sociais digitais. Com o fácil acesso a esta tecnologia, barreiras geográficas sendo quebradas e a Internet com sua característica de disseminação de informação, tornou o seu uso um importante 
aliado na saúde mental e social, sendo as redes sociais um influenciador da criatividade e aprendizado intelectual do idoso (CRUZ et al., 2017).

Os idosos veem neste espaço um local para socializar-se com seus amigos e familiares, ajudando na comunicação de modo a diminuir o sentimento de solidão e isolamento, contribuindo também como estimulante mental e na qualidade de vida (KREIS et al., 2007).

Segundo o trabalho realizado por Carleto e Santana (2017), a terceira idade que têm utilizado as tecnologias digitais no contato socioafetivo com os mais jovens, tendo como principal elemento tecnológico o uso do telefone celular, e que a finalidade do uso é manter aproximação com os familiares, a fim de estreitar laços afetivos. A família pode ser o elo entre a aprendizagem e a tecnologia na terceira idade, pois os idosos sentem confiança e amabilidade quando aprendem algo advindos dos conhecimentos de seus familiares o que implica diretamente com fatores da PS.

\section{CONSIDERAÇÕES FINAIS}

O termo gerontecnologia visa contribuir para a evolução dos aspectos da pessoa idosa aos meios digitais e tecnológicos o que na era contemporânea se destaca como uma ferramenta dinâmica. No presente trabalho percebeu-se que a maioria dos idosos entrevistados fazem uso de tecnologia e redes sociais, o que corrobora de maneira positiva a relação da terceira idade com a tecnologia digital, permitindo que os mesmos se comuniquem, estabelecendo assim, aproximação com familiares e amigos, o que promove o aumento na qualidade de vida e diminui o isolamento social.

Ao utilizar redes sociais e tecnologias pode-se observar a promoção da autonomia e melhora na autoestima dos idosos, o que pode corroborar para uma vida com melhor qualidade. Faz-se necessário novas pesquisas que abranja os aspectos da gerontecnologia a fim de compreender melhor as relações intergeracionais dos idosos e a utilização de recursos tecnológicos. Dessa forma, será possível propor diferentes alternativas que visem a inclusão da pessoa idosa no mundo tecnológico de maneira que se sintam pertencentes a ele, e não mais excluídos evitando assim o fenômeno de infoexclusão.

\section{REFERÊNCIAS}

BOTELHO, L. F. Inclusão digital para a melhor idade: Desafios. In: CONGRESSO NACIONAL DE INICIAÇÃO CIENTÍFICA, 13, 2013, Campinas. Anais... Campinas: SEMESP. 2013. 
CANAVARRO, M. C. (2010). Qualidade de Vida: Significados e Níveis de Qualidade de Vida e Saúde: Uma Abordagem na Perspectiva da Organização Mundial de Saúde. Lisboa: Fundação Calouste Gulbenkian

CARLETO, D. G.; SANTANA, C. S. (2017, janeiro-março. Relações intergeracionais mediadas pelas tecnologias digitais. Revista Kairós Gerontologia, 20(1), pp. 73-91.

CRUZ, A. et al. Consumo das redes sociais digitais pela terceira idade. In: CONGRESSO BRASILEIRO DE CIÊNCIAS DA COMUNICAÇÃO, 40, 2017, Curitiba. Anais... Curitiba: Sociedade Brasileira de Estudos Interdisciplinares da Comunicação, 2017. p. 1-14.

DALSENTER, C. A.; MATOS, F. M. Percepção da qualidade de vida de idosos institucionalizados da cidade de Blumenau (SC). Dynamis, v. 15, n. 2, p. 3237, 2009.

DELLARMELIN, M. L.; BALBINOT, V. A.; FROEMMING, L. M. S. Análise do comportamento e utilização das redes sociais pelos idosos. Sociais e Humanas, [s.I.], v. 30, n. 1, p. 174-184, 27 jun. 2017.

FARIAS, J. S. et al. Inclusão digital na terceira idade: um estudo sobre a propensão de idosos à adoção de tecnologias da informação e comunicação (TICs). Gestão \& Tecnologia, v. 15, n. 3, p. 164-188, set./dez. de 2015.

FECHINE, B. R. A.; TROMPIERI, N. O processo de envelhecimento: as principais alterações que acontecem com 0 idoso com 0 passar dos anos. InterSciencePlace, v. 1, n. 20, 2015.

FLECK, M. P.; CHACHAMOVICH, E.; TRENTINI, C. Development and validation of the Portuguese version of the WHOQOL-OLD module. Revista de Saúde Pública, São Paulo, v. 40, n. 5, p. 785-791, out. 2006.

KACHAR, V. Envelhecimento e perspectivas de inclusão digital. Revista Kairós: Gerontologia, v. 13, n. 2, 2010.

KENSKI, V. M. Tecnologias E Ensino Presencial E A Distância. Campinas, SP: Papirus, 2008.

KREIS, R. A. et al. O impacto da informática na vida do idoso. Kairós Gerontologia, São Paulo, v. 10, n. 2, p. 153-168, dez. 2007.

NAÇÕES UNIDAS NO BRASIL- ONU BR. A Agenda 2030. Disponível em :< https://nacoesunidas.org/pos2015/agenda2030/ >. Acesso em: 13 de agosto de 2019

NERI, A. L. Qualidade de vida e idade madura. Papirus editora, 1993.

ORGANIZAÇÃO MUNDIAL DE SAÚDE (OMS). Envelhecimento ativo: uma política de saúde. Brasília: Organização Pan-Americana da Saúde. 2005. 
PÁSCOA, G. M. G.; GIL, H. M. P. T. Uma nova forma de comunicação para o cidadão Sénior: Facebook. Revista Kairós Gerontologia, São Paulo (SP), vol. 18, n. 1, p. 9-29, mar. 2015

RECUERO, R. Redes Sociais na Internet. Porto Alegre: Sulina, 2009, 191 p.

ROBERGS, R.A; ROBERTS S.O. Princípios fundamentais de fisiologia do exercício para aptidão, desempenho e saúde.1.ed. São Paulo:Phorte, 2002.

SANTOS, A. A. S. et al. A importância do uso de tecnologias no desenvolvimento cognitivo dos idosos. Gep News, v. 1, n. 1, p. 20-24, 2018.

TREDINNICK, L. (2008). Digital Information Culture. Estados Unidos: Elsevier Chandos Publishing.

VECCHIA, R. D. et al. Qualidade de vida na terceira idade: um conceito subjetivo. Revista brasileira de epidemiologia, v. 8, p. 246-252, 2005.

WHO. World Health Organization. Global recommendations on physical activity for health. Genebra: WHO, 1997. Disponível em: <https://www.ncbi.nlm.nih.gov/books/NBK305057/>. Acesso em: 09 agosto de 2019. 


\title{
HISTÓRIA DA EDUCAÇÃO ESPECIAL NO BRASIL
}

\author{
ANDRADE, Amanda Gonçalves de \\ Discente -UNESP \\ MARTINO, Vânia de Fátima \\ Docente - UNESP
}

\section{INTRODUÇÃO}

Este projeto tem por objeto de estudo a História da Educação Especial no Brasil, levando em conta suas diferentes transformações e implicações nas políticas públicas educacionais e principalmente nos processos de formação educacional da sociedade brasileira cujos envolvidos são os alunos portadores necessidades especiais, termo recentemente utilizado pelos pesquisadores e pela sociedade em geral.

$\mathrm{Na}$ Antiguidade, os deficientes eram abandonados, perseguidos e eliminados devidos às suas condições desde o nascimento, a infância não possuía esse conceito que é idealizado em nossa sociedade como é agora, essas crianças com deficiência na antiguidade não eram vistas como pessoas, uma vez que não passaram pelos mecanismos de integração à família e à cidade, a maioria dos bebes morriam logo após o nascimento, antes que a cerimonia que acontecia geralmente dez dias depois do nascimento os integrassem na comunidade.

$\mathrm{Na}$ Idade Média, as pessoas encaravam a deficiência como um castigo de Deus, as pessoas supersticiosas viam nelas poderes especiais de feitiçaria, ocorriam também a concepção de caridade dependia da comunidade onde estavam inseridos, as crianças que sobreviviam eram separadas de suas famílias, causando a exclusão na sociedade.

A idade moderna marcou o período do nascer de novas ideias, 0 século XVI, com o Renascentismo das artes, da música e das ciências, traziam transformações, marcado pelo humanismo, o interesse da ciência, especialmente da medicina.

Durante o século XVII e XVIII ocorreu grandes transformações no atendimento às pessoas com deficiência em hospitais, havia agora assistência para pessoas cegas e surdas. No século XIX, ainda com os reflexos da Revolução Francesa, agora as pessoas com deficiência também tinham uma atenção especializada, começam a realizar organizações para estudar os problemas de cada deficiência, difundia-se orfanatos, asilos e lares para crianças com deficiência física.

No Brasil essas mudanças ocorreram pelo Imperador Dom Pedro II, seguindo o movimento europeu, foi assim criado a Imperial Instituto dos 
Meninos Cegos, atualmente Instituto Benjamin Constant, por meio do Decreto Imperial $\mathrm{n}^{0}$ 1.428, de 12 de Setembro de 1854. Em 26 de setembro de 1857, o Imperador apoio as ideias de Professor francês Hernest Huet e fundou 0 Imperial Instituto de Surdos Mudos, atualmente Instituto Nacional de Educação de Surdos - INES, que passa a atender pessoas surdas de todo o país, a maioria era abandona por suas famílias.

No século $X X$, surge o desenvolvimento de escolas e classes especiais em escolas públicas, oferecendo uma educação à parte para a pessoa deficiente, passa-se a ser realizado um movimento de integração social em ambientes escolares, o mais semelhante possível aquele oferecido à pessoa normal.

Neste sentido, este trabalho propõe, ao longo de suas análises, um breve resgate da História da Educação Especial, com ênfase na concepção de inclusão educacional criada no final do século $X X$ e principalmente na primeira década do século XXI. Nosso olhar debruça-se nos processos de inclusão do aluno especial, levando em conta, como as mudanças ocorridas nos últimos anos implicaram, não apenas, na abordagem e no desenvolvimento de ações, materiais, cursos, mas principalmente na forma como a educação escolar tem pensado a questão da educação especial em suas distintas formas.

O primeiro passo para a concepção de inclusão especial no sistema educacional foi o Decreto $n^{\circ}$ 3.956, de 8 de outubro de 2001, com o qual o Brasil promulga a Convenção Interamericana para Eliminação de todas as Formas de Discriminação contra as Pessoas Portadoras de Deficiência. Realizado em 1999, o evento ficou conhecido como Convenção da Guatemala.

Esse documento do Decreto da convenção da Guatemala tem tanto valor como uma lei ordinária, já que garante os direitos fundamentais do ser humano:

Sua importância está no fato de que deixa clara a IMPOSSIBILIDADE de diferenciação com base na deficiência, definindo a discriminação como toda diferenciação, exclusão ou restrição baseada em deficiência, antecedente de deficiência presente ou passada, que tenha o efeito ou propósito de impedir ou anular o reconhecimento, gozo ou exercício por parte das pessoas portadoras de deficiência de seus direitos humanos e suas liberdades fundamentais (art. I, $\mathrm{n}^{\circ} 2$, "a"). (BRASIL. [Constituição (1988)]. Constituição da República Federativa do Brasil de 1988. Brasília, DF: Presidência da República, [1988]. Disponível em: https://www.senado.leg.br/atividade/const/con1988/CON1988_05.10. 1988/art_5_asp. Acesso em: 12 jun. 2019.

A educação na Constituição Brasileira visa o desenvolvimento humano e o seu preparo para o exercício da cidadania (art.205), qualquer que seja a restrição existente a um ambiente marcado pela diversidade, negando assim a formação do cidadão, negaria "em si mesma o direito à igualdade dessas pessoas". (BRASIL. [Constituição (1988)]. Constituição da República Federativa do Brasil 
de 1988. Brasília, DF: Presidência da República, [1988]. Disponível em:

https://www.senado.leg.br/atividade/const/con1988/CON1988_05.10. 1988/art_5_asp. Acesso em: 12 jun. 2019.)

No Art. $20 \overline{8}$. O dever do Estado com a educação será efetivado mediante a garantia que consta no inciso III- atendimento educacional especializado aos portadores de deficiência, preferencialmente na rede regular de ensino (BRASIL. [Constituição (1988)]. Constituição da República Federativa do Brasil de 1988. Brasília, DF: Presidência da República, [1988]. Disponível em: https://www.senado.leg.br/atividade/const/con1988/CON1988_05.10. 1988/art_5_.asp. Acesso em: 12 jun. 2019.)

Entendemos para que funcionem efetivamente as medidas sediadas pela constituição federal é necessário que os estabelecimentos de ensino eliminem barreiras e adotem métodos e práticas adequados as diferenças e necessidades de seus alunos em geral, contribuindo assim para a melhoria dos processos de ensino e aprendizado dos educandos com e sem deficiência, sem discriminações pela diversidade.

A inclusão no ensino regular rompe o conservadorismo das escolas, contestando os sistemas educacionais e sua fundamentação de ensino. Ela realiza o questionamento na metodologia de ensino, nos perfis específicos do educando até mesmo na formação contínua do professor que precisa estar apto para trabalhar as diversidades na sala de aula, produzindo assim identidades e diferenças de seus alunos, inserção ou exclusão dos mesmos.

As escolas até o marco da Politica Nacional de Educação Especial na Perspectiva da Educação Inclusiva (2008) foi importante para colocar fim na separação das escolas normais e especiais, determinando normais para crianças da escola comum e especiais para alunos que tendem a precisar de mais atenção voltado para suas diferenças.

Os indivíduos com deficiência, eram vistos como incapazes, sempre estiveram em posição desvantajosa, no imaginário coletivo, uma posição inferior que precisava de caridade popular e da assistência social, e não como sujeitos integrados na sociedade, que merecem o direito à educação. Ainda hoje, ainda existe a dificuldade de aceitação da família e do social, principalmente do portador que apresenta deficiências múltiplas e graves, que na escolarização requer mais atenção na aprendizagem.

$\mathrm{Na}$ tentativa de eliminar os preconceitos e integrar esses alunos portadores de deficiência nas escolas comuns, surgiu o movimento de integração escolar. Esse movimento caracterizou-se de no início pela utilização das classes especiais na preparação do aluno para integração total na classe comum, o aluno tinha que se adequar à escola que se mantinha inalterada para receber aquela criança. A integração total só era permitida para alunos que conseguissem acompanhar o currículo ali desenvolvido, este processo, 
portanto, impedia que a maioria das crianças, jovens e adultos com necessidades especiais alcançassem os níveis mais elevados de ensino, engrossando assim a base da pirâmide dos excluídos do sistema educacional.

A educação tem hoje, um grande desafio de garantir o acesso aos conteúdos básicos que a escolarização deve proporcionar a todos os indivíduos, inclusive com necessidades educacionais especiais, sendo eles com alta habilidades, precocidade, superdotação, condutas típicas de síndromes, neurológicos ou psiquiátricos; portadores de deficiências, ou seja, alunos que apresentam significativas diferenças físicas, sensoriais ou intelectuais, decorrentes de fatores genéticos, inatos ou ambientas, de caráter temporário ou permanente e que, em interação dinâmica com fatores socioambientais, resultam em necessidades muito diferenciadas da maioria das pessoas.(BRASIL. Ministério da Educação. Diretrizes nacionais para a educação especial na educação básica / Secretaria de Educação Especial - MEC; SEESP, 2001)

Os ambientes escolares inclusivos são importantes para a valorização das diferenças, respeito entre as crianças, são fundamentados na concepção de identidade que essas crianças estão formando desde pequenos, como a tolerância e respeito pelas particularidades de cada um, não havendo, nestes ambientes uma norma privilegiada de identidade em relação as demais.

Nos ambientes escolares excludentes, à valorização da "identidade normal" sobrepondo aos que não se encaixam, criando assim um ambiente hostil que não aceita as diferenças e dificulta na formação de identidade da criança e no seu aprendizado são fundamentalmente necessários.

Entendemos que na perspectiva da inclusão escolar, as identidades não são permanentes, elas estão inacabadas, em processo de formação, nada é homogêneo, tudo está sempre em um grande processo de transição.

A educação inclusiva vem com questionamento das identidades tidas como normais e procura entender as diferenças, é uma educação como o nome já diz que garante o direito a diferença de cada aluno.

\begin{abstract}
A diferença (vem) do múltiplo e não do diverso. Tal como ocorre na aritmética, o múltiplo é sempre um processo, uma operação, uma ação. A diversidade é estática, é um estado, é estéril. A multiplicação é ativa, é fluxo, é produtiva. A multiplicidade é uma máquina de produzir diferenças - diferenças que são irredutíveis à identidade. A diversidade limita-se ao existente. A multiplicidade estende $e$ multiplica, prolifera, dissemina. A diversidade é um dado - da natureza ou da cultura. A multiplicidade é um movimento. A diversidade reafirma o idêntico não havendo, nestes ambientes uma norma....o. A multiplicidade estimula a diferença que se recusa a e fundir com o idêntico (SILVA, 2000, p.100-101)
\end{abstract}

A diversidade na escola cria grupos idênticos, formados por alunos que possuem uma mesma característica, podendo assim, promover o agrupamento ou a separação dos mesmos. 
A educação inclusiva concebe a escola como um espaço de todos, onde os alunos constroem seus conhecimentos segundo suas capacidades, expressões suas ideias livremente, participam das atividades propostas pela escola, todos se igualam por suas diferenças e desenvolvem como cidadãos, cada uma em sua particularidade.

Desta forma, entendemos que o estudo da educação inclusiva no Brasil é relevante para educadores, pesquisadores e sociedade em geral, no sentido de ampliar sua visão a respeito do tema, dos conceitos e de um amplo entendimento da questão porque esses indivíduos possuem o mesmo direito a educação do que qualquer um, entender a longa caminhada na inclusão no sistema escolar para buscar os melhores métodos para auxiliar e adaptar para aqueles que precisam, buscar novos conceitos de ensino aprendizagem para ser desenvolvido o potencial desses jovens.

Este é o propósito deste trabalho, contribuir de forma sucinta com as discussões em torno da Educação Especial, tendo como "pano de fundo", a História da Educação no Brasil em suas diferentes análises.

Estudarmos a História da Educação Especial no Brasil levando em conta transformações ao longo da Historia educacional, sua inserção no ensino regular, os marcos e documentos legais e principalmente as novas concepções de educação inclusiva.

Para este estudo partimos de um referencial de pesquisa qualitativa, levando em conta a realização de análise de documentos e de conteúdos. Os documentos a serem analisados constituem-se de bibliografia, teses, dissertações, pesquisas, contidas em bibliotecas, bancos de dados (Scielo, Capes e Google Acadêmico) e sites cujo conteúdo relaciona-se ao tema em estudo.

Nosso estudo também constituirá em uma análise descritiva histórica, cuja referência teórica alicerça-se nos estudos teóricos críticos da História da Educação no Brasil, a exemplo das obras de Demerval Saviani.

\section{Corpus Documental:}

BRASIL. Ministério da Educação. Portal de ajudas técnicas para a educação: equipamento e material pedagógico para a educação, capacitação e recreação para a pessoa com deficiência física - recursos para a comunicação alternativa. Brasília: MEC/SEESP,2006. 
BRASIL. Ministério da Educação. Diretrizes nacionais para a educação especial na educação básica / Secretaria de Educação Especial - MEC; SEESP, 2001

BRASIL. Ministério da Educação. Secretária de Educação Especial. Portal de ajudas técnicas para a educação: equipamento e material pedagógico para a educação, capacitação e recreação para a pessoa com deficiência física recursos pedagógicos adaptados. Brasília: MEC/SEESP, 2006.

BRASIL. Ministério Público Federal. Procuradoria Federal dos Direitos do Cidadão. $\mathrm{O}$ acesso de pessoas com deficiência às classes e escolas comuns da rede regular de ensino. Brasília: MPF, 2003.

BRASIL. Ministério da Educação. Secretária de Educação Especial. Atendimento Educacional Especializado - Formação Continuada a Distancia de Professores para o Atendimento Educacional Especializado - Aspectos Legais e Orientação Pedagógicas. Brasília: SEESP/MEC,2007.

BRASIL. Ministério da Educação. Secretária de Educação Especial. Educação Inclusiva - 4 volumes. Brasília: SEESP/MEC, 2004

FÁVERO, E.A.G., PANTOJA, L.de M.; MANTOAN, M.T.E. O acesso de alunos com deficiência as escolas e classes comuns da rede regular. Ed. Ver. E.atual,. Brasília: Procuradora Federal dos Direitos do Cidadão, 2004.

MACHADO,R. Educação especial na escola inclusiva: políticas, paradigmas e praticas. São Paulo: Cortez, 2009.

\section{REFERÊNCIAS}

BARROS, Roque Spencer M. de. A ilustração brasileira e a ideia de universidade. São Paulo: Faculdade de Filosofia, Ciências e Letras da USP, 1959.

BERTOTTI, Rudimar Gomes, RIETOW, Gisele. UMA BREVE HISTÓRIA DA FORMAÇÃO DOCENTE NO BRASIL: DA CRIAÇÃO DAS ESCOLAS NORMAIS AS TRANSFORMAÇÕES DA DITADURA CIVIL-MILITAR. Curitiba: EDUCERE, 2013

CUNHA, Luiz Antonio; GÓES, Moacyr de. 0 golpe na educação. Rio de Janeiro: J. Zahar,1985.

FREIRE, Paulo. Educação e Atualidade Brasileira, 1956. ROMÃO, Eustáquio (Org.).São Paulo: Cortez: Instituto Paulo Freire, 2012.

LIBANEO, Jose Carlos. Adeus Professor, Adeus Professora? Novas Exigências Educacionais e Profissão Docente. São Paulo: Cortez, 2010.

MANTOAN, M.T.E. A integração de pessoas com deficiência: contribuições para uma reflexão, sobre o tema. Memnom, 1997. 
MANTOAN, M.T.E(Org.) O desafio das diferenças nas escolas. Petropolis: Editora Vozes, 2008.

MANTOAN, M.T.E. O direito de ser, sendo diferente, na escola. In: Revista de Estudos Jurídicos. Brasília: n.26,2004.

MANTOAN,M.T.E. Inclusão escolar: o que é? Por quê? Como fazer? São Paulo: Editora Moderna, 2003.

MOTTA, Rodrigo Patto Sá. As universidades e o regime militar. São Paulo: Zahar, 2014.

REIMÃO, Sandra. Repressão e resistência: censura a livros na Ditadura Militar. São Paulo: Edusp, Fapesp, 2011. 179 p.

ROMANELLI, Otaíza de Oliveira. História da educação no Brasil. 13. ed. Petrópolis: Vozes, 1984.

SAVIANI, Dermeval. Formação de professores: aspectos históricos e teóricos do problema no contexto brasileiro* , Revista Brasileira de Educação v. 14 n. 40 jan./abr. 2009

SAVIANI, Dermeval. História das Ideias Pedagógicas. Campinas: Autores Associados, 2007.

TANURI, Leonor Maria. História da Formação de Professores. Revista Brasileira de Educação. Campinas: n.14, p. 61-88, mai./jun./jul./ago., 2000. 


\title{
IDOSO E PALHAÇO UMA RELAÇÃO DE EMPODERAMENTO
}

\author{
SILVA, Juliano Aparecido da \\ Pós-Graduado em Tecnologias na Aprendizagem - Senac São Paulo \\ juliano.asilva@sp.senac.br
}

\section{INTRODUÇÃO}

Empoderar - se! Este é um desafio que a constituição brasileira de 1988 lançou a toda a população brasileira. Com a sua regulamentação através de códigos e estatutos, outra incitação: Transformar o território.

Em uma sociedade voltada para novas tecnologias. Como superar essas barreiras junto à pessoa idosa?

O presente texto busca apresentar a união da figura do palhaço como um guia para pessoa idosa, não como um condutor que sempre o levará e sim como aquele que indica o caminho:

\footnotetext{
Nem muito alto, nem muito largo, nem imperador, nem rei. Você é só um marco de estrada, que se ergue junto ao caminho. As pessoas passam, você indica a direção certa, e impede que elas se percam (Ho Chi Minh 1890-1969).

"É importante, pois salientar que o envelhecimento, por ser um evento biológico e cultural, pode ainda ser observado do ponto de vista histórico e socialmente contextualizado, onde tratamento que é dispensado aos idosos dependerá dos valores e da cultura de cada sociedade sob as quais ela construirá sua visão dessa última etapa da vida" (SANTOS, JUNIOR, 2014, p.39).
}

Além da valorização de se seus direitos e para regulamentar estas conquistas, surgem códigos e estatutos e com a população idosa não foi diferente nasceu em 01 de outubro de 2013 o Estatuto do Idoso. O evidenciado documento em seu primeiro artigo, define idoso como a pessoa com idade igual ou superior a 60 anos. Em 2017 a população idosa do Brasil era de 30,2 milhões (Agência Globo, 2018), grupo que vem aumentado a cada ano. Com o crescimento da população de idosos, surgem as necessidades de políticas públicas voltadas à pessoa idosa.

Desse modo, principalmente em razão do aumento dessa faixa etária, a atenção ao idoso tem estimulado a realização de estudos e publicações gerontológicas, que solicitam um enfoque mais amplo e interdisciplinar dos profissionais envolvidos na busca de uma melhor qualidade de vida para os que ingressaram na velhice (CARVALHO, 2018, p.13). 
Neste trabalho, jogos e brincadeiras, no geral, são considerados atividades dinamizadoras que podem estimular as funções cognitivas e a criatividade, ampliar o imaginário e o repertorio gestual, bem como liberar emoções, reforçar o autoconceito, a autoestima e a autoimagem, e facilitar a interação entre os participantes. Entre essas possibilidades de estimulação a ludicidade e uma das mais significativas, porque está relacionada com o prazer de fazer. (CARVALHO, 2018, p.14).

Neste contexto, nascem vários profissionais para vivenciar com a população sexgenária uma qualidade de vida, estimulados pelo terceiro artigo do Estatuto do Idoso. O estatuto garante o direito ao lazer, e neste contexto surge uma relação com aproximadamente quatro mil anos de história, 0 palhaço acumula várias vivências neste mundo, seu legado começa como conselheiro nas cortes orientais, tendo poder de fazer com que o imperador mudasse de ideia.

Passou pela Grécia, Roma, Alemanha, Malásia, Itália, deixando seu legado e sua alegria. Ao longo desta caminhada adaptou-se se reinventou, teve vários nomes e estilos, "Cicirro, Estúpido, gleemen, jongleurs, bufão, Arlequim,clown etc..."

Hoje está presente na televisão, teatro, circo, hospitais, escolas e ruas. Sempre com seu jeitão peculiar e com tradicional nariz vermelho.

Segundo Puccetti:

O palhaço não tem uma forma fixa e definida, ele é um conjunto de impulsos vivos e pulsantes, prontos a se transformarem em ação no espaço e no tempo. Esses impulsos se concretizam ou se manifestam sempre obedecendo três parâmetros: a lógica do palhaço, entendida como sua maneira de "pensar" (o agir e o reagir com seu corpo); a interação com cada indivíduo do público e o jogo estabelecido entre palhaço e público.(Puccetti, 2008, p.122-123)

Está versatilidade do palhaço faz com que ele tenha facilidade de interagir com diversos públicos criando assim um laço com todo aquele que com ele se interage com um simples sorriso ou uma grande gargalhada.

Da versatilidade do palhaço surge a palhaçoterapia, ciência ou arte com muitas definições sendo uma das mais simples delas, publicada na revista CONACIS em 2104:

Palhaçoterapia, ou arte com palhaços, envolve ações lúdicas permeadas de risos, brincadeiras, faz-de-conta e muita alegria visando à socialização e o enfrentamento da ansiedade, traumas e do medo. (JUNIOR, S. V. D. S; CARVALHO, J. M. D; II, J. C. C. D. O. 2014)

$\mathrm{Na}$ execução da palhaçoterapia o histrião estabelece um diálogo com o seu interlocutor, esse por sua vez confia nele e aos poucos se entrega 
agraciado por seu jeito simples e às vezes bobo de interação. A ação que desencadeia toda esta entrega é o riso, ato na maioria das vezes involuntário no rosto de todo aquele que apenas olha para o palhaço. Este diálogo ganha força quando os dois estão conectados palhaço e interlocutor, neste momento a alegria toma conta de todo o território, trazendo para colocutor e para histrião a alegria.

Alegria: Desta, segundo o filósofo Espinosa, nascem: o amor e a esperança. Sendo esta última considerada por ele como a potência do agir. Potência esta que impulsiona o existir da palhaçoterapia.

Metodologia

A atividade aconteceu em municípios de pequeno médio porte do interior paulista, todas durante a denominada semana do idoso, realizada nos primeiros dias do mês de outubro.

Ocorridas junto aos grupos de idosos dos serviços de convivência e fortalecimento de vínculos, vinculados ao Centros de Referência Sociais dos Municípios.

Os grupos contavam com média de trinta idosos cada, em primeiro momento buscou-se a criação de vínculos, o diálogo, com um apito o palhaço Antúrio interagiu com os presentes brincando e apresentando um cartaz com os dizeres: "A LATA QUE MATA". Após muitos divertimentos tira de uma sacola de pano, tradicional "capanga", uma lata de aço com a epígrafe: "Veneno" . Momento de muita risada, pois a lata mata! Vínculo criado! Surge ai a potência do agir a : Alegria.

No segundo momento o histrião Antúrio passa a convidar os idosos para atividades de recreação e alguns jogos de cooperação como: Shishima Humano, Amarelinha Africana, Corrida da Memória entre outras, todas visando lazer, cultura e liberdade.

\begin{abstract}
Para os idosos, jogar e brincar trazem o gosto e o gozo de infância; a lembrança dos companheiros e amigos, a espontaneidade e a alegria de que desfrutaram há 50, 60 anos. Por outro lado, para os profissionais e voluntários que trabalham com grupos de idosos, essas atividades podem facilitar o direcionamento do encontros, a sensibilização e a reflexão sobre determinados temas, além de auxiliar a regulação corporal, aumentando ou diminuindo o nível de ativação física de seus integrantes. (Carvalho, 2018)
\end{abstract}

\title{
2. RELATO DE EXPERIÊNCIA
}

O palhaço Antúrio é um personagem de um profissional que cresceu com o ideal de fazer as pessoas se alegrarem, sempre brincalhão, era 
convidado pelos conhecidos para animar festas de aniversário e teatro escolares, assim nasce o palhaço Antúrio que tem a seguinte história:

Antúrio o Inocente.

Em uma terra distante, chamada Húmus, na família Anthurium Andraeanum, nascia o pequeno Antúrio Yellow Innocens. Antúrio era filho do senhor Simplício e de Dona Inocência.

Cresceu junto de um povo feliz e sem maldade, que buscava sempre fazer os outros felizes, tinha muitos parentes, entre eles destacavam os primos: Antúrio Black Queen, Antúrio Green King, Antúrio Pink Queen, Antúrio Red Victory, Antúrio Red Winner, Antúrio Snow King, Antúrio Tangerine e Antúrio Thunder Bird.

Com a inocência herdade de sua mãe e a simplicidade de seu pai, Antúrio, sempre mostrava o caminho a ser trilhado por todos aqueles que dele se aproximava. Tinha sempre em seu coração a frase de Ho Chi Minh que diz: "Nem muito alto, nem muito largo, nem imperador, nem rei. Você é só um marco de estrada, que se ergue junto ao caminho. As pessoas passam, você indica a direção certa, e impede que elas se percam. Você informa a distância que se precisa ainda a percorrer. Sua tarefa não é pequena e toda gente lembrará de você. " Com esta frase na mente, Antúrio decidiu sair pelo mundo indicando o caminho a todos aqueles que querem realizar seus sonhos.

Antúrio integra os HumanOterapeutas, um grupo de profissionais com ideais de humanização na gestão de pessoas, que utilizam da linguagem e imagem do palhaço para disseminar este conceito.

Fazem parte dos HumanOterapeutas os palhaços Felizbino Tchelon, Maricota e Pardal.

$\mathrm{Na}$ intervenção junto aos grupos de idosos pode se notar que todos ao perceberem a presença do palhaço retomam suas alegrias e esperanças, logo estão interagindo, contando suas histórias, dando conselhos e sugerindo inclusive brincadeiras e atividades, sem contar aqueles que pedem um nariz para assumir sua personagem como de Histrião.

O imaginário é capaz de revelar segredos, reabrir desejos e clarear a própria realidade humana. Proporcionar o riso para as pessoas em situação de risco, vulneráveis, com dificuldades, significa levá-las a realizar associações imaginativas e inteligentes. Como já discutido na literatura, para provocar o riso em situações de drama humano, temos que nos distanciar dele e realizar associação de ideias. Portanto, exige uma anestesia momentânea do coração, dirigir-se à inteligência. (Bergson, 2001)

A arte é um instrumento de suma importância na vida do indivíduo, pois colabora para o seu desenvolvimento expressivo e com a criatividade, tornando o sujeito com um olhar sensível frente ao mundo ao seu redor (Coleto,2010).

Nesta intervenção todos após viverem a lembrança de momentos

felizes e também superando alguns de seus momentos de chateações, se sentem empoderados para a vida cotidiana da pessoa idosa.

\section{LAZER, CULTURA E LIBERDADE}


O artigo terceiro do estatuto do idoso elenca uma série de garantias determinadas a família, comunidade, sociedade e poder público, dentre elas temos: O Lazer, a Cultura e a Liberdade, sendo estas que mais se aproxima a vida de um palhaço, Cavallari e Zacharias definem:

Lazer é o estado de espírito em que o ser humano se coloca, instintivamente (não deliberadamente), dentro do seu tempo livre em busca do lúdico (diversão, alegria e entretenimento) (Cavallari e Zacharias, 2018, p.15)

Alegria, diversão e entretenimento são praticamente a vida de um palhaço, sendo ele então aquele que proporciona o lazer.

Cultura significa todo aquele complexo que inclui o conhecimento, a arte, as crenças, a lei, a moral, os costumes e todos os hábitos e aptidões adquiridos pelo ser humano não somente em família, como também por fazer parte de uma sociedade da qual é membro. (Significados, 2019)

Em seus quatro mil anos de vivência o palhaço se adaptou a várias culturas e regiões tendo ele facilidade para se conectar a população idosa.

Vê se assim, curiosamente, que essa "realidade "de 'Amor", além de nos conduzir a uma perspectiva de "possibilidades de conexões", também deixa patente o mistério da "liberdade" presente em cada ser humano! (Santo, 2007)

Liberdade significa o direito de agir segundo o seu livre arbítrio, de acordo com a própria vontade, desde que não prejudique outra pessoa, é a sensação de estar livre e não depender de ninguém. (Significados, 2019)

Nada prende o palhaço ele é livre, vive no ócio no nada fazer, porém "o nada fazer de forma lúdica, positiva e opcional. Pode ser uma opção de lazer." Cavallari e Zacharias, 2018

Com sua liberdade, vivendo do lúdico e do lazer o palhaço vai contaminando as pessoas com sua alegria criando ainda uma cultura diferente, de conexões, carinho, amor e valorização.

Como cultura passa de geração em geração pode ser possível de um dia todos estarem conectados e valorizando muito mais a pessoa idosa.

\section{CONSIDERAÇÕES FINAIS}


As instituições voltadas para pessoa idosa recrutam profissionais de diversas áreas para realizar suas atividades e atingir seus objetivos, são estes idôneos e competentes.

Entre eles está o palhaço, que em suas intervenções consegue interagir com facilidade com a pessoa idoso, pois:

Combina o repertório físico e vocal (seu comportamento, suas ações e reações frente a estímulos), o repertório de idéias (a lógica pessoal de cada indivíduo que transparece no palhaço), o repertório de gags (pequenas situações cômicas em seqüência ou isoladas) e, através do jogo vivo e real da cena, interagir com cada indivíduo do público é parte fundamental da técnica do palhaço. (Puccetti, 2008, p.122-123)

Consegue fazer com que a pessoa se abra e conte um pouco de si de uma forma natural e tranquila, boa parte do idoso gosta de relembrar situações passadas em sua vida, o palhaço traz a tona esta memória. Um participante conta sua história de um lado, outro lá no canto, de uma hora para outra aparecem aqueles que moraram na mesma cidade, mesmo bairro, trabalharam na mesma empresa e assim uma aproximação.

Se o palhaço possui essa "inteireza" e prazer de existir, ele vai emocionar e surpreender a platéia, provocá-la e conduzi-la do sorriso à gargalhada. E cada pessoa do público sairá com a sensação de ter feito parte do espetáculo..(Puccetti, 2008, p.122-123)

O sentimento de pertença é importante para pessoa idosa, na maioria das vezes ela interpreta que o tempo dela já foi o mundo de hoje não é para ela, interagindo de uma forma lúdica com o palhaço devagar ela entende que pertence não só ao tempo atual como ao grupo da qual está vinculada, como nos mostra a raposa ao pequeno príncipe.

\footnotetext{
Minha vida é monótona. Eu caço as galinhas e os homens me caçam. Todas as galinhas se parecem e todos os homens se parecem também. E por isso eu me aborreço um pouco. Mas se tu me cativas, minha vida será como que cheia de sol. Conhecerei um barulho de passos que será diferente dos outros. Os outros passos me fazem entrar debaixo da terra.O teu me chamará para fora da toca, como se fosse música. ( Saint-Exupery, 2009, p.49)

"Que quer dizer "Cativar"?

- É uma coisa muito esquecida, disse a raposa. Significa "criar laços"." ( Saint-Exupery, 2009, p.49)
}

Em seu diálogo com a raposa, no livro: O pequeno príncipe, o infante, talvez, por viver sozinho em seu planeta não conhecia o que era criar laços, vincular-se a alguém.

Situação comum com uma parcela dos idosos pois por viverem em épocas diferentes e com situações diferentes se distanciam dos demais, por não saírem nas ruas temendo por sua segurança, perdem o contato até com vizinhos, velhos conhecidos. 
Em casa boa parte sente-se sozinhos por não fazerem uso de smartphones e redes sociais, ficando isolados enquanto os demais familiares utilizam das novas Tecnologias de Informação e Comunicação.

Impulsionados pelo Estatuto do idoso despontam os Centros de Integração da Terceira Idade (CITIs), Centros de Convivência de Idosos (CCI), Clubes de Velha Guarda, Associações da Terceira Idade, Pastoral da Pessoa Idosa,Centro dia do Idoso entre outras instituições. A maioria destas entidades contam com o Serviço de Convivência e Fortalecimento de Vínculos.

Criando laços buscam: Oferecer lazer, cultura, liberdade, superar os mitos a respeito da velhice, superar limites e sonhar, inclusão e valorização da pessoa idosa e prevenir o isolamento social do idoso.

"Mas, se tu me cativas, nós teremos necessidade um do outro."( Saint-Exupery, 2009, p.49)

Após criar vínculo com a raposa e ela com ele ambos tinham a necessidade de conviver juntos ou ao menos se encontrar vez em quando, assim o criando e fortalecendo o vínculo com a e entre as pessoas idosas temos a cultura de valorização e respeito com os mesmos.

A constituição cidadã de 1988, deu a todos, voz, vez e lugar, infelizmente o país vem de uma cultura secular de diferenças e talvez de pouca informação, neste contexto busca-se integrar todos os cidadãos entregando a eles seus direitos e espaços.

É um processo longo haja vista que a primeira "barreira" a ser vencida é a cultural, estamos a 31 anos da promulgação da carta magna e muitos ainda não aceitam ou desconhecem relevantes mudanças.

Neste cenário é interessante uma atualização passo à passo. Sendo o primeiro passo a conquista, sobretudo com a pessoa idosa, sempre desconfiada. Em um panorama assim a figura do palhaço tem muita facilidade de adentrar, pouco a pouco conquista pessoas, das mais diferentes faixas etárias, trazendo todos para perto e assim estabelecer confiança e começar os demais passos desta transformação social.

Estimulando ainda uma reflexão com a relação a cultura que naturalmente e por vezes desapercebida de que o idoso já cumpriu o seu papel e não tem mais nada a contribuir com a sociedade pois já passou por seu período laboral e não tem condições de realizar tarefa alguma.

Juntos, palhaço e pessoa idosa, são contadores de história: "Assim quanto mais idosa a pessoa, maior o número de informações de que dispunha, graças à sucessão de experiências de vida que tivera." (DANTAS,2019,p18) E o palhaço tem quatro mil anos de história!

Assim como o arauto, é aquele que leva a mensagem. 
E lembremos que 0 arauto era um personagem essencial para a sociedade (DANTAS, 2019, p.61)

Contador de histórias, arautos. Sim! Ambos: Palhaço e idoso estão a disseminar a cultura da valorização da pessoa idosa.

\section{REFERÊNCIAS}

AGÊNCIA GLOBO. Brasil já tem 30 milhões de idosos, e número de crianças diminui. Disponível em: https://oglobo.globo.com/economia/brasil-jatem-30-milhoes-de-idosos-numero-de-criancas-diminui-22629229. Acesso em: 10 jul. 2019.

BERGSON H. O riso: ensaio sobre a significação da comicidade. São Paulo: Martins Fontes; 2001.

CARVALHO, Noeme Cristina; Dinâmica para Idosos: $7^{a}$. ed. Rio de Janeiro: Vozes, 2014

CAVALLARI, Vinicius Ricardo; ZACHARIAS, Vany; Trabalhando com recreação: 14. ed. São Paulo: Icone, 2018. p. 14-15.

COLETO, Daniela Cristina. A IMPORTÂNCIA DA ARTE PARA A FORMAČ̃̃O DA CRIANÇA: .. REVISTA CONTEÚDO: ., Capivari, v. 1, n. 3, p. 137-146, jul./2010.

http://www.conteudo.org.br/index.php/conteudo/article/viewFile/35/34. Acesso em: 4 set. 2019.

DANTAS, Goimar; A arte de criar leitores: Reflexões e dicas para uma mediação eficaz. 1‥ ed. São Paulo: SENAC, 2019

ESPINOSA B. Ética III: Da origem e da natureza das afecções. São Paulo: Abril Cultural; 1972.

JUNIOR, S. V. D. S; CARVALHO, J. M. D; II, J. C. C. D. O. PALHAÇOTERAPIA E POSTURA ÉTICA NA ASSISTÊNCIA ÀS CRIANCAS VERTICALMENTE EXPOSTAS AO VÍRUS HIV. Anais CONACIS, CAJAZEIRA - PB, v. 1,abr./2014. Disponível em: https://www.editorarealize.com.br/revistas/conacis/trabalhos/Modalidade_3data hora_12_03_2014_21_12_37_idinscrito_90_ec68ddd874a6650b61e07129af4dd aa2e.pdf. Acesso em: $\overline{2}$ set. 2019.

MUNDO CLOWN. Um pouco da história. Disponível em: https://web.archive.org/web/20140103210758/http://www.mundoclown.com.br/u mpoucodahistoria. Acesso em: 11 jul. 2019.

PALHAÇO ANTÚRIO. História do Palhaço Antúrio. Disponível em: www.palhacoantúrio.com.br. Acesso em: 12 jul. 2019. 
PRESIDÊNCIA DA REPÚBLICA. Estatuto do Idoso. Disponível em: http://www.planalto.gov.br/ccivil_03/leis/2003/110.741.htm. Acesso em: 10 jul. 2019.

PUCCETTI, Ricardo. No caminho do palhaço: subtítulo do artigo. ILINX: Revista do LUME, Campinas, v. 1, n. 1, p. 121-127, jul/2008. Disponível em: https://www.cocen.unicamp.br/revistadigital/index.php/lume/article/view/231/222 . Acesso em: 11 jul. 2019.

SAINT-EXUPERY, Antoine De; O pequeno príncipe: 48. ed. Rio de Janeiro: Agir, 2009. p. 65-68.

SANTOS, F. D. S; JÚNIOR, Joel Lima. O Idoso e o Processo de Envelhecimento: Um estudo sobre a qualidade de vida na terceira Idade. ID on line: Revista de Psicologia, v. 8, n. 24, p. 34-55, nov./2014.ISSN 1981-1189. Recebido: 07/11/2014; Aceito: 21/11/2014

Disponível em: https://idonline.emnuvens.com.br/id/article/view/300/409. Acesso em: 10 jul. 2019.

SANTOS, R. F. D; PACHECO, Reinaldo; Lazeres: Para fazer melhor é preciso compreender. 1‥ ed. São Paulo: SENAC, 2018

SANTO, R. C. D. E; Autoconhecimento na formação do educador: 1. ed. São Paulo: Ágora, 2007.

SIGNIFICADOS. Cultura. Disponível em: https://www.significados.com.br/cultura/. Acesso em: 11 jul. 2019. 


\title{
INTERPRETAÇÕES ACERCA DA ESCRAVIDÃO NO BRASIL E SEUS DESDOBRAMENTOS CONTEMPORÂNEOS NA EDUCAÇÃO
}

\author{
ARAÚJO, Guilherme Lima de \\ Pós-Graduando em História, Cultura e sociedade - CUBM \\ guilherme.wylde@hotmail.com
}

\section{INTRODUÇÃO}

Em tempos de "Escola sem Partido", retrocessos e cortes nas áreas sociais, educacionais e das ciências humanas em especial, é de condição sine qua non uma reflexão acerca dos objetivos e finalidades do Ensino de História.

É importante destacar que a História, como indica Jacques Le Goff (1990) "[...] é o produto mais perigoso que a química do intelecto elaborou... A História justifica o que se quiser." (VALÉRY apud LE GOFF, 1990, p. 32), tornando-a campo fértil para todos os tipos de embates. Não obstante, no clássico distópico "1984", o autor George Orwell defende que "Quem controla o passado, controla o futuro; quem controla o presente, controla 0 passado" (ORWELL, 2009, p. 40) a fim de justificar a importância e a força de coesão que as narrativas sobre o passado exercem sobre o presente.

A historiografia acerca da escravidão é mais um campo onde os embates de narrativa se desenrolam, visto que determinados grupos com determinados interesses têm preferências por certas versões do passado. Contudo, compreender essas discussões nos ajuda a conhecer melhor nossa própria História e nos prepara para evitar reducionismos simples e maniqueísmos baratos. Por sua vez, a fuga de armadilhas que podem minar 0 caminho para o entendimento da historiografia passa pela reflexão da máxima dos nossos antepassados romanos, "Cui bono?", ou seja, quem se beneficia com tal construção do passado?

No campo da Historiografia, como indica Luís Cláudio Palermo (2017), as narrativas do passado também podem ser entendidas como "tradições eletivas";

[...] cumpre ressaltar que as tradições [...] devem ser vistas menos pelo sentido corriqueiro, quer dizer, de uma tradição que nos deixa um legado e mais pelo sentido invertido, ou seja, de uma tradição que é construída pelos atores sociais do presente.

Ao proporcionar a importância do presente como primordial na construção das tradições, é importante destacar [...] por conseguinte, a perspectiva de futuro como algo crucial que reveste os embates por construção de tradições que são feitas no presente. Em outros termos, o conceito de tradições eletivas contribui para nos mostrar 
quanto uma tradição não é meramente recebida, mas, sobretudo, construída a partir de uma dimensão contextual do presente e, inextricavelmente, das expectativas de futuro. (PALERMO, 2017, p. 326).

Assim sendo, esse trabalho tem como principal objetivo compreender as principais discussões historiográficas em torno da temática escravidão e suas representações e desdobramentos, com a finalidade de colaborar e aprimorar as discussões existentes no campo do Ensino de História atrelado as questões étnico raciais e cultura afro-brasileira. Dessa maneira,

\begin{abstract}
Metodologicamente, esse estudo parte eminentemente da noção de que, na historiografia, as interpretações do passado estão em disputa [...] permeado por contendas políticas, ideológicas e epistemológicas que reverberam no seio das representações sobre o passado ou do uso que se faz do passado. (PALERMO, 2017, p. 325-326).
\end{abstract}

\title{
2. CONTRIBUIÇÕES DE GILBERTO FREYRE PARA A HISTORIOGRAFIA ESCRAVISTA
}

No que tange a primeira grande das 3 tendências historiográficas ligadas a escravidão no Brasil, o destaque é para Gilberto Freyre e sua principal obra "Casa Grande \& Senzala", da década de 1930.

Além do texto colossal e da inovação metodológica - que graças a influência de Franz Boas trouxe para a historiografia brasileira uma visão antropológica ligada ao desenvolvimento cultural - o maior mérito de sua obra é "romper com as ideias pseudocientíficas sobre a inferioridade da cultura africana, destacando de modo incisivo as raízes dessa cultura e, por conseguinte, ressaltando sua importância na formação do Brasil." (PALERMO, 2017, p. 327).

Freyre advogou a tese de que a miscigenação, em vez de ser um mal para a sociedade brasileira foi importante fator na formação do Brasil. [...] o sociólogo pernambucano em destaque valorizou a cultura africana, assim como o papel do negro, na sociedade brasileira e na formação do Brasil. (PALERMO, 2017, p. 330).

As consequências dessas ideias é elevar a contribuição da cultura afro na construção da cultura brasileira, isolando em um espectro oposto da historiografia as tendências racistas e supremacistas da cultura branca vigentes até então.

O principal objeto de estudo de Freyre são as relações entre senhor e escravo, relações essas que acontecem tanto no âmbito privado do 
senhor - na casa grande e no intercâmbio sexual - e no âmbito público do escravo - na senzala e na vida cotidiana, de tal modo que autor pode vislumbrar as convivências íntimas, cotidianas e privadas.

Contudo, a crítica ao trabalho de Freyre se baseia na intenção do autor em evitar as tensões entre esses grupos, equilibrando os antagonismos evidentes na sociedade.

2.1 Contribuições da Escola Paulista de Sociologia para a historiografia escravista

A segunda tendência, a Escola Paulista de Sociologia, das décadas de 1950, 60 e 70, tem como expoentes Fernando Henrique Cardoso, Octávio lanni, Florestan Fernandes... entre outros, e busca construir uma nova "tradição eletiva", ou seja, compreender demandas da sociedade atual através de uma interpretação específica do passado.

Influenciados pela obra de cunho marxista de Caio Prado Júnior, os trabalhos da Escola Paulista em sua grande medida vão tentar compreender o papel da escravidão no Brasil como uma página no grande livro do Capitalismo mundial.

[...] a influência da obra de Prado Júnior levou os pesquisadores da Escola Paulista a pensarem a escravidão como estrutura fundamental no processo de acumulação do capital, produzindo uma visão ancorada na ideia de sistema escravista diretamente ligado ao capitalismo comercial global, que objetivava, basilar e pragmaticamente, o lucro, sendo essencial, para tanto, o controle, a repressão e a coerção da mão de obra. (PALERMO, 2017, p. 332).

Um dos muitos estudos que fundamentam tal tese parte da análise da sociedade riograndense feita por de Fernando Henrique Cardoso, na qual o autor argumenta que a necessidade de aumentar a produtividade agrícola no século XIX a fim de aumentar os lucros, está relacionada com o aumento da população escrava para trabalharem como mão de obra nas lavouras.

Diante desses argumentos, os desdobramentos teóricos metodológicos nos permitem destacar a relação entre base e estrutura, como defendem os marxistas ortodoxos. "[...] as relações materiais que os homens estabelecem, o modo como produzem seus meios de vida, formam a base de todas as suas relações" (QUINTANEIRO; BARBOSA; OLIVEIRA, apud PALERMO, 2017, p. 334). necessário;

Não obstante, sobre a relação entre base e estrutura, é 
Conhecer a infraestrutura de uma sociedade, sobretudo sua dimensão econômico-social, significa, [...] revelar suas partes e suas inter-relações, que são responsáveis pela construção da superestrutura. Por isso, o autor afirma que o modo de produção é crucial para a elaboração do processo da vida social, política e intelectual. (PALERMO, 2017 p. 334).

Dessa maneira, podemos destacar que o antagonismo - agora evidente - é inconciliável, já que os interesses dos senhores e dos escravizados são opostos. Nessa perspectiva, os escravos, que são mão de obra e que tem sua existência e finalidade última justificada para aumentar a lucratividade do senhor, são vistos como objetos.

O mérito da visão desses pesquisadores foi compreender os desdobramentos do capitalismo mundial e sua influência no Brasil, além do fato de levarem em consideração a luta social do negro, que graças ao processo de escravização, ficou à margem da sociedade.

Por outro lado, o maior ponto negativo se baseia na crítica a excessiva generalização dos processos de relações inter-raciais, que é uma consequência da interpretação estruturalista marxista, que da primazia da classe (coletivo) sobre os indivíduos.

2.2 A escravidão como negociação para a sobrevivência e suas contribuições para a historiografia

A terceira e última tendência da narrativa escravista no Brasil surge logo após os estudos da Escola Paulista, na década de 1980, onde vários pesquisadores tencionam a interpretar a escravidão não apenas como fenômeno de coerção, mas também de negociação, visando a adaptação para a sobrevivência;

Baseados numa visão integracionista da sociedade escravista, alguns estudiosos têm sugerido que os grupos [de] escravos na busca de forjar espaços de autonomia econômica, social e cultura, interagiram com o regime de trabalho, moldando [...] o sistema escravista que procurava reduzi-los a meros instrumentos de produção das riquezas coloniais. (MACHADO apud PALERMO, 2017, p. 338).

Com base nessa narrativa, o estudo de famílias, indivíduos e histórias individuais começou a ganhar força, uma vez que para tais pesquisadores, os negros escravizados foram agentes ativos de sua própria História. 
Contudo, é necessário atenção para não cometer na contramão os erros da Escola Paulista, permitindo com que os acontecimentos individuais isolados da microestrutura se sobreponham a macroestrutura, podendo permitir um abrandamento da relação violenta e repressiva que foi a escravidão brasileira.

Desse modo, as críticas dos estudiosos da Escola Paulista a essa terceira tendência serão muito pontuais e versarão sobre a falta de conhecimento do processo de escravidão como um todo, já que esses pesquisadores não dão conta de atrelar os fenômenos microestruturais com 0 desenvolvimento do capitalismo global, como tentavam os próprios marxistas. Entretanto, é importante destacar que a temática seguida por essa terceira tendência historiográfica permitiu muitos avanços no conhecimento da nossa própria História e da luta pela inserção do negro como agente ativo de sua própria História, criando uma nova "tradição eletiva".

Em outros termos, a partir da década de 1980, pesquisadores passaram a interpretar o nosso passado escravista com base em outro aparato conceitual e teórico, pois estavam influenciados por mudanças contextuais (no campo político brasileiro e no campo da historiografia ocidental) e expectativas de futuro que também estavam em transformação. (PALERMO, 2017, p.339).

2.3 As tendências historiográficas escravistas e seus desdobramentos na educação

O desdobramento lógico dessas reflexões nos guia para duas questões importantes. Será que os professores têm formação adequada? Ou ainda, será que os materiais didáticos estão de acordo com tais demandas, legais e sociais?

Se a resposta para alguma dessas questões for não, então todo o propósito e reivindicações acerca de esclarecer e compreender melhor o processo escravista no Brasil e seus reflexos na sociedade contemporânea a fim de propor condições de igualdade e justiça social aos negros foi em vão, pois professores ou livros didáticos equivocados apenas reproduziriam versões inadequadas do passado e que não estariam em consonância com as visões demandadas para a construção do futuro pretendido.

Quanto a capacitação dos professores para tratar do tema, vale ressaltar que a necessidade criada pela lei fez aparecer a oferta por disciplinas no ensino superior, além de cursos de especialização. Contudo, apesar dos 16 anos passados da assinatura da lei, o estudo das relações étnico-raciais e da cultura afro-brasileira ainda é um campo de pesquisa muito fértil e que continua em crescimento, justamente devido a constante batalha de ressignificação do passado. 
Um exemplo que elucida a necessidade dos professores a buscar a constante formação continuada na área para melhor atenderem as necessidades passa por questões teóricas complexas, como por exemplo, o que é ser negro no Brasil? É uma questão atrelada apenas a cor da pele, ou a um processo histórico? E por tanto, se assim for, os traços e as heranças culturais podem superar as características fenotípicas?

Martha Abreu e Hebe Mattos (2008) indicam que;

Colocando no centro do debate conceitos de raça, identidade negra, racismo, democracia racial, cultura negra, cultura afro-brasileira, pluralidade cultural e cultura brasileira, a política educacional proposta pelas "Diretrizes" exige o aprofundamento desses conceitos e sua contextualização no processo histórico. Para além do evidente envolvimento de educadores, as "Diretrizes" convocam os profissionais de história para uma ampla reflexão sobre a história da cultura afro-brasileira, em suas dimensões de pesquisa e ensino. (ABREU; MATTOS, 2008, p. 8).

Esses fatos evidenciam a complexidade de algumas questões que os professores terão de enfrentar em sala de aula. Nesses casos em específico, não há Diretrizes ou documentos oficiais que orientem os professores, apenas estudos acadêmicos.

Por outro lado, temos os livros didáticos, que são ferramentas essenciais para 0 trabalho docente e estão presentes em praticamente todas as escolas graças ao PNLD (Programa Nacional do Livro Didático).

O PNLD basicamente universalizou o acesso aos livros didáticos, uma vez que através desse programa, o Governo Federal garante 0 financiamento e a distribuição gratuita de livros a todos os estudantes. Contudo, vale ressaltar que apenas os livros que estão de acordo com o edital são comprados e repassados, ou seja, há um processo de seleção e só são comprados os livros que atendem aos requisitos do edital.

Evidentemente graças a força da lei 10.639 , os livros didáticos são orientados a seguir certos pressupostos, como por exemplo, promover de maneira positiva a cultura afro-brasileira a fim de lutar ativamente contra estereótipos e visões equivocadas do papel do negro escravizado na sociedade, como pode ser visto a seguir neste recorte feito do edital do PNLD 2019 para os anos iniciais do Ensino Fundamental, onde os livros que desrespeitarem os seguintes itens, serão excluídos do catálogo de compra e distribuição:

Promover postura negativa em relação a imagem de afrodescendentes e dos povos do campo, desconsiderando sua 
participação e protagonismo em diferentes trabalhos, profissões e espaços de poder;

j. Promover postura negativa em relação a cultura e história afrobrasileira e dos povos indígenas brasileiros, desvalorizando seus valores, tradições, organizações, conhecimentos, formas de participação social e saberes socio científicos, desconsiderando seus direitos e sua participação em diferentes processos históricos que marcaram a construção do Brasil, desvalorizando as diferenças culturais em nossa sociedade

multicultural;

k. Abordar a temática das relações étnico-raciais, do preconceito, da discriminação racial e da violência correlata, de forma não solidária e injusta;

I. Desconsiderar a diversidade cultural, social, histórica e econômica do país nos textos, enfoques e exemplos utilizados nas obras. (BRASIL, 2017, p. 31).

Pelo menos em teoria, há nos próprios mecanismos de compra e distribuição de livros didáticos empecilhos quanto ao descumprimento da lei.

Não obstante ao clima de dúvidas e incertezas, Abreu e Mattos nos indicam que;

Recentes pesquisas sobre a organização e os significados da família escrava, sobre as lutas dos escravos e libertos pela realização de suas festas e crenças, sobre as fugas, quilombos e revoltas, ou sobre a luta dos próprios escravos e seus descendentes pela abolição já têm recebido espaço de divulgação, embora ainda pequeno, nos livros didáticos, nos cursos de atualização de professores e em revistas de grande circulação. (ABREU; MATTOS, 2008, p. 8).

Aos olhos de desavisados, muitas dessas questões podem parecer preciosismos ou desperdício de tempo, mas na realidade essas preocupações são partes importantes para o cumprimento do objetivo principal da tradição eletiva criada com a última tendência historiográfica da escravidão e seus desdobramentos, como a lei 10.639. Simplesmente entulhar informações sobre a cultura afro-brasileira não resolve a questão, de tal modo que é necessário fazer compreender a trajetória da luta dos negros escravizados, para aí sim criar sentimentos de reconhecimento e empatia nos estudantes.

Assumir naturalmente a existência de identidades negras ou de uma cultura afro-brasileira é perder a dimensão das lutas travadas em torno da construção de identidades - mestiça, indígena, popular, brasileira ou regional - ao longo da história do Brasil. Sendo assim, é preciso chamar a atenção para a importância de pensar a história dos conceitos da cultura negra (e/ou afro-brasileira) e das identidades negras. (ABREU; MATTOS, 2008, p.9). 


\section{CONSIDERAÇÕES FINAIS}

Mesmo levando em consideração as limitações inerentes a cada metodologia historiográfica utilizada pelas três grandes tendências interpretativas da escravidão no Brasil, é desnecessário e incorreto julgar como errada alguma dessas tendências, de tal modo que o cumprimento de qualquer objetivo de pesquisa passa necessariamente pela escolha adequada do método de análise. Assim sendo, apesar dos elogios e das críticas, cada tendência tem uma contribuição importante em seu próprio campo para o entendimento do fenômeno da escravidão do negro no Brasil.

Além disso, ao historiador cabe sempre buscar compreender as "tradições eletivas" que estão por trás da criação e da escolha de determinada narrativa.

Não obstante, as consequências da última tendência distanciando-se das outras duas - que teve como um de seus legados a lei 10.639/03, tenta criar através dessa lei uma nova tradição eletiva, pensando a escravidão através do próprio escravo, dando voz aos silenciados da História, a fim de contribuir para a inclusão não só legal, mas também cultural do negro na sociedade.

Em suma, a popularidade e escolha da terceira tendência narrativa sobre as outras se justifica pela necessidade do enrijecimento do combate ao racismo - ainda presente na sociedade - e das reinvindicações dos próprios negros de tomarem seu lugar de direito no país que ajudaram a construir com a força de seu trabalho.

Ademais, cabe aos professores e livros didáticos o constante aprimoramento profissional, visto que as exigências são complexas e a temática muito importante. Isso se torna necessário, pois a vontade pela luta contra o racismo e pela divulgação da cultura afro-brasileira passa pelo comportamento ativo de todos os profissionais da educação, que evidentemente não devem necessariamente se tornarem especialistas em História da África ou tentar formar jovens historiadores, mas que sobretudo devem apresentar compromisso com a causa.

\section{REFERÊNCIAS}

ABREU, Martha; MATTOS, Hebe. Em torno das "Diretrizes Curriculares Nacionais para a Educação das Relações Étnico-raciais e para o Ensino de História e Cultura Afro-brasileira e Africana": uma conversa com historiadores. Estudos Históricos, Rio de Janeiro, v. 21, n. 41, jan.-jun. 2008. 
ARAÚJO, Guilherme Lima de. Desdobramentos da Lei 10.639/03 nos livros didáticos de História. TCC (Graduação) - Curso de História, Centro Universitário Barão de Mauá, Ribeirão Preto - SP, 2017.

BRASIL. Diretrizes Curriculares Nacionais para a Educação das Relações Étnico-Raciais e para o Ensino de História e Cultura Afro-Brasileira e Africana. Brasília: MEC/SEF, 2004.

DOMINGUES, Petrônio. Movimento negro brasileiro: alguns apontamentos históricos. Revista Tempo. v.12, n.23, p. 100-122.

FNDE. Edital de Convocação para Inscrição de obras a serem incluídas no Catálogo do PNLD 2019. Brasília: Ministério da Educação, 2017. - Disponível em: https://www.fnde.gov.br/programas/programas-do-livro/consultas/editaisprogramas-livro/item/10521-pnld-2019 acesso em: 10/07/2019

JANZ, Rubia Caroline. Dez anos da lei 10.639/03: o que mudou nos livros didáticos de História? - uma proposta de análise, Anais do XV Encontro Estadual de História "1964-2014: Memórias, Testemunhos e Estado". Florianópolis, 2014.

LE GOFF, Jacques. História e Memória. Tradução Bernardo Leitão. Campinas: SP Editora da UNICAMP, 1990.

ORWELL, George. 1984: São Paulo: Companhia das Letras, 2009.

PALERMO, Luís Claudio. Disputas no campo da historiografia da escravidão brasileira: perspectivas clássicas e debates atuais. Dimensões, v. 39, jul.-dez. 2017, p. 324-347. 


\title{
O DESAFIO DA EDUCAÇÃO INCLUSIVA NA ADOLESCÊNCIA
}

\author{
GALERANI, Thiago da Silva \\ Discente - UFSJ \\ thiago@galerani.com.br
}

\section{INTRODUÇÃO}

A adolescência é uma passagem difícil na vida do estudante. Isso porque trata-se de uma etapa determinante na configuração da personalidade dos indivíduos rumo à vida adulta.

No contexto das relações educacionais, a adolescência demanda cuidados para que não se torne uma experiência pesarosa.

Mais desafiadora ainda é a adolescência da pessoa com deficiência, já que nem sempre os demais estudantes estão preparados para lidar com a diversidade.

O presente estudo, pautado por pesquisa bibliográfica, tem por escopo investigar o problema da marginalização, na vida escolar adolescente, de pessoas com deficiência, e justifica-se porque presta-se a reflexão sobre caminhos para que professores e equipe escolar possam prevenir e combater os processos de marginalização desses estudantes, promovendo a efetiva inclusão.

\section{MÉTODO}

O presente estudo assenta-se em pesquisa normativa, bibliográfica e jurisprudencial.

A pesquisa de normas jurídicas foi realizada junto aos repositórios eletrônicos de normas jurídicas mantidos pelo Senado Federal e pela Câmara dos Deputados. Após levantamento, os textos normativos foram interpretados à luz do material bibliográfico acima referido.

A pesquisa bibliográfica realizada consistiu no levantamento, análise de e interpretação material bibliográfico (livros, artigos e monografias) relacionado ao objeto de pesquisa, com o escopo de compreender e ampliar os valores e conceitos inerentes ao objeto da pesquisa.

A pesquisa jurisprudencial dedicou-se à exegese do Acórdão proferido nos autos da Ação Direta de Inconstitucionalidade (ADI) nํ 5.357, que 
refere-se a judicialização de controvérsia sobre a obrigatoriedade de inclusão das pessoas nas escolas privadas.

\title{
3. A ADOLESCÊNCIA E A MARGINALIZAÇÃO DA PESSOA ADOLESCENTE COM DEFICIÊNCIA
}

A Organização Mundial da Saúde (OMS) situa a adolescência entre 10 e 19 anos.

No Brasil, a faixa etária que abrange a adolescência é regida pela Lei 8.069/1990 (Estatuto da Criança e do Adolescente), que situa a adolescência entre 12 e 18 anos de idade.

COIMBRA et al. (2005) sustentam que o conceito de adolescência serve mormente a propósitos de dominação e alienação para o consumo da sociedade contemporânea:

\begin{abstract}
"Acreditamos que os conceitos de adolescência e desenvolvimento não são ingênuos. Servem aos propósitos dominantes de homogeneização e imobilização, reificando determinadas práticas e relações presentes na atual sociedade de controle globalizado. Os meios de comunicação de massa, por exemplo, estão entre os equipamentos sociais mais poderosos para difundir e reforçar a idéia de adolescência, oferecendo-a como produto a ser consumido, necessariamente, para se ingressar no mundo dos bem-sucedidos e dos que têm valor, tanto material como simbolicamente."
\end{abstract}

Da transcrição acima, infere-se que, segundo as autoras, o conceito de adolescência é uma construção histórica, em especial a partir da sociedade contemporânea de controle globalizado, e que tal conceito vem servindo mormente aos propósitos dominantes de homogeneização e padronização das práticas sociais e dos modos de existência, em benefício dos interesses do capital.

EISEINSTEIN (2005) reconhece a adolescência como uma fase delicada e de muita pressão em vários aspectos da vida dos indivíduos:

Adolescência é o período transição entre a infância e a vida adulta, caracterizado pelos impulsos do desenvolvimento físico, mental, emocional, sexual e social e pelos esforços do indivíduo em alcançar os objetivos relacionados às expectativas culturais da sociedade em que vive.

É na adolescência que as pessoas lidam com o desafio da aquisição da identidade, conforme ensinam ASSIS e AVANCI (2004, p. 12): "A identidade se cristaliza quando o adolescente é capaz de compreender-se e aceitar-se como realmente é, com pontos fortes e fracos, potencialidades e limites." 
O estudante adolescente com deficiência, certamente enfrenta inúmeros desafios nesse processo de autoconhecimento e aquisição da identidade, já que enfrenta barreiras que muitas vezes implicam em marginalização, dentro e fora do ambiente escolar.

No Brasil, nos termos do art. $2^{\circ}$ da Lei ํo 13.146/2015 (Lei Brasileira de Inclusão da Pessoa com Deficiência, também conhecida como Estatuto da Pessoa com Deficiência), considera-se pessoa com deficiência aqueles que têm "impedimento de longo prazo de natureza física, mental, intelectual ou sensorial, o qual, em interação com uma ou mais barreiras, pode obstruir sua participação plena e efetiva na sociedade em igualdade de condições com as demais pessoas."

A Constituição Federal brasileira de 1988 já enunciava que a igualdade é um direito de todas as pessoas. Mesmo assim, sobreveio 0 art. $4^{\circ}$ da Lei 13.146/2015 veio a reafirmar o direito à igualdade da pessoa com deficiência em relação às demais pessoas, asseverando que "toda pessoa com deficiência tem direito à igualdade de oportunidades com as demais pessoas e não sofrerá nenhuma espécie de discriminação."

O Supremo Tribunal Federal, em recente Acórdão sob a relatoria do Ministro Edson Fachin na Ação Direta de Inconstitucionalidade (ADI) no 5.357, reafirmou a importância da proteção à pessoa com deficiência contra qualquer forma de discriminação:

É somente com o convívio com a diferença e com o seu necessário acolhimento que pode haver a construção de uma sociedade livre, justa e solidária, em que o bem de todos seja promovido sem preconceitos de origem, raça, sexo, cor, idade e quaisquer outras formas de discriminação.

Ao proferir Acórdão na ADI no 5.357, o Ministro Edson Fachin prossegue relembrando que a escola pública ou privada encontra-se obrigada a colher, democraticamente, a pluralidade:

A Lei $n^{0}$ 13.146/2015 indica assumir o compromisso ético de acolhimento e pluralidade democrática adotados pela Constituição ao exigir que não apenas as escolas públicas, mas também as particulares deverão pautar sua atuação educacional a partir de todas as facetas e potencialidades que o direito fundamental à educação possui e que são densificadas em seu Capítulo IV.

A ADI no 5.357 versava sobre a obrigatoriedade das escolas privadas de oferecer atendimento educacional adequado $e$ inclusivo às pessoas com deficiência. A Requerente (Confederação Nacional dos Estabelecimentos de Ensino) insurgia-se contra a obrigatoriedade das escolas privadas de oferecer atendimento educacional adequado e inclusivo às pessoas com deficiência, sob o argumetno de que as obrigações advindas da 
Lei 13.146/2015 implicariam em medidas de alto custo para as escolas privadas, o que inviabilizaria o exercício regular de sua atividade econômica. Conforme indica o julgado parcialmente transcrito, acima, o STF concluiu que a Requerente não tinha razão, sendo imprescindível às escolas privadas 0 cumprimento integral dos deveres advindos da Lei 13.146/2015.

O Acórdão acima referido, bem como as normas jurídicas mencionadas no presente estudo, evidenciam que a pessoa com deficiência tem o direito a viver em sociedade isonomicamente, bem como o direito de estar protegida contra discriminação.

Mesmo assim, em se tratando de pessoa adolescente com deficiência, muitas vezes esse processo de aquisição da identidade típico da adolescência torna-se mais difícil no contexto das relações educacionais, já que culturalmente, no Brasil, ainda impera a marginalização da pessoa com deficiência, inclusive no ambiente escolar, onde fatores como a prática bullying ainda encontram morada.

A Lei 13.185/2015 instituiu o Programa de Combate à Intimidação Sistemática, caracterizando em seu art. $2^{\circ}$ a intimidação sistemática (ou bullying) como a "violência física ou psicológica em atos de intimidação, humilhação ou discriminação".

A despeito do farto imperativo legal acima transcrito, muitos desafios repousam quanto a esses fatores no desenvolvimento saudável do adolescente com deficiência, dentro e fora do ambiente escolar. DAZZANI (2010) afirma que "a escola inclusiva não poderá ser só uma escola que acolhe as pessoas com necessidades educativas especiais, mas uma escola democrática."

A marginalização do adolescente com deficiência é uma barreira que precisa ser transposta quando a escola se assume o desafio da inclusão, afinal, a marginalização é um mecanismo de exclusão social. Nesse sentido, eis a lição de CALIMAN (2006):

"O conceito de marginalidade faz referências a um sistema (ou a sistemas sociais) em relação ao qual o sujeito ou o grupo são considerados como periféricos. Compreende, portanto, a definição da posição ocupada pelo sujeito e do objeto do qual ele é excluído. O sistema social se desenvolve dentro da sociedade mais ampla. Compreende um setor da sociedade caracterizado por uma 'organização' e por uma 'legitimação interna' que correspondem ao tipo de racionalidade do próprio sistema."

Exemplificando: se o estudante adolescente passa a sofrer bullying em razão de seu status de pessoa com deficiência, estará configurado, portanto, um processo de marginalização que representará uma forte barreira 
contra o aprendizado desse estudante e da aquisição saudável da identidade que é própria da adolescência.

CALIMAN (2006) também discorre sobre os efeitos da marginalidade, que seriam, em síntese, a exclusão dos direitos, das decisões, dos recursos e dos privilégios prometidos a todos mas que são efetivamente direcionados a uma minoria:

\begin{abstract}
A marginalidade tem suas origens na escassa possibilidade de participação: mesmo que os direitos sejam iguais para todos, as reais oportunidades de exercitá-los resultam muito superiores para determinados grupos de indivíduos mais "incluídos" e "integrados" ao centro do sistema.
\end{abstract}

Quando um adolescente sofre discriminação por tratar-se de pessoa com deficiência, efetiva-se a exclusão social. $O$ mecanismo de exclusão, segundo CALIMAN (2006), muitas vezes advém de fatores externos à organização escolar, o que não a isenta de responsabilidade quanto aos problemas dela decorrentes: "Muitos dos problemas dos quais apenas acenamos encontram suas origens fora da escola. Outros são criados e/ou reforçados dentro dela mesma."

O estudante marginalizado caminha na contramão da inclusão, restando vulnerabilizado, com grande probabilidade de apresentar dificuldades no rendimento escolar, problemas com manifestações de agressividade, dificuldades de adaptação ao papel educacional do estudante, dificuldade de interagir em sociedade, entre outras.

\title{
4. CAMINHOS PARA PREVENIR E ERRADICAR A MARGINALIZAÇÃO DA PESSOA ADOLESCENTE COM DEFICIÊNCIA
}

A escola que se opõe à marginalização do estudante adolescente com deficiência é a escola inclusiva. A escola inclusiva revela-se democrática, acolhedora e disponível. Mas para que se possa promover a efetiva inclusão, insta considerar estrategicamente tudo o que se relaciona com a escola: os processos sociais, os processos de produção de identidade, enfim, tudo aquilo que afeta os sujeitos envolvidos - inclusive a violência, o sofrimento, os constrangimentos, o bullying, os sonhos, etc.

HOOKS (2017, p. 51) preleciona o educador precisa equacionar em suas práticas a necessidade de respeito ao multiculturalismo:

(...) a maioria de nós frequentamos escolas onde o estilo de ensino refletia a noção de uma única forma de pensamento e experiência, a qual éramos encorajados a crer que fosse universal. (...) A maioria de nós aprendemos a ensinar imitando esse modelo. Como 
consequência, muitos professores se perturbam com as implicações políticas de uma educação multicultural, pois têm medo de perder 0 controle da turma caso não haja um modo único de abordar um tema, mas sim modos múltiplos e referências múltiplas.

Para Hooks, a escola democrática é aquela que revela-se aberta ao multiculturalismo. Assim, as instituições educacionais carecem, para que sua atuação seja transformadora, de promover 0 acolhimento ao multiculturalismo e à diversidade.

SHIMONO (2008, p. 110) sustenta que é preciso avaliar, preliminarmente, o compromisso dos educadores com seu ofício de educar, já que "na escola pública ou particular os sujeitos enfrentam muita desinformação e despreparo de professores, ambientes pouco acolhedores." Logo, segundo a autora, é preciso investir na capacitação docente para lidar com as necessidades dos estudantes com deficiência, sendo necessária, também, a configuração da escola como espaço pedagógico receptivo à pessoa com deficiência.

CANDIDO e CARNEIRO (2018) afirmam que as Tecnologias de Informação e Comunicação (TICs) têm grande valia para servir como aporte para o acesso à educação de pessoas com deficiência:

Através das TICs é possível criar possibilidades de ambientes de aprendizagem onde as identidades sejam respeitadas e cada aluno possa se sentir acolhido para o processo educacional, sendo parte integrante do sistema de ensino de modo útil e participativo.

Com base em todo o exposto, não vislumbra-se, quanto ao resultado da pesquisa bibliográfica realizada, um único caminho, tampouco um modelo ou prática pedagógica infalível para promover a inclusão do adolescente com deficiência, o que não isenta as instituições educacionais quanto ao dever jurídico de buscar a inclusão, tanto no âmbito do ensino público quanto no ensino privado.

\section{CONSIDERAÇÕES FINAIS}

A pesquisa bibliográfica desenvolvida não resultou na identificação de um caminho único para a promoção da inclusão do estudante adolescente com deficiência. No entanto, foi possível a identificação de algumas ponderações que merecem atenção no enfrentamento à questão, especialmente as seguintes:

- É preciso investir na formação docente para a promoção da inclusão educacional de pessoas com deficiência; 
- É preciso tornar o ambiente escolar acessível e acolhedor ao estudante com deficiência;

- É preciso conscientizar toda a comunidade escolar no sentido de combate aos preconceitos, promovendo a inclusão, respeitando a diversidade e a multiculturalidade;

- É preciso lançar mão, quando possível, de recursos tecnológicos que possam auxiliar no processo de inclusão dos estudantes com deficiência;

- É salutar trabalhar para que os preconceitos e fatores alheios à escola não interfiram negativamente no trabalho de inclusão.

A pesquisa normativa e jurisprudencial realizada evidencia que é um direito do adolescente com deficiência a proteção contra discriminação e o acesso ao ensino de forma isonômica e com qualidade, tanto na escola pública quanto na escola privada.

Muitos dos fatores que afetam negativamente o desenvolvimento e construção da autoimagem do adolescente excluído podem originar-se fora da escola.

Se a marginalização inviabiliza a inclusão do aluno adolescente com deficiência, deve-se criar as condições para uma convivência educacional saudável e paritária, para que a inclusão efetivamente ocorra e a dimensão educacional da escola seja bem-sucedida. Não basta que a escola seja acessível, não basta que equipe e professores sejam qualificados para atender ao sujeito com deficiência: é preciso combater, democraticamente, todo e qualquer fator de marginalização, promovendo a escola acolhedora e a qualidade do ensino para todos.

\section{REFERÊNCIAS}

ASSIS, Simone Gonçalves; AVANCI, Joviana Quintes. A visão que os adolescentes têm de si: imagens nos espelhos. Disponível em: $<$ http://books. scielo.org/id/vdywc/pdf/assis-9788575413333-04.pdf $>$. Acesso em: 01 Jun. 2019.

BRASIL. Constituição Federal de 1988. Disponível em: $<$ http://www.planalto.gov.br/ccivil_03/constituicao/constituicao.htm>. Acesso em: 30 Ago. 2019.

BRASIL. Lei 8.069, de 13 de Julho de 1990. Disponível em: $<$ http://www.planalto.gov.br/ccivil 03/leis/18069.htm>. Acesso em: 30 Ago. 2019.

BRASIL. Lei 13.146, de 6 de Julho de 2015. Disponível em: $<$ http://www.planalto.gov.br/ccivil 03/ ato2015-2018/2015/lei/l13146.htm>.

Acesso em: 30 Ago. 2019. 
BRASIL. Lei 13.185, de 6 de Novembro de 2015. Disponível em: $<$ http://www.planalto.gov.br/ccivil 03/ ato2015-2018/2015/lei//13185.htm>. Acesso em: 30 Ago. 2019.

CALIMAN, Geraldo. Estudantes em situação de risco e prevenção. Disponível em: $<$ http://www.scielo.br/scielo.php?script=sci arttext\&pid=S010440362006000300007\&lng=en\&nrm=iso >. Acesso em: 08 Jun. 2019.

CANDIDO, Eliane Aparecida Piza; CARNEIRO, Relma Urel Carbone. A tecnologia como aporte para o acesso a educação de pessoas com deficiência. Disponível em: $<$ https://www.uninter.com/intersaberes/index.php/revista/article/download/1350/ 414234>. Aceso em 01 Set. 2019.

COIMBRA, Cecília; BOCCO, Fernanda; NASCIMENTO, Maria Livia do.

Subvertendo o conceito de adolescência. Arq. bras. psicol., Rio de Janeiro , v. 57, n. 1, p. 2-11, jun. 2005 . Disponível em $<$ http://pepsic.bvsalud.org/scielo.php?script=sci arttext\&pid=S1809$\underline{52672005000100002 \& \operatorname{lng}=\text { pt\&nrm=iso }}$. Acesso em: 02 Set. 2019.

DAZZANI, Maria Virgínia Machado. A psicologia escolar e a educação inclusiva: Uma leitura crítica. Disponível em: $<$ http://www.scielo.br/scielo.php?script=sci arttext\&pid=S141498932010000200011\&lng=en\&nrm=iso >. Acesso em: 08 Jun. 2019.

EISENSTEIN, Evelyn. Adolescência: definições, conceitos e critérios. Disponível em: $<$ http://adolescenciaesaude.com/audiencia pdf.asp?aid2 $=167$ \&nomeArquivo $=\mathrm{v}$ 2n2a02.pdf >. Acesso em: 07 Jun. 2019.

HOOKS, Bell. Ensinando a transgredir: a educação como prática da liberdade. São Paulo:WMF Martins Fontes, 2017, 283 p.

SHIMONO, Sumiko Oki. Educação e trabalho: caminhos da inclusão na perspectiva da pessoa com deficiência. Disponível em:

$<$ https://www.ufpr.cleveron.com.br/arquivos/EP 104/dissertacao trabalho inclu sao.pdf>. Acesso em 20 Jun. 2019.

STF. AÇÃO DIRETA DE INSCONSTITUCIONALIDADE: ADI 5.357 DF 0005187-75.2015.1.00.0000. Relator: Ministro Edson Fachin. DJ: 07/03/2017. STF, 2017. Disponivel em: $<$ http://portal.stf.jus.br/processos/downloadPeca.asp?id=311341726\&ext=.pdf $>$. Acesso em: 30 Ago. 2019. 


\title{
O ENSINO DO DIREITO COMO MÉTODO DE PROMOÇÃO DA CULTURA DA PAZ
}

\author{
MARCICO, Bianca \\ Mestranda - UNESP \\ LOPES, Eduardo Matheus Ferreira \\ Mestrando - UNESP \\ DEGRANDE, Pedro Alexandre F. S. \\ Bacharel - UNESP
}

\section{INTRODUÇÃO}

O presente trabalho foi elaborado em razão da demanda social apresentada pela necessidade de se modificar a cultura jurídica brasileira, porquanto o número de litígios judiciais apresenta crescimento exponencial, de acordo com os números oficiais. $\mathrm{O}$ trabalho se desenvolve com o intuito de se perquirir como a própria manifestação dos mecanismos do ensinoaprendizagem dentro do universo jurídico se prestam a reforçar essa cultura litigante. Neste aspecto, um primeiro conceito que é essencial a este trabalho é o de "cultura da paz":

\begin{abstract}
A base da cultura da paz é a atitude de não-violência. Ao contrário do que parece ao senso comum, não-violência não é sinônimo de resignação, passividade, mas pressupõe uma resposta ativa, uma ação a partir do reconhecimento do conflito e da luta. [...] A cultura de paz está intimamente associada ao desenvolvimento da tolerância, a qual pressupõe identificação com a subjetividade do outro (alteridade), o reconhecimento da diversidade e abertura para 0 convívio (viver junto). (BRAGA, 2012, p. 35)
\end{abstract}

Um outro paradigma importante, que será central neste texto, é o conceito de "Ecologia dos Saberes", formulada pelo sociólogo português Boaventura de Sousa Santos como uma ferramenta de alternativa epistêmica aos saberes eurocêntricos e do norte global. Nos termos do autor:

Como ecologia de saberes, o pensamento pós-abissal tem por premissa a idéia da inesgotável diversidade epistemológica do mundo, o reconhecimento da existência de uma pluralidade de formas de conhecimento além do conhecimento científico. Isso implica renunciar a qualquer epistemologia geral. Existem em todo o mundo não só diversas formas de conhecimento da matéria, da sociedade, da vida e do espírito, mas também muitos e diversos conceitos e critérios sobre o que conta como conhecimento. (SANTOS, 2007, p. 85-86) 
Neste sentido, defende-se que a noção de uma cultura jurídica "pós-abissal" pode contemplar o raciocínio que permeia a proposta dos métodos alternativos de resolução de conflito e de promoção da paz. Parte-se da premissa de um saber e de uma prática horizontalizados, os quais rompem com as linhas "abissais" imaginárias que segregam as partes em oposição, a fim de que a solução, no caso da lide, e o saber, no caso do ensino jurídico, sejam construídos coletivamente.

\section{METODOLOGIA DE PESQUISA}

Utilizou-se, para este trabalho, a metodologia hipotético-dedutiva, através de uma ferramenta de revisão bibliográfica analítica acerca das principais obras que foram desenvolvidas por Boaventura de Sousa Santos (2002; 2006; 2007; 2010), em especial nos aspectos em que o autor pode influenciar a (re)construção da teoria jurídica brasileira, especialmente seu ensino jurídico, a fim de que se promova uma cultura de conciliação e paz, em lugar da atual litigiosidade.

\section{DISCUSSÕES}

Numa sociedade cada vez mais integrada em termos comunicacionais, a natureza dos próprios conflitos torna-se mais variada e mais complexa. Os juristas, em geral, têm percebido que os tradicionais meios atribuídos ao Poder Judiciário já não conseguem suprir todas as demandas da sociedade do século XXI. Numericamente, conforme dados do próprio Conselho Nacional de Justiça (CNJ), em seu relatório "Justiça em Números", a chamada "taxa de congestionamento" 3 do Judiciário nacional atinge $67 \%$ das ações em trâmite - dois terço de cada um dos processos promovidos no Brasil. Importa a esta pesquisa salientar que este número foi a menor taxa percentual desde o início da apuração histórica destes dados (CNJ, 2019, p. 95).

O mesmo órgão administrativo dera início, no ano de 2004, ao levantamento estatístico dos dados dos diversos Tribunais de Justiça das unidades federativas brasileiras. Em 2019, o relatório elaborado pelo mesmo programa "Justiça em Números"4 apresentou a informação de que o Brasil despendeu, no ano orçamentário de 2018, um total de $\mathrm{R} \$ 93.725 .289 .276,00$ (CNJ, 2019, p. 34) para a manutenção dos Tribunais.

\footnotetext{
${ }^{3}$ A taxa de congestionamento mede o percentual de processos que ficaram represados sem solução, comparativamente ao total tramitado no período de um ano. (CNJ, 2019, p. 95)

${ }^{4}$ Os dados foram apurados para o ano de 2018 e compilados no relatório publicado em 2019.
} 
Não bastasse esse número exorbitante, retirado do erário, apurou-se que na Justiça Estadual, instância na qual tramitam cerca de 80 \% dos processos do país (ibid. p. 80), o tempo médio de tramitação até a sentença de $1^{\circ}$ grau é de dois anos e quatro meses (ibid. p. 39). Em 2018 "existiam 64,6 milhões ações judiciais" (ibid. p. 79), com a indicação de mais de $10 \%$ da população tendo ingressado com ação judicial (ibid. p. 84).

Autores como TRIGUEIRO E BORGES (2015, p. 6-7) apontam a existência de múltiplas demandas sobre discussões frívolas, bem como o incentivo à cultura litigante como parte de um mercado advocatício saturado que se encontra com um mecanismo de acesso formal ao poder judiciário além de uma profusão de população desinformada sobre seus direitos. Neste diapasão, a mediação e a conciliação são meios até mesmo menos desgastantes para as partes envolvidas, já que possibilitam, efetivamente, um diálogo em busca de uma solução, não somente o mero confronto de ideias e pretensões.

O Código de Processo Civil (CPC) brasileiro, promulgado em 2015, apresenta o estímulo às práticas de conciliação e mediação como duas de suas normas fundamentais e essenciais5. Inclui-se o estímulo à autocomposição como um dos deveres do Juiz6; traz a figura do mediador e do conciliador como auxiliares do Juízo, com a dedicação de uma seção inteira do diploma legal para estabelecimento de diretrizes de atuação, bem como impõe necessidade de realização da audiência preliminar de conciliação e mediação como um dos pilares do processo novo processo civil7. Percebe-se, portanto, que o legislador nacional, atento às novas demandas sociais, positivou institutos construídos doutrinariamente a fim de que se fortalecesse a cultura jurídica da autocomposição, com a consensualização8 do Poder Judiciário. Nesse sentido:

Em suma, mais do que comprovadamente acelerar o processo de resolução de disputas, a conciliação e mediação judicial permitem dirimir lides sociológicas. Estas práticas de consensualização da justiça proporcionam a recontextualização do papel do Poder Judiciário afastando-se de posições singularistas segundo as quais para cada conflito de interesse só pode haver uma solução correta a do magistrado, que sendo mantida ou reformada em grau recursal, torna-se a "verdadeira solução" para o caso. A ideia de que o jurisdicionado, quando busca o Poder Judiciário, o faz na ânsia de receber a solução de um terceiro para suas questões vem progressivamente sendo alterada para uma visão de estado que oriente as partes para que resolvam de forma mais consensual e

\footnotetext{
${ }^{5}$ Conforme se colaciona excerto do Código de Processo Civil: “Art. 3이...] § 3ㅇA A conciliação, a mediação e outros métodos de solução consensual de conflitos deverão ser estimulados por juízes, advogados, defensores públicos e membros do Ministério Público, inclusive no curso do processo judicial."

${ }^{6}$ Cf. Código de Processo Civil: "Art. 139 [...] V - promover, a qualquer tempo, a autocomposição, preferencialmente com auxílio de conciliadores e mediadores judiciais;"

${ }^{7}$ Cf. Código de Processo Civil - Art. 334.

${ }^{8}$ Termo proposto por AZEVEDO e DUZZI.
} 
amigável seus próprios conflitos e, apenas excepcionalmente, como última hipótese, se decidirá em substituição às partes. Assim, na autocomposição, podem existir diversas respostas concomitantemente corretas (e legítimas) para uma mesma questão. Nessa hipótese, cabe às partes construírem a solução para suas próprias questões e, assim, encontrarem a resposta que melhor se adeque ao seu contexto fático. (AZEVEDO e BUZZI, 2016, p. 3-4)

Contudo, apesar dos mecanismos elencados na nova legislação em vigor, impõe informar que a mera declaração formal de determinado instituto não possui o condão de transformar a realidade subjacente que informa esse sistema. Nesse sentido, TRIGUEIRO e BORGES (2015, p. 10) propõe a elaboração de estratégias para a informação das partes e partilha de informações, entre os pólos do processo, como possibilidade de se efetivar a real materialização de um processo judicial menos oneroso ao Estado e às partes.

A prática da mediação entre as partes em conflito, pode ser entendida, pela doutrina, como um

\begin{abstract}
[...] instituto com natureza jurídica própria e distinta da autotutela, é um recurso relevante para a resolução de conflitos. É regido pelos princípios da confidencialidade $e$ da voluntariedade. A responsabilidade pela elaboração e realização das decisões é das partes envolvidas. Ou seja, o poder decisório na mediação é dos cidadãos e das cidadãs. É instrumento de política pública, direcionada à distribuição da justiça social e da formação de uma cultura de paz. (HENRIQUE, 2012, p. 206)
\end{abstract}

Por sua vez, a conciliação é uma política adotada pelo CNJ desde 2006, ano no qual houve a implantação do projeto de "Movimento pela Conciliação". O evento, agora realizado em periodicidade anual, se realiza sob o nome de "Semanas Nacionais pela Conciliação" ocasião em que se busca o incentivo à realização de acordos nas fases pré-processual e processual. (CNJ, 2019, p.142). Desde 2010 o CNJ promove o prêmio "conciliar é legal" que reconhece práticas alternativas para a resolução consensual de conflitos 9 , 0 que se coaduna com os objetivos de redução das taxas de congestionamento e maior eficiência do poder judiciário.

Outro aspecto importante das práticas de conciliação e da mediação é que por se tratarem de uma solução consensual, acaba por reduzir a incidência de recursos em processos judiciais, uma das principais causas de congestionamento na tramitação dos litígios brasileiros (ibid. passim.). As técnicas de autocomposição, como o próprio nome sugere, impõem 0 protagonismo da decisão às partes que são envolvidas; trata-se, portanto, de uma prática emancipatória, a qual desloca o eixo processual do estado-juiz

\footnotetext{
${ }^{9}$ Para maiores informações sobre o prêmio - Cf. https://www.cnj.jus.br/programas-e-acoes/conciliacao-emediacao-portal-da-conciliacao/premio-nacional-da-conciliacao. Acesso em 05 set. 2019.
} 
para se aprimorar a figura do juiz-intermediador. Nesse sentido, AMANCIO FILHO (2019) afirma que

A conciliação é método de fazer com que as partes sejam os próprios protagonistas de sua ação, é retirar momentaneamente a figura do poder do Estado, através do juiz, fazendo com que elas mesmas reflitam e debatam soluções para suas causas, avaliando cada consequência que sua vida terá no futuro decorrente das decisões que tomarem naquele momento. Ou seja, tem como objetivo a promoção do diálogo entre as partes, preocupando-se mais com a pacificação social do que com o acordo propriamente dito, que será uma consequência de um bom diálogo. Porém, para se obter a pacificação, é necessária uma mudança de hábitos enraizados na cultura do Direito. (p. 07)

[...] Em audiências conciliatórias ocorridas com assistência de advogado particular, o andamento na construção de ideias é interrompido por exposições técnicas que muitas vezes não contribuem em atender o maior interesse da parte. $O$ tratamento do cidadão como cliente, por parte do advogado, implica deixar de ouvir a pessoa humana, sua história com relação ao fato gerador do conflito e o objetivo com determinada ação e passa visar o caminho que seja mais lucrativo. Mas isso não é uma culpa exclusiva do advogado que o pratica. Trata-se de uma cultura enraizada ainda no princípio da carreira, quando ainda se é acadêmico. As faculdades de Direito não ensinam a prática da conciliação, mas apenas o litígio, a briga, a argumentação "a" versus argumentação "b", o que acarreta prejuízos. (p.13)

Assim, como elaborado pelo autor, muito embora as técnicas que são ditas - alternativas para a resolução de conflitos possam indicar um caminho apto à superação da cultura litigante e à materialização da justiça estatal, há que se (re)pensar o ensino e o estudo do direito nas universidades. Essa reformulação se faz necessária a fim de que os profissionais do futuro, em lugar de buscarem uma atuação baseada no "ganhar" ou "perder" os seus processos, possam vislumbrar as demandas enquanto mecanismos que possibilitam às partes a realização de uma justiça, no seu escopo pleno de pacificação social.

O processo de ensino-aprendizagem ocorre no interior de cada ser humano. Ainda que pareça o óbvio, em nosso sentir é necessário plantar bem esse conceito, desenvolvido com mais vagar na nossa formação pedagógica, visto que acreditamos e explicitamos que os conteúdos profissionalizantes e de Direitos Humanos tratados em nossos encontros devem ser conhecidos, aplicados, questionados, julgados, transformados e transformadores, modificados e modificadores. Na pedagogia libertadora de Freire tanto educadores quanto educandos elaboram seus saberes sobre as realidades de inclusão e exclusão social e aprimoram seus instrumentos de intervenção nesses espaços fáticos. (HENRIQUE, 2012, p. 211)

Ainda no mesmo sentido do que elencamos outrora, incumbe dizer que parte da questão apresentada pode ser baseada na necessidade que o ser humano possui de se desvincular do outro, que, no entanto, não pode ser suprida, pois como BAUMAN (2010:96) afirma "A dependência de meu irmão é o que me faz um ser ético. A dependência e a ética estão juntas, e juntas elas caem." Ocorre, portanto, que estamos inseridos em uma sociedade global de 
lógica de funcionamento individualista, a qual necessita a superação das ideias de alteridade enquanto fundamento de uma luta de opostos.

À essa perspectiva, de superação das alteridades, conquanto único mecanismo apto à constituir um processo judicial consensual somente pode ser alcançada mediante a própria mudança epistêmica. A percepção dos saberes que incluem o conflito e a divergência enquanto processos comuns à vida em sociedade, perpassa, necessariamente, pela superação dos abismos entre os processos de construção do conhecimento atuais.

Nesse aspecto Boaventura de Sousa Santos se apresenta como um expoente teórico a ser considerado como base para uma reflexão da cultura jurídica que desloca a construção do pensamento jurídico pátrio da mera absorção e reprodução do conhecimento produzido no "norte global", para a produção de saberes e práticas do Sul e pelo Sul - noutras palavras: tendo ciência de características sócio-políticas periféricas e colonizadas que moldam a cultura institucional (e ocidental) brasileira:

O colonialismo terminou enquanto relação política mas não enquanto relação social, permanecendo sob a forma da colonialidade do poder. Nas relações entre o Norte e o Sul, entre o centro e as periferias do sistema mundial, a colonialidade do poder é, desde o século XIX e hoje mais do que nunca, um efeito da colonialidade do saber científico. (SANTOS, 2006, p. 79)

No mesmo sentido, o raciocínio que se propõe, a fim de interconectar esses dois campos do conhecimento, caminha no sentido de construir com a sociedade e, especialmente, com acadêmicos do direito no Brasil, um (re)pensar das estruturas que formam a conhecimento jurídico tradicionalmente estabelecido, conquanto única forma de modificar a sua base estrutural:

\footnotetext{
De fato, a ênfase num projeto pedagógico aplicado à constituição de uma cultura jurídica humanizadora do Direito representa uma meta urgente a ser concretizada. Educar e tornar-se autônomo, emancipado, são premissas para o processo de conscientização política e de vivência solidária, condições básicas para tornar-se um aplicador do Direito consciente. [...] Cuida-se, primordialmente, de acionar dinâmicas pedagógicas que privilegiem o diálogo plural e que permitam a solidificação dos ideais democráticos e da justiça social. O espaço destinado à leitura e à formação de alunos em sintonia com a cultura dos direitos humanos propicia uma geração de cidadãos mais comprometida com a alteridade, ponto nuclear da realização da Justiça. (BENTES, 2012, p. 104)
}

Assim, a efetivação de um pensamento "pós-abissal" (SANTOS, 2007, p. 90), se coaduna com a perspectiva da expansão da mediação e da conciliação enquanto métodos que mudam o foco de protagonismo do processo judicial, a fim de repensar a hierarquia que sustenta o sistema como um todo. Para tanto, se faz necessária a superação do colonialismo interno a fim de que os saberes das partes possam ser partes integrantes do processo, como perspectivas aptas à solução da lide. 


\section{CONCLUSÕES}

A reaproximação dos diversos mecanismos de construção dos saberes com o reconhecimento da importância de todos os seres humanos no seio das relações sociais é apta e ideal a criar a chamada "cultura da paz". Ao se dissolver as relações de hierarquia entre as partes, especialmente no direito, não se propõe o abandono das premissas da metodologia científica, mas sim a permissão para as novas abordagens epistêmicas, além daquelas tradicionais das possibilidades inter e transdisciplinares. Há que se apontar que a academia tal como convencionalmente estabelecida - em especial em ciências humanas e sociais aplicadas, como a jurídica - dissocia o seu objeto de estudo de seu sujeito pesquisador.

A mediação e conciliação, institutos dois prestigiados pelo novo CPC, trazem luz a uma nova perspectiva que se correlaciona esses aspectos epistemológicos dos saberes inclusivos, que valorizam a resolução ou um aspecto finalístico e não necessariamente deôntico (o que "deve ser"). Assim, é melhor uma solução, ainda que não normativamente prevista, que consiga restabelecer o equilíbrio entre as partes, e emerge do saber empírico subjetivo que as partes trazem à mesa de conciliação, a fim de superar o aspecto tradicionalista, porquanto se entende que é menos passível de insatisfação social.

\section{REFERÊNCIAS}

AMÂNCIO FILHO, José Diniz da Cruz. Métodos consensuais de resolução de conflitos: A conciliação, mediação e constelação como instrumentos de pacificação Social. (Orient.) Thiago Deiglis de Lima Rufino. GUARABIRA: UNISC, 2019. Disponível em: https://online.unisc.br/acadnet/anais/index.php/sidspp/article/view/19645. Acesso em 03 set. de 2019.

AZEVEDO, André Gomma de. BUZZI, Marco Aurélio. Novos desafios para a mediação e conciliação no novo CPC: artigo 334. Publicado por CONJUR, em 11 de novembro de 2016, 6h00. Disponível em: https://brasiljuridico.com.br/img/landingpages/mediacao-extrajudicial/artigoandre-e-marco.pdf. Acesso em 03 set. de 2019.

BAUMAN, Zygmunt. A sociedade individualizada: Vidas Contadas e Histórias vividas. Trad. José Gradel. Rio de Janeiro: Jorge Zahar Ed., 2008.

BENTES, Hilda Helena Soares. Direitos Humanos e Mediação. In: BENTES, Hilda Helena Soares; SALLES, Sérgio de Souza. Mediação e Educação em Direitos Humanos. Rio de Janeiro: Lumen Juris, 2012, 227 p. 
BRAGA, Ana Gabriela Mendes. Cultura de paz, mediação e Justiça Restaurativa: ferramentas para repensar a relação Sociedade-Cárcere. In: BENTES, Hilda Helena Soares; SALLES, Sérgio de Souza. Mediação e Educação em Direitos Humanos. Rio de Janeiro: Lumen Juris, 2012, 227 p.

BRASIL. LEI № 13.105, DE 16 DE MARÇO DE 2015. Código de Processo Civil. Disponível em: http://www.planalto.gov.br/ccivil_03/_ato20152018/2015/lei/l13105.htm. Acesso em 03 set. de 2019.

CABRAL, Trícia Navarro Xavier. A evolução da conciliação e mediação no Brasil. Revista FONAMEC - Rio de Janeiro, v.1, n. 1, p. 368 - 383, maio 2017. Disponível em: http://www.emeri.tiri.jus.br/revistas/fonamec/volumes/volumel/revistafonamec n umero1volume1 368.pdf. Acesso em 03 set. de 2019.

CNJ - Conselho Nacional de Justiça. Justiça em números 2019. Brasília: CNJ, 2019. Disponível em: https://www.cnj.jus.br/files/conteudo/arquivo/2019/08/4668014df24cf825e71873 83564e71a3.pdf. Acesso em 03 set. de 2019.

HENRIQUE, Simone. Mediação e Educação em Direitos Humanos na Educação Profissional: para a Cultura de paz. In: BENTES, Hilda Helena Soares; SALLES, Sérgio de Souza. Mediação e Educação em Direitos Humanos. Rio de Janeiro: Lumen Juris, 2012, 227 p.

PINHO, Humberto Dalla Bernardina de. O novo CPC e a mediação: Reflexões e ponderações. Brasília, ano 48 n. 190 abr.jun. 2011 p. 219-235. Disponível em:

https://www2.senado.leg.br/bdsf/bitstream/handle/id/242895/000923117.pdf. Acesso em 06 de set. 2019.

SANTOS, Boaventura de Sousa. Conocer desde el Sur: Para una cultura política emancipatoria. 1 ed. Lima: Fondo Editorial de la Facultad de Ciencias Sociales, 2006.

SANTOS, Boaventura de Sousa. Descolonizar el saber, reinventar el poder. Montevideo: Ediciones Trilce-Extensión universitaria e Universidad de la República, 2010.

SANTOS, Boaventura de Sousa. Para além do pensamento abissal: das linhas globais a uma ecologia de saberes. In: Novos Estudos, n. 79, nov. 2007, p. 71-94

SANTOS, Boaventura de Sousa. Reinventar a Democracia. 2 ed. Lisboa: Gradiva Publicações - LTDA, 2002.

SPENGLER, Fabiana Marion. SARAIVA, Amanda da Cruz. Meios Alternativos de Solução de Conflitos: Conciliação, mediação e arbitragem como formas de desburocratizar o judiciário, à luz do novo código de processo civil. Disponível em: http://dspace.bc.uepb.edu.br/jspui/handle/123456789/19930. Acesso em 03 set. de 2019. 
TRIGUEIRO, Victor Guedes. BORGES, João Paulo Resende. Análise econômica da litigância: pressupostos básicos e o código de processo civil de 2015. Revista Eletrônica de Direito Processual - REDP. Rio de Janeiro. Ano 13. Volume 20. Número 2. Maio a Agosto de 2019. Periódico Quadrimestral da Pós-Graduação Stricto Sensu em Direito Processual da UERJ. Patrono: José Carlos Barbosa Moreira (in mem.). ISSN 1982-7636. pp. 313-338. Disponível em: $\quad$ https://www.e-publicacoes.ueri.br/index.php/redp/article/view/44561. Acesso em 03 set. de 2019. 


\title{
OS ARGUMENTOS JURÍDICOS A FAVOR DO DEBATE SOBRE
} GÊNERO NAS ESCOLAS

\author{
PEREIRA, Flávio Macarini \\ Mestrando em Direito - UNESP/Franca \\ flavio.mp@gmail.com
}

\section{INTRODUÇÃO}

Entre 2014, as discussões em torno do Plano Nacional da Educação ocasionam debates e conflitos intensos no Congresso Nacional em relação à inclusão de temas como diversidade e orientação sexual, gênero e educação sexual. Um conjunto de parlamentares e setores da sociedade civil se mobilizaram contra a inclusão desses temas no documento e no currículo escolar e foi comum entre esse grupo o uso do termo "ideologia de gênero" para se referir aos temas em debate.

A partir desse episódio, esses setores da sociedade iniciam uma ampla mobilização com o intuito de ampliar sua influência, angariar aliados e garantir o predomínio de suas posições em relação à educação e ao currículo escolar.

Essa mobilização deu resultados positivos para os adversários da "ideologia de gênero". Certos representantes dos poderes executivos e legislativos nas esferas municipais aderiram à pauta e estabeleceram legislações próprias sobre o tema, proibindo que tais assuntos fossem discutidos nas escolas.

Em reação a esse movimento, grupos a favor do debate de gênero e das causas LGBT (lésbicas, gays, bissexuais e transexuais) buscam suas próprias formas e meios de mobilização. Um dos caminhos possíveis de serem tomados neste embate é a provocação do judiciário para intervir nos atos vindos do Poder Público.

Atualmente, estão em curso dez Arguições de Descumprimento de Preceito Fundamental que buscam declaração de inconstitucionalidade de legislações municipais que proíbem a discussão de gênero e diversidade sexual em sala de aula.

O objetivo deste trabalho é contribuir com a compreensão de como os debates "de gênero" se relacionam com a ordem jurídica nacional e 0 sistema de direitos constitucional. Para isso, analisou os argumentos e dispositivos normativos constitucionais mobilizados pelos autores utilizaram em suas petições iniciais ao propor essas ações. 
O trabalho é separado em três momentos. No primeiro será discutida a origem e significado da expressão "ideologia de gênero" e sua relação com as mobilizações e debates políticos. No segundo, serão discutidas as particularidades deste tipo de ação e sua relação com a ordem constitucional. No terceiro, momento serão apresentadas as ações, seus argumentos e os dispositivos constitucionais mobilizados.

\section{A IDEOLOGIA DE GÊNERO}

Segundo Andrea Dip (2018), o termo não é utilizado academicamente na área de Estudos de Gênero, um campo multidisciplinar que discute temas relacionados à sexualidade, posições sociais de gênero, novos arranjos familiares e o reconhecimento da diversidade sexual e de gênero, dentre outros temas relacionados. A partir desse campo de estudos convencionou-se utilizar o termo sexo para se referir aos atributos biológicos, físicos e anatômicos do corpo humano. Enquanto gênero é de origem social e cultural e está relacionado com comportamentos, capacidades e papéis. $O$ conceito de gênero surge como parte da contestação da perspectiva da inferioridade feminina por questões biológicas.

É uma definição que se desdobrou a partir da dicotomia entre natureza e cultura, do debate entre as "ciências da natureza" e as "ciências do espírito" que se iniciou no século XIX. Contemporaneamente, a discussão coloca os termos "sexo" e "gênero" para se referir, respectivamente, às características bioquímicas e fisiológicas e aos aspectos subjetivos e culturais do que é ser homem ou mulher (OKA; LAURENTI, 2018).

Os autores Richard Miskolci e Maximiliano Campana (2017) apontam que os debates sobre o que viria a ser conhecido como "ideologia de gênero" foram iniciados nos anos 90 por setores da Igreja Católica, preocupados com o avanço dos debates sobre sexualidade, gênero, pautas feministas e direitos reprodutivos. Foi gerado numa espécie de contraofensiva católica, principalmente após a emergência e avanço de movimentos sociais que questionam padrões de regulação sexual, com destaque para o movimento feminista que contesta o papel da mulher na sociedade.

Para os autores, o combate contra a ideologia de gênero visa resistir às mudanças que ocorriam principalmente na América Latina em relação aos direitos sexuais e reprodutivos e alguns avanços sobre esses temas ocorridos na região. No plano internacional, causou grande preocupação dos setores religiosos os caminhos tomados pelas Conferências Mundiais sobre a Mulher, organizadas pela ONU, principalmente a quarta conferência, de 1995 em Pequim, que reconheceu que a desigualdade feminina é uma 
questão estrutural e substituiu em seus documentos o termo "mulher" por gênero (MISKOLCl; CAMPANA, 2017).

Mas a pauta de combate a essa nova perspectiva não ficou restrita somente aos grupos católicos, foi adotada por setores religiosos evangélicos e por outros grupos e atores alinhados com o discurso moralmente conservador principalmente em relação aos direitos sexuais.

Em entrevista concedida à jornalista Andrea Dip (2018), a professora e pesquisadora Jimena Furlani afirma que seus estudos sobre a origem do termo apontam para uma Conferência Episcopal da Igreja Católica, ocorrida em 1998 no Peru, cujo tema era "A ideologia de gênero - seus perigos e alcances."

A pesquisadora identificou dois livros como as principais referências do movimento. O primeiro é o A agenda de gênero de 1996. O livro foi escrito pela ativista pró-vida Dale O'Leary e relata suas experiências como delegada em duas Conferências da ONU que discutiram direitos das mulheres e adotaram a "perspectiva de gênero", inclusive a já mencionada de Pequim.

O outro livro foi escrito pelo advogado e militante antiaborto argentino Jorge Scala, o "Ideologia de gênero: o gênero como ferramenta de poder", cuja primeira edição brasileira é de 2010. O livro afirma que a "ideologia de gênero" é uma ferramenta de poder global, uma ideologia totalitária que pretende criar um novo ser humano, expandir-se e abarcar toda a vida social (SCALA, 2011).

As mobilizações em torno do tema deram força a outros debates e posições conservadores como o debate em relação ao Escola Sem Partido, pois a doutrinação ideológica supostamente realizada por professores abarcaria o debate sobre gênero e sexualidade além das ideias de esquerda (DIP, 2018).

O termo "ideologia de gênero" é marcado por uma imprecisão em sua definição e uso. Ele é usado para se referir a um amplo leque de debates e ideias relacionados à sexualidade, cultura e modo de vida. Pautas que discutam temas como homossexualidade, transexualidade, papéis de gênero e direitos reprodutivos são agrupadas e rotuladas como "ideologia de gênero" por aqueles que visam combatê-la.

No Brasil, o termo ganhou grande relevância e popularidade a partir das discussões sobre o Plano Nacional da Educação (PNE), iniciadas em 2014. Parlamentares católicos e evangélicos se mobilizaram contra a "ideologia de gênero", principalmente com o intuito de impedir que debates sobre gênero sejam realizados no ambiente escolar. A "ideologia de gênero" é frequentemente acusada de contribuir com a destruição da família e visar a doutrinação de crianças (DIP, 2018). 
Segundo seus detratores, a "ideologia de gênero" prega ideias que irão destruir o arranjo familiar tradicional e, visto que a família é o núcleo central da sociedade para esses grupos, acarretará na destruição de toda a sociedade tal qual a conhecemos.

Foi a partir dessa campanha sobre a "ideologia de gênero" que foram retirados termos como "gênero", "orientação sexual", "diversidade sexual", "nome social" e educação sexual de diversos documentos públicos, além de problematizar o uso de palavras como "diversidade", "homofobia" e "identidade de gênero" (DIP, 2018).

As discussões em torno do PNE no Congresso Nacional extrapolaram para outras esferas de governo e entraram na pauta de representantes dos poderes legislativos e executivos e alguns Estados e diversos Municípios. Alguns prefeitos e câmaras de vereadores criaram legislações próprias para impedir o ensino da "ideologia de gênero" em suas escolas. Em reação a esse movimento, certos setores da sociedade começaram a se mobilizar para contrapor essas ações. Uma das formas de mobilização utilizadas é o acionamento do poder judiciário para questionar a validade dessas normas.

É neste contexto que se insere este trabalho. Ele busca analisar os argumentos jurídicos e os dispositivos legais utilizados na tentativa de anular essas normas que proíbem debates relacionados à diversidade sexual e direitos reprodutivos. A principal forma utilizada para provocar o poder judiciário é a interposição de um tipo de ação prevista na Constituição Federal chamada Arguição de Descumprimento de Preceito Fundamental.

\section{A ORDEM CONSTITUCIONAL E ARGUIÇÃO DE DESCUMPRIMENTO DE PRECEITO FUNDAMENTAL}

Uma das possíveis definições de constituição é a de um sistema de normas que regula a forma do Estado, do governo, a disputa e o exercício do poder, desenha a separação de poderes, além de prever direitos e liberdades individuais (PALU, 2001). Esta é uma definição ligada às tradições políticas que inauguraram os Estados liberais ocidentais, aos ideais e experiências provenientes principalmente, da Revolução Francesa e a Independência dos Estados Unidos da América, ambos acontecimentos políticos do final do século XVIII. Grande parte das constituições ocidentais, inclusive a brasileira, possuem normas que desenham o Estado, asseguram a igualdade formal entre os cidadãos e os protegem contra possíveis abusos estatais. 
Com o tempo, novas perspectivas sobre o papel do Estado foram adotadas em diferentes contextos nacionais. Durante o século XIX e começo do $\mathrm{XX}$, diversos países presenciaram movimentos que contestavam condições de vida e trabalho da população bem como as regras de acesso ao poder político. Começa a emergir uma concepção de constituição que prevê normas cujo horizonte axiológico é a ideia de vida digna e de justiça social (MENDES, 2012). Para realizar esses princípios, o Estado é chamado a intervir na ordem social e prestar serviços à comunidade, com vistas a garantir direitos e dignidade. Essa perspectiva decorre de uma longa tradição de demandas e embates sobre direitos ligados à esfera política e social, como os direitos ao sufrágio universal, direitos trabalhistas, modelos de previdência estatais, previsões de ação e prestações ligadas ao fornecimento serviços de educação e saúde, dentre outros.

A Constituição brasileira contém normas vinculadas a essas duas concepções, possui regras que criam e atribuem competências aos principais órgãos do Estado, bem como as regras que regulam a interação e controle entre esses órgãos e com os cidadãos. Ela assume um papel de atendimento de certas necessidades vitais dos membros e de proteção social da comunidade. Por essa razão, dizemos que o Estado desenhado pela Constituição Federal de 1988 é um Estado de Direito (MENDES, 2012).

Além das normas mencionadas acima, a Carta Magna nacional consagra instrumentos especiais que protegem certos direitos, sejam individuais ou coletivos e garantem a defesa da ordem constitucional. Em seu art. 5, inciso XXXV, assegura que apreciação do judiciário contra lesão ou ameaça de lesão a direito.

Entre as ferramentas jurídicas que visam proteger o interesse geral da comunidade estão a ação popular, a ação civil pública, a ação direta de inconstitucionalidade, a ação declaratória de constitucionalidade, a ação direta por omissão e a arguição de descumprimento de preceito fundamental.

A arguição de descumprimento de preceito fundamental é proposta diretamente ao Supremo Tribunal Federal e faz parte dos instrumentos de controle de constitucionalidade das leis, mecanismos jurídicos cujo intuito é garantir a adequação das demais normas à Constituição. Ela objetiva "evitar ou reparar lesão a preceito fundamental, resultante de ato do Poder Público" e também é cabível "quando for relevante o fundamento da controvérsia constitucional sobre lei ou ato normativo federal, estadual ou municipal, incluídos os anteriores à Constituição" (BRASIL, 1999). Apesar de prevista na Constituição em seu art. 102 parágrafo $1^{\circ}$, ela só foi regulada pela Lei 9.882 de 1999.

Através dessa ação é possível determinar a suspensão do ato ao início do processo e pleitear a anulação dele ao final do processo. Os efeitos 
de sua decisão final são erga omnes, valem frente a todos e caráter vinculante, obriga os demais tribunais (PALU, 2001).

Preceitos fundamentais são um conceito amplo, que não é definido pela Constituição ou pela Lei n. 9.882/99. O termo preceito refere-se à ordem, regra ou norma. O termo fundamental, por sua vez, são princípios e regras constitucionais, considerados essenciais à ordem constitucional. Não há consenso doutrinário sobre a definição de preceitos fundamentais, mas certos autores identificam certos direitos previstos no art. 1 como alguns deles. Por exemplo, a soberania nacional, cidadania, dignidade da pessoa humana, valores sociais do trabalho e livre iniciativa, dentre outros direitos previstos e outros dispositivos da Carta Magna. Inclui-se também aqueles preceitos previstos no parágrafo quarto do artigo 60 da Constituição, a forma federativa de Estado; o voto direto, secreto, universal e periódico; a separação dos Poderes; os direitos e garantias individuais (FRANCO FILHO, 2008).

Os legitimados para propor esta espécie de ação são os mesmos legitimados para propor a Ação Direta de Inconstitucionalidade como previsto no art. 103 da Constituição. São eles Presidente da República, a Mesa da Câmara dos Deputados, a Mesa de Assembleia Legislativa ou da Câmara Legislativa do Distrito Federal, o Governador de Estado ou do Distrito Federal, - Procurador-Geral da República, o Conselho Federal da Ordem dos Advogados do Brasil, partido político com representação no Congresso Nacional, confederação sindical ou entidade de classe de âmbito nacional.

conter:

Segundo o art. 3 da Lei 9.882 de 1999, a "petição inicial deverá

\footnotetext{
I - a indicação do preceito fundamental que se considera violado;

II - a indicação do ato questionado;

III - a prova da violação do preceito fundamental;

IV - o pedido, com suas especificações;

V - se for o caso, a comprovação da existência de controvérsia judicial relevante sobre a aplicação do preceito fundamental que se considera violado." (BRASIL, 1999).
}

Como visto acima, em uma ADPF é necessário indicar um preceito fundamental violado e provar sua violação. Na próxima seção serão apresentados os argumentos e dispositivos normativos utilizados para realizar esses intentos e tentar anular as leis que versam sobre a proibição do ensino da "ideologia de gênero".

\section{AS AÇÕES E OS ARGUMENTOS}


Há dez ADPFs que tramitam pelo STF com o intuito de anular leis municipais que proíbem o ensino da "ideologia de gênero", sendo elas:

ADPF 457 de autoria do Procurador-Geral da República (PGR), cuja entrada no STF se deu em 22/05/2017, contra o Prefeito e a Câmara Municipal de Novo Gama-GO, em razão da Lei n. 1516 de 2015 do mesmo município.

ADPF 460 de autoria do Procurador-Geral da República, cuja entrada no STF se deu em 06/06/2017, contra o Prefeito e a Câmara Municipal de Cascavel-PR, em razão do artigo 2 da Lei n. 6496 de 2015 do mesmo município.

ADPF 461 de autoria do Procurador-Geral da República, cuja entrada no STF se deu em 06/06/2017, contra o Prefeito e a Câmara Municipal de Paranaguá-PR em razão do artigo 3, inciso X da Lei n. 3468 de 2015 do mesmo município.

ADPF 462 de autoria do Procurador-Geral da República, cuja entrada no STF se deu em 06/06/2017, contra o Prefeito e a Câmara Municipal de Blumenau-SC, em razão do artigo 10, parágrafo 5 da Lei Complementar n. 994 de 2015 do mesmo município.

ADPF 465 de autoria do Procurador-Geral da República, cuja entrado no STF se deu em 08/06/2017, contra o Prefeito e a Câmara Municipal de Palmas-TO, em razão do artigo 1 da Lei n. 2243 de 2016 do mesmo município.

ADPF 466 de autoria do Procurador-Geral da República, cuja entrada no STF se deu em 08/09/2017, contra o Prefeito e a Câmara Municipal de Tubarão-SC, em razão do artigo 9 da Lei n. 4268 de 2015 do mesmo município.

ADPF 467 de autoria do Procurador-Geral da República, cuja entrada no STF se deu em 08/06/2017, contra a Prefeita e a Câmara Municipal de Ipatinga-MG, em razão dos artigos 2 e 3 da Lei n. 3491 de 2015 do mesmo município.

APDF 522 de autoria do Partido Socialismo e Liberdade (PSOL), cuja entrada no STF se deu em 12/06/2018, contra os Prefeitos e as Câmaras Municipais das cidades de Petrolina-PE e Garanhuns-PE, em razão da Lei $n$. 2985 de 2017 de Petrolina e da Lei n. 4432 de 2017 de Garanhuns.

ADPF 526 de autoria do Partido Comunista do Brasil (PC do B), cuja entrada no STF se deu em 25/06/2018, contra a Câmara Municipal de Foz do Iguaçu-PR, em razão do parágrafo 5 do artigo 162 da Lei Orgânica do Município.

ADPF 600 de autoria da Confederação Nacional dos Trabalhadores Em Educação (CNTE) e da Associação Nacional de Juristas 
Pelos Direitos Humanos de Lésbicas, Gays, Bissexuais, Travestis, Transexuais, Transgêneros e Intersexuais (ANAJUDH LGBTI), cuja entrado no STF se deu em 09/07/2019 contra a Câmara Municipal de Londrina, em razão da Emenda à Lei Orgânica n. 55 de 2018 do mesmo município.

As ações propostas pela PGR são idênticas em conteúdo jurídico e argumentativo, as diferenças apresentadas são pequenas adaptações feitas para se referir aos dispositivos legais questionados. Em verdade, essas ações dão o tom seguido pelas demais. A APDF 522 de autoria do PSOL segue a mesma estrutura argumentativa e repete trechos retirados das ações da PGR. A ADPF 526 e 600 apresentam maiores diferenças, mas ainda têm argumentos e mobilizam dispositivos legais em comum.

A seguir serão apresentados os argumentos utilizados por essas ações com vistas a anular as legislações referidas acima

O primeiro argumento a ser tratado, presente em todas as ações analisadas, é a incompetência dos municípios de legislarem sobre diretrizes e bases educacionais. Segundo o Art. 22, inciso XXIV da Constituição Federal é de competência privativa da União legislar sobre "diretrizes e bases da educação nacional" (BRASIL, 1988). É uma prerrogativa que visa garantir linhas gerais do sistema de ensino nacional e, por isso, é vedado aos municípios estabelecerem suas próprias diretrizes de ensino.

O texto constitucional ainda garante, em seu art. 24, inciso IX, a competência concorrente (exercida simultaneamente) entre União, Estados e Distrito Federal para legislar sobre "educação, cultura, ensino, desporto, ciência, tecnologia, pesquisa, desenvolvimento e inovação" (BRASIL, 1988). Aos municípios resta o disposto nos incisos I e II do art. 30, a garantia de legislar sobre matérias de interesse local e de legislar de maneira "suplementar a legislação federal e a estadual no que couber" (BRASIL, 1988).

Ou seja, segundo esses documentos jurídicos, as leis e normas questionadas foram criadas em desconformidade com a ordem constitucional, pois o ente federado que as criou não tem autorização constitucional de legislar sobre essa matéria, e por isso são dispositivos inconstitucionais.

A União Federal exerce sua competência de legislar sobre o ensino e a educação através das Lei 9.394/96, a Lei de Diretrizes e Bases da Educação Nacional (LDBEN ou LDB). Entre os princípios consagrados pela LDB e relacionados ao debate em pauta, estão os seguintes:

"Art. $3^{\circ} \mathrm{O}$ ensino será ministrado com base nos seguintes princípios:

I - igualdade de condições para o acesso e permanência na escola;

II - liberdade de aprender, ensinar, pesquisar e divulgar a cultura, o pensamento, a arte e o saber; 


\section{III - pluralismo de ideias e de concepções pedagógicas; \\ IV - respeito à liberdade e apreço à tolerância;" (BRASIL, 1988).}

Como pode ser observado, a vedação de se discutir certas ideias ou apresentar certas perspectivas vai de encontro aos princípios estabelecidos na lei, o que mais uma vez aponta quão problemáticas são as tentativas de impedir discussões sobre diversidade e orientação sexual e os debates dos Estudos de Gênero.

O próximo argumento, o da ofensa ao princípio constitucional do devido processo legal, somente não foi apresentado na ADPF 600. Segundo Gilmar Mendes (2012) a garantia do devido processo legal é uma das mais relevantes garantias constitucionais. Ela abarca, por exemplo, o direito ao contraditório e ampla defesa, direito ao juiz natural e direito de não ser processado ou condenado por prova ilícita. $\mathrm{O}$ aspecto substantivo deste direito é a garantia de proteção contra atos arbitrários do Estado, atos não revestidos de razoabilidade, justiça ou proporção.

Como visto anteriormente, a expressão "ideologia de gênero" ou mesmo "perspectiva de gênero" não possuem definições bem delimitadas ou um conteúdo com bases acadêmicas. São expressões usadas de maneira genérica para se referir a debates sobre a diversidade sexual, orientação sexual e sobre papéis de gênero.

As petições da Procuradoria Geral da República, do Partido Socialismo e Liberdade e do Partido Comunista do Brasil argumentam que, ao adotar um conceito tão problemático e discutível como fundamento legislativo, as normas questionadas afrontam o devido processo legal em sua dimensão substantiva, pois não apresentam razoabilidade.

Em termos constitucionais, tal discussão remete ao inciso LIV do art. 5 da Constituição: "ninguém será privado da liberdade ou de seus bens sem o devido processo legal;" (BRASIL, 1988).

Outro argumento mobilizado é o princípio da igualdade, alargado para abarcar o direito à igualdade de gênero. Segundo o caput do art. 5 da Carta Magna, todos são iguais perante a lei, sem distinção de qualquer natureza. Tal norma institui um dos pilares do constitucionalismo, o princípio da igualdade e foi utilizada como argumento em todas as ADPFs analisadas com exceção da ADPF 600. É um princípio também consagrado no plano internacional, como lembram as petições da PGR e do PSOL, em documentos como a Declaração Universal dos Direitos Humanos, a Convenção Americana sobre Direitos Humanos e o Pacto Internacional de Direitos Civis.

A proibição da discussão pedagógica sobre os temas ligados à diversidade sexual viola a igualdade, pois reforça a visão de mundo 
heteronormativa, que prega como "correto", como "normal", por vezes "natural" e, portanto, obrigatória, o padrão de sexualidade heterossexual. O próprio Supremo Tribunal Federal já decidiu em consonância com essa posição ao reconhecer a união estável homoafetiva ao julgar a ação direta de inconstitucionalidade n. 4.277.

Segundo a petição escrita pela PGR, "gênero é categoria que concorre para explicar a diversidade sexual, igualdade de gênero é princípio constitucional que reconhece essa diversidade e proíbe qualquer forma de discriminação. Conforme Pondera Ronald Dworkin, a igualdade impõe que todos sejam tratados com igual respeito e consideração, a exigir assegurar que todas as formas de vida encontrem livre curso na comunidade política e que ninguém seja deixado para trás nem negativamente discriminado por essa condição" (BRASIL, ADPF n. 467, 2017 p. 18).

Na petição da ADPF 526, proposta pelo PC do B, é mencionado, junto à defesa do direito a igualdade, que o inciso IX do art. 5 da CF assegura a "livre a expressão da atividade intelectual, artística, científica e de comunicação, independentemente de censura ou licença", bem como o parágrafo 2 do art. 220 do mesmo diploma que estabelece a vedação de "toda e qualquer censura de natureza política, ideológica e artística” (BRASIL, 1988).

Os autores desse documento jurídico argumentam que a escola é um dos principais espaços de socialização das crianças, espaço de encontro de culturas, compartilhamento de valores e de promoção da cidadania. Por essas razões, a escola é um espaço que deve promover o respeito às diferenças, principalmente quando se trata do respeito a grupos marginalizados e vítimas de violência como a população LGBT (Lésbicas, Gays, Bissexuais e Transexuais). Essa população encontra diversas barreiras na sociedade, inclusivo no núcleo familiar e no ambiente escolar. Logo, seria necessário que a escola fosse um ambiente democrático e inclusivo, que ensino o respeito, tolerância e promova a igualdade de gênero.

A ADPF 600, por sua vez, trabalha os incisos IV e IX do art. 5 e 0 parágrafo 3 do art. 220, sob o argumento da violação ao direito de liberdade de expressão imposta pela proibição das discussões sobre "ideologia de gênero. Outro argumento utilizado somente nesta petição é o da violação ao dever estatal de combater as desigualdades e marginalização, promover o acesso à cultura e à educação, previstos nos incisos V e X do art. 23 da CF.

O direito à educação plural, inclusiva, democrática, à liberdade de cátedra estão previstos nos artigos 205 e 206 da Constituição Federal.

O primeiro deles afirma que: "a educação, direito de todos e dever do Estado e da família, será promovida e incentivada com a colaboração da 
sociedade, visando ao pleno desenvolvimento da pessoa, seu preparo para o exercício da cidadania e sua qualificação para o trabalho" (BRASIL, 1988).

Já o segundo artigo mencionado, estabelece os seguintes certos princípios para o ensino nacional, dos quais destacam-se: a igualdade de condições para o acesso e permanência na escola, a liberdade de aprender, ensinar, pesquisar e divulgar o pensamento, a arte e o saber, e o pluralismo de ideias e de concepções pedagógicas (BRASIL, 1988).

Ou seja, segundo a carta constitucional, a educação visa formar cidadãos, garantir o respeito e o convívio numa sociedade diversa e plural. A preocupação contra a "ideologia de gênero" parte principalmente de setores religiosos ou ligados ao conservadorismo moral em relação a sexualidade. Esses grupos argumentam, principalmente, que o ensino sobre sexualidade seja relegado às famílias. Contudo, o ensino e debate sobre a sexualidade está inserido nas discussões de saúde e reprodução humana. Como lembra a petição da PGR "educação democrática permite que o Estado defina os conteúdos dos cursos de formação e objetivos do ensino, em alguma medida até de forma independente dos pais, sem que isso signifique redução da importância crucial que a família possui no processo de formação de crianças e adolescentes (BRASIL, ADPF n. 467, 2017 p. 22).

A ADPF 600 proposta pela CNTE e pela ANAJUDH LGBTI argumenta no mesmo sentido e com os mesmos dispositivos na seção intitulada Violação do princípio da pluralidade de cátedra e do pluralismo de ideias e concepções pedagógicas. Lembram que a liberdade de cátedra prevista no art. 206 garante a autonomia do docente frente à família e ao Estado. Tal fato não implica na liberdade plena do professor, pois existem normativas como a Lei de Diretrizes e Bases da Educação, a Base Nacional Curricular Comum e os Planos de Educação para regulamentar o conteúdo ensinado e existem mecanismos de responsabilização de abusos.

A mesma petição lembra que uma educação plural tem como pressupostos o dissenso, o conflito e o diálogo. Ela dá meios aos indivíduos de serem livres para autodeterminar.

Por fim, todas as ações argumentam que tais leis ferem a laicidade do Estado, principalmente pois pretendem impor uma visão moral de mundo associada à religião cristã. Apontam como esse repúdio às discussões sobre sexualidade e gênero são uma das principais pautas de grupos conservadores religiosas.

Todo cidadão tem a liberdade de professar e escolher a religião de sua escolha e não ser obrigado a seguir os princípios ligados a outra religião, como pretender diversos militantes cristãos. 


\section{CONSIDERAÇÕES FINAIS}

Ao longo deste trabalho foram percorridas três etapas principais: a apresentação da discussão em torno dos debates de gênero na esfera pública e seu reflexo nos debates sobre as bases educacionais e o currículo escolar; as principais características da Arguição de Descumprimento de Preceito Fundamental e sua relação com a ordem constitucional; os argumentos mobilizados nas ações analisadas cujo intuito é defender a inclusão dos debates sobre gênero e diversidade sexual nas bases curriculares.

A partir do percurso percorrido neste trabalho foi possível verificar quais e como foram empregados foram os argumentos e dispositivos legais mobilizados nestas ações, contribuindo para a compreensão de como esses temas se articulam com os direitos humanos e a ordem constitucional brasileira.

Princípios e direitos como a igualdade, liberdade de expressão, ao ensino inclusivo e democrático e laicidade podem ser mobilizados para alcançar esses temas e mudar a compreensão e interpretação deles enquanto aspectos da vida humana que devem ser respeitados e respaldados por uma sociedade realmente democrática e pelo Estado de Direito.

\section{REFERÊNCIAS}

BRASIL. Constituição da República Federativa do Brasil de 1988. Brasília, DF: Presidência da República. Disponível em:

http://www.planalto.gov.br/ccivil_03/constituicao/constituicaocompilado.htm. Acesso em: 05 set. 2019.

BRASIL. Lei n. 9.394, de 20 de dezembro de 1996. Brasília, DF: Presidência da República. Disponível em: http://www.planalto.gov.br/ccivil_03/LEIS/L9394.htm. Acesso em: 05 set. 2019.

BRASIL. Lei n. 9.882, de 02 de dezembro de 1999. Brasília, DF: Presidência da República. Disponível em: http://www.planalto.gov.br/ccivil_03/leis/19882.htm. Acesso em: 05 set. 2019.

BRASIL. Supremo Tribunal Federal. Arguição de Descumprimento de Preceito Fundamental $n$. 457. Autor: Procurador-Geral da República. Brasília, proposta em: 22/05/2017. Disponível em:

http://www.stf.jus.br/portal/geral/verPdfPaginado.asp?id=12941920\&tipo=TP\&descrica $\mathrm{o}=\mathrm{ADPF} \% 2 \mathrm{~F} 457$

BRASIL, Supremo Tribunal Federal. Arguição de Descumprimento de Preceito Fundamental $n$. 460. Autor: Procurador-Geral da República. Brasília, proposta em: 06/06/2017. Disponível em: 
http://www.stf.jus.br/portal/geral/verPdfPaginado.asp? $\mathrm{id}=13017641 \&$ tipo=TP\&descrica $\mathrm{o}=\mathrm{ADPF} \% 2 \mathrm{~F} 460$

BRASIL, Supremo Tribunal Federal. Arguição de Descumprimento de Preceito Fundamental n. 461. Autor: Procurador-Geral da República. Brasília, proposta em: 06/06/2017. Disponível em:

http://www.stf.jus.br/portal/geral/verPdfPaginado.asp?id=13017648\&tipo=TP\&descrica o=ADPF\%2F461. Acesso em: 05 set. 2019

BRASIL, Supremo Tribunal Federal. Arguição de Descumprimento de Preceito Fundamental n. 462. Autor: Procurador-Geral da República. Brasília, proposta em: 06/06/2017. Disponível em:

http://www.stf.jus.br/portal/geral/verPdfPaginado.asp?id=13017655\&tipo=TP\&descrica o=ADPF\%2F462. Acesso em: 05 set. 2019

BRASIL, Supremo Tribunal Federal. Arguição de Descumprimento de Preceito Fundamental n. 465. Autor: Procurador-Geral da República. Brasília, proposta em" 08/06/2017. Disponível em:

http://www.stf.jus.br/portal/geral/verPdfPaginado.asp? $\mathrm{id}=13028588 \&$ tipo=TP\&descrica o=ADPF\%2F465. Acesso em: 05 set. 2019

BRASIL, Supremo Tribunal Federal. Arguição de Descumprimento de Preceito Fundamental n. 466. Autor: Procurador-Geral da República. Brasília, proposta em: 08/09/2017. Disponível em:

http://www.stf.jus.br/portal/geral/verPdfPaginado.asp?id=13028595\&tipo=TP\&descrica o=ADPF\%2F466. Acesso em: 05 set. 2019

BRASIL, Supremo Tribunal Federal. Arguição de Descumprimento de Preceito Fundamental n. 467. Autor: Procurador-Geral da República. Brasília, proposta em: 08/06/2017. Disponível em:

http://www.stf.jus.br/portal/geral/verPdfPaginado.asp?id=13028586\&tipo=TP\&descrica o=ADPF\%2F467. Acesso em: 05 set. 2019

BRASIL, Supremo Tribunal Federal. Arguição de Descumprimento de Preceito Fundamental n. 522. Autor: Partido Socialismo e Liberdade. Brasília, proposta em: 12/06/2018. Disponível em:

http://redir.stf.jus.br/estfvisualizadorpub/jsp/consultarprocessoeletronico/ConsultarProc essoEletronico.jsf?seqobjetoincidente=5485351. Acesso em: 05 set. 2019

BRASIL, Supremo Tribunal Federal. Arguição de Descumprimento de Preceito Fundamental n. 526. Autor: Partido Comunista do Brasil. Brasília, proposta em" 25/06/2018. Disponível em:

http://redir.stf.jus.br/estfvisualizadorpub/jsp/consultarprocessoeletronico/ConsultarProc essoEletronico.jsf?seqobjetoincidente=5496114. Acesso em: 05 set. 2019

BRASIL. Supremo Tribunal Federal. Arguição de Descumprimento de Preceito Fundamental n. 600. Autor: Confederação Nacional dos Trabalhadores Em Educação e Associação Nacional de Juristas Pelos Direitos Humanos de Lésbicas, Gays, Bissexuais, Travestis, Transexuais, Transgêneros e Intersexuais. Brasília, proposta em: 09/07/2019. Disponível em: 
http://redir.stf.jus.br/estfvisualizadorpub/jsp/consultarprocessoeletronico/ConsultarProc essoEletronico.jsf?seqobjetoincidente=5496114. Acesso em: 05 set. 2019

DIP, Andrea. Em nome de quem?: a bancada evangélica e seu projeto de poder. 1. ed. Rio de Janeiro: Civilização Brasileira, 2018.

FRANCO FILHO, Alberto de Magalhães. O Significado e Alcance da Expressão "Preceito Fundamental no Âmbito da Arguição de Descumprimento de Preceito Fundamental. Revista Eletrônica do Curso de Direito da UFSM. Santa Maria, vol 3. n. 3, 2008. Disponível em:

https://periodicos.ufsm.br/revistadireito/article/view/7023/4241. Acesso: 05 set. 2019.

MENDES, Gilmar. Curso de direito constitucional. 7. ed. São Paulo: Saraiva, 2012.

MISKOLCI, Richard. Estranhando as Ciências Sociais: Notas introdutórias sobre Teoria Queer. Revista Florestan Fernandes. São Carlos. ano 01. a. 02, 2014.

MISKOLCI, Richard; CAMPANA, Maximiliano. "Ideologia de gênero": notas para a genealogia de um pânico moral contemporâneo. Soc. estado. [online]. vol.32, n.3, 2017. Disponível em: http://www.scielo.br/pdf/se/v32n3/0102-6992se-32-03-725.pdf. Acesso em: 05 set. 2019.

OKA, Mateus and LAURENTI, Carolina. Entre sexo e gênero: um estudo bibliográfico-exploratório das ciências da saúde. Saúde soc.[online]. vol.27, n.1, 2018. Disponível em:

http://www.scielo.br/scielo.php?script=sci_arttext\&pid=S0104$12902018000100238 \&$ Ing=en\&nrm=iso\&tlng=pt. Acesso em: 05 set. 2019.

PALU, Oswaldo Luiz. Controle de constitucionalidade: conceitos, sistemas e efeitos. 2. Ed. São Paulo: Editora Revista dos Tribunais, 2001.

SCALA, Jorge. Ideologia de Gênero - o neototalitarismo e a morte da família. São Paulo: Katecheses e Artpress, 2011. 


\title{
PERCEPÇÕES DE ALUNOS UNIVERSITÁRIOS SOBRE DIVERSIDADE DE GÊNERO E INTOLERÂNCIA DENTRO DO CAMPUS
}

\author{
SILVA, Renan Antônio da \\ Docente - Unitins
}

\section{INTRODUÇÃO}

Sabe-se que no cenário contemporâneo é um desafio discutir um tema tão complexo como a diversidade de gênero. A implicação de que gênero é uma norma requer muitas elaborações, pois uma norma não é o mesmo que uma regra, ou lei. Uma norma atua no campo de práticas sociais sob o padrão trivial implícito da normalização. (BUTLER, 2014).

Silva (2018) afirma que no contexto atual não cabe mais o binarismo de gênero, superado por uma variedade de signos culturais que esboroam o "maniqueísmo de gênero. (2017, p. 153).

A universidade é o lugar do conhecimento e por isso, na maioria das vezes é lá que os grandes debates acontecem, no caso deste estudo, acredita-se, ainda que a convivência mais próxima da diversidade de gênero que se a vizinha nas vidas de estudantes jovens pode trazer uma abertura ao diálogo e uma maior compreensão na eliminação dessa dualidade homemmulher. O campus universitário deve ser um espaço inclusivo e seguro em todas as nuances da inclusão, pois em seu interior as identidades afloram, seja no processo de maturidade, sejam no processo de formação da identidade de sua formação profissional.

Pouco se sabe sobre a percepção de estudantes heterossexuais sobre a população LGBTT, sobre como isso influencia no clima do campus o que inclui o clima nas salas de aula (WOODFORD et al, 2012; KANE, 2013).

Ao conhecer o que os estudantes pensam e veem no campus pode-se ter uma ideia de como proceder para se conseguir maior acolhimento dessa população e a eliminação de preconceito e de qualquer tipo de violência contra esses cidadãos. São objetivos deste breve estudo: descrever como os estudantes universitários percebem a diversidade de gênero no campus e 0 tratamento dispensado pelos colegas a essas pessoas.

Parte-se da hipótese de que, no ambiente universitário, existe um maior acolhimento da população LGBTT, uma vez que vários cursos discutem abertamente a inserção social dessa população e há a presença do diálogo nas universidades o que é fundamental para uma política de maior acolhimento para essa população. 
Segundo a Organização Mundial de Saúde (2018): "gênero referese aos conceitos sociais das funções, comportamentos, atividades e atributos que cada sociedade considera apropriados para homens e mulheres, inclusive podem gerar desigualdades ou seja, diferenças entre homens e mulheres que favorecem sistematicamente a um dos grupos. Por sua vez, essas desigualdades podem criar iniquidades entre homens e mulheres tanto com respeito a seu estado de saúde quanto a seu acesso aos cuidados de saúde." O gênero estando incorporado num ator social específico passa a ser uma norma (BUTLER, 2014).

Essa norma não é estática, ela é historicamente determinada, e nesse caso, quando não há um consenso com esse papel social a ser desempenhado emerge a estigmatização, a exclusão social e a discriminação (OMS, 2018). Gênero não é precisamente o que a pessoa é ou tem. É aquilo que a produção e a normalização do masculino e do feminino se revelam junto com as nuances físicas (hormonais, cromossômicas) e comportamentais (performáticas) que cada gênero assume (BUTLER, 2014).

Há muito pouco acerca das práticas dos estudantes universitários com a diversidade de gêneros e pouco ainda se percebe o comprometimento dos recursos humanos do campus em criar uma cultura para a diversidade, aberta com discussões em salas de aula, comunidades que abordem as minorias e programas que efetivamente sejam engajados na inclusão. (POYNTER e WASHINGTON, 2005).

Muitas pesquisas acerca do comportamento (in)tolerante com a população LGBTT trazem variáveis como: tolerância/julgamentos negativos, moralidade, estereótipos que indicam nuances de homofobia, outras variáveis também vêm sendo incluídas, assim como religião, afiliação política, nível de formação acadêmica, orientação sexual entre outros pois podem balizar esforços para a criação de programas de acolhimento das diversidades (HOLLAND et al, 2013).

De acordo com Camargo e Sampaio Neto (2017), a identidade deve ser construída pelo ser humano, ele mesmo, embora haja as influências que se entranham, cada uma delas disputa com o sujeito, seu modo de ser e de agir, com seus, desejos e suas práticas sexuais, percebendo que eles podem ser modificados. As construções sobre as noções de macho e fêmea são científicas e conduzem à manutenção da espécie dos seres vivos, já a noção de masculino e feminino é construída de acordo com uma dada cultura e transcende a relação binária macho-fêmea. (BUTLER, 2014).

\section{MATERIAIS E MÉTODO}


Trata-se de um estudo descritivo, de abordagem qualitativa, de corte transversal. Os dados foram coletados de Fevereiro a Março de 2019 entre universitários de diferentes cidades do estado de São Paulo. Os materiais utilizados foram um questionário baseado em Madureira (2007) que foi disponibilizado no Google Forms ${ }^{\circledR}$ e foi enviado para estudantes que fazem parte da rede do pesquisador. Cada estudante foi convidado a participar e em seguida convidar mais um colega de sua universidade ou de outra localidade, desde que fosse estudante universitário e que tivesse mais de 18 anos. Tratase de uma pesquisa de opinião cujo convite foi feito pela rede social WhatsApp ${ }^{\circledR}$, já que o tipo de coleta de dados oferece um link que se abre e o participante pode responder usando o aparelho celular. Ao abrir o link, o estudante se deparava com o Termo de Consentimento Livre e Esclarecido (TCLE), em aceitando participar, o estudante abria o questionário e o aluno era livre para ir até o final ou interromper se assim o desejasse, porém todos os 61 estudantes que aceitaram participar, responderam ao questionário todo. Os dados coletados foram tabulados em planilha Excel e analisados quantitativamente quando assim fosse necessário e realizou-se uma Análise de Conteúdo com os dados qualitativos (MURAGURI, 2016).

O projeto foi aprovado pelo comitê de ética em pesquisa com seres humanos da Universidade de Mogi das Cruzes, sob número: 3.222.984

\section{RESULTADOS E DISCUSSÕES}

Foram participantes 61 estudantes universitários, sendo 35 que se identificaram como sendo do gênero feminino, 25 do masculino e um como outro. A média de idade foi de 22,28 $\pm 6,03$ anos e 73,9\% residem no Alto Tietê; $18 \%$ na cidade de São Paulo; 3,3\% no Vale do Paraíba e Interior de São Paulo, Litoral Sul e ABC com 1,6\%.

Quanto à religião obteve-se o seguinte resultado: Católica 27,9\%; Agnóstico - 3,3\%; Espiritismo - 8,2\%; Evangélica -9,8\%; Cristã - 8,2\%; Nenhuma - 13,1\%; Em branco - 24,6\%; Erros de preenchimento - 4,9\%. A religião fez parte do questionário, era uma questão facultativa. Entendeu-se que, muitas vezes a religião poderia ser um obstáculo a ações de tolerância à população em estudo. No Brasil, atualmente, alguns segmentos religiosos rejeitam a homossexualidade, pois entendem como norma a heterossexualidade (NATIVIDADE \& OLIVEIRA, 2009).

Quando se perguntou se os estudantes haviam presenciado, no campus, alguma situação de discriminação ou constrangimento diante de um comportamento não adequado ao gênero $82 \%$ disseram que não e $18 \%$ que sim. As atitudes foram classificadas por categorias (tab.1) 
Tabela 1 - Exemplo de situação de discriminação ou constrangimento

Variáveis Frequência

\begin{tabular}{r|l|l|}
\hline Brincadeiras e piadas & 6 & 37,5 \\
\hline Uso de termos ofensivos & 5 & 31,2 \\
\hline Hostilidade em esportes & 2 & 12,5 \\
\hline Comentários sobre trajes & 3 & 18,8 \\
\hline Totais & $16^{*}$ & 100
\end{tabular}

Alguns estudos, exemplifica Ellis (2008) exploram o clima do campus, e mais frequentemente tendem a focar em registros de homofobia e percepção do clima homofóbico, com ênfase nos que praticam esse tipo de violência e o contexto dentro do qual ocorrem. Para entender esse clima, buscou-se entender como esses alunos exemplificavam que tipo de discriminação ou constrangimento existia:

\section{- Brincadeiras}

- Zoação por gostar de algo que culturalmente não é tão aceito. Como por exemplo, achar bonito alguém do mesmo sexo.

- Sempre tem aquelas piadinhas que "aparentemente" são inofensivas

\section{- Ofensa verbal}

- Fala algo, e o restante chamar de viado, ou associa alguém com a situação que foi exposta, insinuando zoando que seja homossexual

- Quando um colega que tem um jeito mole de falar disse aos colegas não gostar de futebol, automaticamente responderam que não era de se esperar isso dele, e que dele esperava-se que brincasse de boneca.

- Um aluno na minha sala frequentemente era alvo de piadas sobre homossexuais por ser um menino tímido e "diferente" aos olhos dos demais.

- Ah, piadas comuns no dia a dia, tais como ala que viadinhio ou bicha, essas coisas.

- Inferiorização. Falar que é coisa de viado, ou que não aguentaria fazer determinada ação por ser afeminado.

- Um aluno da minha sala tinha voz mais suave que os outros meninos, sentava-se com uma boa postura e acabou sendo 
alvo de gozação, recebeu apelido e quando os meninos o chamavam, afinavam a voz.

\section{- Hostilidade na prática de esportes}

- Em uma aula de prática de Educação Física ouvi comentários em tom de sarcasmo sobre um colega que usava uma calça "legging" e por ser feminina ouvi alguns comentários que apesar de não serem ditos diretamente contra a pessoa eram pejorativos contra ele.

\section{- Comentários sobre trajes}

- Zombaria por motivos de vestimentas

- Casos que interferem nas vestimentas e das modalidades que tem afinidade

Assim, observa-se que há um índice maior nas brincadeiras e piadas $37,5 \%$, seguido de uso de termos ofensivos, que expõe por meio de situações aparentemente não hostis, mas que humilham. O resultado descrito, destoa dos resultados da Pesquisa Nacional sobre o ambiente educacional no Brasil (2016) a qual aponta os maiores níveis de agressão verbal tiveram como alvo a orientação sexual ou identidade de gênero dos estudantes LGBT.

Para Poynter e Washington (2005) a linguagem é um grande desafio na compreensão e no engajamento das múltiplas identidades: assim palavras ofensivas e zombarias são consideradas agressões verbais.

Silva (2018) entende que a violência está presente no pensamento social brasileiro uma vez que os longos séculos humilhações e constrangimentos durante o tempo do Brasil colônia acabaram por exaltar figuras históricas violentas, isso se reflete até os nossos dias, nas altas taxas de criminalidade inclusive contra a população trans, afirma o autor.

Talvez não só no Brasil, mas em outros países essa realidade existe, Woodford et al. (2012) encontraram, entre estudantes universitários, resultados que apontam que a minoria sexual e os transgêneros experimentam discriminação e opressão mesmo vivendo num tempo de compreensão e acolhimento mais expansivo. O resultado disso, afirmam os autores, vem incentivando as universidades a desenvolverem iniciativas institucionais para a melhoria do clima dentro do campus.

As universidades, que atraem para si a tarefa de criar conhecimento, de ser o lugar onde a inovação desponta deveria ser o primeiro patamar para que se pudesse ressignificar e construir valores como a ética, o respeito e atitudes que combaterão a discriminação contra homossexuais, negros, indígenas, meninas e meninos tímidos ou discretos, mulheres lésbicas, transexuais, bissexuais e outras formas de orientação sexual e latente, 
manifestada por meio de piadas, brincadeiras de mau gosto, olhares, gestos e atitudes preconceituosas.

Diariamente acontecem situações desagradáveis em sala de aula contra alunos e alunas homossexuais, com anedotas machistas, palavras de baixo calão, estereótipos ofensivos, deboches e atitudes aparentemente "inofensivas", mas que servem como estigma (ELIAS E SCOTSON, 2000).

Tabela 2 - Opinião dos respondentes sobre homossexualidade

\begin{tabular}{c|c|c|} 
Variáveis & Participantes & $\%$ \\
\hline É genética & 22 & 36,1 \\
\hline É aprendida & 1 & 1,6 \\
\hline É uma escolha & 8 & 13,1 \\
\hline É genética e aprendida & 26 & 42,6 \\
\hline Não sei & 3 & 5 \\
\hline Outra resposta & 1 & 1,6 \\
\hline Totais & 61 & 100
\end{tabular}

Nota-se que em relação à homossexualidade $42,6 \%$ entendem como sendo genética e aprendida e $36,1 \%$ diz ser genética, a partir disto Oka e Laurenti (2018), relatam que os conceitos de sexo e de gênero surgem como termos que se referem a dois campos opostos em disputa: de um lado, as características estritamente bioquímicas e fisiológicas estudadas pelas biociências e, de outro, a dimensão subjetiva e cultural do que é ser mulher ou ser homem, sendo campo de análise das ciências humanas.

Quando se constata que padrões comportamentais considerados masculinos ou femininos não são universais, mas contingentes culturalmente, a estratégia política e epistemológica adotada caminha para a remoção da rigidez da natureza biológica e sua substituição pelo domínio cultural, flexível e simbólico. Ironicamente, essa própria noção enrijecida da biologia é o que dá base à construção cultural do "gênero", tornando o "sexo" inquestionável. (OKA e LAURENTI, 2018 p.248)

No caso do estudante que respondeu outra, assim se expressou:

- É uma opção de vida uma pessoa baseada na forma em que ela se sente bem com suas próprias escolhas sem levar em conta o padrão imposto pela sociedade. 
$\mathrm{Na}$ questão $8 \mathrm{em}$ que se pergunta qual seria o posicionamento perante uma situação em que presenciasse a discussão de um grupo de colegas sobre um casal homossexual de uma novela na TV obteve-se o seguinte resultado.

Figura 1 - Posicionamento face a discussão sobre casal homossexual na mídia.

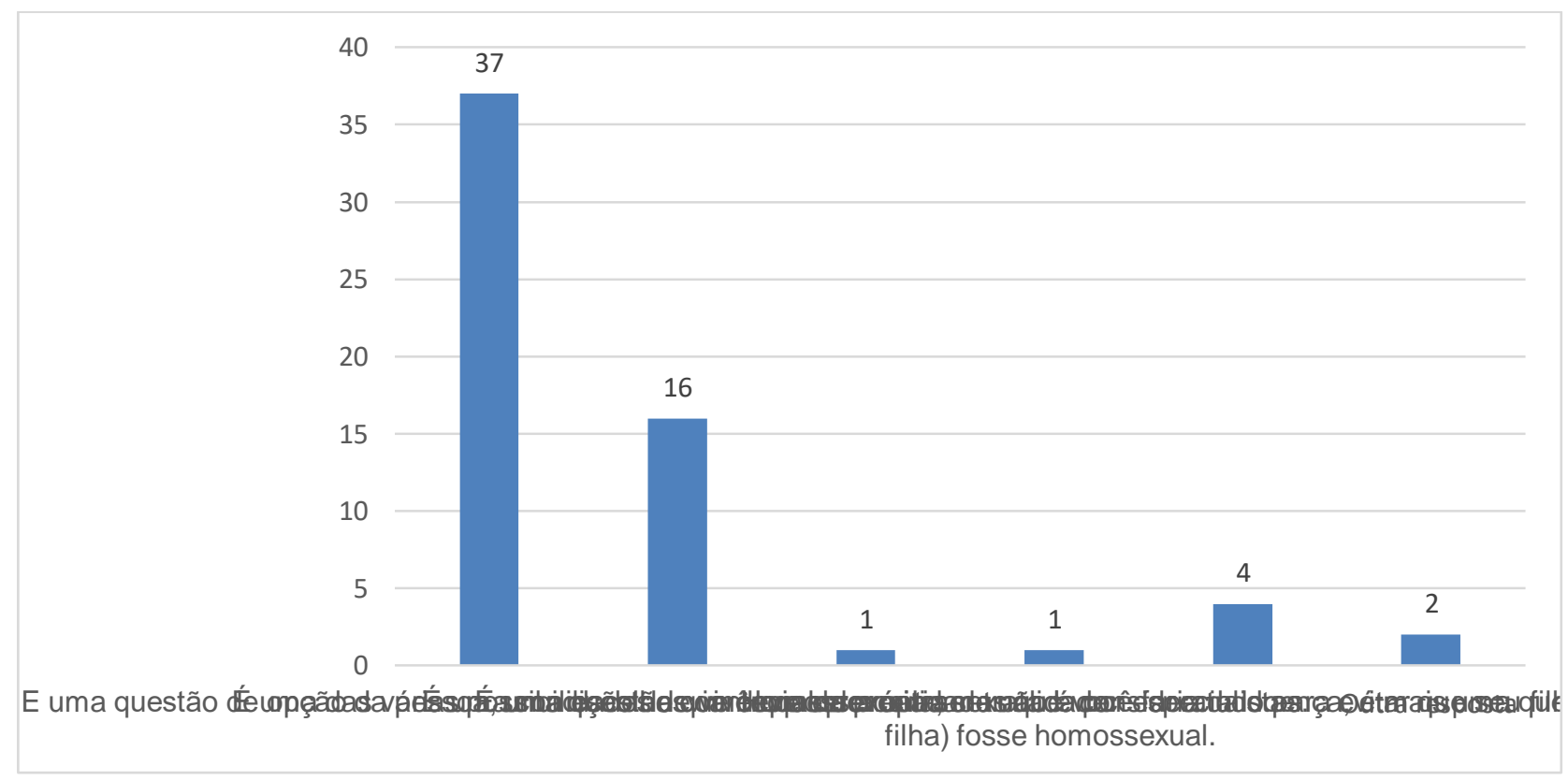

Percebemos que nesta questão 0 posicionamento dos entrevistados, em sua maioria, é uma questão de opção da pessoa, uma escolha como qualquer outra com 37 respostas, seguida da É uma das várias possibilidades de vivência da própria sexualidade, com 16.

Com relação à exposição da representação de travestis e transexuais na mídia Silva e Poloni (2018) argumentam que a essa população é a que mais sofre com as representações generalistas e caricatas na mídia, principalmente nas novelas, apontando, inclusive que muitos personagens são tratados com intuito de provocar o riso.

pronunciaram

No caso dos estudantes que responderam outra, assim se

- Acho que as relações tanto hétero como homo não se resumem ao sexo, outros fatores como interesses em comum, maneiras de comportar diante da vida, com os outros, são também questões que devem ser consideradas.

- Não me importo com a opção sexual das pessoas, mas acho que não deveria ser retratado este assunto na TV 
Como a vida oferece escolhas e possibilidades, observa-se que os participantes, em sua grande maioria acreditam ser uma opção. Assim, esse olhar demonstra que a homossexualidade está presente na história desses alunos sem uma visão muito conservadora. $O$ que se imagina aqui neste breve estudo é que na medida em que os alunos foram sendo convidados e convidando colegas, houve um certo direcionamento para que quem fosse mais flexível ao tema respondesse às questões, pelo menos é o que se supõe. Para Kane (2013) questões de gênero e homofobia é menor em adultos jovens.

\section{Tabela 3 - Existência de trabalho de conscientização da questão sobre população LGBTT na universidade}

\begin{tabular}{c|c|c|} 
Variáveis & Participantes & $\%$ \\
\hline Sim & 3 & 4,9 \\
\hline Não & 24 & 39,4 \\
\hline Talvez & 26 & 42,6 \\
\hline Não sei & 8 & 13,1 \\
\hline Totais & 61 & 100 \\
\hline
\end{tabular}

Nesta questão observamos que as pessoas não sabem se há conscientização sobre a população LGBTT, por isso é necessário criar mecanismos para despertar alunos e professores sobre a importância deste assunto junto aos alunos nas universidades.

O gênero é resultado de diferentes aprendizagens que o indivíduo acumula, a partir de suas relações interpessoais, ao longo de suas experiências de vida dentro de um contexto histórico, político e social. É marca que o indivíduo carrega indelevelmente, de tal forma que se torna mais fácil modificar a configuração anatômica (sexo) de alguém do que sua configuração psicológica (gênero). (PRAUN, 2011 p.64)

Programas educacionais que despertem a consciência para o respeito são importantes para a melhoria das relações nas universidades baseados no diálogo, que possam sugerir novas atitudes e 0 respeito a opiniões diversas para que haja uma mudança (WOODFORD et al., 2012). Políticas contra a discriminação dentro do campus protegem os grupos de estudantes que se reconhecem como minorias sexuais (KANE, 2014). 
Quando convidados a acrescentar alguma coisa, alguns estudantes assim se pronunciaram:

- Todos devem ser respeitados independente da opção sexual (masculino, $2^{\circ}$ anos, Ed. Física, nenhuma religião)

- Acho que quanto mais tratarmos destas questões dentro das salas de aula, mais fácil será lidar, principalmente para aqueles que são muito conservadores. (Feminino, 43 anos, Educação, nenhuma religião)

- Por mim cada indivíduo tem direito de escolha, seja ela qual, sexual, religiosa, não importa qual, mas o caráter deste individuo que importa. (Masculino, 25 anos, Ed. Física, Espírita).

- O respeito e educação deve ser incentivado não por grupos e sim entre a população geral. Enquanto grupos (héteros, homossexuais, negros, brancos, azuis...) existirem, não haverá conquistas significativas de avanço social. (Masculino, 26 anos, Ciências Contábeis, Cristão)

- Acredito que mesmo quem não concorda e deseja se expressar deve ter o direito de o fazer, se alguém for censurado a liberdade do todo será comprometida. (Masculino, 20 anos, Direito, Agnóstico)

Holland et al (2013) apontaram achados interessantes, pois seus resultados sugeriram que estudantes com maior nível de tolerância com a comunidade LGBTT são os que estão nos anos finais e matriculados nos cursos de artes e ciências.

A julgar por esses resultados, percebe-se que se assemelham aos de Ellis (2008), pois sugerem que a homofobia no campus é significante, mas não um problema esmagador.

\section{CONCLUSÕES}

Os objetivos deste estudo eram descrever como os estudantes universitários percebem a diversidade de gênero no campus e o tratamento dispensado pelos colegas a essas pessoas. Entende-se que esses objetivos foram atingidos pois os participantes demonstraram haver tolerância e respeito com a população LGBTT.

Os estudantes que participaram desta pesquisa se encontram em cidades com universidades públicas e particulares com grande número de alunos, o que pode ser uma mostra favorável, embora o número de participantes pode ser um elemento limitador de conclusões mais abrangentes. Outros resultados podem ser obtidos em cidades mais distantes dos grandes centros, ou em universidades de diferentes regiões do país.

Em virtude das opiniões dos alunos e seus posicionamentos, confirmou-se a hipótese de que no ambiente universitário existe um maior acolhimento da população LGBTT, ou porque são pessoas com mais acesso à 
informação e ao conhecimento, ou ainda porque muitos cursos discutem abertamente a inserção social dessa população. Esses resultados também fazem com que se acredite que a presença do diálogo nas universidades é fundamental para uma política de maior acolhimento para essa população e a todos os diferentes de modo geral. A religião não interfere no respeito a outras identidades de gênero, nem as idades e os cursos que os estudantes frequentam.

Os resultados também demonstraram que alguns participantes apontaram a existência de comentários e julgamentos que podem conduzir à violência verbal e à humilhação. Entende-se que o problema da homofobia no campus é ainda pequeno, mas que algumas precauções podem ser tomadas como a sensibilização em salas de aula, nos currículos ou mesmo em programas inclusivos.

\section{REFERÊNCIAS}

ASSOCIAÇÃO BRASILEIRA DE LÉSBICAS, GAYS, BISSEXUAIS, TRAVESTIS E TRANSEXUAIS. Secretaria de Educação. Pesquisa Nacional sobre o Ambiente Educacional no Brasil 2015: as experiências de adolescentes e jovens lésbicas, gays, bissexuais, travestis e transexuais em nossos ambientes educacionais. Curitiba: ABGLT, 2016.

BUTLER, Judith. Regulações de Gênero. Cadernos Pagu (42), jan-jun:249274, de $2014 . \quad$ Disponível em: https://periodicos.sbu.unicamp.br/ojs/index.php/cadpagu/article/view/8645122. Acessado em: 22.04.2019.

CAMARGO, Shelley A.P.; SAMPAIO NETO, Luiz F. Sexualidade e gênero. Revista Faculdade Ciências Médicas Sorocaba;19(4):165-6, 2017. Disponível em: https://revistas.pucsp.br/RFCMS/article/viewFile/35351/pdf. Acessado em: 22.04.2019.

ELIAS, N.; SCOTSON, J. L. Os estabelecidos e os outsiders: sociologia das relações de poder a partir de uma pequena comunidade. Rio de Janeiro: Jorge Zahar, 2000

ELLIS, Sonja. Diversity and inclusivity at university: a survey of the experiences of lesbian, gay, bisexual and trans (LGBT) students in UK. Higher Education. Vol. 57. No. 6. Jun. 2009. DOI: https://doi.org/10.1007/s10734-008-9172-y. 
HOLLAND, Laurel, MATTHEWS, Todd L., SCHOTT, Melinda R. "That's So Gay!" Exploring College Students' Attitudes Toward the LGBT Population, Journal of Homosexuality, 60:4, 575-595, 2013. DOI: 10.1080/00918369.2013.760321.

KANE, Melinda D. finding" safe" campuses: predicting the [resence pf LGBTstudent groups at Noth Carolina colleges and universities. Journal of Homosexuality, 60:828-852. 2013. DOI: 10.1080/00918369.2013.774837.

MADUREIRA, Ana Flávia A. Gênero, Sexualidade e diversidade na escola: a construção de uma cultura democrática. Tese de doutorado. Instituto de Psicologia. Universidade de Brasília. 2007. Disponível em: http://repositorio.unb.br/bitstream/10482/1610/1/Tese AnaFlaviaAmaralMadurei ra.pdf. Acessado em 22.04.2019.

MURAGURI, Michael. Qualitative research methods for public policy. LAP LAMBERT: Saarbruchen, Germany. 2016.

NATIVIDADE, Marcelo; OLIVEIRA, Leandro de. Sexualidades ameaçadoras: religião e homofobia(s) em discursos evangélicos conservadores. Sexualidad, Salud y Sociedad. Revista Latinoamericana, núm. 2, 2009, pp. 121-161. Disponível em: https://www.epublicacoes.uerj.br/index.php/SexualidadSaludySociedad/article/view/32/445. Acessado em. 22.04.2019.

OKA, Mateus; LAURENTI, Carolina. Entre sexo e gênero: um estudo bibliográficoexploratório das ciências da saúde. Saude soc., São Paulo, v. 27, n. 1, p. 238-251, jan. $2018 . \quad$ Disponível em: <http://www.scielo.br/scielo.php?script=sci_arttext\&pid=S0104$12902018000100238 \&$ Ing=en\&nrm=iso >.

Acessado em: 26 Apr. 2019. http://dx.doi.org/10.1590/s0104-12902018170524.

ORGANIZAÇÃO MUNDIAL DE SAÚDE. (OMS) Género. Temas de salud. 2018. Disponível em: https://www.who.int/topics/gender/es/. Acessado em 22.04.2019.

POYNTER, Kerry J., WASHINGTON, Jamie. Multiple identities: creating community on campus lor LGBT students. New directions for students' services. No. 111. Wiley Periodicals, Inc. Outono de 2005. DOI: https://doi.org/10.1002/ss.172.

PRAUN, Andrea Gonçalves. Sexualidade, gênero e suas relações de poder. Revista Húmus. Jan/Fev/Mar/Abr № 1. 2011. Disponível em: http://www.periodicoseletronicos.ufma.br/index.php/revistahumus/article/view/1 641. Acessado em 26.04.2019. 
SILVA, Renan Antonio. Trans, ideologia da violência, criando personagens de direitos no Brasil. In: SILVA, Paulo Celso da; ROVIDA, Mara; LOPES, Felipe T. P. e GARCIA, Wilton (orgs.) Gêneros, diversidades, tecnologias e smart city. EDUNISO: Sorocaba. 2018

SILVA, Deborah R. da e POLONI, Paula Keiko I. A democratização da mídia ao representar travestis e transexuais. In: SILVA, Paulo Celso da; ROVIDA, Mara; LOPES, Felipe T. P. e GARCIA, Wilton (orgs.) Gêneros, diversidades, tecnologias e smart city. EDUNISO: Sorocaba. 2018

WOODFORD, Michael R., SILVERSCHANZ Perry, SWANK, Eric, SCHERRER, Kristin S. e RAIZ, Lisa Predictors of Heterosexual College Students' Attitudes Toward LGBT People, Journal of LGBT Youth, 9:4, 2-12. 297-320, DOI: 10.1080/19361653.2012.716697 


\title{
POLÍTICA DE ACESSO E PERMANÊNCIA DE PESSOAS COM DEFICIÊNCIA VISUAL NA UNIVERSIDADE
}

\author{
MOURA, Arthur de Lucca Veronez Galdiano \\ Graduando em Direito - UEMG \\ arthur.galdiano@outlook.com \\ GIMENES, Priscila Alvarenga Cardoso \\ Doutora em Educação Especial - UEMG \\ Priscilagimenes1@gmail.com
}

\section{INTRODUÇÃO}

Atendendo aos dispositivos legais e resultante do entendimento social de que todas as pessoas têm direito a educação, a inclusão de alunos com deficiências em todos os níveis de ensino tem se tornado realidade em diversas unidades escolares do país. Entretanto a inclusão destes alunos nas escolas exige que as mesmas se organizem para oferecer educação de qualidade para estes alunos, o que, em alguns casos, impõe a exigência da utilização de estratégias pedagógicas diversificadas e recursos pedagógicos e de acessibilidade específicos para assegurar a equidade no processo educacional.

O presente artigo tem como objetivo apresentar o trabalho desenvolvido no Projeto política de acesso e permanência de pessoas com deficiência visual na universidade (PAEX/PROEN), implantado pela Universidade do Estado de Minas Gerais na unidade de Frutal.

O projeto consiste na disponibilização de um estudante bolsista, chamado aluno ledor para acompanhar e auxiliar o aluno com deficiência visual, com o intuito de cumprir a legislação nacional atual que preconiza oportunizar aos alunos com deficiências o acesso ao currículo.

Em se tratando do aluno com deficiência visual, a presença de uma pessoa que realize a leitura de materiais não digitalizados, digitalize os materiais impressos e converta-os em arquivos de editor de texto, acompanhe e auxilie no desenvolvimento das atividades educativas é de grande relevância e possibilita que o ambiente escolar torne-se menos restritivo.

A unidade da UEMG de Frutal conta com uma aluna que durante 2018 frequentou o quarto ano de Direito e possui deficiência visual, o que justifica a presença do aluno ledor, tendo em vista que, embora possua autonomia para a realização das atividades de vida diária, ela encontra 
dificuldades para acompanhar as aulas, sobretudo nas quais é exigida a leitura no quadro negro, slides, livros ou textos impressos).

Entretanto, é fundamental que o aluno ledor conheça sobre a deficiência visual e as estratégias para auxiliar a pessoa com deficiência visual tanto durante as aulas, quanto nas atividades extra classe, tais como elaboração de trabalhos e preparação para as avaliações.

Neste sentido ao coordenar as ações do aluno ledor foram oferecidas orientações para que sua ação contribua, ao máximo com o desenvolvimento acadêmico da aluna com deficiência visual e periodicamente a aluna foi consultada, buscando compreender melhor suas estratégias de aprendizagem e suas necessidades, com o intuito de minimizar as barreiras encontradas no ambiente escolar.

O aluno ledor mostrou-se ao longo de todo o projeto, muito empenhado em possibilitar que a aluna fosse atendida em suas necessidades educacionais, auxiliando-a tanto durante as aulas quanto na realização de trabalhos ou preparação para as avaliações. De acordo com a aluna, o apoio do aluno ledor foi de grande relevância para sua aprendizagem

\section{A INCLUSÃO DE PESSOAS COM DEFICIÊNCIA NO ENSINO SUPERIOR}

A inclusão de pessoas com deficiências no ensino superior é um fenômeno recente nas universidades e demais intuições que oferecem este nível de ensino no país, tendo em vista que o processo de inclusão no ensino fundamental e médio e a oportunidade de participação social plena das pessoas com deficiências na sociedade é um fato recente na história do país.

Mazzotta (2005), Januzzi (2006), Mendes (2010), Bueno (2003), Caiado (2003) entre outros apontam que até meados do Século XX as ações nacionais em prol das pessoas com deficiência tinham em sua maioria, caráter segregatório, assistencialista e filantrópico, assumindo uma visão médica terapêutica e não eram suficientes para atender toda a população.

Com as lutas sociais empreendidas pelas pessoas com deficiências após a década de 1950 em diversos países da Europa, os organismos internacionais começaram a intervir com propostas e discussões sobre os direitos destas pessoas, vislumbrando o processo de integração em todas as áreas da sociedade. Este movimento resultou em diversas declarações internacionais que influenciaram os governantes de várias nações a dotar seus princípios.

No Brasil estas ideias tiveram maior repercussão após a década de 1990, sendo que até então, as propostas de atendimento às pessoas com 
deficiência eram oferecidas em escolas especiais e classes especiais, porém poucas pessoas tinham acesso a estes serviços, nos quais prevalecia a visão médica terapêutica. Pois como afirma Jannuzzi (2006 ) a história da Educação Especial no Brasil é marcada pelas vertentes médica e psicológica, cuja ênfase explicativa para as dificuldades encontradas na vida está na própria deficiência, justificando todo esforço clínico para superar o comprometimento orgânico ou funcional, assim como, a criação de espaços sociais exclusivos como: escolas especializadas e oficinas de trabalho protegido. Para Mazzotta (2005, p.1), a educação inclusiva pressupõe:

Abordagem dinâmica (unidade entre comum e especial) como aquela que, baseada no princípio da não segregação, possibilita a melhor compreensão da relação entre o educando e a educação escolar e comporta a organização de situações de ensino-aprendizagem mais condizentes com as necessidades educacionais a atender.

Em meados dos anos 2000, acompanhando um movimento mundial de defesa pela educação inclusiva enquanto proposta educacional que possibilita que todos os alunos frequentem um mesmo ambiente escolar e tenham seus direitos à aprendizagem garantida, compreendendo a escola como um espaço que acolhe, compreende e atende as necessidades de todos os alunos, inclusive dos que possuem deficiências (Bueno, 2004), diversas crianças com deficiências começassem a frequentar as escolas regulares.

A presença destas crianças na escola esteve acompanhada da exigência de mudanças para atender às suas necessidades, exigindo do poder público, das escolas e dos docentes mudanças em sua forma de conceber a educação e de propor ações educativas.

A principal mudança proposta dizia respeito à compreensão de que todas as crianças aprendem e tem direito a propostas educativas que respeitem suas limitações, entretanto que também estimulem suas potencialidades, oferecendo recursos e estratégias que possibilitem que todos os alunos sejam atendidos na escola com equidade.

Uma das mudanças necessárias foi a oferta de recursos diferenciados para assegurar às crianças com deficiências o acesso ao currículo escolar, para que tenham condições de aprender e alcançar o sucesso em seu processo de escolarização. Dentre os recursos oferecidos é válido ressaltar os materiais como mobiliário, próteses, órteses, cadeiras de rodas, materiais pedagógicos recursos computacionais, entre outros e também recursos humanos, como tradutor de libras para alunos com deficiência auditiva, auxiliares para locomoção, alimentação e higiene de alunos com comprometimentos físicos e motores e acompanhantes para alunos com deficiência visual, quando necessário.

Embora nem todas as escolas tenham se adequado ainda às propostas da educação inclusiva, muitos alunos que iniciaram sua vida escolar 
na década dos anos 2000 tiveram a oportunidade de cursar a educação básica e estão ingressando na universidade. No que diz respeito à criança com deficiência visual, Caiado (2003, p. 39) afirma que:

\begin{abstract}
A aprendizagem humana se dá com base na convivência social, na apropriação das atividades historicamente engendradas pelos homens, pela internalização dos significados sociais. Assim, 0 homem conhece o mundo pela atividade simbolizadora nas relações sociais. Toda atividade humana é constituída de significados que são mediados, de um homem para o outro, pela linguagem, que é o sistema simbólico básico de comunicação de todos os grupos humanos.
\end{abstract}

Desta forma, quando oferecido aos alunos a oportunidade de desenvolvimento, os resultados são satisfatórios.

Este quadro exige que também a universidade busque meios para atender as necessidades dos alunos com deficiências, para que estes tenham seus direitos de acesso e aprendizagem assegurados. Neste sentido, a proposta de um projeto que disponibiliza o acompanhamento de um aluno ledor (bolsista) para auxiliar o aluno com deficiência visual tem se mostrado de grande relevância e possibilitado que os alunos com esta deficiência alcancem sucesso em sua formação.

2.1 Desenvolvimento do Projeto Política de acesso e permanência de pessoas com deficiência visual na universidade (PAEX/PROEN) na unidade Frutal e resultado alcançados

O projeto política de acesso e permanência de pessoas com deficiência visual na universidade (PAEX/PROEN) foi desenvolvido na Universidade do Estado de Minas Gerais - unidade Frutal, entre os meses de abril a dezembro do ano de 2018

A realização do projeto contou com reuniões periódicas para orientações ao aluno ledor, com momentos de estudos, indicações de leituras, discussões e reflexões sobre a deficiência visual, o processo de aprendizagem das pessoas com esta deficiência, estratégias pedagógicas, recursos e materiais que facilitam o processo de aprendizagem e desenvolvimento de alunos com deficiência visual e consequentemente minimizam as barreiras para a aprendizagem. Esta ação teve o intuito de facilitar o manejo do aluno ledor com a pessoa com deficiência visual buscando contribuir com a autonomia e independência da aluna na universidade.

Também foram realizados encontros com a aluna com deficiência visual, para identificar suas potencialidades e necessidades e com base nestas informações traçar as estratégias para atuação do aluno ledor. Foram sugeridos diversos recursos de acessibilidade que poderiam ser utilizados pela 
aluna, como softwares, sites com materiais específicos, além de orientações para potencializar seu processo de aprendizagem tanto durante as aulas quanto nas demais atividades escolares ou de vida diária.

O aluno ledor também frequentou o quarto ano de Direito ao longo do ano de 2018, o que facilitou o acompanhamento da aluna nas aulas, leitura dos materiais apresentados pelos professores e o auxílio em suas dificuldades, tendo em vista que também estudava os mesmos assuntos e realizava as mesmas leituras. Outro aspecto que também facilitou a atuação do aluno ledor fora do ambiente escolar foi que ele reside no mesmo condomínio que a aluna com deficiência visual e estabeleceu horários para estudar com ela e preparar os materiais necessários (digitar ou digitalizar os materiais impressos e salválos em formato de Editor de texto), auxiliar na realização dos trabalhos escolares, exercícios e demais atividades relacionadas à rotina acadêmica.

Ao longo do desenvolvimento do projeto o aluno mostrou-se muito empenhado e preocupado com o processo de aprendizagem da aluna, buscando meios para contribuir com seu processo de aprendizagem De acordo com a aluna, o apoio do aluno ledor foi de grande relevância para sua aprendizagem.

A experiência do desenvolvimento do projeto foi narrada em um artigo científico e foi encaminhado para publicação.

A seguir são apresentados os relatos (na íntegra) do aluno ledor e da aluna com deficiência visual sobre o desenvolvimento do projeto que fazem parte do artigo sobre o desenvolvimento do projeto.

\subsection{Registro da aluna com deficiência visual}

Registro da aluna com deficiência visual atendida no Projeto política de acesso e permanência de pessoas com deficiência visual na universidade (PAEX/PROEN - 2018):

O projeto do ledor trouxe inúmeros avanços para que ocorra uma maior colaboração na construção do conhecimento, pois o ledor é aquele que lê em voz alta para outra pessoa que, ouvindo a leitura do ledor, torna-se leitor ainda que não disponha dos olhos para ler, a importância do ledor como mediador facilita o acesso do aluno da universidade em textos, livros, nas avaliações e trabalhos, nas orientações dos estudos, na realizações de atividades e acima de tudo auxilia no processo de estudos, juntamente com a intermediação do professor aluno facilitando o avanço significativo, intelectual e acadêmico. 
Ao entrar na universidade enfrentei vários obstáculos devido a falta do ledor, encontrei grandes desafios diante da falta de recursos e materiais disponíveis para que conseguisse ter as mesmos oportunidades de aprendizagem que os demais alunos, muitas vezes me senti desmotivada, pois minha aprendizagem era limitada e essa comunicação professor-aluno era distante. Somente no meu terceiro ano acadêmico foi oferecido pela Universidade a possibilidade de obter um ledor, comecei então a ter uma assistência e uma maior acessibilidade nos livros e materiais, faço estudo diários, esclarecendo as dúvidas das aulas, estudando para as avaliações, realizando pesquisas e trabalhos onde o ledor é a peça fundamental para o meu melhor rendimento acadêmico proporcionando uma igualdade em relação aos demais estudantes, contribuindo para permanência e conclusão de todas as etapas do ensino.

Precisa existir além da aceitação no mesmo meio social, um convívio de igualdade em todas as atividades desenvolvidas. Nessa perspectiva precisamos compreender que nas universidades faltam a infraestrutura necessária para seu desenvolvimento, literatura especializada, equipamentos e monitoria especial. Mas através do ledor já podemos dizer que acontece uma transformação positiva e muito importante no processo de aprendizagem, o ledor se constitui um mediador entre $o$ autor do texto escrito $e$ o leitor-ouvinte cego.

Além de mim muitas outras pessoas já receberam o auxílio do ledor e também relatam a grande melhoria na qualidade do estudo, facilitando esse intermédio na aprendizagem.

\subsection{Registro do aluno ledor}

Registro do aluno ledor, bolsista do Projeto política de acesso e permanência de pessoas com deficiência visual na universidade (PAEX/PROEN - 2018):

O papel de ledor na Unidade de Frutal da UEMG neste ano de 2018 foi regulado pelo edital PROEX/PROEN № 03/2018, que objetivou a seleção de alunos para "acompanhar os discentes deficientes visuais da UEMG nas atividades acadêmicas que se fizerem necessárias nas dependências e/ou fora da Instituição...". O referido edital abrange todas as unidades da UEMG que contam com um discente deficiente visual. No ano de 2017, a Unidade de Frutal criou um programa para si, nos mesmos moldes do atual edital, ou seja, um aluno selecionado para assessorar um discente que necessitava. Portanto, em relação ao ano passado, se mostra um ganho na situação global da Universidade, já que agora a função de ledor não se resume a uma única unidade, mas se concretiza como uma política de permanência geral. 
Passemos a analisar a função de ledor a partir de suas quatro atividades-chave listadas no edital. A primeira, "ler cuidadosamente todos os materiais de leitura solicitados no período de aulas da Unidade". Neste ponto, entra tanto a atuação em sala de aula quanto fora dela. O ledor selecionado ser da mesma sala que a discente-alvo ajudou muito no processo, pois ambos assistem às mesmas aulas e estão no mesmo período do curso de Direito. Assim, qualquer dúvida em relação ao conteúdo e a terminologia do que estava sendo lido era mais facilmente respondida, e geralmente ocasionava debate e estudo sobre o que estava sendo lido, além de uma mera leitura.

Dentro de sala de aula, a atuação do ledor focou-se em fazer uma interpretação visual de elementos como desenhos e tabelas para a aluna-alvo, além da leitura de textos passados em lousa e em slides. Desta forma, a discente deficiente visual tem acesso a tudo o que está ocorrendo durante a explanação oral do professor. A integração dos elementos orais e não-orais permite que a aluna-alvo possa receber a totalidade do conteúdo passado durante a aula. Percebeu o ledor, ao longo do desempenho de suas funções, $o$ quanto há de elementos visuais durante uma aula expositiva, que mesmo a disposição do texto em um slide ou lousa interfere no que o professor busca passar ao aluno, e que a parte oral de uma aula não é mais importante para se absorver o conteúdo.

Fora da sala de aula, a atuação do ledor foi convencionada com a discente deficiente visual da seguinte forma: haveria a leitura do material passado pelo professor naquele dia, junto a doutrinas e legislação que se relacionassem aos tópicos lidos e também, se a aluna-alvo assim quisesse, a realização de alguns exercícios. Foi assim a maior parte do período letivo, mas este modelo não permaneceu estático e foi alterado ao longo do ano, para que a processo de leitura fosse o mais eficaz possível dentro de cada época. A leitura realizada por um ledor tem o objetivo de ser uma tradução oral de como seria se a própria aluna-alvo estivesse lendo. Assim, conforme instruções da orientadora do projeto, deu-se relevância durante a leitura principalmente na entonação e no ritmo, sempre consultando a discente para saber se ela estava compreendendo bem. Além disso, se explicava como o texto estava organizado, algo primordial na leitura da legislação, por exemplo, (por esta ser dividida em títulos, capítulos, seções, etc.), já que ler um artigo sem dizer onde ele está na lei pode gerar graves erros de hermenêutica. $O$ uso de parênteses e aspas em citações também é algo muito importante para uma melhor absorção de um texto.

A segunda atividade-chave, conforme o edital: "digitar materiais impressos e salvá-los em formato de Editor de texto". A aluna-alvo usa o programa NVDA para poder utilizar o computador, que é a única ferramenta pela qual ela tem acesso aos textos escolares. Apesar de alfabetizada no sistema Braille, ela não tem costume de usá-lo por não ter se adaptado, conforme relatou. Observa este ledor que, através da orientadora, soube de alguns aparelhos que hoje 
tornam o acesso ao deficiente visual a textos escritos muito mais fácil e prático, como os digitalizadores e até mesmo óculos-leitores.

Em relação a esta atividade, procedeu-se principalmente com a digitação do material apresentado em sala de aula, tanto advindo da lousa quanto dos slides, e também com alguns, não apresentados pelos professores, mas pedidos pela aluna-alvo. Também procurou-se dar acesso ao maior número possivel de doutrinas por meio da conversão do formato de seus arquivos digitais para um lido pelo NVDA. Desta forma, hoje a discente deficiente visual tem uma pasta com doutrinas de quase todos os ramos do Direito. As doutrinas são absolutamente necessárias aos estudantes de Direito, pois permitem o aprofundamento a interpretação da legislação estudada em sala de aula.

A terceira atividade, conforme o edital: "enviar e-mails com conteúdos acadêmicos, como trabalhos, exercícios e outros, acompanhando até a finalização das tarefas acadêmicas". Em relação ao uso do e-mail, a aluno-alvo mostrou bastante autonomia no uso de seu próprio e no do coletivo da turma, tanto que a atuação do ledor se limitou a digitar os endereços de e-mails dos destinatários e revisar o português. Já o acompanhamento das tarefas acadêmicas se deu pela leitura das questões e a transcrições das respostas ditadas pela aluna-alvo nos questionários mais simples, tanto dentro quanto fora da sala de aula. Para trabalhos mais complexos (artigos, seminários, etc...), atuei preparando material para ser lido pelo NVDA e na revisão do português.

Para a realização de provas, a discente e o professor convencionavam como seria o método de avaliação. Houve provas orais e avaliações feitas pelo computador, que não necessitaram da atuação do ledor. Porém, por exemplo, na disciplina Direito Civil, o ledor lia a prova e transcrevia as respostas, tanto as de múltipla escolha quanto as expositivas. Neste sistema, o ledor realizava a sua prova primeiro e depois auxiliava a aluna-alvo a realizar a dela.

A última atividade-chave imposta pelo edital é a de "contribuir para acessibilidade aos espaços e conteúdos curriculares dos estudantes com deficiência, acompanhando-os nos ambientes e nas situações escolares pertinente". Em relação a esta, como qualquer outro discente do curso de Direito, a aluna-alvo tinha e tem a necessidade de cumprir diversas atividades extraclasses, como palestras, congressos, apresentações de papeis científicos e estágio. A discente em questão realizou todos estes exemplos neste ano, sendo que a atuação do ledor foi acompanhar a aluna-alvo, tanto como apoio para se locomover (já que a mesma não usa bengala ou cão-guia) quanto para realizar a interpretação visual e leituras nos casos necessários. Em relação ao estágio que ela desempenha na Câmara Municipal, atividade do cotidiano, o ledor a acompanha para ir já que este faz o seu no Fórum local, que é do lado.

Em conclusão, observa o ledor que a experiência ganha em sua atuação ancora-se em dois pontos: a) foi um estímulo para estudar mais e também a leitura realizada dos textos das disciplinas já servia como um estudo para o 
ledor, o que contribui para se tornar um estudante mais preparado e b) a percepção de como as estruturas e as pessoas não sabem lidar com a deficiência visual. Em relação ao ponto b), ressalta-se a invisibilidade da alunaalvo por professores e colegas, especialmente os primeiros, que muitas vezes tratavam de questões com o ledor mesmo quando a mesma estava por perto e podia responder por si e, nunca antes da criação do posto de ledor, preocupavam-se em pensar na situação da aluna-alvo, bem na frente deles.

Como o ledor, pela relação de amizade anterior ao projeto e ser da mesma turma da aluna-alvo, já presenciava a situação dela e lhe ajudava a estudar da forma que conseguia, este pode relatar: que a criação de um posto como o ledor ajudou na inclusão da deficiência visual de um discente como algo que as estruturas administrativas e pedagógicas da unidade não podem mais negar e invisibilizar, já que o ledor tem a força do seu posto para fazer professores e gestores ouvirem a voz de uma discente que necessitava de apoio. Além disso, que o realizado pelo ledor não é mera "leitura", pois exige uma gama de técnicas e tem características próprias, como descrito acima (a entonação, a pontuação, a interpretação visual, etc...).

Por fim, cabe ressaltar que a consequência de quando se há apoio, não é a dependência, mas sim a busca por autonomia e espaço próprio, busca que orientadora e ledor estimularam, sendo com conversas sobre o uso da bengala e outras, e este último afirma ter testemunhado muito mais este ano do que nos anteriores.

A viabilidade e necessidade um projeto de ledor se mostra no que ocorreu com a aluna-alvo no ano corrido e que traduziu como ganho de dignidade humana, o princípio basilar que rege o nosso Estado de Direito.

\section{CONSIDERAÇÕES FINAIS}

É de fundamental importância que as universidades e instituições de ensino superior busquem meios para favorecer o processo de inclusão de alunos com deficiências e o acesso ao currículo, para que estes tenham a oportunidade de se desenvolver pessoalmente e profissionalmente.

Como observado nos registros apresentados pelo aluno ledor e pela aluna com deficiência visual, o desenvolvimento do projeto foi de grande relevância e possibilitou que a aluna participasse plenamente das aulas, usufruindo de todos os recursos utilizados pelos docentes e também contribuiu para o processo de aprendizagem do aluno ledor.

Embora tenha atingido diretamente apenas um aluno com deficiência visual, indiretamente diversos colegas de turma, docentes e demais profissionais que atuam na UEMG Frutal também foram influenciados pela realização do projeto, pois puderam refletir sobre o processo de escolarização 
de pessoas com deficiências, sobre estratégias pedagógicas e recursos de acessibilidade.

No geral, o projeto atingiu seus objetivos e precisa ser consolidado como uma política da Universidade.

\section{REFERÊNCIAS}

JANNUZZI, Gilberta.. A educação do deficiente no Brasil: dos primórdios ao início do século XXI. 2. ed. Campinas/SP: Autores Associados, 2006.

MAZZOTTA, Marcos. Educação especial no Brasil: história e políticas públicas. 5 ed. São Paulo: Cortez, 2005.

BUENO, José Geraldo. Educação especial brasileira: integração/segregação do aluno diferente. 2 ed. São Paulo: EDUC, 2004.

CAIADO, Kátia. Aluno deficiente visual na escola: lembranças e depoimentos. Campinas: Autores Associados, 2003.

MENDES, Enicéia Gonçalves. Breve histórico da educação especial no Brasil. Revista Educación y Pedagogía, vol. 22, núm. 57, maio-agosto, 2010. 


\title{
POVOS INDÍGENAS E O ENSINO DE HISTÓRIA: Prática pedagógica em uma sala do 6ำ ano do Ensino Fundamental
}

\author{
CARRARO, Mariana \\ Graduanda em História - UNESP Franca \\ maricarraro98@gmail.com \\ FERREIRA, Alessandra Freitas Lopes \\ Pedagoga e professora de História, especialista em \\ Psicopedagogia e Tecnologia EAD \\ educadales@hotmail.com \\ MARTINO, Vânia de Fátima \\ Vice-coordenadora do Programa de Pós-graduação em \\ Planejamento e Análise de Políticas Públicas - UNESP Franca \\ vania.martino@unesp.br
}

\section{INTRODUÇÃO}

A abordagem da temática indígena na escola básica sempre foi limitada, geralmente citada no estudo da chegada dos portugueses em 1500 e no "Dia do Índio". Da mesma forma, no século XIX a história nacional foi construída com base na teoria das três raças, desenvolvida pelo Instituto Histórico e Geográfico Brasileiro, em que o branco possuía papel de protagonista e herói nacional e o negro e o indígena eram situados como coadjuvantes, responsáveis pela força de trabalho (COELHO; MELO, 2016).

O mito da democracia racial, ainda muito presente no pensamento social brasileiro, considera que não existe racismo no Brasil devido à forte miscigenação. Essa perspectiva considerou uma suposta "assimilação" dos povos indígenas e consequente apagamento de suas especificidades em nome de uma ideia generalista do "ser brasileiro". Segundo Miguel Arroyo (2011, p. 143):

As ausências dos sujeitos populares não se dão por ingênuo esquecimento, mas, tem uma intencionalidade política, fazem parte dos processos políticos de segregação desses coletivos nos diversos territórios sociais, econômicos e culturais.

No final do século passado, começa a se formar o campo de estudos de História Indígena, que tem como principais nomes o historiador John Monteiro e a antropóloga Manuela Carneiro da Cunha. Esse campo têm se moldado em constante diálogo com a Antropologia, e busca estudar a inserção dos povos indígenas no espaço colonial para além da resistência à 
ação europeia, considerando-os atuantes nessa sociedade, e buscando resgatar sua perspectiva dos processos históricos.

O ensino de História, que sempre foi voltado à formação para a cidadania (COELHO; BICHARA, 2017) foi impactado nos últimos anos com leis que buscam tratar da diversidade cultural brasileira e de povos que têm tido sua história invisibilizada sistematicamente. A lei no 11.645 de 2008 alterou a lei no 10.639 de 2003, que incluía no currículo da educação básica o ensino da história e cultura afro-brasileira, indicando a obrigatoriedade do ensino da história e cultura indígena nas escolas. A lei sancionada no dia 10 de março de 2008 busca atender reivindicações do movimento social indígena, postulando que

[...] incluirá diversos aspectos da história e da cultura que caracterizam a formação da população brasileira, a partir desses dois grupos étnicos, tais como o estudo da história da África e dos africanos, a luta dos negros e dos povos indígenas no Brasil, a cultura negra e indígena brasileira e o negro e o índio na formação da sociedade nacional, resgatando as suas contribuições nas áreas social, econômica e política, pertinentes à história do Brasil (BRASIL, 2008).

Contudo, a aplicação desta lei esbarra em diversos obstáculos, entre eles a falta de uma formação docente que aborde o tema e a falta de diálogo entre esses novos estudos e a prática pedagógica da escola básica. Nesta perspectiva, a escola, inserida na sociedade, acaba reproduzindo seus preconceitos, e cabe a nós, profissionais da educação, questioná-los. Em uma escola pública do município de Franca/ SP, buscamos trabalhar a história e cultura indígena com uma sala do $6^{\circ}$ ano do Ensino Fundamental II e contornar essas dificuldades.

Consideramos que a parceria entre universidade e escola básica proporcionada pelo projeto Residência Pedagógica/ CAPES, do qual fazemos parte, possibilita a aplicação de projetos como este. Ao professor da educação básica e ao aluno da graduação o programa possibilita uma formação mais completa, unindo prática e teoria, experiência e inovação.

\section{PRÁTICA PEDAGÓGICA}

Após abordar o tema Pré-história da América, adentramos na préhistória brasileira, começando, assim, a trabalhar a história dos povos indígenas no Brasil. Neste primeiro momento, utilizamos como metodologia a leitura e interpretação de textos do livro didático e aula expositiva, mostrando, com o auxílio do Datashow, diversos vestígios desse período e alguns sítios arqueológicos existentes no país, como o de Lagoa Santa (MG). Com essa atividade, ressaltamos a presença dos povos indígenas no território brasileiro 
anteriormente à chegada dos europeus e a diversidade cultural existente, destacando suas diversas formas de vida e subsistência10. Discutimos, portanto, a história indígena tendo estes povos como protagonistas, como agentes históricos.

O recorte temporal abordou as teorias de estabelecimento dos primeiros grupos humanos onde hoje é o Brasil até 1500, com o primeiro contato dos povos originários com europeus. Trabalhamos o choque cultural ocorrido, através das noções de "eu" e "outro", e como este embate, apesar de não ter tido os povos indígenas como agentes passivos, impactou-os de forma negativa - a partir de conflito direto, doenças, escravização, entre outros fatores.

Buscamos, ainda, trazer a temática indígena para o presente. Em uma tela, mostramos um apanhado dos nomes de todos os povos indígenas existentes no Brasil segundo o Instituto Socioambiental, o que provocou intensa curiosidade dos alunos. O Censo IBGE de 2010 divulgou que, naquele ano, 896.917 pessoas se autodeclaravam indígenas, sendo que 324.834 viviam em cidades e 572.083 em áreas rurais, e pertenciam a 255 grupos diferentes11. Apesar dessa diversidade e das mudanças ocorridas ao longo do tempo, quando perguntados qual a imagem que lhes vêm à cabeça quando dizemos "índio", os alunos apontaram estereótipos tradicionais: cocares, arco e flecha, pinturas corporais e nudez.

Observamos, então, que os alunos possuíam uma visão genérica e estereotipada do indígena, que, mesmo após tanto anos de história, é semelhante a imagem que tiveram os primeiros colonizadores. Tal ponto de vista foi constatado também em outras práticas pedagógicas que constam em nossa bibliografia.

Refletindo sobre essas imagens que os alunos reproduzem, é possível entender porque é mais difícil para eles reconhecerem os povos indígenas contemporâneos, pois a imagem que a educação escolar ajuda manter é de um indígena do passado. Podemos dizer que, em geral, os saberes selecionados oficialmente nas escolas desconsideram a pluralidade de povos indígenas [...], relegando-os a uma visão generalizada (BERGAMASCHI; BARTH, 2012, p. 57).

Discutimos, também, as diversas situações que enfrentam os povos indígenas hoje, como os conflitos no campo e a demanda pela demarcação de terras, o acesso à saúde e educação, o preconceito e a desinformação da sociedade. Exibimos para a sala um vídeo do canal do Youtube Wariu12, do jovem indígena Cristian Wariu, que relatou sua experiência enquanto indígena no século XXI. O recurso do vídeo foi

\footnotetext{
${ }^{10}$ Aqui, nos referimos aos povos coletores, caçadores e pescadores.

${ }^{11}$ INSTITUTO SOCIOAMBIENTAL. Quantos são?. Disponível em https://pib.socioambiental.org/pt/Quantos_s\%C3\%A3o\%3F. Acesso em 23 de jul. 2019.

${ }_{12}^{12}$ WARIU. O que é ser indígena no século XXI. Youtube. Disponível em https://www.youtube.com/watch?v=XDaS70F2fPw. Acesso em 19 de jul. 2019.
} 
importante pois deu voz a um indígena para falar sobre suas experiências, e gerou grande interesse nos alunos, já que a presença de um indígena no Youtube confronta suas ideias iniciais sobre esses povos. Ultimamente, diversas lideranças indígenas têm utilizado a internet como forma de dar voz a uma narrativa esquecida.

Dessa forma, tentamos mostrar que os povos indígenas não são povos apenas do nosso passado e que não ficaram congelados no tempo, tendo passado por transformações e adaptado valores de outras culturas. Mostramos, por exemplo, que existem indígenas que vivem nas cidades e que usam celular, e que isso não os torna menos indígenas.

Enfiaram na cabeça da maioria dos brasileiros uma imagem de como deve ser o índio: nu ou de tanga, no meio da floresta, de arco e flecha, tal como foi descrito por Pero Vaz de Caminha. E essa imagem foi congelada. Qualquer mudança nela provoca estranhamento. Quando o índio não se enquadra nessa imagem, vem logo a reação: "Ah! Não é mais índio". Na cabeça dessas pessoas, o "índio autêntico" é o índio de papel da carta do Caminha, não aquele índio de carne e osso que convive conosco, que está hoje no meio de nós (BESSA, 2002, p. 12).

Como atividade, foi proposta aos alunos a elaboração de um desenho que mostrasse algumas das dificuldades enfrentadas pelos povos indígenas em 1500 e nos dias atuais, dando-Ihes liberdade criativa para abordar o tema. Abaixo, temos uma amostra dos trabalhos desenvolvidos pelos alunos:

Imagem 1: desenho desenvolvido por aluno da sala em questão. No passado, o aluno destaca como desafios a escravização dos indígenas, doenças e disputas, e, no presente, apresenta o conflito por terra e o risco de assassinato. 


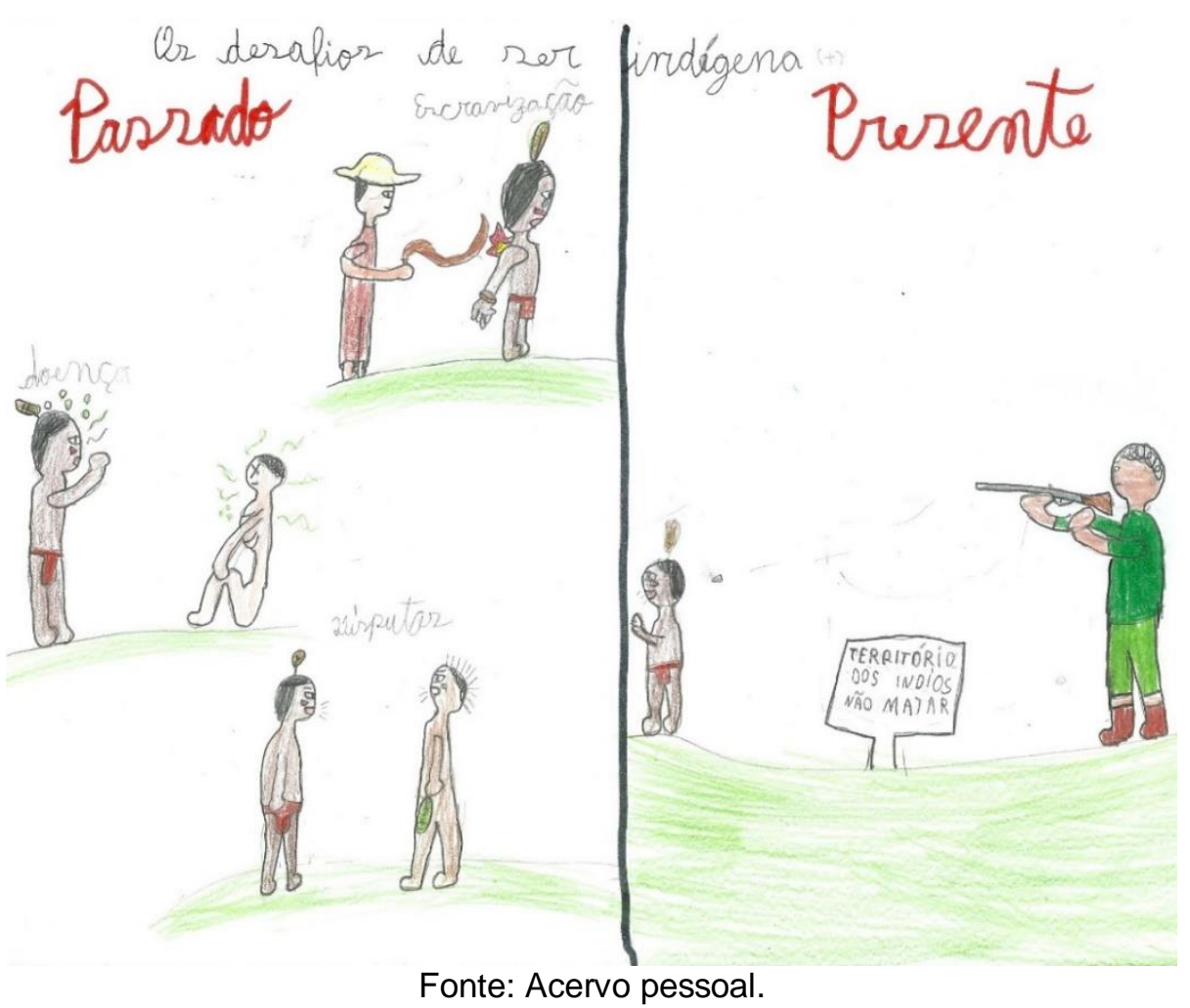

Imagem 2: desenho desenvolvido por aluno da sala em questão. No passado, o aluno destaca como desafios a escravização dos indígenas e, no presente, apresenta o conflito por terra.

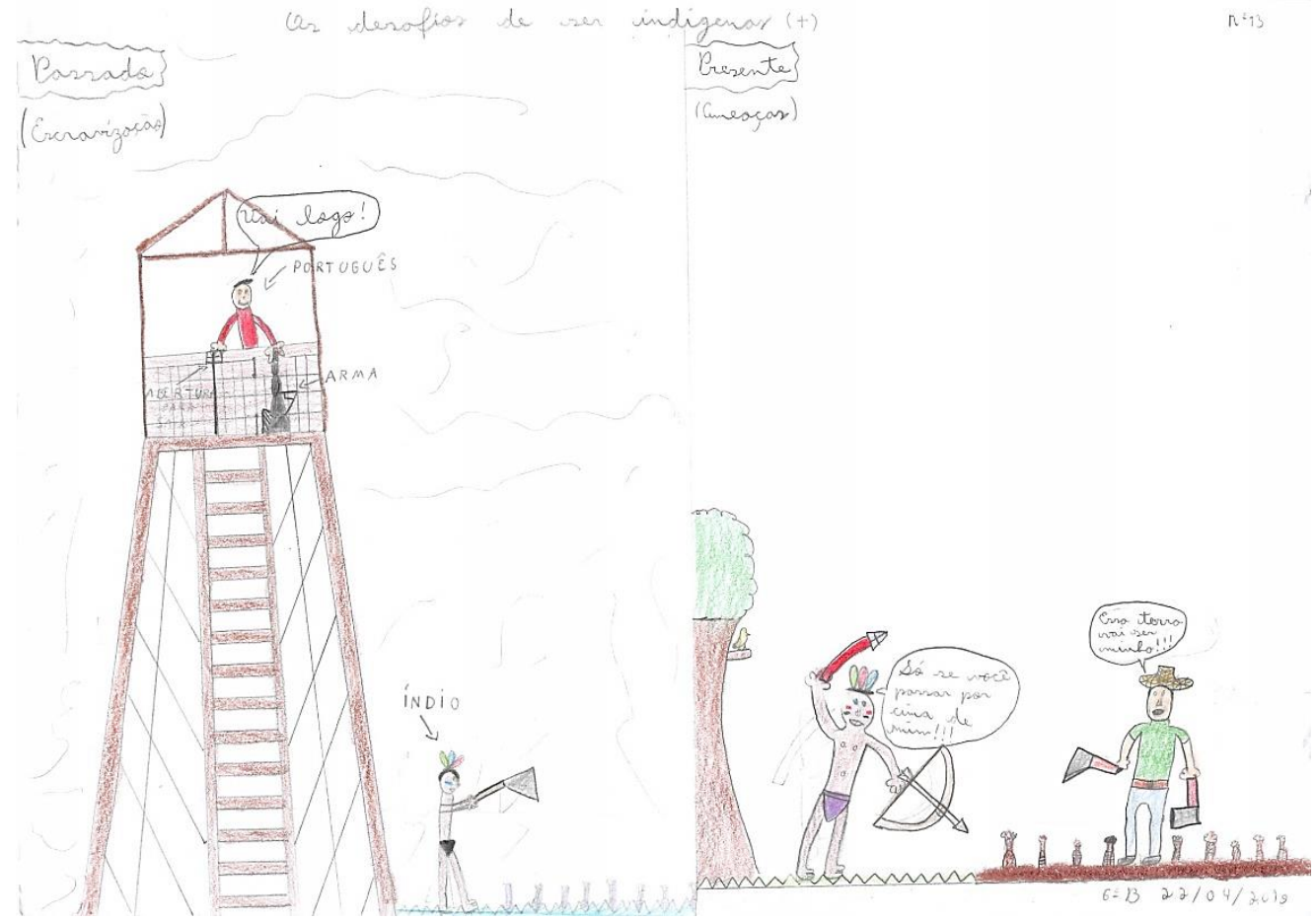

Imagem 3: desenho desenvolvido por aluna da sala em questão. No passado, a discente destaca como desafios a escravização dos indígenas e disputas, e, no presente, ameaças, apresentando uma mensagem particular sobre o assunto. Acervo pessoal. 


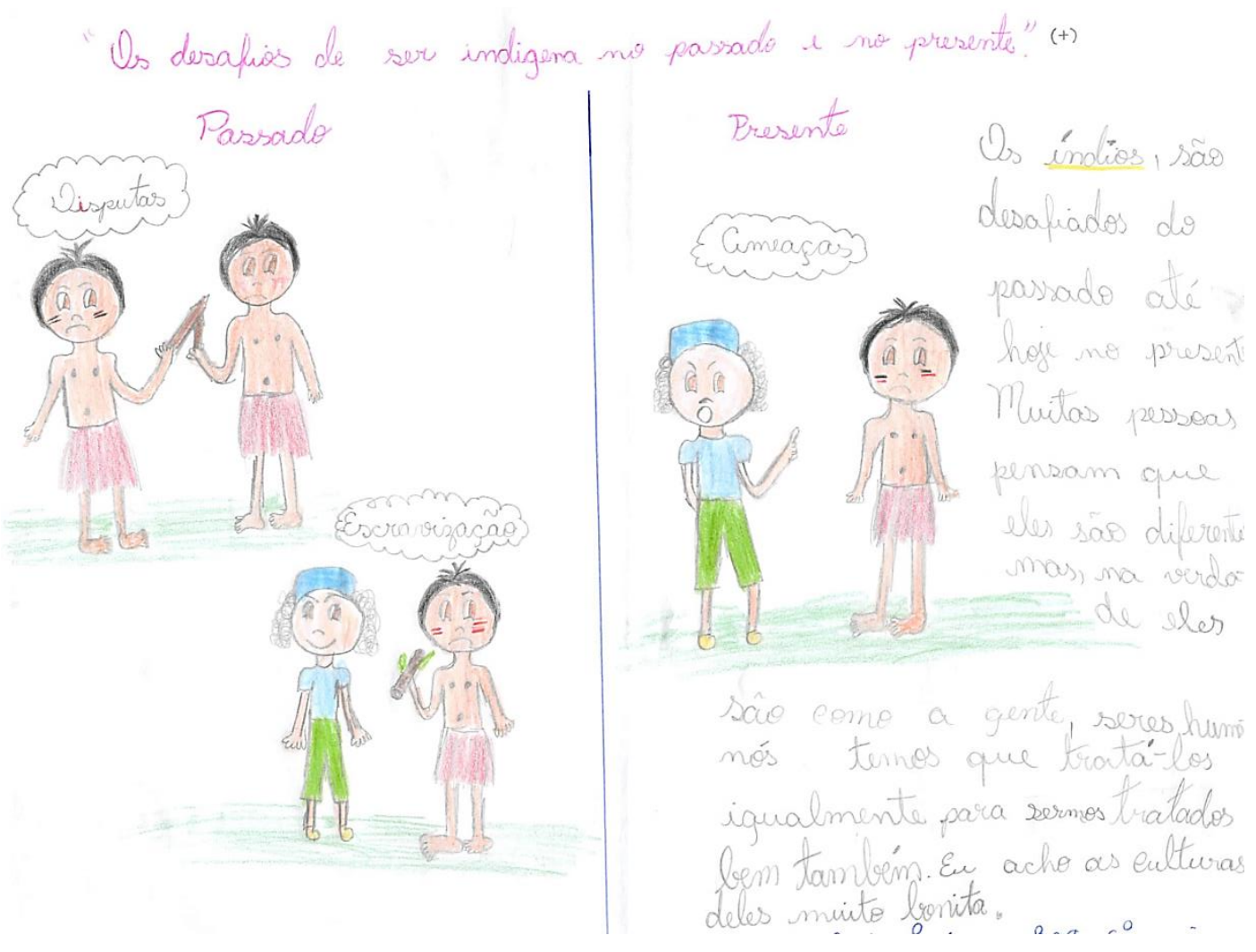

Analisando os trabalhos entregues, pudemos observar que, na coluna "passado", quase todos os alunos fizeram desenhos relativos à escravização dos nativos, tendo abordado também o contato com as doenças trazidas da Europa e o conflito direto entre portugueses e indígenas. Já no campo "presente", a maior parte dos alunos abordou os conflitos por terras existentes hoje no Brasil. Alguns, ainda, mencionaram preconceito e mudanças nos costumes que mencionamos em sala, como o uso de celular, roupas comuns e vivência nas cidades, demonstrando a quebra de alguns estereótipos que tinham em relação ao "índio".

De forma a aprofundar seus conhecimentos, constatamos que seria importante uma pesquisa sobre culturas indígenas na atualidade. Portanto, foram passadas orientações necessárias para a pesquisa, feita a divisão dos alunos em grupo e elaboração de um roteiro de pesquisa. Agendamos ainda, o dia em que trariam os resultados das pesquisas para a troca de informações e construção de cartazes na sala. Cada um dos sete grupos ficou responsável por pesquisar um povo indígena diferente, selecionados dentre os mais populosos atualmente: Guarani, Ticuna, Macuxi, Kaingang, Yanomami, Guajajara e Terena.

A proposta foi pensada para que não houvesse um reducionismo na herança cultural indígena, através da generalização destes povos, e da sua 
presença não só no passado mas também no presente brasileiro. Como afirma Bittencourt (2005, p. 42):

Várias pesquisas demonstram como textos e ilustrações de obras didáticas transmitem estereótipos e valores dos grupos dominantes, generalizando temas como: família, etnia, de acordo com os preceitos da sociedade branca burguesa.

No dia estabelecido, os alunos trouxeram suas pesquisas, com imagens e informações selecionadas dos sites que sugerimos - em especial, o site do projeto Povos Indígenas no Brasil, do Instituto Socioambiental (ISA)13. Em grupos, os alunos socializaram as pesquisas e montaram seus cartazes. Solicitamos que apontassem um breve histórico, localização e população aproximada de cada grupo, bem como buscamos dar autonomia e protagonismo aos alunos para a escolha de informações que chamaram a atenção deles sobre o povo indígena pesquisado.

Figura 4 - Cartazes elaborados pelos alunos sobre os Kaingang. Acervo pessoal.

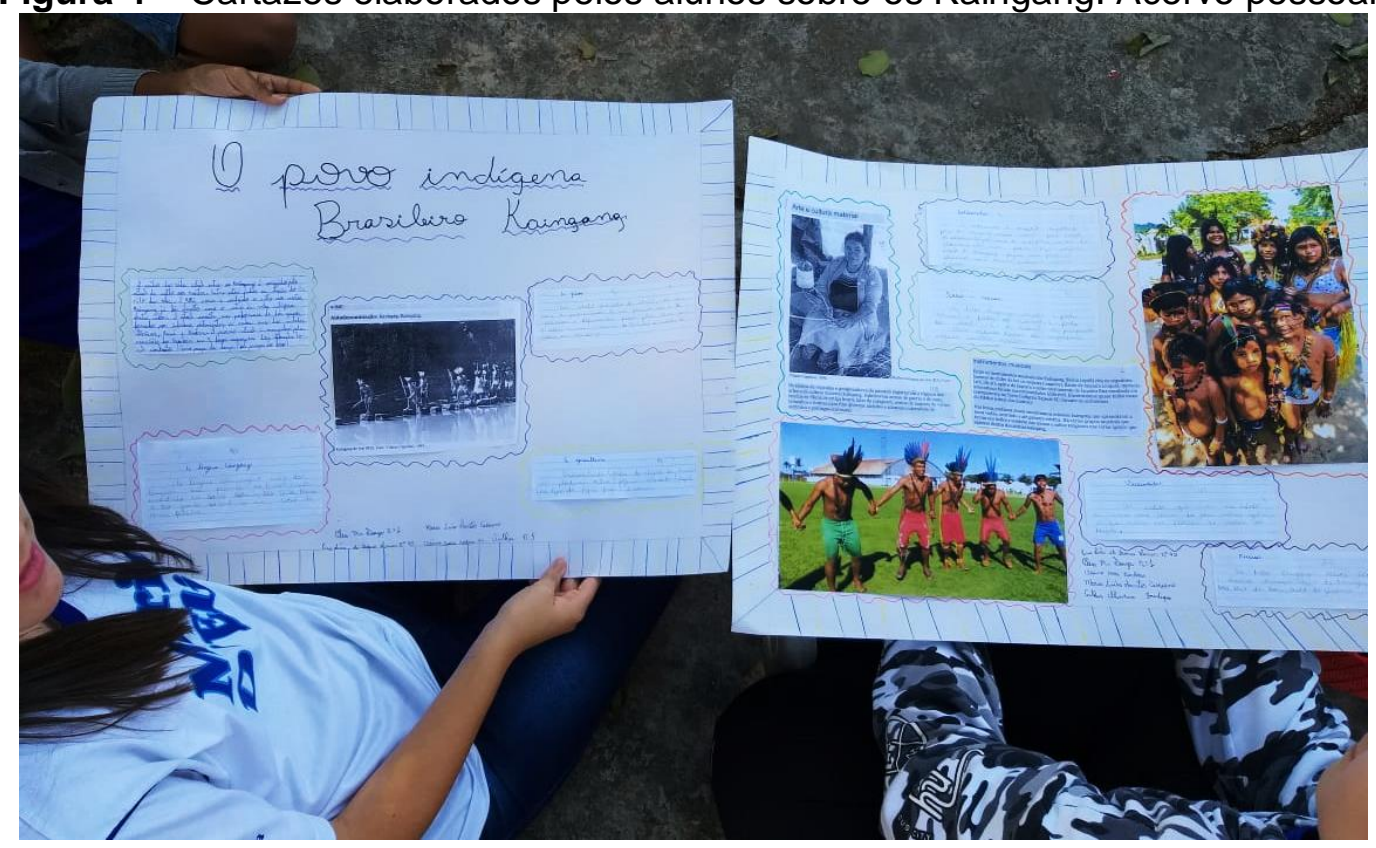

Logo após a montagem dos cartazes, os discentes tiveram um tempo para se prepararem e começaram as apresentações para a sala, exibindo seus cartazes e informações que consideraram importante

\footnotetext{
${ }^{13}$ POVOS INDÍGENAS NO BRASIL. Instituto Socioambiental. Disponível em https://pib.socioambiental.org/pt/P\%C3\%A1gina principal. Acesso em 18 de jul. 2019.
} 
compartilhar. Dessa forma, os alunos tiveram contato com sete culturas diferentes, ampliando seus saberes sobre diferentes povos indígenas, de diferentes lugares do Brasil.

Durante as apresentações fomos fazendo intervenções, no sentido de levar os alunos a refletirem a importância de conhecer os saberes e valores de cada povo pesquisado e de preservar e valorizar estas culturas. Ressaltamos, ainda, a importância de dar visibilidade à resistência e demandas desses povos ao longo da história.

\section{CONSIDERAÇÕES FINAIS}

As práticas pedagógicas acima relatadas foram realizadas com a intencionalidade de aplicar a Lei $11.645 / 08$ de forma reflexiva, buscando realizar ações concretas com o objetivo de valorizar a história e diversidade cultural indígena, em relação as suas lutas, a sua importância e as suas contribuições culturais na formação da cultura brasileira.

Procuramos problematizar junto aos alunos e apresentar fontes históricas que remetem a cultura indígena brasileira desde os paleoíndios, depois o contato com os portugueses e os dias atuais. Buscamos estabelecer relações entre presente e passado, incentivando e promovendo junto aos alunos a reflexão do que sabem, valorizando o seu protagonismo para que pudessem participar e construir uma visão mais ampla, rica de informações para a construção de um conhecimento dos povos indígenas mais amplo, justo e democrático.

Desde o começo do trabalho os alunos foram desafiados a pensar através de questionamentos nossos, ora da bolsista do Programa Residência Pedagógica, ora da preceptora e professora da sala. Foram relevantes, também, os questionamentos feitos por eles, sobre os preconceitos e estereótipos criados ao longo da História do Brasil em relação aos povos indígenas. De fato, foi uma experiência muito rica e significativa para os alunos e para nós, que aprendemos muito ao pesquisar e preparar as atividades.

Para Coelho e Coelho (2005, p. 42), o ensino das temáticas indígena e afro-brasileira nas escolas promove um redimensionamento da memória histórica, ao propor outras narrativas que se contrapõem ao paradigma europeu como nossa "matriz cultural máxima".

As narrativas sobre a nossa formação como país e como nação optaram pela Europa como paradigma e epicentro de nossa história e como nossa herança mais importante. Nelas, os povos africanos e indígenas assumiram o papel de coadjuvantes, cuja participação foi vista, com importantes exceções, de forma mais alegórica que determinante. A proposição dos movimentos sociais [...] determinou a inclusão desses antigos agentes do drama brasileiro sob uma nova 
perspectiva e Ihes atribuiu um novo estatuto: a partir do reconhecimento de sua História, os situa como atores relevantes da conformação do país e da nação.

Contudo, mais do que aplicar as leis na sala de aula, é essencial refletir sobre como fazê-lo. É importante não atribuir à história e cultura afrobrasileira e indígena um papel secundário, de menor valor, mas situar esses povos como atores importantes na história do país. Mais do que isso, devemos buscar formação qualificada para que, embasados, possamos combater noções errôneas e preconceituosas. A formação de docentes deve estar em constante diálogo com a produção historiográfica atual e com os movimentos indígenas, se atentando e apoiando suas reivindicações.

\section{REFERÊNCIAS}

ALMEIDA, Maria Regina Celestino de. Metamorfoses indígenas: identidade e cultura nas aldeias coloniais do Rio de Janeiro: Arquivo Municipal, 2003.

ARROYO, Miguel. Currículo, territórios em disputa. Petrópolis: Vozes, 2011.

ARRUTI, José Maurício. John Monteiro e o projeto ampliado de história indígena: Apresentação do Dossiê História e índios. História Social, Campinas, n. 25, p. 7-17, 2013.

BITTENCOURT, C. Identidades e Ensino de História no Brasil. In. CARRETERO, Mario; et.all. Ensino da História e Memória Coletiva. Porto Alegre. ARTIMED, 2007. BRASIL. Lei no 10.639, de 9 de janeiro de 2003. Diário Oficial da República Federativa do Brasil, Poder executivo, Brasília, DF, 10 jan. 2003. Disponível em http://www.planalto.gov.br/ccivil_03/leis/2003/l10.639.htm. Acesso em 12 de jul. 2019.

Lei $\mathrm{n}^{0} 11.645$, de 10 de março de 2008. BRASIL. Lei $\mathrm{n}^{\circ}$ 10.639, de 9 de janeiro de 2003. Diário Oficial da República Federativa do Brasil, Poder executivo, Brasília, DF, 11 mar. 2008. Disponível em http://www.planalto.gov.br/ccivil_03/_ato2007-2010/2008/lei/l11645.htm. Acesso em 12 de jul. 2019.

. Diretrizes Curriculares Nacionais para a Educação das Relações ÉtnicoRaciais e para o Ensino de História e Cultura Afro-Brasileira e Africana. MEC/SEF, 1998.

Parâmetros Curriculares Nacionais - História e Geografia. Brasília:

BERGAMASCHI, Maria Aparecida; GOMES, Luana Barth. A temática indígena na escola: ensaios de educação intercultural. Currículo sem Fronteiras, v. 12, n. 1, p. 5369, jan./abr. 2012.

CHAUÍ, Marilena. Manifestações ideológicas do autoritarismo brasileiro: escritos de Marilena Chauí. Vol 2. Belo Horizonte/São Paulo: Autêntica: Fundação Perseu Abramo, 2013. 
COELHO, Mauro Cezar; BICHARA, Taissa Cordeiro. A história de um passado "injusto": povos indígenas, livro didático e formação para cidadania. História Unicap, v. 4, n. 7, p. 75-89, jan./jun. 2017.

COELHO, Mauro Cezar; MELO, Vinícius Zúniga. Os índios do Brasil em perspectiva histórica: possibilidades de trabalhar a História Indígena em sala de aula. In: COELHO, Wilma de Nazaré Baía et al (orgs.). A Diversidade em discussão: inclusão, ações afirmativas, formação e práticas docentes. São Paulo: Livraria da Física, 2016.

COELHO, Mauro Cezar; COELHO, Wilma de Nazaré Baía. A lei nº 10.639/03 e consciência histórica: ensino de História e os desafios da Diversidade. In: SIMPÓSIO NACIONAL DE HISTÓRIA, 27., 2013, Natal. Disponível em http://www.snh2013.anpuh.org/resources/anais/27/1364074796_ARQUIVO_TE XTOANPUH-NATAL2013-MAUROCEZARCOELHOEWILMABAIACOELHO.pdf. Acesso em 15 de jul. 2019.

FREIRE, José Ribamar Bessa. Cinco ideias equivocadas sobre os índios. Disponível em http://www.educadores.diaadia.pr.gov.br/arquivos/File/pdf/cinco_ideias_equivocadas_j ose_ribamar.pdf. Acesso em 22 de jul. 2019.

FUNDAÇÃO NACIONAL DO ÍNDIO - FUNAI. Disponível em http://www.funai.gov.br/. Acesso em 18 de jul. 2019.

GUIMARÃES, Manoel Luiz Salgado. Nação e Civilização nos Trópicos: O Instituto Histórico e Geográfico Brasileiro e o projeto de uma História Nacional. Estudos Históricos, Rio de Janeiro, v. 1, n. 1, p. 5-27, 1988.

ÍNDIO E INDÍGENA - MEKUKRADJÁ (2018). Itáu Cultural. São Paulo: Itaú Cultural, 2018. Disponível em https://www.youtube.com/watch?v=s39FxY3JziE. Acesso em 22 de jul. 2019.

LUCIANO, Gersem dos Santos (Baniwa). O Índio Brasileiro: o que você precisa saber sobre os povos indígenas no Brasil de hoje. Brasília: MEC/ UNESCO, 2006.

OLIVEIRA, Susane Rodrigues. Ensino de História indígena: trabalhando com narrativas coloniais e representações sociais. In: PORTUGAL, AR.; HURTADO, LR., orgs. Representações culturais da América indígena. São Paulo: Editora UNESP; São Paulo: Cultura Acadêmica, 2015, pp. 59-80.

PÁTARO, Ricardo Fernandes; PÁTARO, Cristina Satiê de Oliveira. Ensino de História e cultura indígena: reflexões a partir da estratégia de projetos em uma perspectiva transversal. In: SEMINÁRIO DE PESQUISA EM EDUCAÇÃO DA REGIÃO SUL, 9., 2012, Caxias do Sul. Disponível em http://www.ucs.br/etc/conferencias/index.php/anpedsul/9anpedsul/paper/viewFile/2028/ 413. Acesso em 12 de jul. 2019.

PATTÉ, Ana Roberta Uglõ, et al. (orgs.). Quebrando preconceitos, construindo respeito: luta e resistência dos povos indígenas no Brasil. Porto Alegre: Conselho de Missão entre Povos Indígenas: Fundação Luterana de Diaconia, 2019. 
POVOS INDÍGENAS NO BRASIL. Instituto Socioambiental. Disponível em https://pib.socioambiental.org/pt/P\%C3\%A1gina_principal. Acesso em 18 de jul. 2019.

REIS, Sandra Daniel Lozano Vera Sanchez; CAMPOS JÚNIOR, Luis de Castro. Novo olhar sobre o ensino de história indígena. In: PARANÁ (Estado). Secretaria da Educação. Cadernos PDE - Os desafios da Escola Pública Paranaense na perspectiva do professor PDE. Curitiba, 2016.

SANTILLI, Paulo. Povos indígenas e práticas de ensino no Brasil. In: SÃO PAULO (Estado). Secretaria da Educação. Cadernos de Formação do Estado de São Paulo ensino de História. São Paulo, 2006, p. 57-63.

SILVA, Edson. O ensino de História Indígena: possibilidades, exigências e desafios com base na Lei 11.645/2008. Revista História Hoje, São Paulo, v. 1, n. 2, p. 213-223, 2012.

. Povos indígenas e ensino de História: subsídios para a abordagem da temática indígena em sala de aula. História \& Ensino, Londrina. v. 8, p. 45-63, out. 2002.

TEAO, Kalna Mareto. Ensino de História Indígena: algumas reflexões. In:

CONGRESSO INTERNACIONAL UFES/PARIS-EST, 6., 2017, Vitória. Anais.... Vitória: Universidade Federal do Espírito Santo, 2017. p. 633-643.

VON MARTIUS, Karl Friederich Phillipe. Como se deve escrever a história do Brasil. In: GUIMARÃES, Manoel Luiz Salgado (orgs.). Livro de fontes de historiografia brasileira. Rio de Janeiro, EDUERJ, 2010. 


\title{
PRINCIPAIS POLÍTICAS PÚBLICAS NACIONAIS VOLTADAS PARA A INCLUSÃO EDUCACIONAL DO DEFICIENTE MENTAL NO BRASIL: Uma revisão
}

\author{
BARINI, Cristiane Rodrigues da Cunha \\ Mestranda - Uni-FACEF \\ cr_cunha@yahoo.com.br \\ CUNHA, Luísa Alves Rodrigues da \\ Docente da Faculdade de Direito - Uniube \\ luisaarcunha@hotmail.com \\ OLIVEIRA, Paulo de Tarso \\ Docente - Uni-FACEF \\ ptarsoliveira@gmail.com
}

\section{INTRODUÇÃO}

No final do século XIX, prevalecia o paradigma da institucionalização da deficiência mental e da absoluta exclusão educacional. As pessoas com deficiência e doença mental eram internadas em asilos e manicômios para tratamento, sem qualquer atividade de caráter pedagógico ou educacional, e não estavam inseridas em nenhum tipo de instituição de ensino.

A partir do século $X X$, surgiu, então, o movimento de desinstitucionalização do deficiente mental, fundamentado nas inadequações e ineficiências do cuidado institucional no processo de recuperação desses indivíduos. A ideia da época era ofertar um número de serviços variados que visassem a sua habilitação e/ou reabilitação, para garantir a sua participação social. No campo educacional, foram criadas escolas especiais e organizações e oficinas especializadas para a educação especial, caracterizando, assim, a integração escolar. (LEITE; MARTINS, 2015).

Num momento posterior, o conceito mais moderno de integração inseriu os alunos com deficiências e transtornos mentais em classes especiais dentro das escolas comuns, para atendimento educacional especializado.

Como alerta Leite e Martins (2015), a integração do deficiente mental peca pois enfatiza a condição de deficiente do indivíduo, desconsiderando o fato de que a diferença faz parte da constituição humana.

Seguindo o processo de evolução, o pensamento inclusivo surgiu, oficialmente, com a Declaração de Salamanca (1994). Porém, entre os anos de 1994 e 2003, evidenciou-se certa confusão entre os conceitos de inclusão e integração, na medida em que os atos normativos emanados, em um primeiro momento, universalizavam o acesso aos sistemas de ensino, mas, em seguida, 
continuavam segregando as crianças que não se encontram dentro dos padrões homogêneos da escola.

O processo de inclusão, objetivado na atualidade, parte do reconhecimento da diversidade como integrante de todos os segmentos populacionais. Na inclusão, a sociedade assume maior responsabilidade, pois deve se organizar para permitir e promover o desenvolvimento de todo e qualquer cidadão, garantindo condições para a sua participação efetiva (SANTANA; NUNES, 2018).

Nessa perspectiva, considerando o processo de evolução da educação especial no Brasil, o presente trabalho visa levantar as principais políticas públicas de âmbito nacional, voltadas para a inclusão de alunos com deficiência ou distúrbio mental.

O presente artigo é o resultado de uma pesquisa de abordagem qualitativa, pois se preocupa com um nível de realidade que não pode ser quantificado, e, por isso, não se fixa ao estabelecimento de médias ou estatísticas. Possui natureza aplicada, já que visa gerar conhecimentos para aplicação prática, dirigidos à solução de problemas específicos, envolvendo verdades e interesses locais. (GERHARDT; SILVEIRA, 2009). É classificada, quanto aos objetivos, como uma pesquisa exploratória, já que tem como objetivo proporcionar maior familiaridade com o problema, com vistas a torná-lo mais explícito ou a construir hipóteses (GIL, 2007). Esta pesquisa envolve unicamente levantamento bibliográfico, feito a partir do levantamento de referências teóricas publicadas por meios escritos e eletrônicos, como livros, artigos científicos, páginas de web sites, e outros, embasado nos ensinamentos de Fonseca:

\footnotetext{
"Existem, porém, pesquisas científicas que se baseiam unicamente na pesquisa bibliográfica, procurando referências teóricas publicadas com o objetivo de recolher informações ou conhecimentos prévios sobre o problema a respeito do qual se procura a resposta (FONSECA, 2002, p. 32).
}

\section{PRINCIPAIS POLÍTICAS PÚBLICAS NACIONAIS VOLTADAS PARA A INCLUSÃO EDUCACIONAL DO DEFICIENTE MENTAL NO BRASIL}

Historicamente, a escola se caracterizou pela visão da educação que delimitava a escolarização como privilégio de um grupo seleto, uma exclusão legitimada pelas políticas e práticas educacionais reprodutoras da ordem social (BRASIL, 2008).

A educação especial dirigida a alunos com deficiências mentais se organizou tradicionalmente como atendimento educacional especializado, substitutivo do ensino comum da escola regular, evidenciando diferentes compreensões, terminologias e modalidades que levaram a criação de 
instituições especializadas, escolas especiais e classes especiais. (BRASIL, 2008) Havia uma organização que separava os alunos com base no conceito de normalidade versus anormalidade.

Dois relevantes trabalhos fizeram nascer, no início do século XX, uma estreita relação entre a psiquiatria infantil, a deficiência mental, a psicologia e a pedagogia, evidenciando a importância de uma atuação integrada e multiprofissional. O primeiro deles foi a criação do Instituto Pestalozzi, voltado para os cuidados de crianças deficientes mentais, no ano de 1929, em Minas Gerais, por Helena Antipoff. O outro foi a constituição do Instituto de Psicologia, em Pernambuco, no ano de 1925, por Ulysses Pernambucano. Essa instituição foi se aperfeiçoando na atuação com crianças deficientes e, em 1929, foi montada uma equipe multiprofissional para atuar no desenvolvimento completo desses indivíduos. (RIBEIRO, 2006, p. 34).

Dessa forma, a educação desse segmento populacional passou a ser desempenhada por entidades da sociedade civil, sem fins lucrativos, que prestavam serviço de natureza pública, como os exemplificados acima. Em 1954 foi fundada a primeira Associação de Pais e Amigos dos Excepcionais APAE.

Com as políticas públicas e normas inclusivas editadas, deu-se o processo de democratização da escola, permitindo o acesso de crianças portadoras de transtornos mentais no ensino regular.

Em 1961, foi publicada a Lei 4.024/61, que fixou as Diretrizes e Bases da Educação Nacional. Este diploma normativo previa que educação de "excepcionais", devia, sempre que possível, enquadrar-se no sistema geral de educação, a fim de integrá-los na comunidade. (BRASIL, 1961)

Esta lei sofreu alteração pela Lei №. 5.692/71, que conferiu, no artigo $9^{\circ}$, "tratamento especial"' aos alunos com "deficiências físicas, mentais, os que se encontrem em atraso considerável quanto à idade regular de matrícula e os superdotados" (BRASIL, 1971).

Esta alteração não promoveu a organização de um sistema de ensino capaz de atender as necessidades educacionais especiais, mas, sim, acabou reforçando o encaminhamento dos alunos deficientes para as classes e escolas especiais (BRASIL, 2008).

O País ficou, por alguns anos, sem qualquer política pública efetiva de acesso universal à educação, conservando o paradigma de políticas especiais para tratar da educação de alunos com deficiência.

A Constituição Federal, promulgada em 1988, trouxe diversos dispositivos que relacionam a educação com a igualdade entre os indivíduos, repudiando o preconceito e a discriminação. Em seu artigo $3^{\circ}$, inciso IV, traça como um dos seus objetivos fundamentais, a promoção do bem de todos, sem 
preconceitos de origem, raça, sexo, cor, idade e quaisquer outras formas de discriminação; No artigo 205, define a educação como um direito de todos, garantindo o pleno desenvolvimento da pessoa, o exercício da cidadania e a qualificação para o trabalho. No artigo 206, inciso I, estabelece a igualdade de condições de acesso e permanência na escola como um dos princípios para o ensino, e, no artigo 208, inciso III, impõe ao Estado o dever de garantir atendimento educacional especializado aos portadores de deficiência, preferencialmente na rede regular de ensino (BRASIL, 1988).

Na sequência, entrou em vigor a Lei $n^{0} 7.853$, de 24 de outubro de 1989, com vistas a estabelecer normas gerais que assegurassem o pleno exercício dos direitos individuais e sociais das pessoas portadoras de deficiências, e sua efetiva integração social. Especificamente na área da educação, determinou a inclusão, no sistema educacional, da Educação Especial como modalidade educativa e a inserção, no referido sistema educacional, das escolas especiais, privadas e públicas. Nada obstante, esta lei (artigo $2^{\circ}$, parágrafo único, inciso I) permitiu o acesso à escola comum apenas de alunos com deficiência que fossem capazes de se integrar no sistema regular de ensino (BRASIL, 1989).

O Estatuto da Criança e do Adolescente, Lei nº. 8.069/90, determinou o dever dos pais ou responsáveis de matricular seus filhos ou pupilos na rede regular de ensino. Também, nessa década, documentos como a Declaração Mundial de Educação para Todos (1990) e a Declaração de Salamanca (1994), que dispõe sobre princípios, políticas e práticas na área das necessidades educacionais especiais, passaram a influenciar a formulação das políticas públicas da educação inclusiva. (BRASIL, 2008)

Aliás, como aponta Vargas e Schmidt (2017), a Declaração de Salamanca (1994) é considerada uma referência histórica na organização e implementação de políticas públicas para a promoção da inclusão escolar. É o primeiro documento oficial a expressamente prever a possibilidade de que crianças com deficiência tivessem acesso à escola comum, e não mais aos espaços considerados segregados, o que provocou questões e discussões em torno da definição do atendimento a esse público. (NEVES; RAHME; FERREIRA, 2019)

O princípio fundamental da escola inclusiva, segundo este diploma normativo, é o de que todas as crianças devem aprender juntas, sempre que possível, independentemente de quaisquer dificuldades ou diferenças que elas possam ter. (UNESCO, 1994)

Com esse entendimento,

"Escolas inclusivas devem reconhecer e responder às necessidades diversas de seus alunos, acomodando ambos os estilos e ritmos de aprendizagem e assegurando uma educação de qualidade à todos através de um currículo apropriado, arranjos organizacionais, 
estratégias de ensino, uso de recurso e parceria com as comunidades." (UNESCO, 1994)

Ressalte-se que o termo necessidades educacionais especiais foi introduzido no ordenamento jurídico pela Declaração de Salamanca (1994) e "refere-se a todas aquelas crianças ou jovens cujas necessidades educacionais especiais se originam em função de deficiências ou dificuldades de aprendizagem". (UNESCO, 1994)

Importante registrar que muitas crianças experimentam dificuldades de aprendizagem, carecendo de necessidades educacionais especiais em algum ponto durante a sua escolarização. Porém, nem todas apresentam deficiências mentais. (ALVES, 2019, p. 9)

Em 1994, foi publicada a Política Nacional de Educação Especial que, em movimento oposto ao da inclusão, condicionava o acesso às classes comuns do ensino regular àqueles que possuírem condições de acompanhar e desenvolver as atividades curriculares programadas do ensino comum, no mesmo ritmo que os alunos ditos normais. (BRASIL, 2008)

Dois anos depois, foi editada a Lei de Diretrizes e Bases da Educação Nacional (LDB), Lei no 9.394, de 20 de dezembro de 1996. Ainda em vigor, esta lei foi alterada pela Lei oㅜ 12.796, de 2013, e passou a dispor, em seu artigo 4ํ․ III, que o dever do Estado com educação escolar pública será efetivado, também, mediante atendimento educacional especializado gratuito aos educandos com deficiência, transtornos globais do desenvolvimento e altas habilidades ou superdotação, transversal a todos os níveis, etapas e modalidades, preferencialmente na rede regular de ensino. (BRASIL, 1996)

Além disso, a LDB, em seu artigo $58, \S \S 1^{\circ}$ e $2^{\circ}$, garantiu a atuação de serviços de apoio especializado na escola regular, para atender às peculiaridades da clientela de educação especial, quando necessário, e estabeleceu que $o$ atendimento educacional será feito em classes, escolas ou serviços especializados, sempre que, em função das condições específicas dos alunos, não for possível a sua integração nas classes comuns de ensino regular. (BRASIL, 1996)

Dentre outras disposições, a LDB ainda determinou, no artigo 59, incisos I, II e III, que os sistemas de ensino deveriam assegurar aos educandos com deficiência e transtornos globais do desenvolvimento currículos, métodos, técnicas, recursos educativos e organização específicos, para atender às suas necessidades, e terminalidade específica para aqueles que não puderem atingir o nível exigido para a conclusão do ensino fundamental, em virtude de suas deficiências; professores com especialização adequada em nível médio ou superior, para atendimento especializado, bem como professores do ensino 
regular capacitados para a integração desses educandos nas classes comuns (BRASIL, 1996).

Em 20 de dezembro de 1999, entrou em vigor o Decreto ํㅡ 3.298, para regulamentar a Lei no 7.853/89, estabelecendo a Política Nacional para a Integração da Pessoa Portadora de Deficiência, mediante a fixação do conjunto de orientações normativas que objetivavam assegurar o pleno exercício dos direitos individuais e sociais das pessoas portadoras de deficiência. Como se trata de ato regulamentador, não trouxe nenhuma inovação normativa em relação aos comandos da Lei 7.853/89, apenas reforçou o sistema educacional tradicional, permitindo acesso ao ensino regular apenas aos deficientes que demonstrassem capacidade, mantendo a educação especial destinada aos demais deficientes mentais. (BRASIL, 1999)

As Diretrizes Nacionais para a Educação Especial na Educação Básica, elaboradas por meio da Resolução CNE/CEB nํ2/2001, no artigo 2ํㅡㄴ, determina aos sistemas de ensino a matrícula obrigatória de todos os alunos, impondo às escolas o encargo de se organizar para o atendimento aos educandos com necessidades educacionais especiais, assegurando as condições necessárias para uma educação de qualidade para todos. (MEC/SEESP, 2001).

No artigo 3ํa a Resolução enquadra a educação especial como modalidade da educação escolar, e a define como um processo educacional caracterizado por uma proposta pedagógica que assegure recursos e serviços educacionais especiais, organizados institucionalmente para apoiar, complementar, suplementar e, em alguns casos, substituir os serviços educacionais comuns, de modo a garantir a educação escolar e promover o desenvolvimento das potencialidades dos educandos que apresentam necessidades educacionais especiais, em todas as etapas e modalidades da educação básica. (MEC/SEESP, 2001).

Ressalte-se que as Diretrizes ampliaram o caráter da educação especial para realizar o atendimento educacional especializado complementar ou suplementar a escolarização, porém, ao admitir a possibilidade de substituir o ensino regular, não potencializou a adoção de uma política de educação inclusiva na rede pública de ensino prevista no seu artigo $2^{\circ}$ (BRASIL, 2008).

A Lei 10.172, de 9 de janeiro de 2001, aprovou o Plano Nacional de Educação, com duração de dez anos, com objetivo maior de instituir, dentro da década de vigência, uma escola inclusiva, que garantisse o atendimento à diversidade humana.

O diagnóstico realizado da educação especial em 2001 apontou para o seguinte resultado:

"Apesar do crescimento das matrículas, o déficit é muito grande e constitui um desafio imenso para os sistemas de ensino, pois 
diversas ações devem ser realizadas ao mesmo tempo. Entre elas, destacam-se a sensibilização dos demais alunos e da comunidade em geral para a integração, as adaptações curriculares, a qualificação dos professores para 0 atendimento nas escolas regulares e a especialização dos professores para o atendimento nas novas escolas especiais, produção de livros e materiais pedagógicos adequados para as diferentes necessidades, adaptação das escolas para que os alunos especiais possam nelas transitar, oferta de transporte escolar adaptado, etc." (BRASIL, 2001)

A Convenção da Guatemala, de 28 de maio de 1999, ratificada pelo Brasil por meio do Decreto $n . .93 .956$, de 08 de outubro de 2001, reafirmou que as pessoas com deficiência têm os mesmos direitos humanos e liberdades fundamentais que as demais pessoas, inclusive o direito de não ser submetidas a discriminação com base na deficiência, emanam da dignidade e da igualdade que são inerentes a todo ser humano. (BRASIL, 2001)

\begin{abstract}
"Esse Decreto tem importante repercussão na educação, exigindo uma reinterpretação da educação especial, compreendida no contexto da diferenciação adotada para promover a eliminação das barreiras que impedem o acesso à escolarização". (BRASIL, 2008, online)
\end{abstract}

O Conselho Nacional de Educação, mediante a Resolução CNE/CP 1, de 18 de fevereiro de 2002, instituiu Diretrizes Curriculares Nacionais para a Formação de Professores da Educação Básica, em nível superior, curso de licenciatura, de graduação plena. Este documento normativo formula um conjunto de princípios, fundamentos e procedimentos a serem observados na organização institucional e curricular de cada estabelecimento de ensino e aplicam-se a todas as etapas e modalidades da educação básica (artigo $1^{\circ}$ ). No que tange à educação inclusiva, impõe às instituições de ensino superior o oferecimento de uma formação docente voltada para a atenção à diversidade e que contemple conhecimentos sobre as especificidades dos

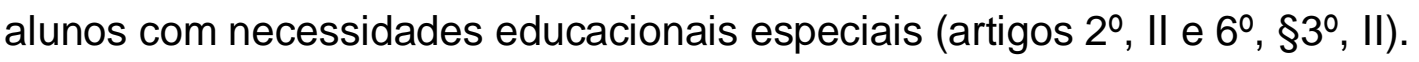

Em 2003, o Ministério da Educação criou o Programa Educação Inclusiva: direito à diversidade, com objetivo de transformar os sistemas de ensino em sistemas educacionais inclusivos. Este programa promoveu um amplo processo de formação de gestores e educadores nos municípios brasileiros para a garantia do direito de acesso de todos à escolarização, a organização do atendimento educacional especializado e a promoção da acessibilidade. (BRASIL, 2008)

Dessa maneira, a partir de 2003, o Brasil passou a adotar direcionamentos na gestão de sua política educacional, priorizando a matrícula dos estudantes portadores de necessidades especiais em salas comuns de escolas públicas, com acompanhamento ou não de atendimentos especializados. (NEVES; RAHME; FERREIRA, 2019) 
Em 2004, o Ministério Público Federal divulgou o documento 0 Acesso de Alunos com Deficiência às Escolas e Classes Comuns da Rede Regular, visando disseminar os conceitos e diretrizes mundiais para a inclusão, reafirmando o direito e os benefícios da escolarização de alunos com e sem deficiência nas turmas comuns do ensino regular. (BRASIL, 2008)

A Convenção sobre os Direitos das Pessoas com Deficiência, aprovada pela ONU em 2006, da qual o Brasil é signatário, dedica seu artigo 24 exclusivamente à educação. Para efetivar o direito das pessoas com deficiência à educação, sem discriminação e com base na igualdade de oportunidades, esse acordo impõe aos Estados Partes a implantação de um sistema educacional inclusivo em todos os níveis, com a admissão do aluno deficiente no sistema educacional geral, devendo oferecer o apoio necessário, com vistas a facilitar sua efetiva educação. Impõe também que as medidas de apoio individualizadas sejam adotadas em ambientes que maximizem 0 desenvolvimento acadêmico e social, de acordo com a meta de inclusão plena. (BRASIL, 2006)

Em 2006, a Secretaria Especial dos Direitos Humanos, o Ministério da Educação, o Ministério da Justiça e a UNESCO lançaram o Plano Nacional de Educação em Direitos Humanos que reafirmou o "dever dos governos democráticos garantir a educação de pessoas com necessidades especiais" e objetiva, dentre outras ações, "orientar políticas educacionais direcionadas para a constituição de uma cultura de direitos humanos", de maneira a promover a igualdade de oportunidades e a equidade, o respeito à diversidade e a consolidação de uma cultura democrática e cidadã. As ações elaboradas para alcançar os objetivos traçados pelo PNEDH incluem informar a população sobre educação em direitos humanos por diversos meios, de modo a sensibilizar a sociedade e garantir acessibilidade às pessoas com deficiências e fomentar a inclusão, no currículo escolar, das temáticas relativas pessoas com deficiências, entre outros, para combater todas as formas de discriminação e violações de direitos. (BRASIL, 2006)

Em abril de 2007, foi publicado o Decreto o 6.094/07, que institui o Plano de Metas Compromisso Todos pela Educação. Este documento propõe uma conjugação de esforços da União, Estados, Distrito Federal e Municípios, e das famílias e da comunidade, em proveito da melhoria da qualidade da educação básica, trazendo, como uma de suas diretrizes, a garantia do acesso e permanência das pessoas com necessidades educacionais especiais nas classes comuns do ensino regular, fortalecendo a inclusão educacional nas escolas públicas (BRASIL, 2007)

E, em janeiro de 2008, o Ministério da Educação, através da Secretaria de Educação Especial, apresentou o documento Política Nacional de Educação Especial na Perspectiva da Educação Inclusiva (PNEEPEI), resultado dos avanços do conhecimento e das lutas sociais, visando constituir 
políticas públicas promotoras de uma educação de qualidade para todos os alunos. (BRASIL, 2008)

Conforme análise de Vargas e Schmidt (2017), a Política Nacional de Educação Especial na Perspectiva da Educação Inclusiva deliberou sobre a estrutura e organização da inclusão escolar brasileira. Concebeu a Educação Especial não mais como um atendimento educacional especializado à parte, mas, sim, uma modalidade de ensino transversal a todos os níveis e modalidades de ensino da escola comum, inclusive definindo mais claramente seu público alvo.

Desse modo, esta Política inaugurou novo marco na educação brasileira, alocando a Educação Especial como modalidade de ensino não substitutiva à escolarização que perpassa todos os níveis, etapas e modalidades; e definindo seu público alvo, ou seja, os sujeitos com direito a essa modalidade. Nesse sentido, o Atendimento Educacional Especializado (AEE) complementar ou suplementar é visto como elo articulador, a ser garantido aos estudantes por meio da atuação de professores especializados, tempos, espaços e recursos adequados às necessidades específicas de cada sujeito que demande tal atendimento. (NEVES; RAHME; FERREIRA, 2019)

A Resolução no 4, de 2 de outubro de 2009 foi editada para a implementação do Decreto $n=6.571 / 2008$. Segundo este ato normativo, os sistemas de ensino devem matricular os alunos com deficiência, transtornos globais do desenvolvimento e altas habilidades/superdotação nas classes comuns do ensino regular e, de forma complementar ou suplementar, também no Atendimento Educacional Especializado (AEE). Esse atendimento deve ofertado em salas de recursos multifuncionais (SRM) ou em centros de Atendimento Educacional Especializado (AEE) da rede pública ou de instituições comunitárias, confessionais ou filantrópicas sem fins lucrativos. $O$ AEE opera por meio da disponibilização de serviços, recursos de acessibilidade e estratégias que eliminem as barreiras para sua plena participação na sociedade e desenvolvimento da aprendizagem do deficiente (BRASIL, 2009).

O Decreto Executivo no 7.611, de 17 de novembro de 2011, regulamenta os artigos 58 a 60 da Lei no 9.394, de 20 de dezembro de 1996, 0 artigo 9으 $\S 2^{\circ}$, da Lei no 11.494, de 20 de junho de 2007, o artigo 24 da Convenção sobre os Direitos das Pessoas com Deficiência e seu Protocolo Facultativo, aprovados por meio do Decreto Legislativo $n^{0} 186$, de 9 de julho de 2008, com status de emenda constitucional, e promulgados pelo Decreto $\mathrm{n}^{\mathrm{0}}$ 6.949, de 25 de agosto de 2009. Ele trata, dentre outros assuntos, das diretrizes e dos objetivos da Educação Especial no Brasil. De forma bem objetiva, firma que educação especial deve visar a eliminação das barreiras que possam obstruir o processo de escolarização de estudantes com deficiência, transtornos globais do desenvolvimento e altas habilidades ou 
superdotação, através de serviços de apoio especializado, denominados de atendimento educacional especializado. Esses serviços compreendem o conjunto de atividades, recursos de acessibilidade e recursos pedagógico, prestados para complementar à formação dos estudantes com deficiência e transtornos globais do desenvolvimento, como apoio permanente e limitado no tempo e na frequência dos estudantes às salas de recursos multifuncionais, ou suplementar à formação de estudantes com altas habilidades ou superdotação. Esse ato também revogou o Decreto executivo nำ6.571, de 17 de setembro de 2008.

Especificamente em relação aos portadores do Transtorno do

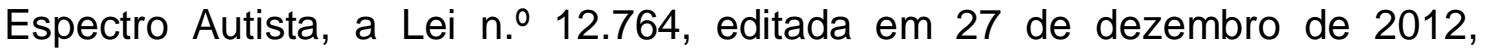
também chamada de Lei Berenice Piana, representa um marco na luta pelo reconhecimento e positivação dos direitos deste grupo. Ela institui a Política Nacional de Proteção dos Direitos da Pessoa com Transtorno do Espectro Autista e firma direitos e traça diretrizes gerais para a instituições de medidas relativas aos portadores de TEA. (BRASIL, 2013)

Em seu artigo 3ㅜㅡ, a Lei $n .012 .764 / 12$ estabelece direitos a que fazem jus os portadores de transtorno do espectro autista, incluindo no rol, expressamente, a educação em instituição de ensino regular ou especial (BRASIL, 2012).

A Lei no 12.796 , de 4 de abril de 2013, deu nova redação ao artigo 4는, III, da Lei n 9.394, de 20 de dezembro de 1996, passando a determinar que o dever do Estado com educação escolar pública será efetivado mediante a garantia de atendimento educacional especializado gratuito aos educandos com transtornos globais do desenvolvimento, transversal a todos os níveis, etapas e modalidades, preferencialmente na rede regular de ensino. (BRASIL, 1996)

Desde 25 de junho de 2014, vige a Lei no 13.005, que aprovou o Plano Nacional de Educação - PNE, com vigência por 10 (dez) anos, com metas e estratégias estabelecidas voltadas para a inclusão das pessoas com deficiência no ensino regular.

No início do ano de 2016, entrou em vigor a Lei no 13.146, de 6 de julho de 2015, que instituiu a Lei Brasileira de Inclusão da Pessoa com Deficiência, conhecida por Estatuto da Pessoa com Deficiência, destinada a assegurar e a promover, em condições de igualdade, o exercício dos direitos e das liberdades fundamentais por pessoa com deficiência, visando à sua inclusão social e cidadania (BRASIL, 2015).

Em relação a educação, o Estatuto da Pessoa com Deficiência inovou, atribuindo também às instituições privadas, de qualquer nível e modalidade de ensino, a obrigação de promover, por todos meios, a inclusão das pessoas com necessidades educacionais especiais, inclusive com 
deficiência mental ou transtornos de neurodesenvolvimento. Assim, a escola privada passou a ter o dever de oferecer, dentre outros serviços e programas, 0 atendimento educacional especializado, e outros serviços e adaptações razoáveis, para atender às características dos estudantes com deficiência; a adoção de práticas pedagógicas inclusivas pelos programas de formação inicial e continuada de professores e oferta de formação continuada para 0 atendimento educacional especializado; a formação e disponibilização de professores para 0 atendimento educacional especializado e de profissionais de apoio, inclusive na área da educação física. O objetivo é garantir o pleno acesso ao portadores de necessidades especiais ao currículo e às atividades recreativas, esportivas e de lazer em condições de igualdade, promovendo a conquista e o exercício de sua autonomia. O Estatuto da Pessoa com Deficiência ainda vedou expressamente a cobrança de valores adicionais de qualquer natureza em suas mensalidades, anuidades e matrículas no cumprimento dessas determinações.

Em 28 de dezembro de 2016, foi publicada a Lei no 13.409, que alterou a Lei no 12.711/12, para determinar a reserva de vagas para pessoas com deficiência nos cursos técnico de nível médio e superior das instituições federais de ensino.

Em 2016, o Ministério da Educação elaborou um dossiê, intitulado de A Consolidação da Inclusão Escolar no Brasil, composto de documentos, como notas técnicas e pareceres, decretos e resoluções, com o intuito de "subsidiar as discussões, ações e o controle social das políticas públicas voltadas à inclusão escolar das pessoas com deficiência, transtornos globais do desenvolvimento e altas habilidades/superdotação" (BRASIL, 2016).

Não se trata exatamente de uma política pública, mas traz dados relevantes acerca das medidas adotadas sobre o tema no Brasil, no período de 2003 a 2016. O dossiê, além de outras informações, arrola o conjunto de ações e programas de apoio ao desenvolvimento inclusivo dos sistemas de ensino, que foram implantadas no país, neste lapso temporal, a saber: Programa de Formação Continuada de Professores em Educação Especial; Programa Educação Inclusiva: direito à diversidade; Programa Implantação de Salas de Recursos Multifuncionais; Programa Escola Acessível; Programa BPC na Escola; Transporte Escolar Acessível; Projeto Livro Acessível; Centros de Formação e Recursos - CAP, CAS e NAAH/S; Projeto Sistema FM; Prêmio Experiências Educacionais Inclusivas: a escola aprendendo com as diferenças; Educação Bilíngue - formação de professores, intérpretes e tradutores da Língua Brasileira de Sinais; PROLIBRAS - Programa Nacional para a Certificação de Proficiência no Uso e Ensino da Língua Brasileira de Sinais LIBRAS e para a Certificação de Proficiência em Tradução e Interpretação da LIBRAS/Língua Portuguesa; Programa INCLUIR - Acessibilidade na Educação Superior; PROESP - Programa de Apoio à Pesquisa em Educação Especial; 
Projeto Escola de Todos; Projetos OEI - Organização dos Estados IberoAmericanos para a Educação a Ciência e a Cultura; Projetos UNESCO Organização das Nações Unidas para a Ciência, a Educação e a Cultura; e Publicações de referenciais para subsidiar a implementação da Política Nacional de Educação Especial na Perspectiva da Educação Inclusiva, disponíveis no Portal do Ministério da Educação (BRASIL, 2016).

\section{CONSIDERAÇÕES FINAIS}

Desde o final do século, XIX, o processo de evolução da educação especial, no país, permeou pelas fases da segregação e da integração, para aportar na ideologia da inclusão educacional dos deficientes mentais.

No Brasil, passaram pelo ordenamento jurídico diversas Leis, Resoluções, Decretos e Orientações acerca da inclusão educacional desse segmento populacional. Esse trabalho colecionou as principais políticas públicas de âmbito nacional, voltadas para a inclusão desses alunos na escola regular.

O que se visa na política educacional atual é a completa inclusão da criança com deficiência. $O$ ensino inclusivo reconhece que todas as crianças são diferentes e cada uma tem sua peculiaridade no aprendizado, e impõe às escolas e aos sistemas de educação sua adequação e transformação para atender às necessidades individuais de todos os educandos. Para tanto, exige a utilização de diferentes métodos para se responder às variadas necessidades, capacidades e níveis de desenvolvimento individuais.

Nada obstante, a concretização do ideal inclusivo está longe de ser alcançado, pois precisa superar grandes desafios de diversas ordens, tais como a adequação do espaço físico, a escassez de recursos financeiros, a escassez de recursos materiais e técnico-especializados de apoio nos entes públicos, a conscientização e cooperação da sociedade, a falta de professores especializados ou capacitados, que dificultam sobremaneira sua real implementação.

\section{REFERÊNCIAS}

ALVES, Everton Ucela. Políticas Públicas de Educação Inclusiva: O posicionamento dos docentes de Santo André - Brasil. Porto: Universidade Fernando Pessoa, 2019. 114f. Dissertação (Mestrado). Programa de Mestrado em Ciências da Educação - Educação Especial. Universidade Fernando Pessoa, Porto, 2019. Disponível em $<$ https://bdigital.ufp.pt/bitstream/10284/7739/1/DM Everton\%20Ucela\%20Alves .pdf >. Acesso em 19 jul. 2019. 
BRASIL. Constituição da República Federativa do Brasil de 1988. Disponível em:

$<$ http://www.planalto.gov.br/ccivil 03/constituicao/ConstituicaoCompilado.htm>. Acesso em 05 jul. 2019.

. Comitê Nacional de Educação em Direitos Humanos. Plano Nacional de Educação em Direitos Humanos. Brasília: Secretaria Especial dos Direitos Humanos, Ministério da Educação, Ministério da Justiça, UNESCO, 2007. Disponível em <http://portal.mec.gov.br/docman/2191-plano-nacional-pdf/file $>$. Acesso em 16 jul. 2019.

. Conselho Nacional de Educação. Resolução CNE/CP 1, de 18 de fevereiro de 2002. Disponível em $<$ http://portal.mec.gov.br/seesp/arquivos/pdf/res1 2.pdf >. Acesso em 16 jul. 2019.

. Decreto nํ 3.298, de 20 de dezembro de 1999. Disponível em $<$ http://www.planalto.gov.br/ccivil 03/decreto/d3298.htm>. Acesso em 16 jul. 2019.

. Decreto no 3.956 de 08 de Outubro de 2001. Ratifica a Convenção da Guatemala, de 28 de maio de 1999. Disponível em <http://www.faders.rs.gov.br/legislacao/6/29 >. Acesso em 16 jul. 2019.

. Decreto nํ 6.094, de 24 de abril de 2007. Disponível em <http://www.planalto.gov.br/ccivil 03/ ato2007-2010/2007/decreto/d6094.htm>. Acesso em 16 jul. 2019.

. Decreto $n^{\circ} 7.611$, de 17 de novembro de 2011. Dispõe sobre a educação especial, o atendimento educacional especializado e dá outras providências. Disponível em < http://www.planalto.gov.br/ccivil 03/ Ato20112014/2011/Decreto/D7611.htm\#art11>. Acesso em 24 jul. 2019.

. Lei n. 10.172, de 9 de janeiro de 2001. Aprova o Plano Nacional de Educação e dá outras providências. Disponível em $<$ http://www.planalto.gov.br/ccivil 03/leis/leis 2001//10172.htm>. Acesso em 16 jul. 2019.

. Lei n.10.172, de 9 de janeiro de 2001. Aprova o Plano Nacional de Educação e dá outras providências. Disponível em $<$ http://www.planalto.gov.br/ccivil 03/leis/leis 2001//10172.htm>. Acesso em 16 jul. 2019.

. Lei no 13.005, de 25 de junho de 2014. Aprova o Plano Nacional de Educação - PNE e dá outras providências. Disponível em $<$ http://www.planalto.gov.br/ccivil 03/ ato2011-2014/2014/lei/l13005.htm>. Acesso em 24 jul. 2019.

. Lei $\mathrm{n}^{\circ}$ 13.146, de 6 de julho de 2015. Institui a Lei Brasileira de Inclusão da Pessoa com Deficiência (Estatuto da Pessoa com Deficiência). 
Disponível em <http://www.planalto.gov.br/ccivil 03/ ato20152018/2015/lei//13146.htm>. Acesso em 24 jul. 2019.

. Lei oㅜ 13.409, de 28 de dezembro de 2016. Altera a Lei oㅜ 12.711, de 29 de agosto de 2012. Disponível em $<$ http://www.planalto.gov.br/ccivil 03/ Ato2015-2018/2016/Lei/L13409.htm>. Acesso em 24 jul. 2019.

. Lei no 4.024, de 20 de dezembro de 1961. Disponível em $<$ http://www.planalto.gov.br/ccivil 03/LEIS/L4024.htm>. Acesso em 16 jul. 2019.

. Lei no 5.692, de 11 de agosto de 1971. Disponível em $<$ https://presrepublica.jusbrasil.com.br/legislacao/128525/lei-de-diretrizes-ebase-de-1971-lei-5692-71>. Acesso em 16 jul. 2019.

. Lei no 7.853, de 24 de outubro de 1989. Disponível em <http://www.planalto.gov.br/ccivil 03/leis/L7853.htm>. Acesso em 16 jul. 2019.

. Lei no 9.394, de 20 de dezembro de 1996. Disponível em $<$ http://www.planalto.gov.br/ccivil 03/leis/19394.htm>. Acesso em 16 jul. 2019.

. Ministério da Educação e Cultura. Política Nacional de Educação Especial na Perspectiva da Educação Inclusiva. Disponível em $<$ http://portal.mec.gov.br/arquivos/pdf/politicaeducespecial.pdf $>$. Acesso em 16 jul. 2019.

. Ministério da Educação. Resolução no 4, de 2 de outubro de 2009. Institui Diretrizes Operacionais para o Atendimento Educacional Especializado na Educação Básica, modalidade Educação Especial. Disponível em $<$ http://portal.mec.gov.br/dmdocuments/rceb004 09.pdf $>$. Acesso em 19 jul. 2019.

Resolução CNE/CEB № 2, de 11 de setembro de 2001. Institui Diretrizes Nacionais para a Educação Especial na Educação Básica. Disponível em <http://portal.mec.gov.br/cne/arquivos/pdf/CEB0201.pdf>. Acesso em 16 jul. 2019.

. Secretaria Especial dos Direitos Humanos. Convenção sobre os Direitos das Pessoas com Deficiência. Disponível em $<$ http://portal.mec.gov.br/index.php?option=com docman\&view=download\&alia $\mathrm{s}=424$-cartilha-c\&category slug=documentos-pdf\&ltemid=30192 $>$. Acesso em 16 jul. 2019.

FONSECA, J. J. S. Metodologia da pesquisa científica. Fortaleza: UEC, 2002. Apostila.

FONSECA, J. J. S. Metodologia da pesquisa científica. Fortaleza: UEC, 2002. Apostila. Disponível em $<$ https://books.google.com.br/books?id=oB5x2SChpSEC\&printsec=frontcover\& 
$\mathrm{hl}=\mathrm{pt}-\mathrm{BR} \&$ source=gbs ge summary $\mathrm{r} \& \mathrm{cad}=0 \# \mathrm{v}=$ onepage \&q\&f=false$>$. Acesso em 25 jul. 2019.

GERHARDT, Tatiana Engel; SILVEIRA, Denise Tolfo (organizadoras). Métodos de pesquisa. Coordenado pela Universidade Aberta do Brasil - UAB/UFRGS e pelo Curso de Graduação Tecnológica - Planejamento e Gestão para o Desenvolvimento Rural da SEAD/UFRGS. - Porto Alegre: Editora da UFRGS, 2009. Disponível em $<$ http://www.ufrgs.br/cursopgdr/downloadsSerie/derad005.pdf > Acesso em 13 de maio 2019.

GIL, A. C. Como elaborar projetos de pesquisa. 4. ed. São Paulo: Atlas, 2007.

LEITE, Lúcia Pereira; MARTINS, Sandra Eli Sartoreto de Oliveira. A educação especial em tempos de educação inclusiva: dos aportes normativos aos aspectos operacionais. In: DAVID, CM., et al., orgs. Desafios contemporâneos da educação [online]. São Paulo: Editora UNESP; São Paulo: Cultura Acadêmica, p. 85-105, 2015. ISBN 978-85-7983-622-0. SciELO Books. Disponível em <http://books.scielo.org/id/zt9xy/pdf/david9788579836220-06.pdf> Acesso em 20 de jul. 2019.

NEVES, Libéria Rodrigues; RAHME, Mônica Maria Farid; FERREIRA, Carla Mercês da Rocha Jatobá. Política de Educação Especial e os Desafios de uma Perspectiva Inclusiva. Educ. Real., Porto Alegre , v. 44, n. 1, 07 de Março, 2019. Disponível em $<$ http://www.scielo.br/scielo.php?script=sci arttext\&pid=S217562362019000100203\&lng=en\&nrm=iso\#B25>. Acesso em 20 Jul. 2019.

RIBEIRO, Paulo Rennes Marçal. História da Saúde Mental Infantil: A Criança Brasileira da Colônia à República Velha. Psicologia em Estudo, Maringá, v. 11, n. 1, p. 29-38, jan./abr. 2006. Disponível em $<$ http://www.scielo.br/pdf/pe/v11n1/v11n1a04.pdf >. Acesso em 13 jul. 2019.

SANTANA, lolamárcia Quinto de Souza; NUNES, Doutora Isabel Matos. Educação Especial e Inclusão: As Políticas Públicas Brasileiras de Inclusão de Pessoas Público-Alvo da Educação Especial em Salas Regulares. C\&DRevista Eletrônica da FAINOR, Vitória da Conquista, v.11, n.3, p.541-560, set./dez. 2018. Disponível em $<$ http://srv02.fainor.com.br/revista/index.php/memorias/article/viewFile/803/441. Acesso em 20 de jul. 2019.

BRASIL. Ministério da Educação. A Consolidação da Inclusão Escolar no Brasil. Disponível em <http://www.ufpb.br/cia/contents/manuais/a-consolidacaoda-inclusao-escolar-no-brasil-2003-a-2016.pdf/view>. Acesso em 24 jul. 2019.

UNESCO. (1994). Declaração de Salamanca: sobre princípios, políticas e práticas na área das necessidades educativas especiais. Salamanca, UNESCO. Disponível em < 
http://portal.mec.gov.br/seesp/arquivos/pdf/salamanca.pdf>. Acesso em 19 jul. 2019.

VARGAS, Rosanita Moschini; SCHMIDT, Carlo. Envolvimento parental e a inclusão de alunos com autismo. Acta Scientiarum: Education, 01 Março 2017, v.39, n. 2, p.207-217. Disponível em $<$ http://periodicos.uem.br/ojs/index.php/ActaSciEduc/article/view/26423>. Acesso em 5 jul. 2019. 


\section{ÍNDICE}

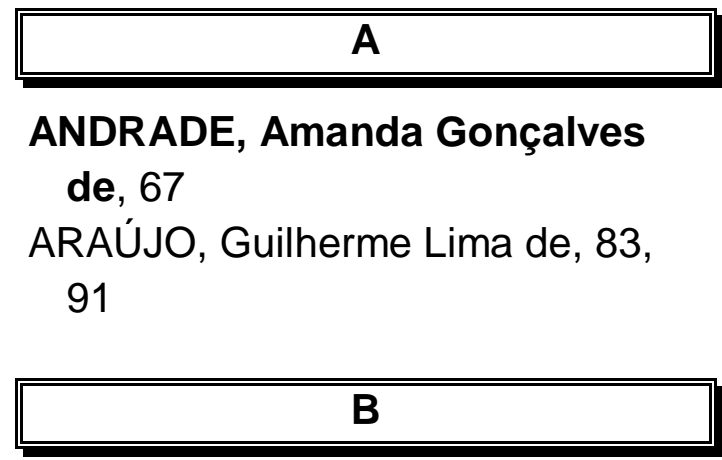

BARINI, Cristiane Rodrigues da Cunha, 156

BULGO, Danilo Cândido, 56

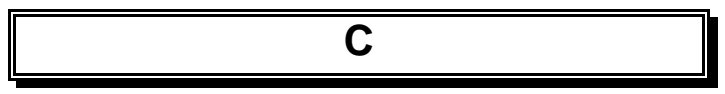

CAETANO, Jaqueline Silva, 9

CARRARO, Mariana, 145

CATANANTE, Flávia, 24

CUNHA, Luísa Alves Rodrigues da, 156

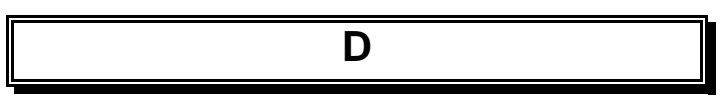

DEGRANDE, Pedro Alexandre F.

S., 100

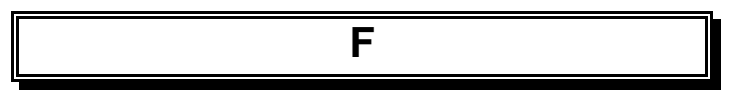

FERREIRA, Alessandra Freitas Lopes, 145

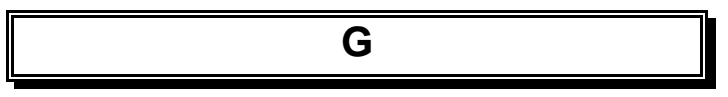

GALERANI, Thiago da Silva, 92

GIMENES, Priscila Alvarenga

Cardoso, 9, 135

GOMES, Eddara Santos, 34, 43

GONÇALVES, Cristian Ribeiro, 56

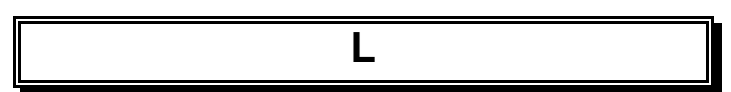

LOPES, Eduardo Matheus Ferreira, 100

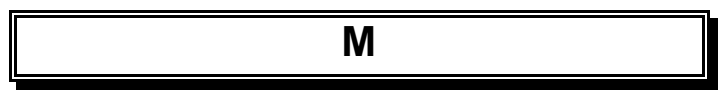

MARCICO, Bianca, 100

MARTINO, Vânia de Fátima, 67, 145

MOURA, Arthur de Lucca Veronez Galdiano, 135

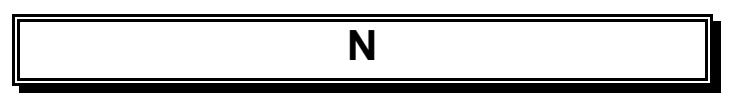

NASCIMENTO, Lilian Cristina Gomes do, 56

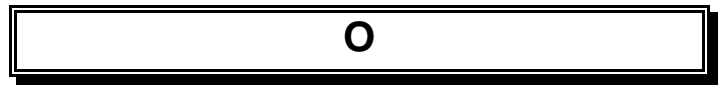

OLIVEIRA, Paulo de Tarso, 156

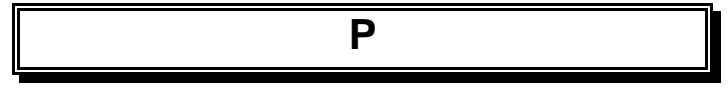

PEREIRA, Flávio Macarini, 109

PIANA, Maria Cristina, 34

\section{$\mathbf{R}$}

REIS, Graziela Donizetti dos, 24

\section{S}

SILVA, Aline Lima da, 24

SILVA, Juliano Aparecido da, 74

SILVA, Renan Antônio da, 123

SPINIELI, André Luiz Pereira, 45, 55 

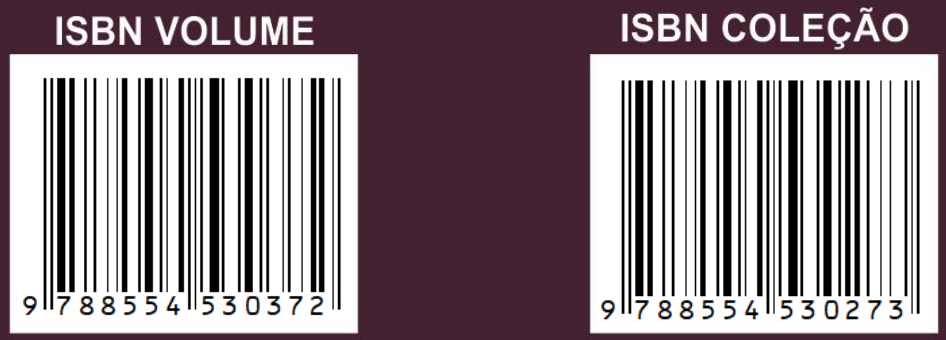

\section{8 | 163713.4688 unifacef.com.br | f}

163706.8700 franca.unesp.br 